Arlindo Jonas Fagundes Kohlrausch

\title{
Introdução à história da arquitetura de Ponta Grossa / Pr: As casas de madeira - 1920 a 1950
}

Dissertação de Mestrado

Comissão de pós-graduação da

Faculdade de Arquitetura da Universidade de São Paulo

Trabalho apresentado para a obtenção do título de mestre em arquitetura

Área de concentração - História da arquitetura e fundamentos do projeto Orientadora: Profa. Dra. Marlene Yurgel

São Paulo, 2007 
Autorizo a reprodução mecânica parcial dos conteúdos desta dissertação de mestrado para fins específicos de pesquisa acadêmica.

Ficha catalográfica:

Palavras-chave:

História da arquitetura do Paraná História da arquitetura de Ponta Grossa História da arquitetura da imigração Arquitetura de madeira no Paraná 
Errata: 
Dedico este trabalho a memória de meus pais

Henrique e Iolanda Kohlrausch 
Agradeço a Deus,

A minha orientadora Marlene Yurgel

Aos professores e funcionários da FAU

e todos que colaboraram na realização deste trabalho. 
Resumo:

Essa pesquisa de mestrado visa a documentação de um período significativo da história da arquitetura de Ponta Grossa, Paraná: as casas de madeira. A cidade tem seu desenvolvimento acelerado no final do século XIX, como ciclo econômico da madeira, a chegada da ferrovia e da imigração. A pesquisa busca identificar as influências dos principais grupos de imigração: alemães, poloneses, ucranianos e italianos, e o processo de configuração da arquitetura de madeira na cidade, demonstrado através de projetos aprovados na prefeitura, entre as décadas de 1920 até 1950.

\section{Abstract:}

This research of master degree seek to document a significative period of the history of the architecture of Ponta Grossa, Paraná: the wood houses. The city had an increase of it's development at the end of XIX century, at the economic cycle of wood, with the arrival of the rail network and the immigration. The research seek to identify the influences of main immigration groups: germans, polishs, Ukrainians and Italians, and the configuration process of the wood's architecture in the city, demonstrated through the approved projects in the city hall, between the decades of 1920 until 1950. 
SUMÁRIO

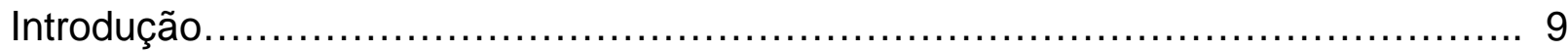

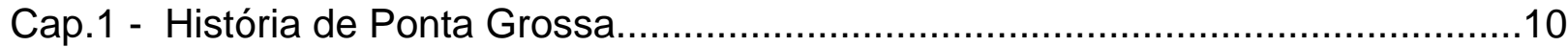

Cap. 2 - Os ciclos econômicos.............................................................................

Cap. 3 - A formação da arquitetura da madeira em Ponta Grossa...............................24

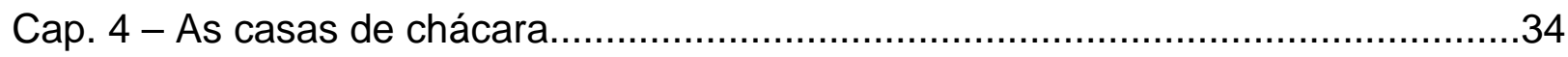

Cap. 5 - Catalogação de projetos aprovados na prefeitura de Ponta Grossa..............42

Cap 6 - Levantamento de exemplares de casas de madeira existentes....................172 Na cidade de Ponta Grossa em 2006.

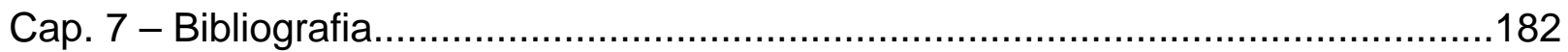


INTRODUÇÃO

A cidade de Ponta Grossa, fundada por fazendeiros e tropeiros, tem o auge se seu processo de urbanização com a chegada da ferrovia e da industria da madeira, que vem influenciar desde o desenho urbano da cidade, seu modo de vida relacionado ao transporte, e a caracterização de sua arquitetura. A madeira surge como uma opção natural integrada aos estilos acadêmicos europeus do ecletismo e de suas variantes naturalistas: o chalé e o bangalô. A paisagem urbana da cidade no início do século XXI é de um rico mosaico de miscigenação cultural, emoldurado pelas visuais de suas ruas de topografia acidentada, onde se justapõe edificações de origens diversas com o fundo de matizes verdes dos campos gerais. 
Capítulo 1

\section{História de Ponta Grossa}

A história da arquitetura de Ponta Grossa tem dois aspectos fundamentais em sua localização geográfica e no seu processo histórico de desenvolvimento. A cidade se localiza no segundo planalto paranaense, na região dos Campos Gerais, formada por suaves colinas ponteadas por riachos de pedra e matas de araucária, de beleza cênica notável. O clima é subtropical úmido-mesotérmico, de verões frescos, com a ocorrência de geadas severas e freqüentes, não apresentando estação seca. A altitude é entre 900 e 1.000 metros, e as coordenadas geográficas são $25^{\circ}$. $05^{\prime} 58^{\prime \prime}$ sul e $50^{\circ}$. $09^{\prime} 30^{\prime \prime}$ oeste. Particularmente interessante para nossos estudos é a localização da escarpa devoniana no lado nordeste do atual município, que nos registros históricos é conhecido como Itambé, que constitui um paredão de arenito de mais de trezentos metros de altura que vem da região de Curitiba e São Luiz do Purunã em direção a Castro. Esta escarpa surgiu nos movimentos tectônicos continentais e constitui o divisor entre o primeiro e o segundo planaltos paranaenses e o divisor das bacias hidrográficas dos rios da Ribeira que correm para o litoral, e dos rios Verde, Pitangui e Tibagi, afluentes da bacia do rio Paraná. A região de Itaiacoca, comprimida pela ação tectônica abaixo do paredão do Itambé é de topografia acentuadamente dobrada, com solo turfoso, coberto de densa floresta, formando uma das maiores reservas de talco do planeta, enquanto a região acima do Itambé contrasta em campos de planícies.

As primeiras incursões da civilização européia que se tem notícia na região foram as das bandeiras paulistas de Aleixo Garcia em 1526 e de Pedro Lobo em 1531. Em 1541 Álvaro Nunes Cabeza de Vaca, "adelantado" espanhol em Assunção, cruzou os campos gerais, fundando a Vila do Príncipe, atual cidade da Lapa, marco histórico da região. Em 1552 Ulrich Schmiedel faz o sentido inverso, vindo de Assunção com destino a São Vicente, acompanhado de quatro soldados alemães e vinte índios paraguaios.

A povoação do Paraná começa quando moradores de São Vicente descem o litoral e fundam Paranaguá nos anos 1630, motivados pela descoberta de ouro, que mesmo em pequena quantidade, realizou a fundação de pequenos assentamentos nas encostas da Serra do Mar que desenvolveram as cidades de Antonina, Morretes e Curitiba em 1668.

Os padres da Companhia de Jesus tiveram um papel importante na ocupação da região pelo processo de catequização através das missões evangelizadoras, logo após transformadas em reduções. Em 1588 os religiosos Fields e Manoel Ortega da Companhia de Jesus, desembarcaram em Paranaguá e atravessaram o Paraná em direção ao 
Paraguai, para a catequese dos índios. Fundaram 13 reduções na bacia do rio Tibagi. No século XVII constroem um convento e um colégio em Paranaguá, e dali abrem caminho para o primeiro planalto de Curitiba e para o interior.

A descoberta de ouro nas Minas Gerais influencia os destinos da região. Por razões estratégicas, um decreto da Coroa Portuguesa em 1704 proíbe a abertura de vias de circulação das Minas em direção ao norte e Bahia, e determina que todo o suprimento de gado de corte e muares para transporte venha das capitanias do sul. Nessas épocas, essas terras faziam parte da $5^{\mathrm{a}}$. comarca de São Paulo, começaram a despertar o interesse dos paulistas para a criação de gado. As terras eram requeridas e doadas pela Coroa em sistema de Sesmarias.

Conforme o relato do historiador José Carlos da Veiga Lopes sobre uma das primeiras sesmarias da região:

"No dia 19 de março de 1704, o governador do Rio de Janeiro, D. Álvaro da Silveira e Albuquerque expediu um alvará de sesmaria ao capitão-mor Pedro Taques de Almeida e familiares (...) todos moradores na vila de São Paulo, que haviam solicitado as terras sitas no caminho que ia para a vila de Curitiba, termo e distrito da capitania da Conceição, que começariam desde Jaguaricatu até o rio lapó, que seriam sete ou oito léguas mais ou menos, campo e terra lavradia, e do dito rio lapó até Itaimbé, uma e outra banda do caminho, que poderiam ser doze até quatorze léguas, tudo campos gerais para criar gado, com pouca terra lavradia, com algumas restingas e capões para lavrar os curraleiros e madeira para currais, ficando em meio o caminho que ia da vila de Sorocaba para a dita vila de Curitiba. (...) E o governador houve por bem fazer mercê (em nome de sua majestade, que Deus guardasse) de doar aos suplicantes três léguas de terras de comprido e uma de largo, em consideração ao requerimento que lhe fizeram e sem prejuízo de terceiros, na forma da ordem de sua majestade em que dava providência a essas terras, entrando no distrito delas a paragem chamada lapó, não prejudicando a direito que algumas pessoas possuíssem e entre eles e as mesmas terras ficariam terras com baldios para sustento dos gados e seriam obrigados os suplicantes a fazer um curral de gado, dentro de dois até três anos para que houvesse abundância, tudo em cumprimento às ordens de Sua Majestade de 14 de março de 1702 e 7 de maio de 1703. (... na conclusão está dito que deram ao capitão-mor Pedro Taques e mais pessoas nomeadas, três léguas de terras de comprido e uma légua de largo, que começariam no distrito chamado lapó, não compreendendo minas nem vieiros). (Lopes, pg 06).

A seguir a região é dividida em grandes sesmarias. As terras eram doadas pela coroa com o compromisso explícito de construção de currais para a criação de gado. Na década de 1720 é formado o Caminho de Viamão, que ligava as regiões do extremo sul, até a feira de Sorocaba, onde eram realizadas as grandes feiras de comercialização, passando na região de Ponta Grossa, a montante da escarpa do Itambé. Esse caminho, também conhecido por Caminho das Tropas, foi oficialmente chamado de Estrada Geral do Continente Sul. Daí 
surgiram mais tarde inúmeras cidades, Itapetininga, Itapeva, Itararé, Jaguariaíva, Piraí do Sul, Porto Amazonas, Lapa e Rio Negro, constituindo a verdadeira espinha dorsal da ocupação do sul brasileiro. Neste caminho, na região da atual Ponta Grossa, os jesuítas haviam construído a Capela de Santa Bárbara, na fazenda Pitangui, próximo ao Pouso do lapó, atual Castro. Em seguida os fazendeiros construíram a Casa de Telha, um abrigo para atrair os tropeiros, próximo ao arroio do Lajeado Grande, atual vila Tânia Mara, que se constitui em marco da fundação do povoamento.

Segundo o historiador Brasil Pinheiro Machado entre 1725 e 1744 são requeridas mais de 90 sesmarias na região dos campos gerais. Na relação de fazendas de 1772 , em toda a extensão de Itararé no norte até a Lapa no sul, tendo como eixo a estrada das tropas, havia 50 grandes fazendas e 125 sítios. Ponta Grossa, Palmeira, Castro, Imbituva, Lapa, destacavam-se como povoações.

Em 1750 foi assinado entre Portugal e Espanha o Tratado de Madrid, que legitima as conquistas territoriais portuguesas e incentiva a expansão para o oeste, sendo registradas pelo menos onze entradas oficiais para os campos de Guarapuava nos vinte anos seguintes. Em 1765 assume o governo da capitania de São Paulo D. Luís Antonio de Souza Botelho Mourão, que manda elaborar vários recenseamentos da população e incentiva a expansão a oeste do estado, estabelecendo pontos de povoamento e formação de roças, abastecimento e manutenção militar. Nesse processo surgiu um novo caminho, passando pela Ponta Grossa, Carrapatos, Santa Cruz, Lago e Ferrador e ia ao Registro, atual cidade de Rio Negro, que passou a ser o preferido das tropas. 


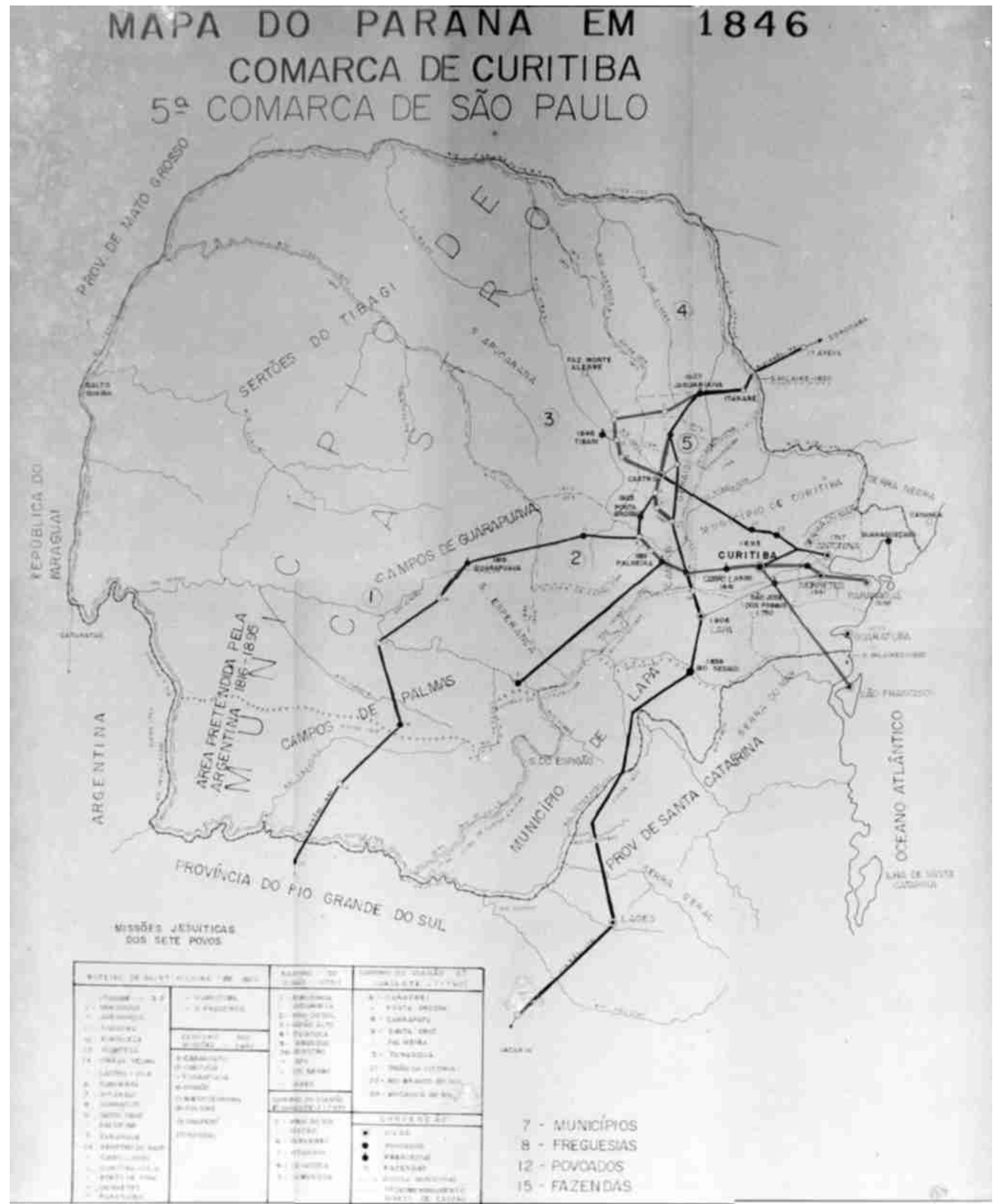

Mapa da região em 1846

Fonte: Casa da Memória 
A 27 de janeiro de 1770 o pouso do lapó (Castro), que na época era o pólo da região, foi elevado à freguesia com o nome de Santa Ana do lapó, fazendo divisa ao sul com Curitiba pelo rio Tibagi. Sant'Ana, que posteriormente viria a ser a padroeira também de Ponta Grossa, vem de uma tradição popular européia de proteção às famílias.

Vejamos a narrativa do historiador Veiga Lopes:

"A preocupação de D. Luis com os castelhanos era procedente. No dia 20 de janeiro de 1777 D. Pedro de Ceballos invadiu Santa Catarina. O governo de Sãp Paulo resolveu mandar um exército de 6.000 homens para acudir, e no dia 14 de maio a câmara da vila de Curitiba recebeu a obrigação de abastecer com alimentos, animais e condutores aos soldados, tendo sido entregue a relação de pousos onde seriam entregues as requisições. O caminho a ser utilizado era o antigo, Jaguariaíva, Cinzas, Furnas, lapó, Carambeí, Pitangui, Itaiacoca, Porcos, São Luis, Registro e Santo Antonio da Lapa. Em cada pouso havia pessoas responsáveis pelo recebimento. No Pitangui seriam recebidos 250 alqueires de milho, 75 de farinha, uma quarta de sal, 40 animais arriados de cangalhas e oito pessoas para arrieiros e em Itaiacoca250 alqueires de milho e 75 de farinha. A câmara de Curitiba protestou, alegando pobreza da região. O que salvou foi o tratado de Santo Ildefonso, de outubro de 1777. (Lopes, pg 46)

Em 1808, já com a corte de D. João VI no Rio de Janeiro, duas cartas régias dirigiam a questão. A de 5/11/1808, oferecia estímulos, inclusive sesmarias a quem se dedicasse em conquistar em definitivo os Campos Gerais e de Guarapuava, e a de 25/11/1808, permitia a concessão de sesmarias para estrangeiros residentes no Brasil 


\section{O SÉCULO XIX}

A INDEPENDÊNCIA DO BRASIL E O PERÍODO IMPERIAL

A ELEVAÇÃO DE PONTA GROSSA À FREGUESIA, VILA E CIDADE A IMIGRAÇÃO EUROPÉIA

\section{A FERROVIA}

As transformações políticas nacionais do século XIX se refletem diretamente na história de Ponta Grossa, devido a sua inserção na economia do caminho das tropas. No início do século, o pouso do lapó era a sede administrativa da região e estava em franco desenvolvimento, com comércio movimentado para os padrões da época.

Em 1810 o bairro obteve autorização do bispo de São Paulo para a realização de missas, batizados, casamentos e sepultamentos em uma pequena capela e cemitério que foram construídos ao lado do caminho das tropas, onde se localiza hoje a praça Barão de Guaraúna, centro da cidade. O povoamento se desenvolveu nesse local, com as primeiras casas com pequenas roças e a produção de artesanatos simples de cestas, balaios, chapéus de palha, baixeiros, coxinilhos, arreios de couro crú, renda de bilro, mantos de tear, que eram levados pelos tropeiros para serem vendidos em Sorocaba. Próximo ao alto da colina da atual matriz já existia um comércio de produtos trazidos de São Paulo em lombo de burro, uma ferraria e uma pequena venda.

$\mathrm{Na}$ década de 1810 os fazendeiros locais solicitaram a elevação do bairro para freguesia. Com isso teriam maior autonomia, e se evitariam os deslocamentos até Castro, distante sete léguas, aproximadamente 46,2 quilômetros (cada légua de sesmaria é de aproximadamente $6.600 \mathrm{~m}$ ). Para que o pedido fosse atendido era necessário provar: existir um número suficiente de moradores no bairro; a existência de uma capela paramentada; a fixação da côngrua ao pároco; justificar a distância do bairro aos recursos espirituais mais próximos. Para capela foi reutilizada a Casa de Telha, que estava abandonada desde que os jesuítas deixaram a região. Em 15/9/1823 o povoado obtém a condição de freguesia, com o nome de Estrela, que seria substituído para Ponta Grossa.

O local escolhido para a construção da capela definitiva segue a tradição das cidades portuguesas, na colina mais alta da região, onde já existia uma cruz de madeira, oratório dos tropeiros, atual praça da matriz. A primeira capela foi construída em tábuas de pinho, por um carpinteiro de São Paulo, Jerônimo Vieira, que ficou na cidade e construiu mais tarde a matriz de Sant'Ana, no mesmo local. Nessa época existiam os bairros de Carrapatos, Conchas, Taquarussu, São José, Santo Amaro e Itaiacoca.

Segundo o historiador Ruy Wachowicz,em sua obra História do Paraná (2001), em 1820 as casas de Castro eram de pau a pique. $\mathrm{Na}$ Lapa, as primeiras casas de alvenaria surgiram em 1824. Mas em 1844 algumas casas de Palmeira, Ponta Grossa e Castro eram de pedra e cal. 
Vejamos o quadro da distribuição da população:

(fonte: Ponta Grossa, Um Século de Vida, pg. 74)

$\begin{array}{lccc}\text { Anos } & \text { livres } & \text { escravos } & \text { total } \\ & & & \\ 1824 & 1.330 & 331 & 1.661 \\ 1825 & 1.266 & 297 & 1.563 \\ 1830 & 1.578 & 379 & 1.957 \\ 1832 & 2.082 & 476 & 2.558 \\ 1835 & 1.734 & 516 & 2.250 \\ 1854 & 1.974 & 1.059 & 3.033 \\ 1870 & 5.581 & 909 & 6.490 \\ 1890 & & & 4.774 \\ 1900 & & & 8.335 \\ 1920 & & & \end{array}$

Mesmo com a elevação à freguesia, Ponta Grossa continuava vinculada a Castro. Em 1842 Ponta Grossa participava com $22 \%$ da população da $5^{\mathrm{a}}$. Comarca, com 3.000 habitantes dos 14.000 totais, distribuídos nas ocupações de proprietários, negociantes, lavradores, tropeiros, capitalistas, empregados na fabricação de erva mate e escravos. No Registro de Guias de Comércio de gado de Rio Negro, de 1847 a 1852, Castro contava com 22\% de participação, Lapa 14\% e Ponta Grossa com 9\% dos totais de passagem.

No tropeirismo existe a prática da "invernagem" que é uma época em que a tropa descansa para a engorda. Existiam campos públicos chamados "reúnos", que serviam para essa prática, mas que foram sendo privatizados, além dos campos particulares que eram alugados. A invernagem se intensifica na região nos anos 1860, chegando a formar uma pequena feira nos anos 1870. Até a década de 1920, Ponta Grossa é o principal entreposto do comércio de gado no interior do Paraná. 


\section{A INDUSTRIALIZAÇÃO}

Nos anos 1850 havia também o comércio de erva mate para Curitiba e litoral, além de uma pequena produção de coxonilhos e baixeiros para São Paulo. A agricultura não era desenvolvida, por ser mais dificultosa e menos lucrativa. Do Rio de Janeiro e de São Paulo eram trazidos sal, farinha de trigo, ferragens, tecidos, bebidas e outros. A erva mate se torna o principal produto da economia local. (Gonçalves, 1983) Em Ponta Grossa se fabricava a erva mate em rama, que era enviada em cargueiros para Curitiba, Antonina e Morretes.

Nesse ano, Miguel Ferreira da Rocha Carvalhaes requereu uma comissão para examinar um engenho de madeira, na fazenda Bom Sucesso de sua propriedade. A comissão descreve a inovação que: "possui serra horizontal servindo na mesma máquina várias serras de diferentes graduações para serrar tábuas de diferentes espessuras." O engenho possuía também casa de máquinas, moradias e senzalas, e depósito de madeira serrada.

Em 1852 foi concluída a construção da igreja matriz em pedra e cal, no sistema de paredes de estuque. Foi iniciada a construção da capela do Rosário, também em pedra e cal, no estilo colonial jesuítico, próxima a uma grande barroca, que é hoje a praça Barão do Rio Branco.

Com a elevação da $5^{a}$. Comarca de São Paulo à categoria de Província do Paraná em 19/12/1853, os pontagrossenses requisitaram a elevação da freguesia à vila. Contava com 6 vendas de tecidos, 9 armazéns de secos e molhados e 3 açougues. Em 7/4/1855, Ponta Grossa é elevada à categoria de Vila pela Lei Provincial 54. Contava com 3.033 habitantes, sendo 1059 escravos, Eram 16 fazendas, 343 sítios de lavoura, 3 engenhos de erva-mate, e 650 "fogos" (casas) distribuídos em 17 quarteirôes.

Em 24/3/1862, a Lei Provincial 82 elevou a Vila à categoria de Cidade. Em 18 de abril de 1876 é declarada sede de comarca, sendo o primeiro juiz o Dr. Conrado Ericksen.

Na década de 1860 inicia o processo de concentração urbana em oposição à dispersão rural, com as atividades de comércio e produção de erva-mate, beneficiamento de madeira, além da criação de gado e dos equipamentos característicos dessa atividade. Surgem as primeiras profissões liberais de advogados. médicos e oleiros. Em 1855 surgiu a primeira olaria no bairro da Ronda, embora a região de Olarias se tornasse o primeiro bairro de características de produção industrial, com a instalação de várias olarias e curtumes. Em 1869 a Câmara concedeu licença a três médicos formados, sendo que anteriormente havia um homeopata. Nesse ano foi inaugurado o edifício próprio da Câmara Municipal, construído em técnica de pedra e cal, através de contribuições de populares. Nessa época o movimento das casas comerciais solicitava a presença de um banco. Em 1873 foi construído o primeiro teatro, em 1876 a primeira biblioteca, e em 1906 o primeiro cinema, denominado Recreio, localizado na rua Sete de Setembro. Em 1911 veio o Cine e Teatro Renascença, depois Inajá, na esquina com a rua XV. A historiadora Maria Aparecida Gonçalves, em seu livro Ponta Grossa, um século de vida, cita a construção da igreja matriz sob a responsabilidade do arquiteto Nicolau Ferigotti Buhnemann, provavelmente uma das 
primeiras intervenções da profissão na cidade. Atualmente é nome de rua, prolongamento da Teixeira Mendes em Uvaranas.

Em 1890, Ponta Grossa contava com 4.774 habitantes, distribuídos em uma planta de 30 ruas e travessas, limitava-se ao norte pela praça Barão do Rio Branco e Barão de Guaraúna, sendo a rua mais extensa a rua das Tropas; o centro era formado pela praça da matriz e pelo Largo da Cadeia, lembrando que o atual colégio Senador Correia foi construído sobre uma praça, que formava uma marcante estrutura urbana com as laterais da antiga catedral, a praça Floriano Peixoto, a rua dos bancos, XV de Novembro e posteriormente a rua do comércio, Vicente Machado. Em 1890 as lojas mais importantes eram a Casa Juca Pedro na rua Sant'Ana; a casa Vilela na Sete de Setembro; e a casa Estrela na praça da Matriz.

A primeira rede de água e esgoto é inaugurada em 1912, com recursos do governo da Província. Nesse ano é inaugurado o primeiro hospital da cidade, Santa Casa de Misericórdia, sendo que antes o único atendimento era uma enfermaria da Rede Ferroviária Paraná - Rio Grande, inaugurada em 1902. Em 1923 a cidade já possuía calçamento no centro, telefone, água e esgoto, hospitais. Era notória a participação das bandas musicais, dos clubes recreativos e literários, dos grupos de teatro e do cinema, e a prosperidade do comércio. 
Capítulo 2

\section{OS CICLOS ECONÔMICOS}

Enquanto a Europa vivia as profundas transformações econômicas e sociais da revolução industrial do século XIX, o imperador Pedro II procurava um realizar um projeto de desenvolvimento para o país. As estatísticas apontam que entre 1820 e 1950 entraram no Brasil cerca de cinco milhões de imigrantes.

A partir de 1850 inicia um processo de imigração na região de Ponta Grossa que trouxe novas populações de diferentes nacionalidades: alemães, poloneses, ucranianos, italianos, russos, árabes, japoneses, entre outros, realizando uma forte diversidade cultural.

A imigração tinha como objetivo integrar o excedente de mão de obra que estava acontecendo na Europa no processo de industrialização e urbanização que se iniciava no novo país. Vários fatores se complementam para realizar o processo de desenvolvimento na região: a construção da ferrovia; a exploração da erva mate; a exploração da madeira; o surgimento de um pólo de comércio regional. O elemento humano que conduziria esse processo seria os imigrantes.

Em 1880 é construído o primeiro engenho com 12 pilões. A produção em ramas era de excelente qualidade e se torna o principal produto da economia. (nota - livro um séc - pg 48) Era enviada para as cidades de Curitiba, Antonina, Morretes e exportada para Montevideo e Buenos Aires. No começo do século existiam sete estabelecimentos no ramo, alguns simples entrepostos. A firma Santos Ribas com filial em Curitiba, exportou 10.000 toneladas de erva mate nos anos 1919 e 1920. (Gonçalves, 1983)

A inauguração da ferrovia em 1894, muda totalmente as características da cidade que passa a ser a convergência de seis grandes linhas nacionais, com centrais de entroncamento, transferência de mercadorias, oficinas e escolas de manutenção. A cidade passa por intenso processo de desenvolvimento, tornando-se centro comercial do sul do país. 


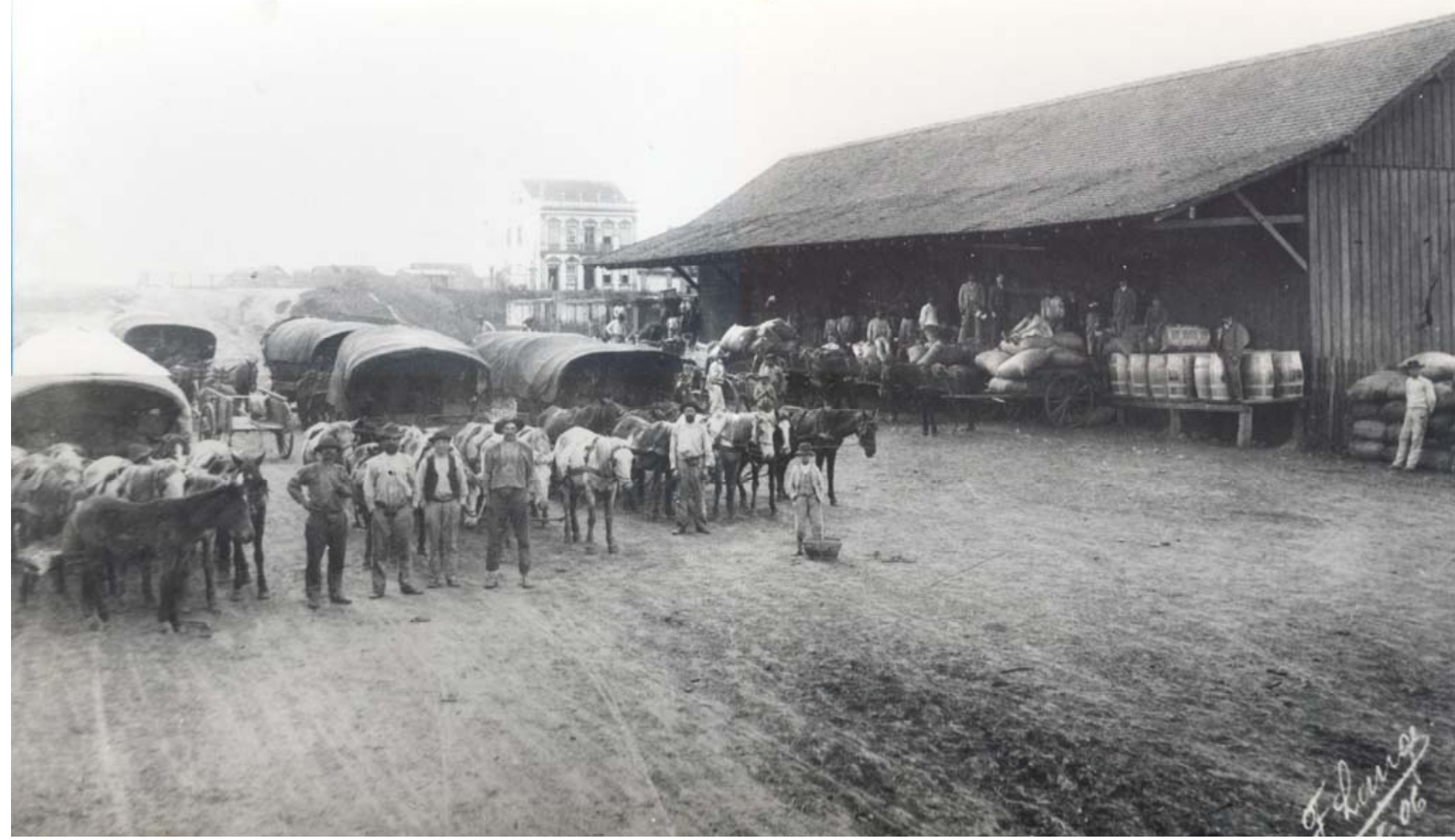

Armazéns da rede ferroviária em Ponta Grossa, ano de 1906.

Fonte: Casa da Memória

A história da ferrovia está vinculada com o ciclo da madeira, ocorrido no estado do Paraná e Santa Catarina. Muitas cidades desses estados foram construídas com os recursos e a matéria prima do pinheiro araucária.

Em 1906 foi fundada a serraria Olinda, com desvio próprio junto ao pátio da rede, com locomóvel de 60 cavalos e instalações completas para o corte, beneficiamento da madeira e fabricação de caixas. Essa empresa foi a origem das empresas Kluppel, que desenvolveram a produção de equipamentos para serraria, assim como as empresas Schiffer no bairro de Nova-Rússia, que além de equipamentos para serraria especializaram na construção de chassis e carrocerias para caminhões. Essas empresas iniciaram a formação de um parque industrial metal mecânico na cidade.

O ciclo da madeira no Paraná foi de intensa produção, determinando inclusive a configuração urbana da cidade pela implantação de grandes serrarias próximas da via férrea. Como exemplo citamos que em 1922 havia serrarias em Ponta Grossa que exportavam 24 vagões de carga por mês com estoque permanente para 150 vagões. O ciclo da madeira implantou na cidade grandes serrarias,dentre as quais as industrias Wagner produziam chapas de compensado em grande escala. A exploração da madeira de araucária decai na metade do século, sendo substituído pelos reflorestamentos de pinus elliotis, cujo aproveitamento para a construção foi amplamente debatido no Fórum 
Madeireiro da Assembléia Legislativa do Paraná, em agosto de 1993, demonstrando amplas possibilidades de desenvolvimento para o setor.

Na década de 1970 o PLADEI, Plano de Desenvolvimento Industrial, consolidou a cidade como pólo de beneficiamento de soja, recebendo para transformação a produção dos estados do Paraná, Mato Grosso, interior de São Paulo e do Paraguai, para a exportação pelo porto de Paranaguá. Ponta Grossa é hoje um dos pontos onde se faz a cotação do preço deste produto para as bolsas de valores internacionais.

No ano de 2007 os dividendos da madeira suplantam os da soja no valor das exportações realizadas pela cidade, sendo novamente o produto de liderança da economia regional. Atualmente a cidade conta com 300.000 habitantes, se consolida no setor de prestação de serviços com uma universidade estadual e quatro particulares, além dos setores correlatos.

\section{A IMIGRAÇÃO NOS CAMPOS GERAIS}

O ciclo econômico do tropeirismo caracterizado por um modo de vida campesino, entra em declínio a partir dos anos 1870, para ser substituído por um sistema econômico mais dinâmico, baseado na industrialização e no modo de vida urbano.

Enquanto na Europa do século XIX, um vertiginoso crescimento da população de trabalhadores de atividades agrícolas e urbanas, formaria as grandes correntes migratórias para o novo mundo até a metade do século XX.

A imigração no Brasil está relacionada com a substituição do trabalho escravo que culmina com a Lei da Abolição em 1888, e se desenvolve conforme as diferentes realidades econômicas e sociais de cada região.

A imigração no Paraná se dá com objetivos específicos. Primeiro de ocupação do território, segundo de criar uma rede de abastecimento de alimentos para as cidades existentes, pois 
a atividade agrícola era escassa, devido à forte atração da atividade pecuária e depois a ervateira, ocorrendo crises de abastecimento alimentício.

Assim, atraídos pelas oportunidades oferecidas pelo "novo mundo", e pelas características geográficas assemelhadas com a sua terra natal, vieram os imigrantes europeus. A partir da década de 1870, o governo da província acelerou os assentamentos de colônias próximas das cidades já existentes: Curitiba, Campo Largo, Lapa, Rio Negro, Palmeira, Ponta Grossa, Castro, Paranaguá, Morretes, Antonina, São João do Triunfo, Porto de Cima. A partir dos anos 1930, empresas de colonização realizaram assentamentos de imigrantes no estado, com a fundação de cidades planejadas como Londrina, Maringá, Cianorte.

Estas foram as primeiras colônias implantadas no Paraná:

Em 1829 é fundado o núcleo de colonização alemã em Rio Negro, no sul do estado, pelo barão de Antonina.

Em 1833 chegam em Curitiba os primeiros imigrantes alemães vindos da Colônia Francisca (atual Joinvile) e de Rio Negro, para trabalhar em chácaras de abastecimento agrícola da capital.

Em 1847 é criado o núcleo Colônia Tereza, de imigrantes franceses, pelo médico Jean Maurice Faivre, no sertão do Ivaí, 20 léguas $(132 \mathrm{~km})$ a oeste de Ponta Grossa, que devido ao isolamento, não progrediu.

Em 1852 é fundada a colônia Superagui, hoje Guaraqueçaba, na baía de Paranaguá. Em 1860 é fundada a colônia Assunguy, hoje Cerro Azul e em 1869 a colônia Argelina, hoje bairro do Portão em Curitiba. Em 1874 é fundada uma colônia em Paranaguá.

A partir da década de 1870 o processo de imigração se intensifica com a implantação de colônias em todo o estado, com a política de localização próxima dos centros urbanos. Nos anos 1870 são estabelecidas 26 colônias no Paraná, 19 na região de capital. Na década de 1880 são estabelecidas15, na década de 1890 são estabelecidas 19 colônias e na década de 1900 são implantadas mais 10 colônias no estado. São localizadas inicialmente próximas das cidades já existentes: Curitiba, Campo Largo, Lapa, Rio Negro, Palmeira, Ponta Grossa, Castro, Paranaguá, Morretes, Antonina, São João do Triunfo, Porto de Cima. 
A primeira colônia fundada em Ponta Grossa é a colônia Otavio, em 1878, de alemães do Volga, seguindo-se as colônias de Guarauna, Guarauninha, Taquary, Rio Verde, Eurídice, Trindade, Dona Adelaide, Botuquara, Tavares Bastos, Floresta, Itaiacoca, Moema e Tibagi, perfazendo um total de 975 assentados de nacionalidades alemã, polonesa, italiana, russa e brasileira.

A partir dos anos 1930, empresas de colonização realizaram assentamentos de imigrantes no estado, com a fundação de cidades planejadas como Londrina, Maringá, ----especificar-$--$ 
Capítulo 3

\section{A FORMAÇÃO DA ARQUITETURA DE MADEIRA DE PONTA GROSSA}

Para compreendermos a formação da arquitetura de madeira na região é necessário utilizarmos o conceito de miscigenação.

As técnicas construtivas são resultado de um longo processo de formação dentro da história universal, onde os contatos e as trocas culturais contribuem para um desenvolvimento conjunto.

A imigração propiciou a vinda de diversas culturas de construção, que interagiram num rico processo de trocas, de maneira difusa, cuja compreensão é fundamental para o estudo da história de nossa arquitetura.

A principal determinante para a arquitetura de madeira no Paraná é a existência de extensas áreas florestais, onde se destaca o pinheiro, utilizado em larga escala, desde os primeiros estágios da colonização, a partir de tecnologias rudimentares, até a sua difusão industrial no ciclo econômico da madeira.

\section{A arquitetura de madeira na época do tropeirismo.}

A fundação da cidade tem a influência da arquitetura colonial portuguesa. As capelas dos jesuítas de Santa Bárbara (1730). Santa Luzia e Nossa Senhoras das Pedras, na rota dos tropeiros, junto ao paredão do Itambé, são construídas na técnica da pedra e cal. As sedes das fazendas, como a fazenda Capão Alto, utilizavam a técnica de origem portuguesa da taipa de pilão, com o uso simultâneo da madeira em construções anexas ou mesmo partes das construções principais. 
Vejamos o relatório de tombamento desta fazenda, pela Secretaria de Estado da Cultura:

..."Algumas das edificações - entre elas o casarão central - foram levantadas em taipa de pilão, e constituem, provavelmente, os únicos exemplares desta antiga técnica de construção ainda existentes no Paraná. As demais construções, ao fundo do casarão, são de alvenaria de tijolos e madeira, datando, ao que tudo indica, da época em que a fazenda de gado de corte passou a abrigar gado leiteiro".

Interessante observar o relato da historiadora Guisla Chamma sobre as fazendas do tropeirismo na região, no texto "A sociedade campesina nas grandes fazendas dos campos gerais":

"Era uma vida muito simples, daqueles que moravam nas fazendas dos campos gerais.

O proprietário morava numa casa grande, construída de tábuas de pinho, com a junção das mesmas tapadas por ripas mais estreitas, a fim de vedar a passagem do vento.

As janelas e portas fechadas por uma só peça de madeira, com tranca também de madeira. Não havia vidraças. Na maioria das vezes, as dobradiças eram feitas de couro.

Construíam uma varanda na frente da casa, que às vezes se prolongava para os lados. Só no século XIX é que começaram a cobrir suas casas com telhas trazidas de Paranaguá, no lombo de burros. Eram fabricadas em São Paulo.

Assim mesmo o número de casas cobertas de tabuinhas era muito grande, pois as telhas só podiam ser compradas por gente de muito dinheiro.

Além da casa grande do fazendeiro, algumas outras casas eram construídas para abrigar o pessoal que morava na fazenda.

Uma casa comprida e estreita, sem assoalho, era a senzala.

Aqui no sul, os fazendeiros preferiam fazer a senzala separada da casa grande, ao invés de usar às vezes o porão, para abrigar os escravos, como era o costume de alguns fazendeiros de São Paulo e do Rio de Janeiro.

Na senzala, a uma certa altura do teto, aproveitavam para estender um ripado onde era armazenada a alfafa, capim, milho no sabugo, etc.

Os escravos ocupavam a parte de baixo, numa altura que dava mal e mal para caminhar ereto.

A construção internamente era dividida por tábuas em cubículos de 1,50 X2,00m, onde dormia uma família escrava, pais e filhos, em total promiscuidade.

As outras casas pequenas, eram para o pessoal branco, que trabalhava na fazenda, mas que não fazia parte da família.

Vestiam roupas quase sempre tecidas na fazenda. O algodão vinha de Sorocaba, a lã para fiar do Rio Grande do Sul, trazida pelos tropeiros. O serviço de fiar, tecer e confeccionar o vestiário era trabalho feminino. Todas as mulheres da fazenda trabalhavam, inclusive a mulher e as filhas do fazendeiro. Os primeiros tempos eram difíceis todos tinham que ajudar. 
Na própria fazenda, além do trabalho de cuidar do gado, conduzi-lo às invernadas, marcar, domar, separar, colocar sal nos cochos espalhados pelo campo, havia ainda o trabalho de manutenção da fazenda. Quem mais trabalhava era o escravo.

Carpinteiros, seleiros, ferreiros, uma diversificação de tarefas pois tudo era feito ali.

Os toscos móveis usados nas casas, as cercas, os galpões, feitos com madeira da própria região: selas, arreios, embornais, sandálias, chapéus, com o couro curtido dos animais ali criados. Utensílios de ferro, como enxadas, facas, facões, machados. O ferro era trazido de Sorocaba em barras, e armazenado, para ser transformado em ferramenta no momento certo. 


\section{A arquitetura da madeira e a imigração}

Os povos de imigração européia de origem eslava: alemães, poloneses, ucranianos e russos, tinham tradição milenar de construções em madeira.

\section{A contribuição alemã}

Os alemães trouxeram a arquitetura enxaimel, largamente difundidas em suas colônias no sul do Brasil, Embora com poucos exemplares no Paraná, consideramos que contribuiu para o sistema construtivo das casas com estrutura de madeira, através dos processos de difusão cultural. Para estudos dessa arquitetura recomendamos a obra do arquiteto Gunter Weimer , "Arquitetura da Imigração Alem", e a obra "Arquitetura em Enxaimel" do historiador Wolfang Collischonn,

A colônia alemã da Terra Nova, fundada em 1933 a 40 km de Ponta Grossa se constitui de uma comunidade de imigrantes proprietários de pequenas fazendas com intensa produção agrícola e pecuária. As casas construídas na época da fundação da colônia expressam a herança cultural dos povos imigrantes. 


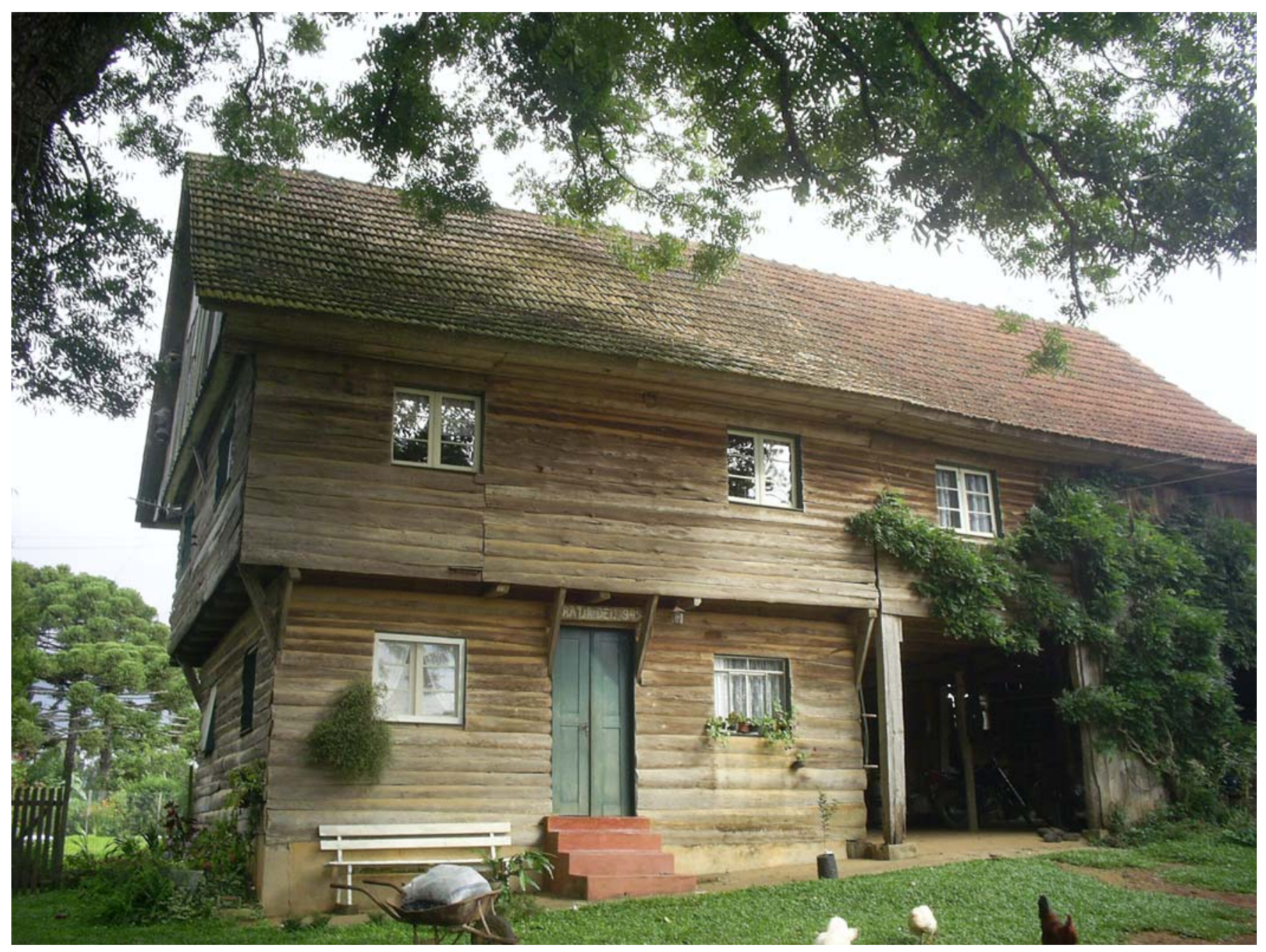

Casa da fam[ilia Maus, construída na colônia Terra Nova em 1934, com paredes duplas de tábuas e costaneiras. Foto AK, 2007. 


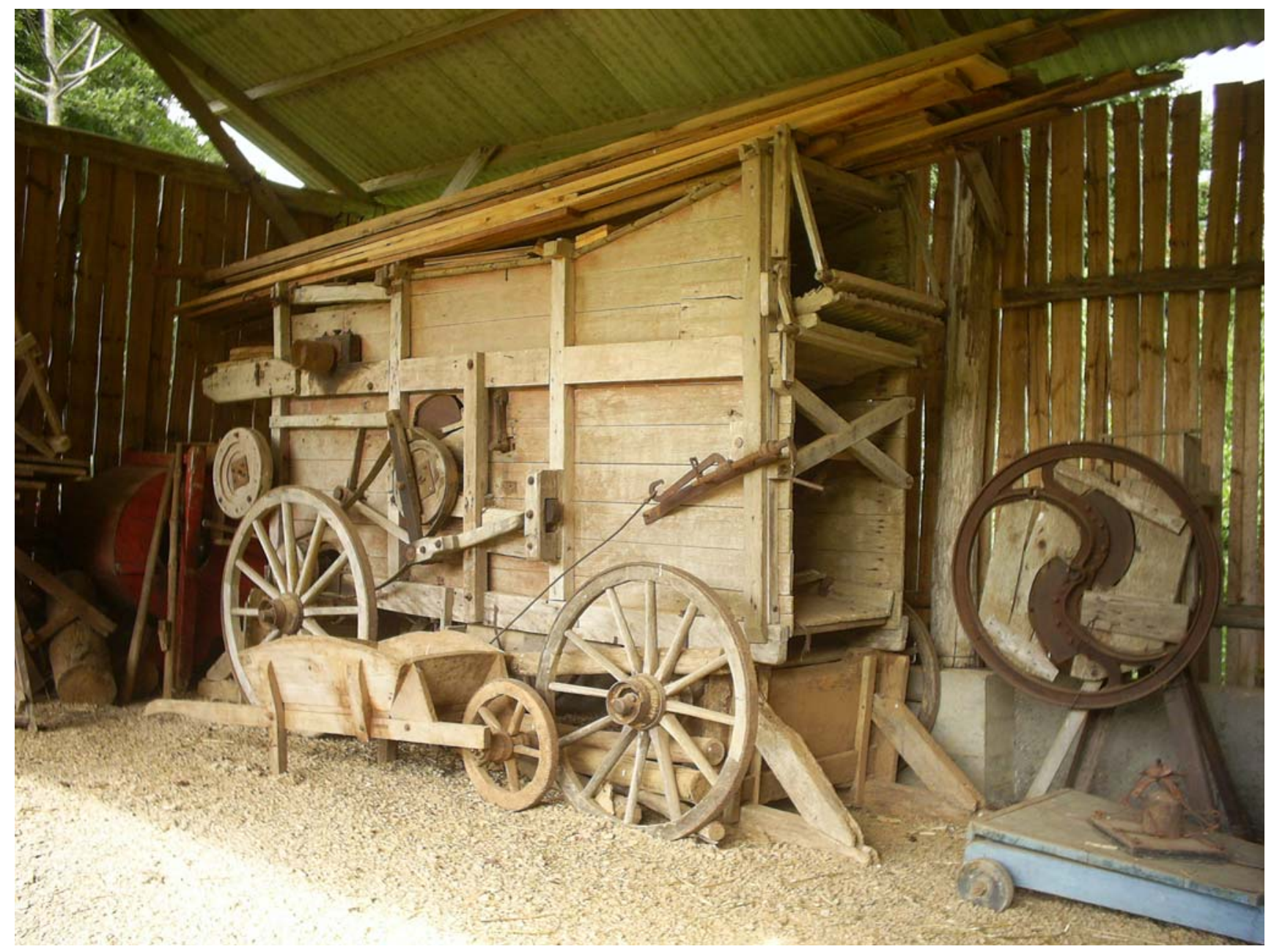

Máquina colheitadeira desenvolvida pelo Sr Maus, na década de 1930 


\section{A contribuição polonesa}

Os poloneses, sendo uma das mais influentes correntes de imigração da história paranaense, também trouxeram a tradição do uso da madeira para suas construções. As casas de tronco falquejados com encaixes nos cantos foram amplamente utilizados na fundação de suas colônias em Curitiba, a partir dos anos 1870. Essa técnica construtiva evolui nos processos de ampliação das construções dos sítios rurais para as construções com tabuas e sarrafos, que resultam na elaboração de um padrão específico de construção, denominado regionalmente como "casa de polaco".
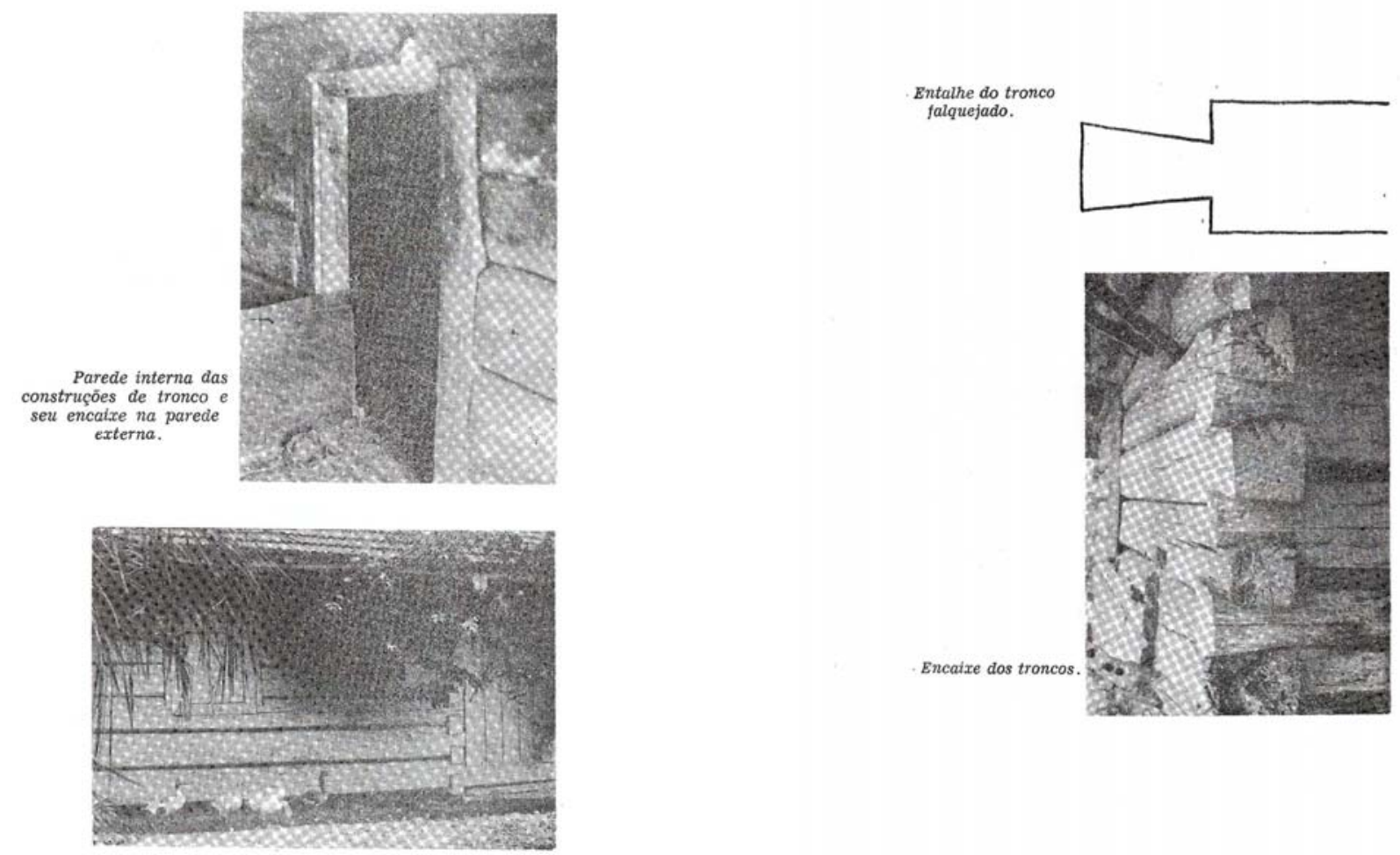

Detalhes de casa de tronco na colônia Tomás Coelho, Curitiba, final do séc. XIX Fotos do livro Arquitetura do Imigrante Polonês, de Jussara Valentini

Essa técnica construtiva evolui nos processos de ampliação das construções dos sítios rurais para as construções com tabuas e sarrafos, que resultam na elaboração de um padrão específico de construção, denominado regionalmente como "casa de polaco". 


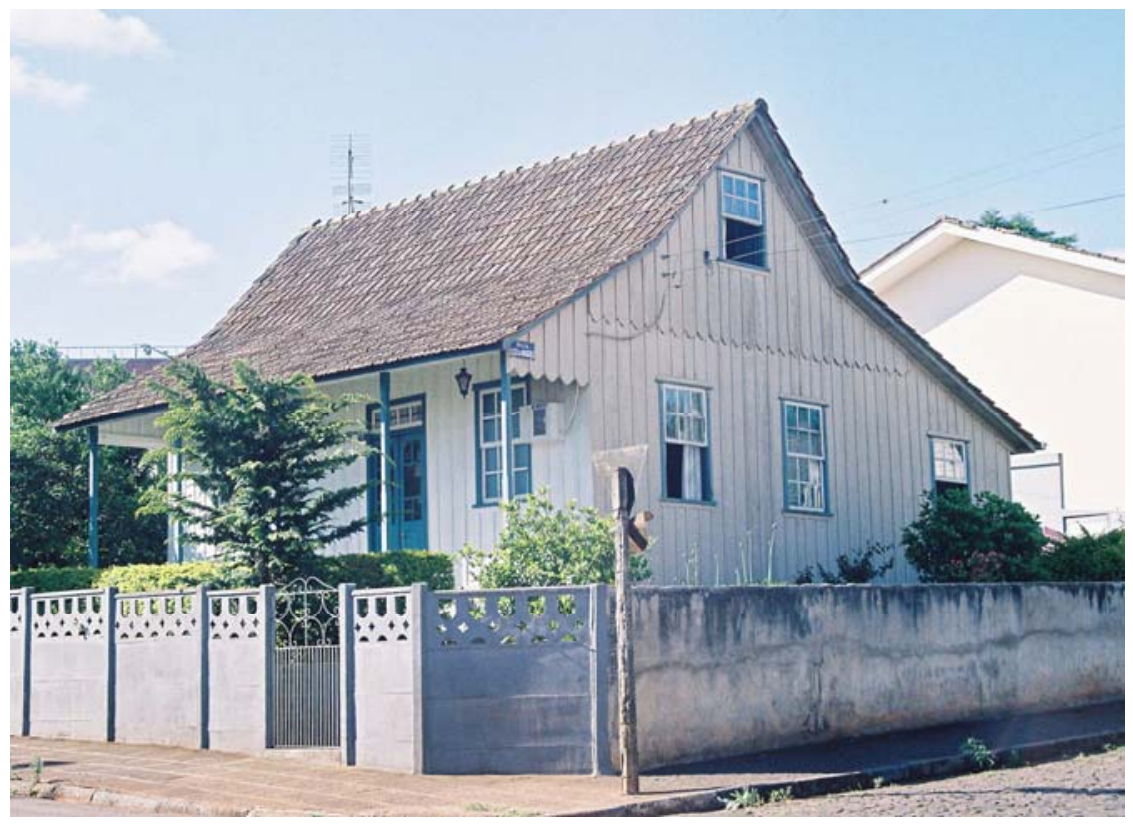

TÍPICA “CASA DE POLACO" - CONSTRUÍDA NA RUA LEOPLOLDO CUNHA EM 1920 FOTO AK - 2006

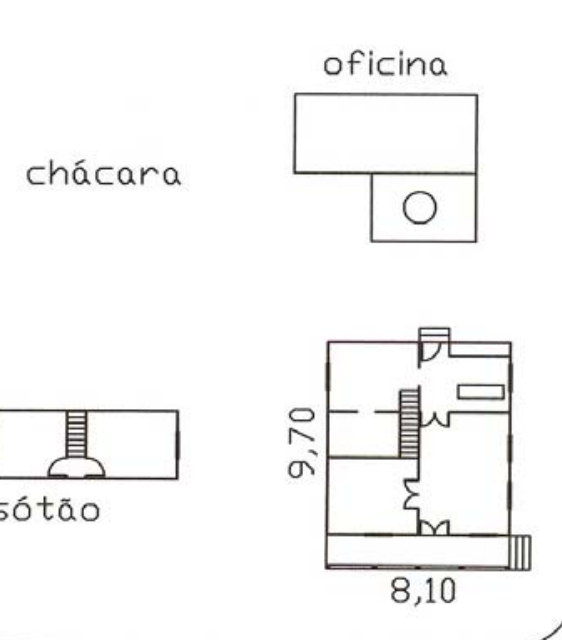

RUA LEOPOLDO CUNHA

VILA DFICINAS 


\section{A contribuição ucraniana}

Os ucranianos, com participação expressiva na colonização do sul do estado, mantenedores de ricas tradições folclóricas e religiosas, realizaram magníficas construções, verdadeiros marcos culturais em suas igrejas em madeira ou alvenaria, preservando a tradição cultural bizantina, de rico conteúdo nas áreas da arquitetura e pintura. A tradição cultural ucraniana no sul do Paraná é uma das mais expressivas no mundo além de suas fronteiras, e merece estudos acadêmicos mais profundos que certamente se constituirão em valiosa contribuição para o campo das artes plásticas.

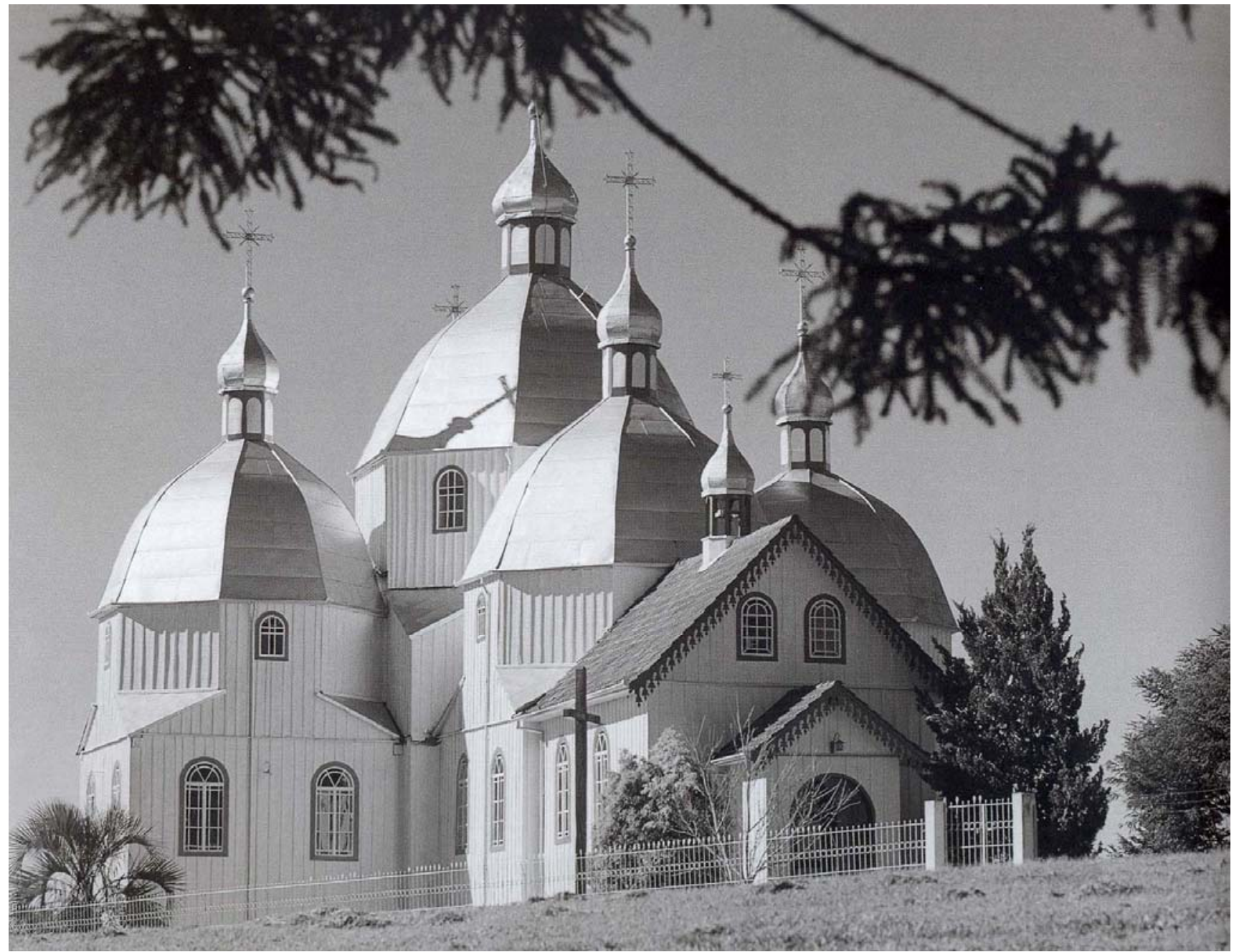

Igreja ucraniana de São João, município de Antonio Olinto

Foto do livro Igrejas de Madeira do Paraná, de Nego Miranda,2003 


\section{A contribuição italiana}

Os italianos realizam colonização no estado a partir de 1860 e na capital em 1878, com casas em madeira e alvenaria. (nota texto Casa Romário Martins) Sua contribuição está no uso da linguagem clássica na composição da arquitetura, conforme o texto do arquiteto Key Imaguire:

"Decorrência da planta é a volumetria sempre idêntica das edificações. As proporções do retângulo da planta repetem-se na elevação principal e na posterior, sendo as laterais com tendência ao quadrado. Esse paralelepípedo retângulo, quer nos casos de construção térrea ou assobradada, é coberto por um telhado de duas águas."

Também a composição das fachadas das casas italianas possui uma característica própria de simetria e proporção na disposição de colunas das varandas e distribuição das aberturas de portas e janelas, conforme demonstra a ilustração.

Casa Slompo, colônia Santa Felicidade, Curitiba, de fins do séc. XIX

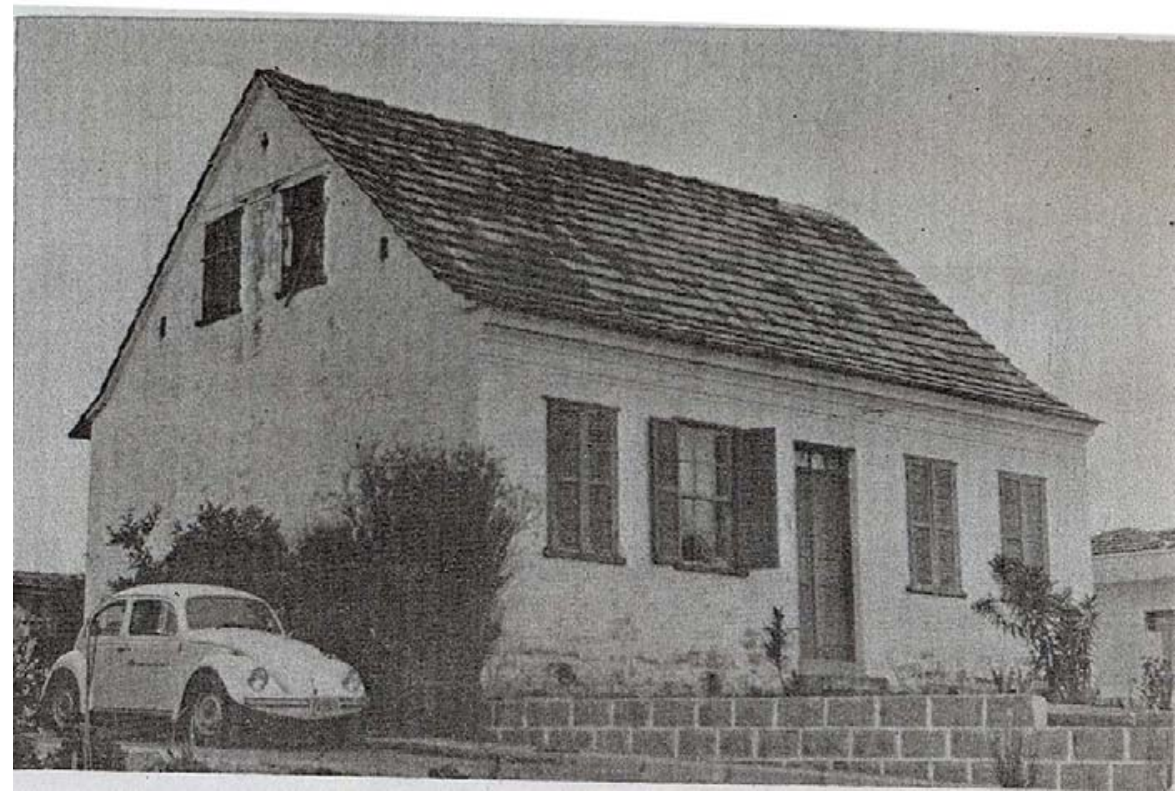

foto do Boletim 24 - Casa Romário Martins - pg. 47

Os japoneses também trouxeram uma arquitetura de madeira própria, que foge da abrangência desse estudo por se localizar nas regiões norte do estado.

Os ingleses tiveram um papel empresarial na colonização do estado, com a implantação da rede ferroviária e a fundação de cidades através de companhias colonizadoras. Sua participação se relaciona com a difusão das novas tecnologias industriais relacionadas ao novo transporte e aos fatores culturais correlatos, tais como as idéias românticas do ecletismo em arquitetura. 
Capítulo 4

\section{AS CASAS DE CHÁCARA}

Na seqüência dos estudos das determinantes que influenciam a formação da arquitetura de madeira em Ponta Grossa, cabe anotar a questão da implantação no lote. As colônias da região foram instaladas distantes de 6 a $30 \mathrm{~km}$. do núcleo urbano. As mais distantes foram desativadas, enquanto as mais próximas foram incorporadas, tornando-se atualmente bairros da cidade: colônia Rio Verde, colônia dona Luiza, colônia Nova Rússia. No final do século XIX a periferia do centro da cidade era formado por chácaras, onde havia a produção de hortifrutigranjeiros. Essas chácaras foram sendo subdivididas até a configuração de lotes urbanos convencionais com dimensão em torno de 14X30m. Apresentavam um modo de vida peculiar, com características simultaneamente urbanas, devido a sua proximidade do centro e rurais, pela produção de hortas, pomares de variadas espécies inclusive vinhedos e a criação de gado, suínos e aves. É um período significativo para o modo de vida das populações dos bairros e toda a cidade, gerando uma estrutura habitacional própria, ainda existente no ano de 2007.

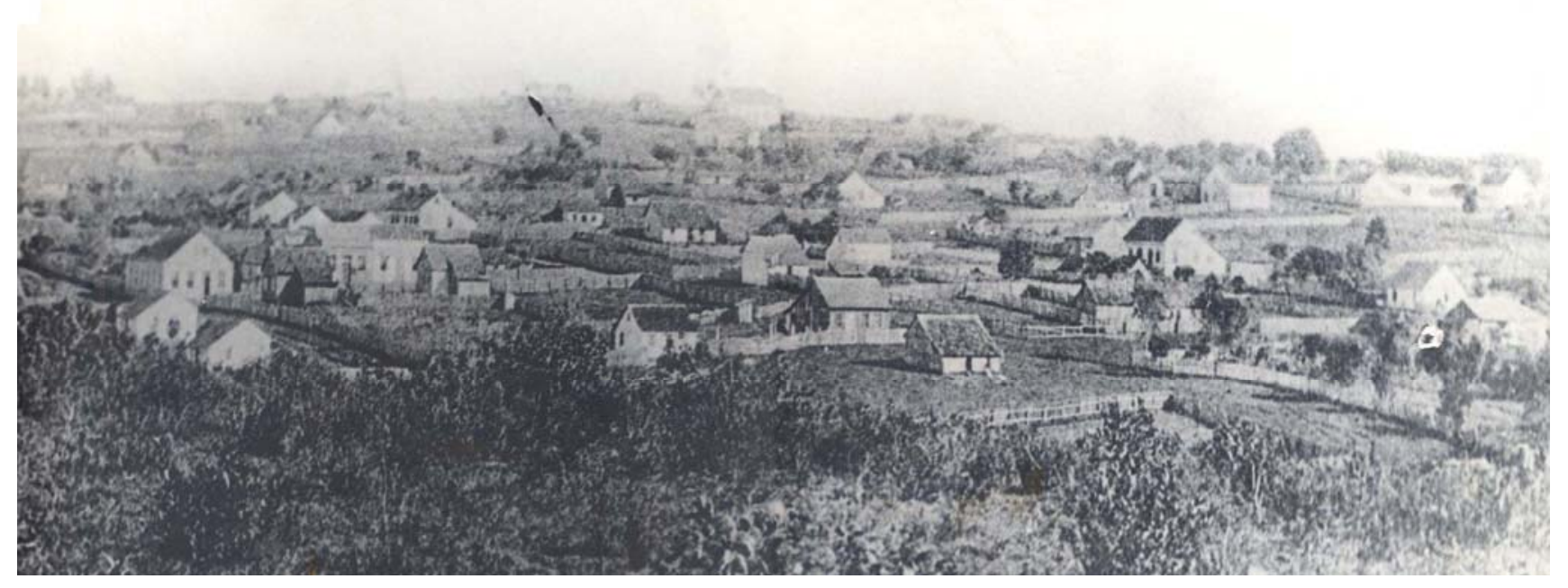

Vista da cidade, no alto da rua Balduino Taques, em 1892 - observa-se as chácaras e casas típicas

Foto acervo Casa da memória 
É característica da arquitetura dos bairros da cidade, inclusive com exemplares próximo do centro, a arquitetura de casas de chácara de madeira, destacada no terreno, com ajardinamento, e lambrequins, sótão. As varandas faziam a transição entre o espaço externo relacionado ao trabalho na terra com o interior da habitação. Integra esse conjunto a "casa do poço", um anexo em "meia-água" (cobertura de um só plano de inclinação), nos fundos, paralelo à cozinha, fechado por três lados e que se abria para o lado da casa, onde se localizavam o poço e os serviços de lavagem de roupa.

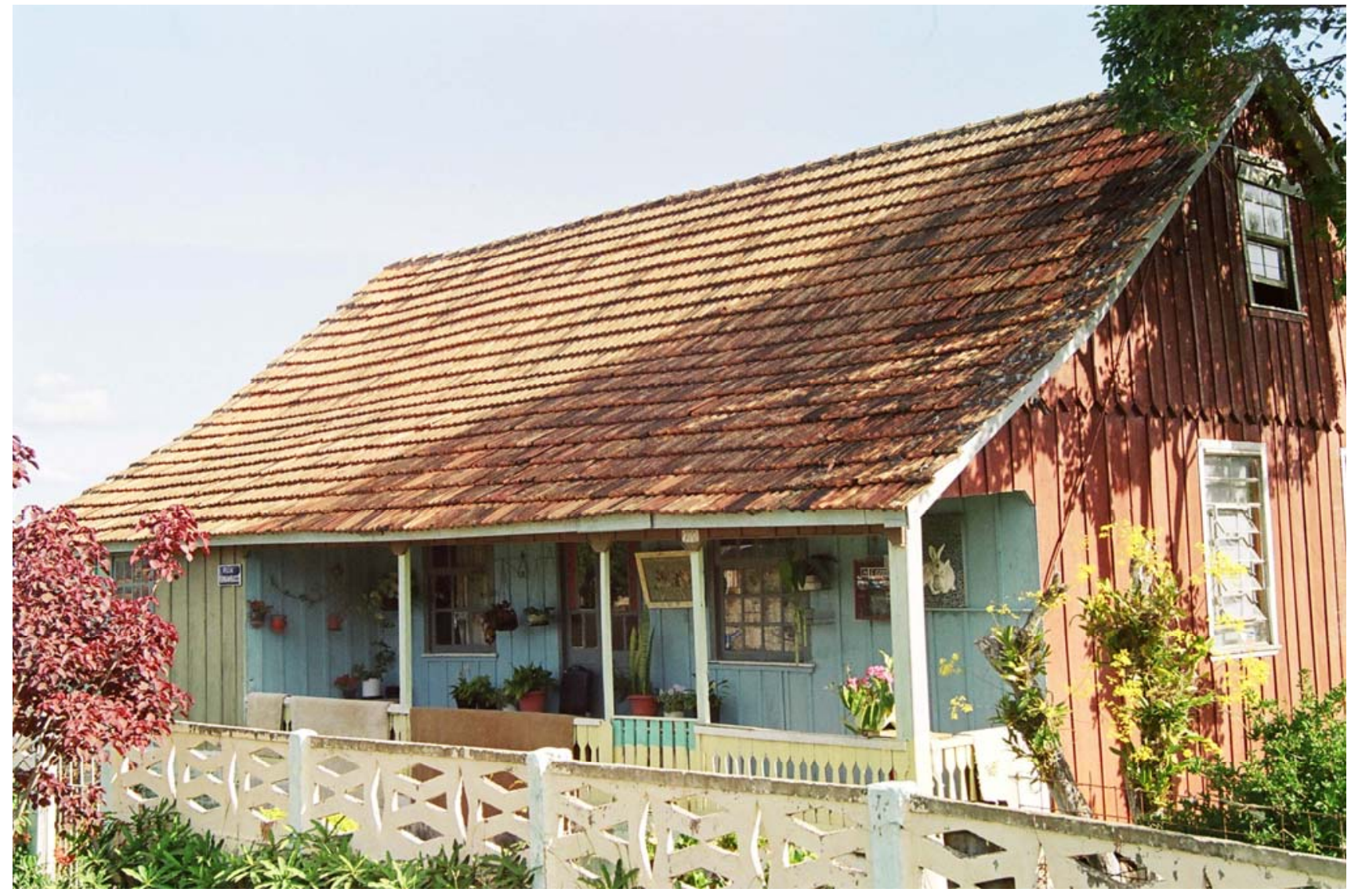

Casa de chácara do bairro de Olarias Foto AK, 2006 
Na mesma construção ficava a despensa para as ferramentas de lida na terra. Junto ficava o forno de pão, em arco de tijolos e a caixa d'água, com estrutura de madeira e abastecimento através de bomba manual ou elétrica. Nas chácaras maiores existiam os paióis, barracões de madeira com cobertura em duas águas para o abrigo da carroça ou automóvel, e oficinas de carpintaria e utensílios de horticultura. Anexos também ficavam o galinheiro, em alguns casos com patos e perus, em outros um pequeno estábulo e pocilga de porcos. O sanitário em fossa negra, denominada "casinha".

\section{A CASA DO IMIGRANTE URBANO}

Existem dois tipos básicos na história da casa de madeira na região de Ponta Grossa.

O primeiro conhecido como "casa de polaco", possui implantação transversal em relação ao terreno ou acesso principal, com varanda e a entrada principal no centro desta. Complementam esta tipologia o telhado de inclinação alta que abriga o sótão e um prolongamento da cobertura, onde se localiza a cozinha, que gera uma quebra típica na sua linha de caimento. O volume é simples, de caracterização imediata. Esta tipologia é a mais antiga, derivada da tradição colonial portuguesa de casas em fita, que vai se modificando com o processo de miscigenação da colonização.

O segundo tipo básico está relacionado com o lote urbano de aproximadamente $14 \times 30$ metros. A implantação é longitudinal, integrada com as laterais do terreno, com a possibilidade de melhores aberturas de janelas para a higienização, valorizada na época. A varanda e a porta principal passam a ser laterais, em alguns casos também na frente, ou mesmo nos três lados.

Daí surgiu a tipologia básica das plantas das casas de madeira do século XX de Ponta Grossa: a planta bicameral. Na maioria das casas a planta divide-se longitudinalmente em duas alas. De um lado a área coletiva, normalmente a partir da varanda externa, e do outro a ala dos dormitórios, que formam o volume de oitão da fachada. 


\section{OS LAMBREQUINS}

São ornamentos de madeira ou zinco,de aproximadamente 40 a $60 \mathrm{~cm}$, com desenhos estilizados colocados nos beirais das casas, caracterizando um acabamento de efeito poético, próprio da arquitetura do imigrante.

Pode-se fazer uma classificação dos lambrequins a partir de seus desenhos. Os mais simples e quadrados são de origem polonesa. Os mais arredondados são de origem germânica, e os mais detalhados tipicamente italianos. (citar gazeta)

Existem outros acabamentos que complementam a casa de madeira t[ipica do imigrante europeu: os rendilhados dos frontões e empenas e as molduras das varandas, que podiam também ocorrer no interior das casas e mesmo dos móveis. $\mathrm{O}$ arquiteto Antonio Carlos Zani, em tese de doutorado na FAU/USP, sobre a arquitetura de madeira norteparanaense, cita uma verdadeira competição entre os carpinteiros da região, nas décadas de 1940 e 1950, pois eram qualificados segundo o grau de elaboração desses ornamentos. Em Ponta Grossa identificamos construções de madeira de alto grau de acabamento que merecem estudos específicos.

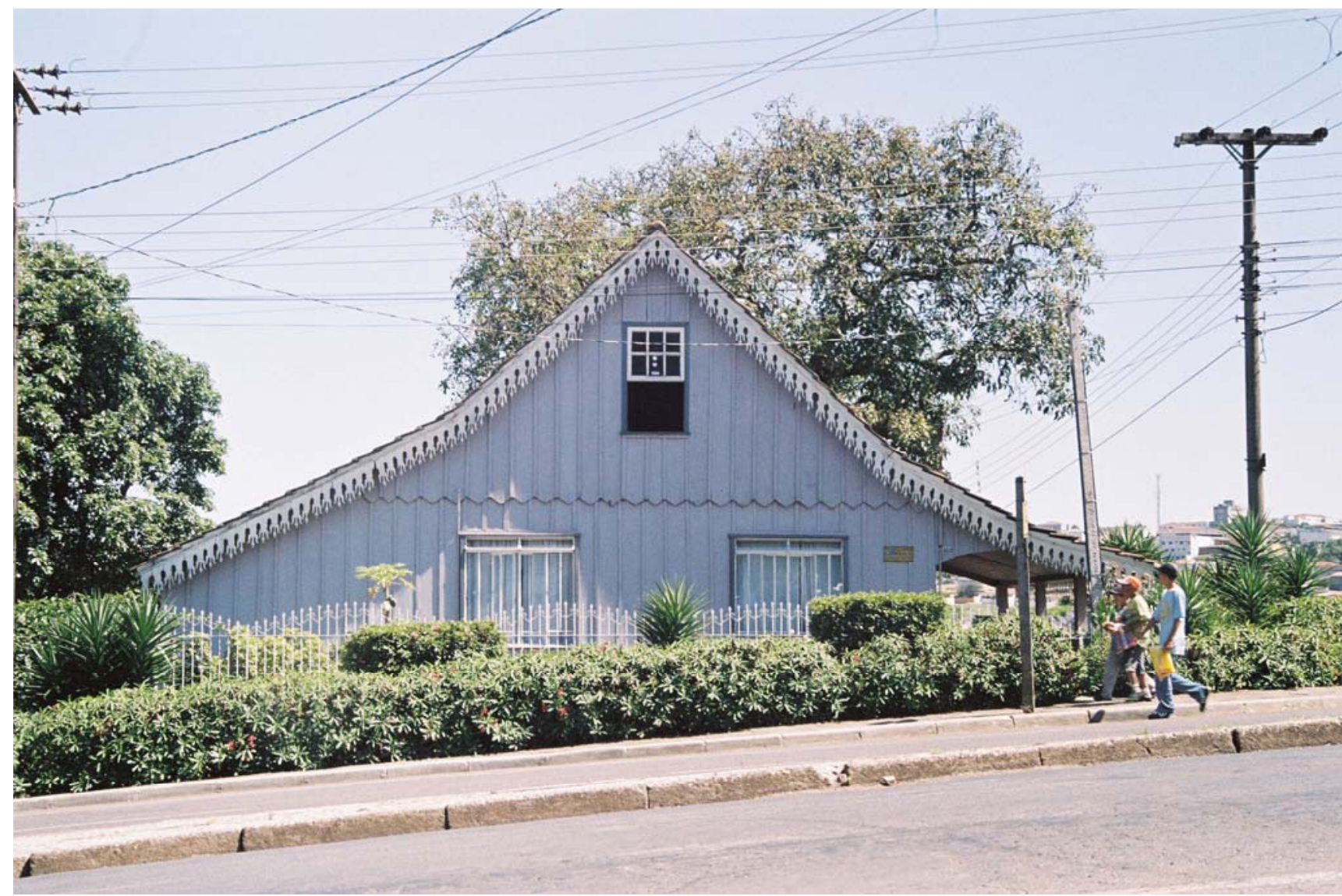

Casa da imigração na rua Ayrton Playsant, bairro da Ronda Foto AK, 2006 


\section{O CHALÉ E O BANGALÔ}

A virada do século traz para Ponta Grossa a república, a implantação da prefeitura, a estrada de ferro, com o desenvolvimento de um próspero comércio regional, além da indústria ervateira e da madeira. Junto com o progresso, nome do primeiro jornal da cidade, vem o ecletismo europeu que expressava as profundas modificações culturais que ocorriam no mundo através da revolução industrial. O ecletismo era um sinal de modernização para os cidadãos da época.

Inspirado nos ideais do romantismo surge no desenvolvimento urbano das cidades européias o "chalé", que consistia em uma pequena propriedade, com arquitetura típica construída numa chácara, nas proximidades do centro urbano, e se caracterizava pelo contato com a natureza. Esse padrão arquitetônico é bastante difundido nas cidades brasileiras, influencia a caracterização das casas de madeira de Ponta Grossa, conforme observamos no capítulo referente aos projetos aprovados na prefeitura local.

O romantismo trouxe também uma das mais expressivas contribuições para a arquitetura das casas de madeira de Ponta Grossa - o bangalô. O termo surgiu da colonização inglesa na Î́ndia, derivado de Bãnglã, da língua Bengali, caracterizando a tipologia própria de uma casa baixa com varandas em todo o perímetro. O governo inglês construía abrigos a cada 12 a $15 \mathrm{~km}$. nas principais estradas da Índia para a estadia de seus funcionários viajantes. Essas construções assimilaram os padrões formais da arquitetura banglã local, sendo trazidas ao Brasil junto com a construção das ferrovias e de suas casas. 


\section{O SISTEMA DE PRODUÇÃO DA MADEIRA}

A industrialização criou um padrão de beneficiamento da madeira em peças relativamente padronizadas que se adaptavam ao processo construtivo das pequenas casas. Esse sistema empírico era amplamente utilizado pela população e seus construtores, constituindo um saber popular que permitia a utilização do material sem a necessidade de cálculos especializados, embora também limitasse a variedade de soluções plásticas e formais das construções.

Uma característica interessante do sistema de padronização da madeira, também chamadas "bitolas", é que sua unidade de medida é ainda hoje popularmente referida no sistema inglês de polegadas, devido à influência no período de implantação da ferrovia e da indústria de beneficiamento.

\section{A TÉCNICA CONSTRUTIVA}

Fazer a casa de madeira era um conhecimento empírico difundido entre os construtores e carpinteiros da região. Seus fundamentos originam na tradição de corporações seculares e podiam ser visitados pela simples observação dos modelos existentes, permitindo alguma variação com a troca de experiências e informações pela prática cotidiana, amadurecida por vários anos.

A casa de madeira era sempre construída elevada do solo, no mínimo em meio metro, para permitir que a ventilção mantivesse seca sua estrutura. $O$ apodrecimento da madeira é um fenômeno biológico de ação de fungos que se desenvolvem na umidade. As estruturas de madeira secas e protegidas de cupins, tem demonstrado durabilidade de séculos.

A base da casa é uma grelha de vigas de $10 \times 5 \mathrm{~cm}(4 \times 2$ ") que se apóia em pilaretes de tijolos, pedra, ou mesmo madeira de lei.

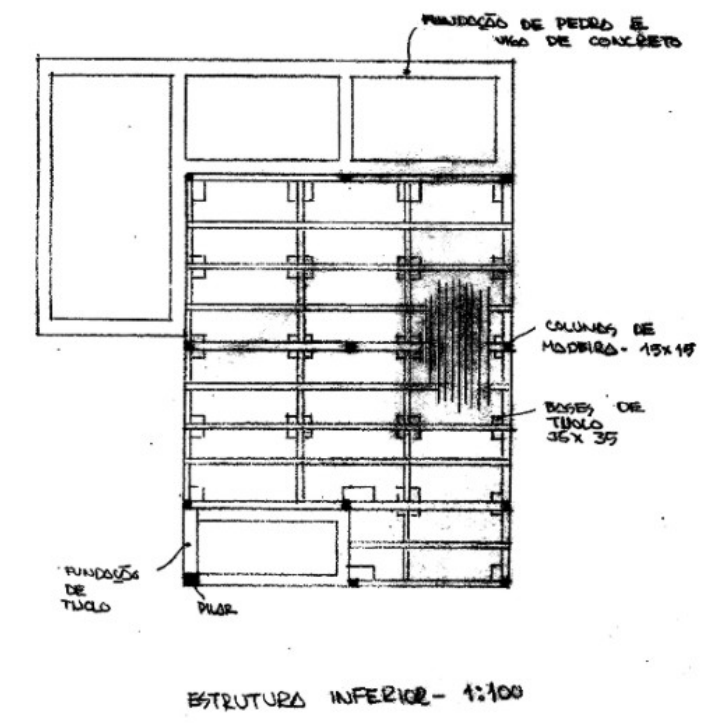

Estrutura do assoalho de casa de madeira - desenho AK - 1982 
Construía-se o assoalho das casas antigas com tabuas largas e sem encaixes, que causava um frio intenso no inverno do sul. Por isso era usado sarrafear a parte inferior dos asoalhos. Depois passaram a serem usadas tábuas com encaixe macho e fêmea.

Sobre o asssoalho era levantada a estrutura de pórticos em coluna e vigas, de dimensões aproximadas de 15×15 cm ( $6 \times 6$ "). O espaçamento das colunas destas estruturas, aproximadamente 3,00 metros, correspondia à dimensão dos cômodos da casa, embora pudesse ser modificado para outras soluções.

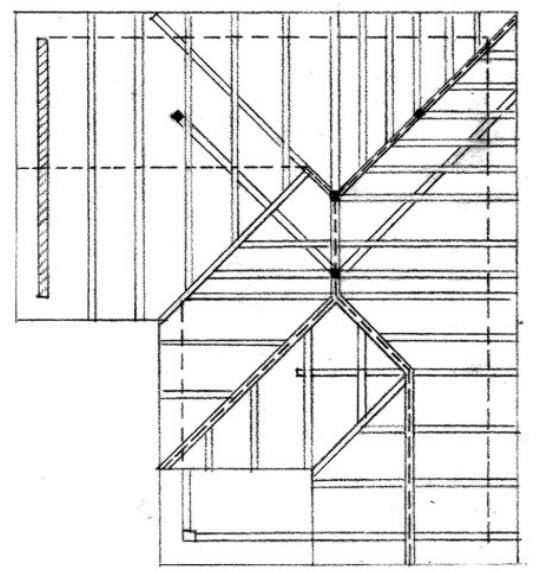

ESTRUTORA DO COBERTURA - 1:100

O forro, inicialmente de taboas largas, com sobreposição alternada em duas camadas, passou a ser do tipo "forro paulista", de taboas estreitas e mais leves, com encaixe macho e fêmea, de dimensões 10 X1,2 cm.

As janelas de madeira ou ferro eram fixadas diretamente no plano formado pelas tábuas de vedação, sem necessidade de reforços mesmo nas portas. As janelas de madeira eram normalmente no sistema de guilhotina vertical, com venezianas que podiam ser externas ou internas, daí ocasionando que os vidros ficavam expostos no lado de fora da casa.

Várias casas apresentavam um sistema misto de construção em madeira e alvenaria. As mais antigas usavam fazer a fachada em alvenaria, com a platibanda e ornamentos característicos do ecletismo, buscando melhorar a apresentação da construção. Também eram usuais as ampliações de cozinha e banheiro nessa técnica. 


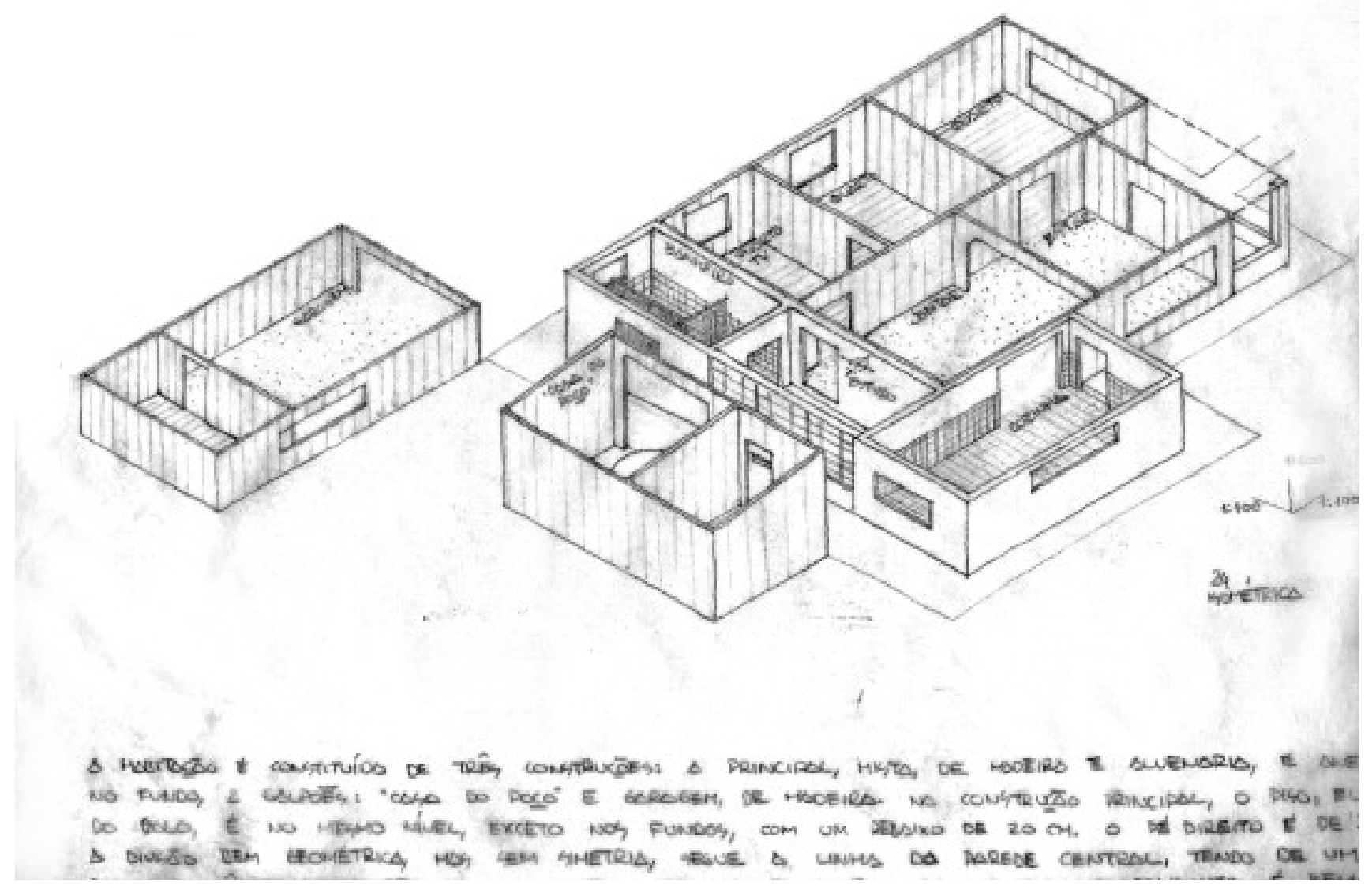

Isometria da casa do autor: madeira, anexos e ampliação da cozinha em alvenaria - AK 82

Existe na região o costume de revestir a construção de madeira com paredes de alvenaria, gerando um novo padrão de arquitetura pelo aproveitamento da estrutura interna, normalmente bem conservada. 
Capítulo 5

\section{CATALOGAÇÃO DE PROJETOS DE CASAS DE MADEIRA OU MISTAS DAS DÉCADAS DE 1920 A 1950 DA PREFEITURA DE PONTA GROSSA}

Fazendo uma observação geral das centenas de imagens, desenhos, plantas, fragmentos, detalhes, fotos, anotações e memórias que buscam aprofundar o conhecimento do processo histórico da formação da cidade, pudemos perceber um acompanhamento paralelo, como que o surgimento de uma segunda história, mediatizada pelos vários recursos, pelos processos de reflexão.

Mas a questão é justamente a riqueza de sugestões e as oportunidades que o desenvolver dessa reflexão proporcionam ao arquiteto de hoje. Descobrir como se forma a cidade, sua gênese, seus processos, ciclos, princípios, impulsos, barreiras, determinantes e limitações. Os pensamentos das épocas, as interações das classes, tudo contribui para a construção da cidade. A cidade é a interação e a espacialização da sociedade, e essa visão em conjunto deve ser mantida.

Assim, sobrevoando essa colcha de retalhos que são os indícios da memória da história da cidade, vemos a época dos desenhos eufóricos do ecletismo, que transmitia a mesma vitalidade do "novo século" para as construções dos chalés e das casas de madeira dos imigrantes, mantendo a velha implantação transversal e o telhado empinado, quebrado nos fundos. A casa no alinhamento constrói a calçada e a rua, ou se afasta para gerar um pequeno jardim. Nesse tempo as fachadas eram em alvenaria, enobrecendo com platibandas e cimalhas a intersecção entre o público e o privado e a apresentação social dos moradores.

Notamos os afastamentos laterais das casas dos imigrantes e das casas ecléticas, algumas com graciosas varandas ou até pórticos laterais, cercadas de jardins.

A transição entre o público e o privado é sempre elaborada no interior das casas, surgindo soluções com salas comerciais de uma ou mais portas e altas janelas abrindo para a rua, em cantos marcantes de esquinas. Soluções pitorescas que constroem a cidade, o espaço, o ambiente. Cabe aqui lembrar a maestria estética dos edifícios que formavam a esquina da rua XV com a rua Sant'Ana nos anos 1940.

É poética a simplicidade das casinhas de madeira resistindo bravamente ao crescimento da cidade, guardando os segredos de uma estética tão elaborada que o único elemento além de uma essência minimalista seria a delicadeza sinuosa de uma linha de lambrequins, que só poderia estar ali, no equilíbrio perfeito da proporção das paredes com o telhado com sua textura e cores variantes com o caminho do sol. Delicadeza da linha quase imoerceptível da moldura de tábuas de um oitão. 
Interessante observar os fragmentos da arquitetura. Platibandas, cimalhas, janelas com linhas sinuosas, molduras, frisos, cunhais, peitoris, lambrequins, portões, gradis e gateiras em ferro trabalhado, formando um rico jogo de imagens e sugestões. De que tempo, espírito e arte falam essas coisas? Que sugestões evocam para a nossa arquitetura?

Observamos em algumas casas da década de 1920 uma integração ente os cômodos sem o uso do corredor de circulação. A existência dos sótãos, lugares mágicos, com telhados empinados com a janelinha no alto. Alguma coisa aconteceria ali. As escadas íngremes, rangentes. Espaços íntimos, acolhedores, aconchegantes, reservados ao repouso e ao isolamento, enquanto o convívio acontecia no térreo.

Observamos a beleza imponente, até majestosa de algumas fachadas ecléticas. Ornamentos que criam entes virtuais que participam da vida das pessoas, quase como as gárgulas e carrancas dos tempos antigos.

Percebemos que o desenho da planta da casa de esquina já indica a composição dos elementos da fachada, de seu chanfro e das várias aberturas. Pensar essa articulação dos espaços e da construção é criar uma nova arquitetura.

Observamos a multiplicidade de tendências vindas dos repertórios acadêmicos da história da arquitetura interagindo com os repertórios das várias etnias num momento de profundas transformações da noção de espaço urbano. Tentamos captar a seqüência da formação da cidade, inicialmente com seus casarios centrais justapostos no alinhamento das ruas, como ainda existe na rua Sant'Ana, e das casas de madeira dos colonos em suas chácaras na periferia. Observar a articulação das soluções espaciais, construtivas e estéticas do ecletismo, e os processos de geometrização e racionalidade característicos dos períodos decô e moderno, Processo histórico rico de conhecimento e soluções promissoras para aqueles que se dispuserem a conhecer e aprofundar os recursos de construção da cidade. 
LEVANTAMENTO DE PROJETOS DE CASAS DE MADEIRA APROVADOS NA PREFEITURA DE PONTA GROSSA NA DÉCADA DE 1920 

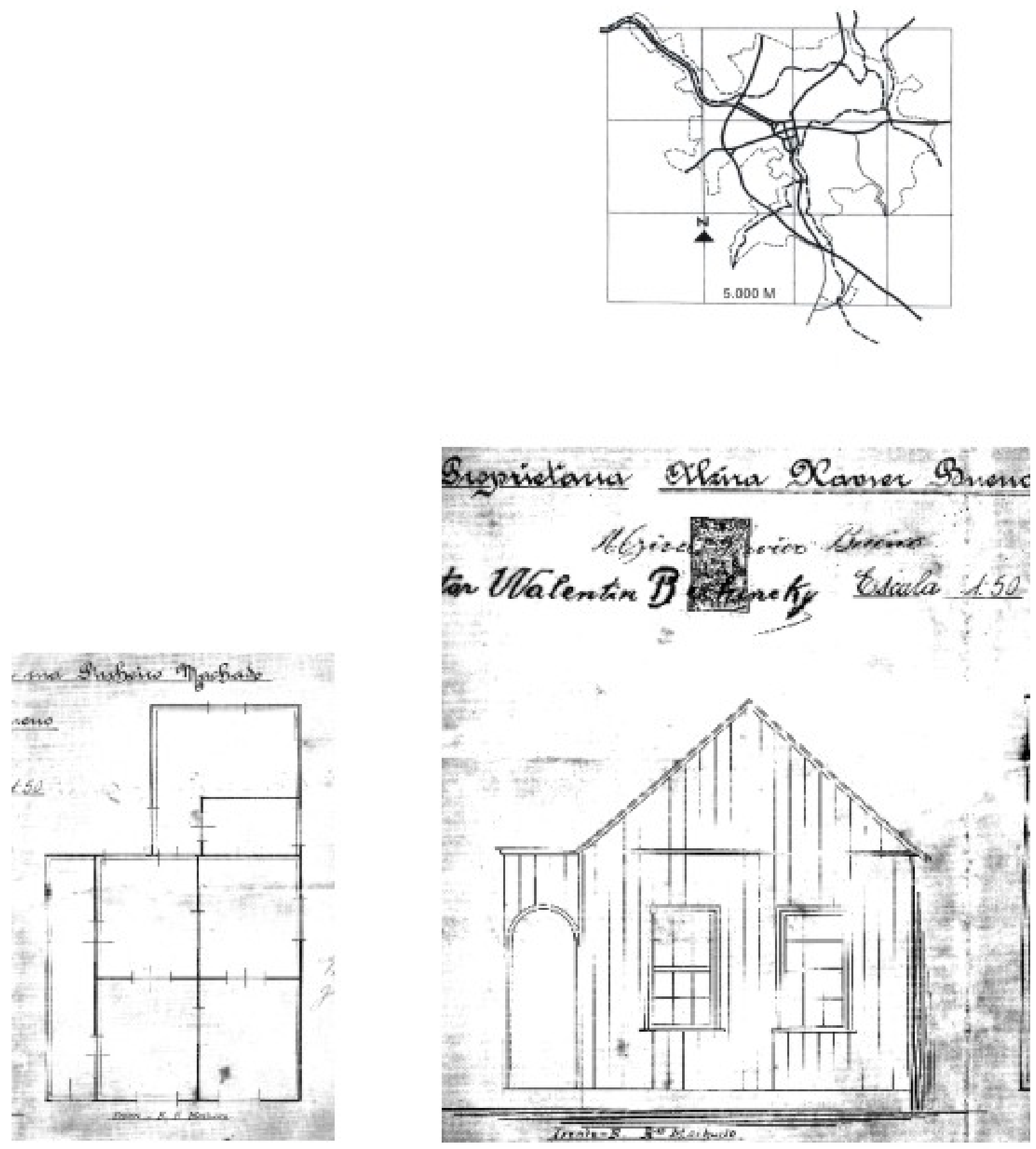

F001/21

Casa de madeira

Ano de construção - 1921

Prop. - Alzira Bueno

Uso residencial

Fonte: prefeitura/2006 

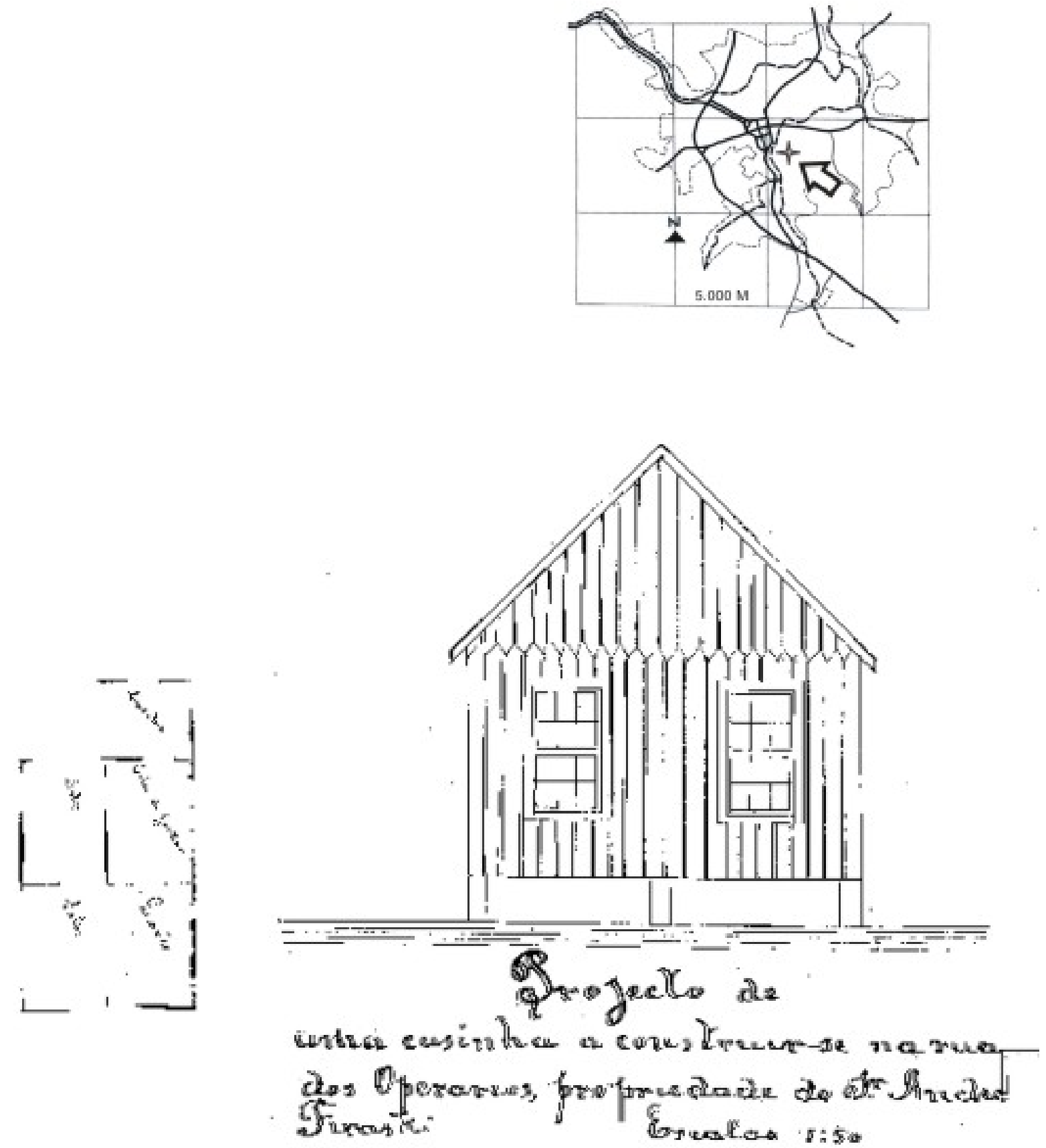

Ficha

Casa de madeira

Ano de construçăo - 1922

Proprietário - André Firaski

Uso residencial

Fonte: prefeitura/2006

Obs. Sem implantação 

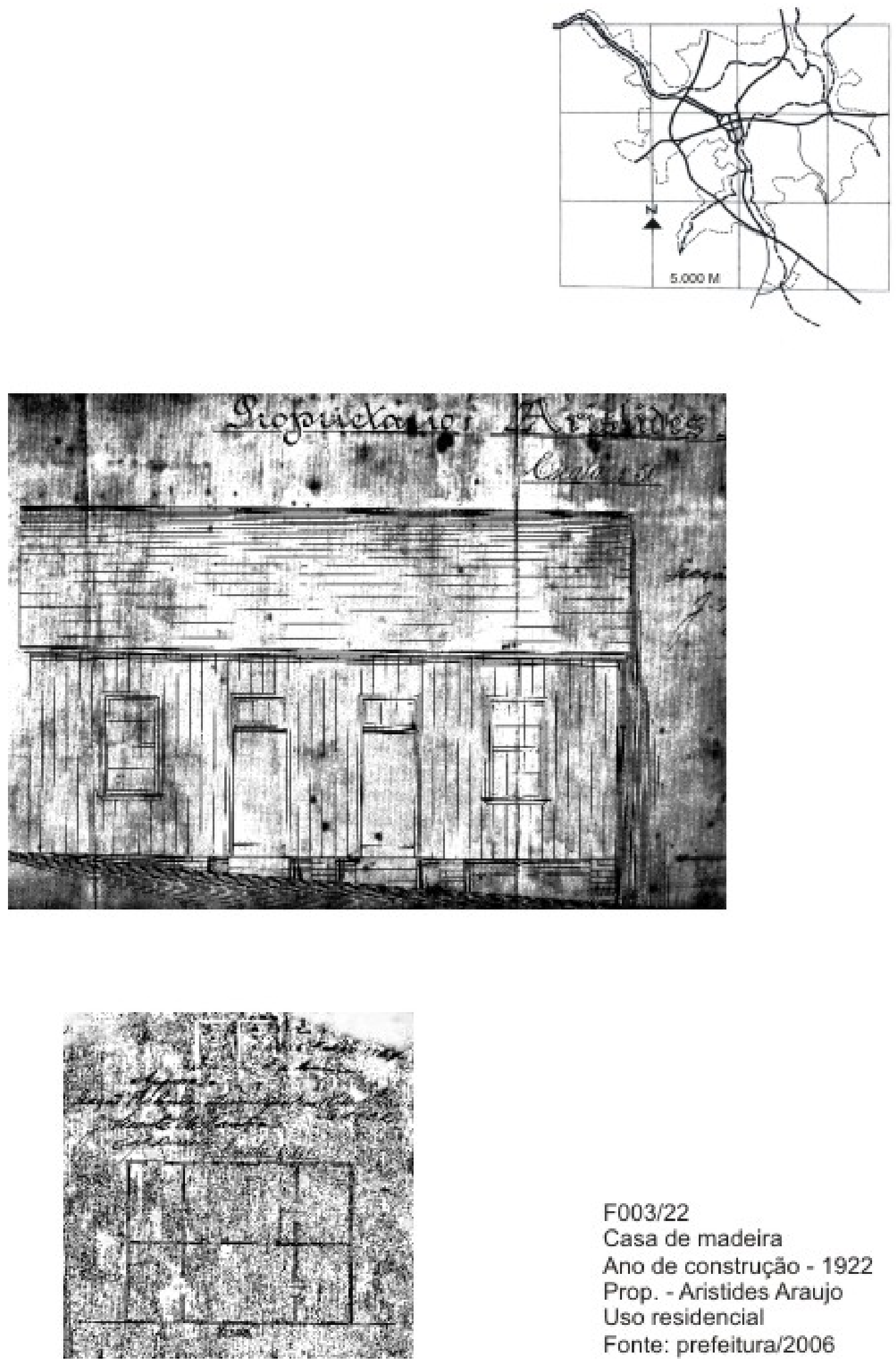

$\mathrm{F} 003 / 22$

Casa de madeira

Ano de construçäo - 1922

Prop. - Aristides Araujo

Uso residencial

Fonte: prefeitura/2006 

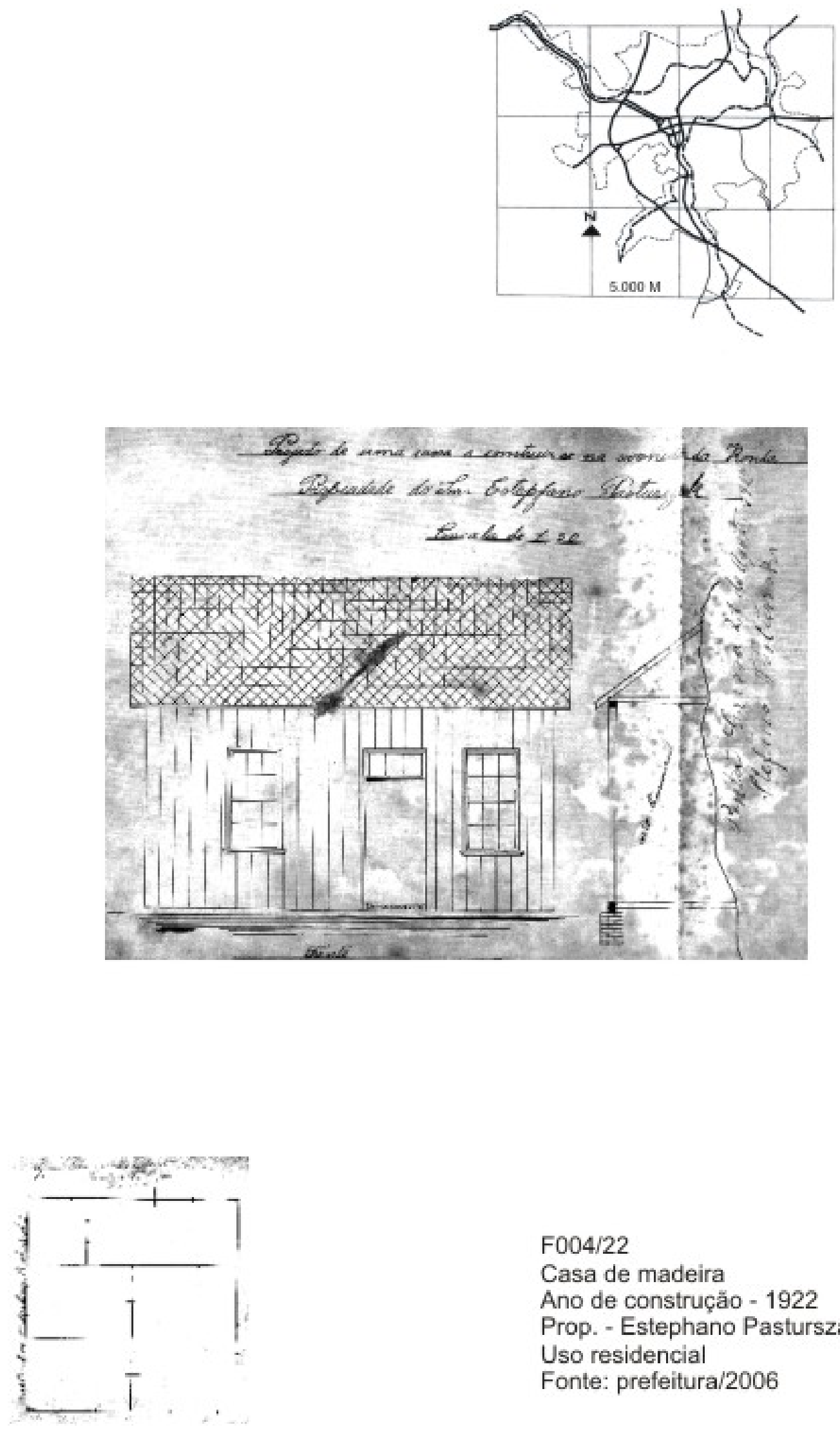

$\mathrm{F} 004 / 22$

Casa de madeira

Ano de construção - 1922

Prop. - Estephano Pasturszak Uso residencial

Fonte: prefeitura/2006 

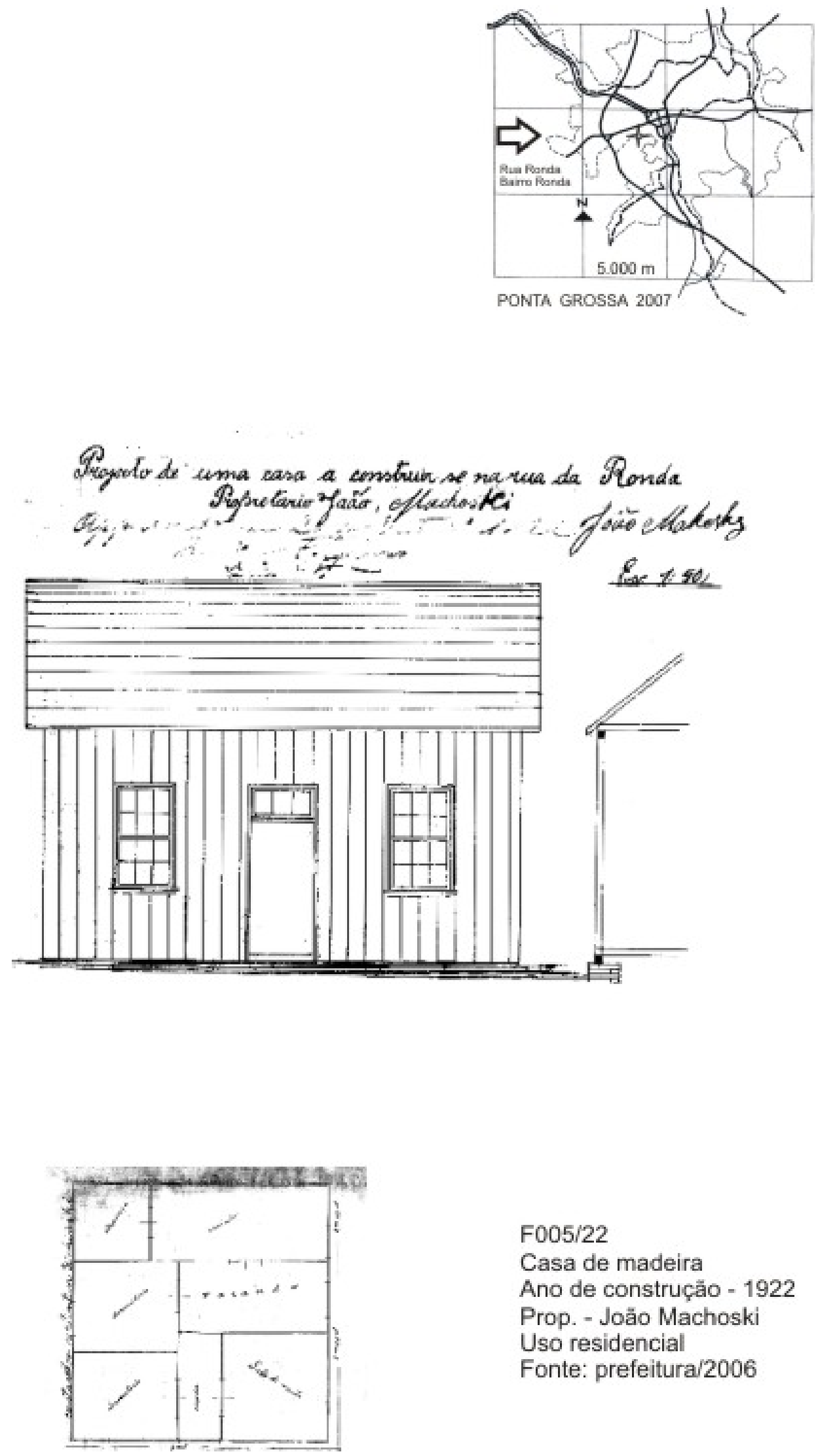

F005/22

Casa de madeira

Ano de construção - 1922

Prop. - João Machoski Uso residencial

Fonte: prefeitura/2006 

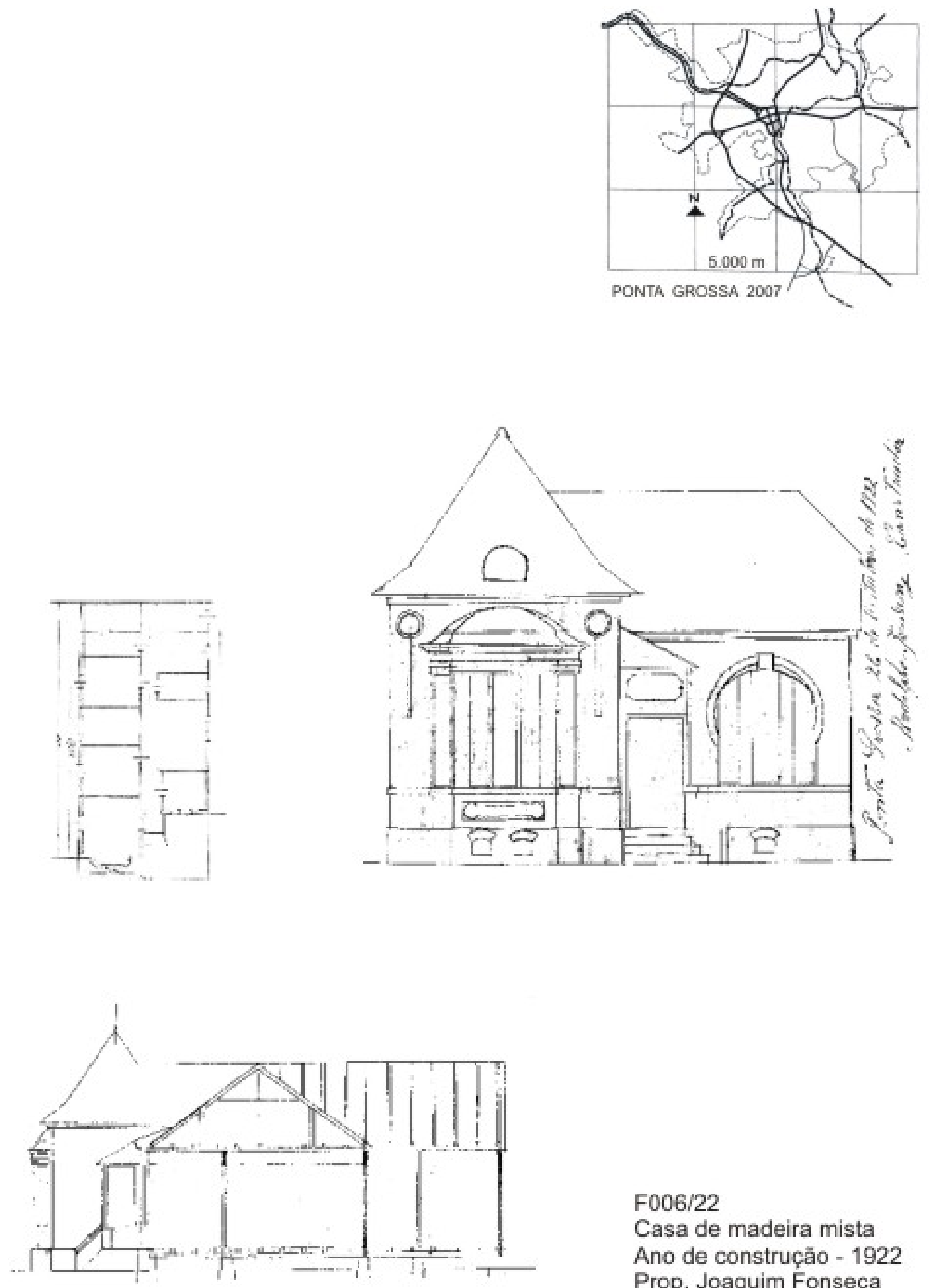

F006/22

Casa de madeira mista

Ano de construção - 1922

Prop. Joaquim Fonseca Uso residencial

Fonte: prefeitura/2006

Obs. - arquitetura eclética com interior em madeira 

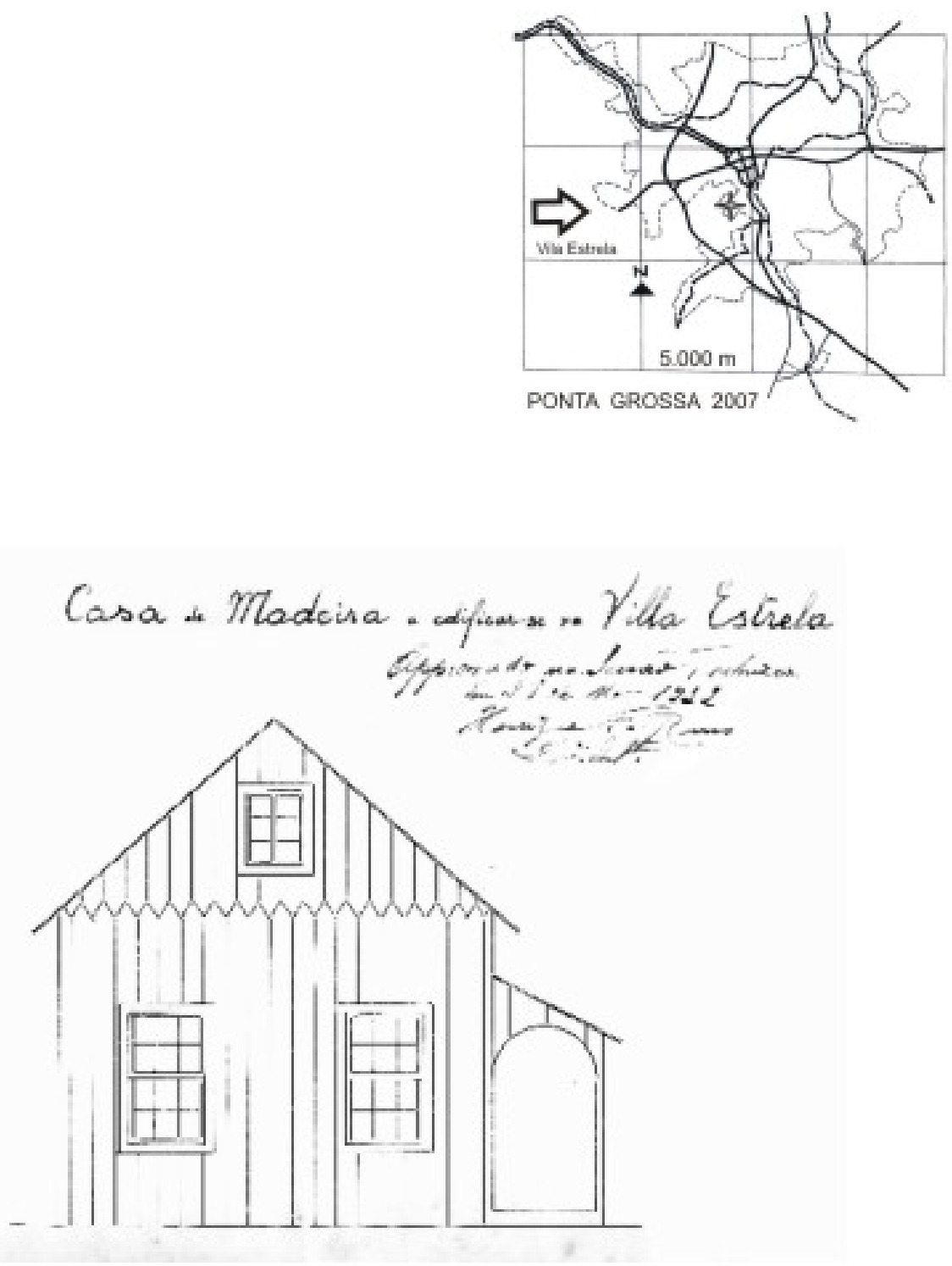

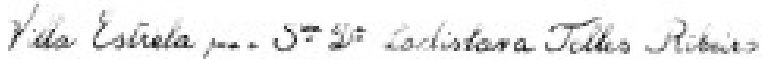

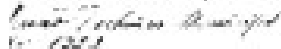

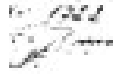

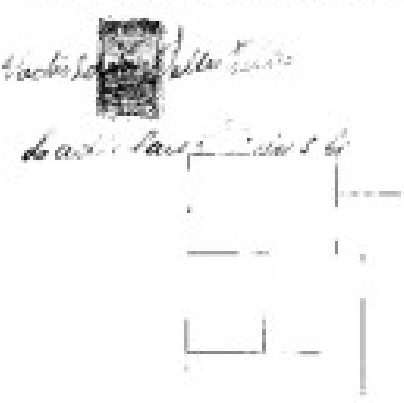

F007/22

Casa de madeira

Ano de construçäo - 1922

Prop. - Ladislava Ribeiro Uso residencial

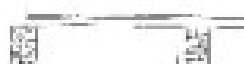

Fonte: prefeitura/2006 

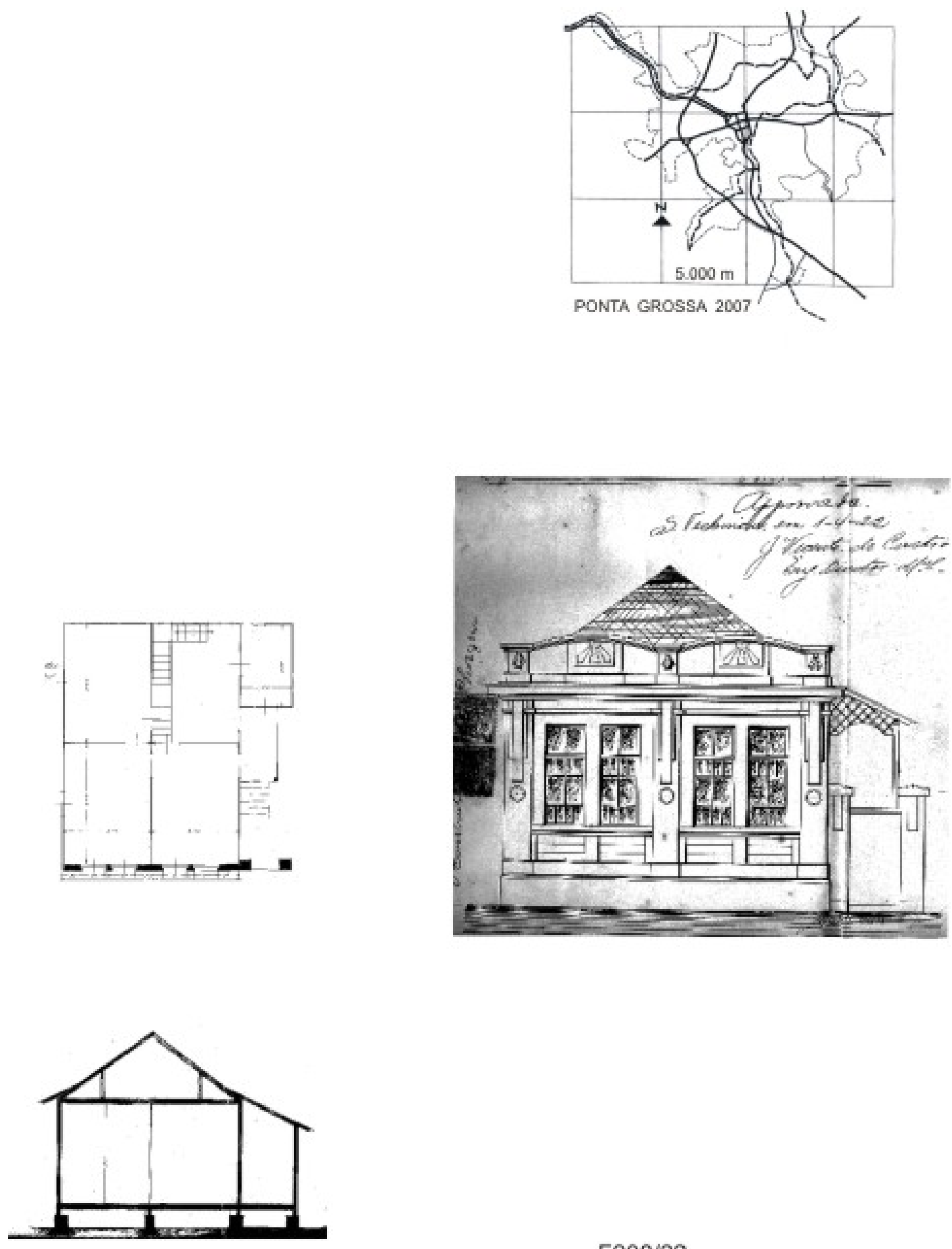

F008/22

Casa de madeira mista

Ano de construçäo - 1922

Prop. - Paulo Canto

Uso residencial

Fonte: prefeitura/2006

Obs. Fachada e implantaçäo tipicamente eclética 

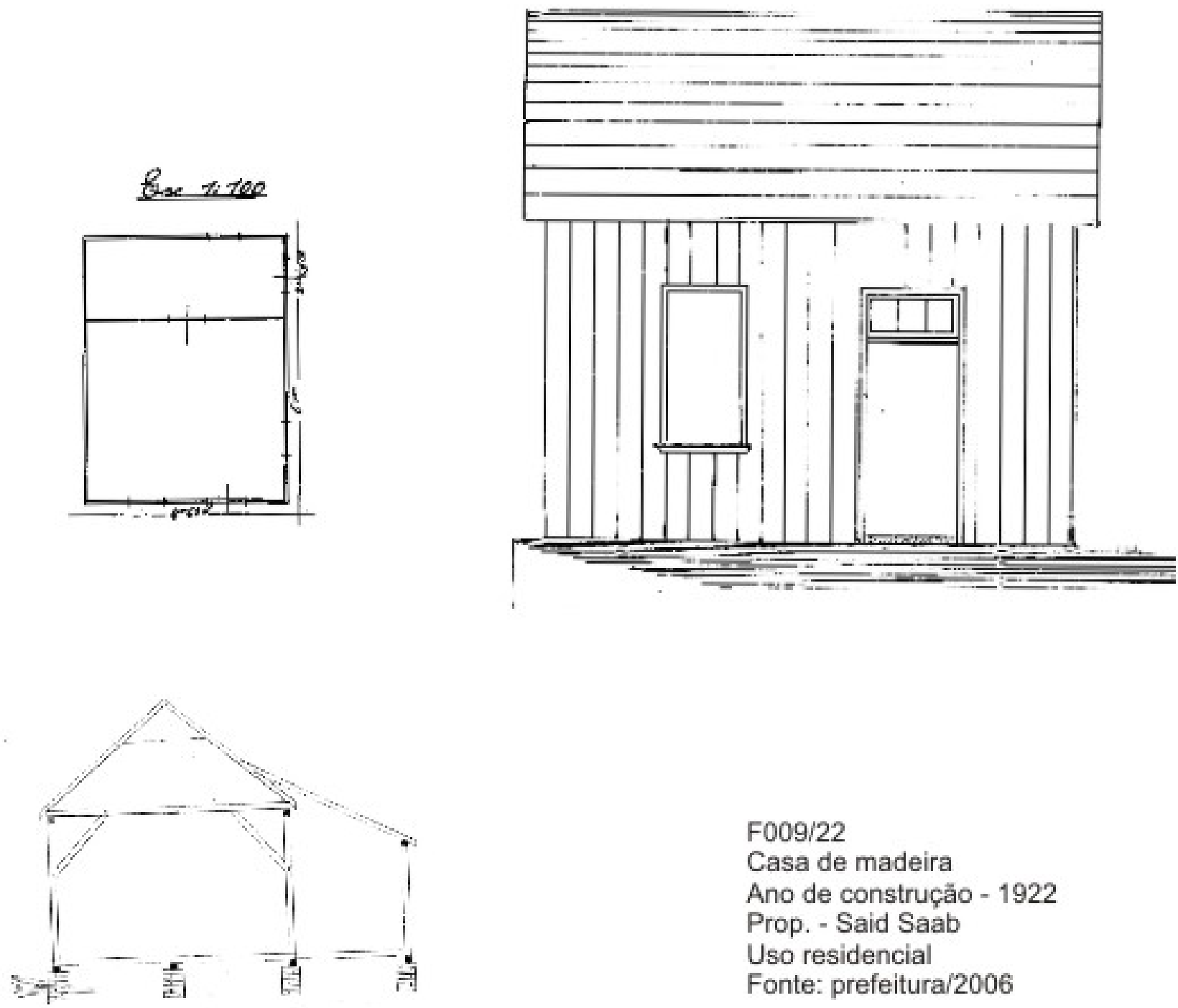

F009/22

Casa de madeira

Ano de construçăo - 1922

Prop. - Said Saab

Uso residencial

Fonte: prefeitura/2006 

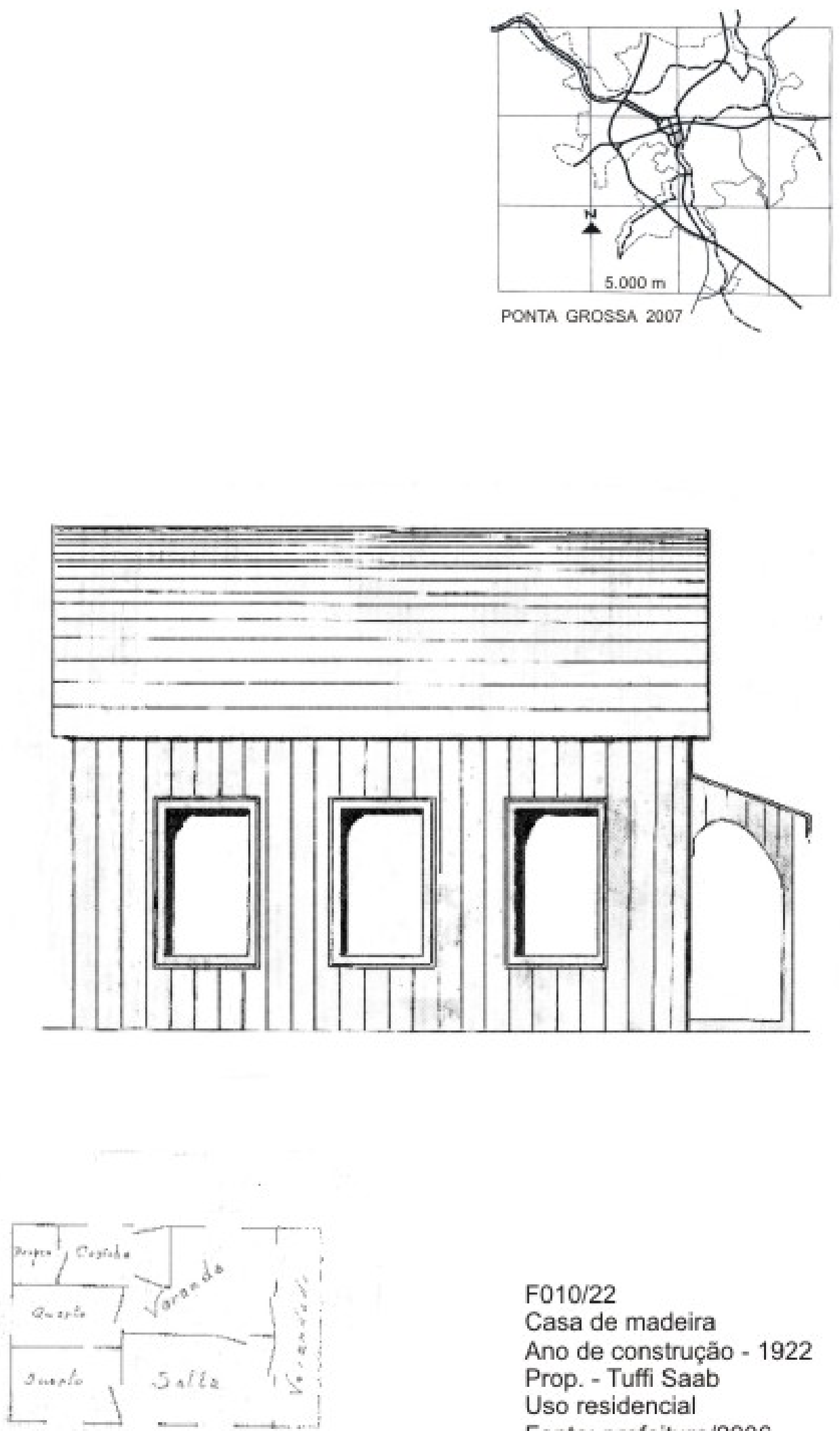

F010/22

Casa de madeira

Ano de construção - 1922

Prop. - Tuffi Saab

Uso residencial

Fonte: prefeitura/2006 

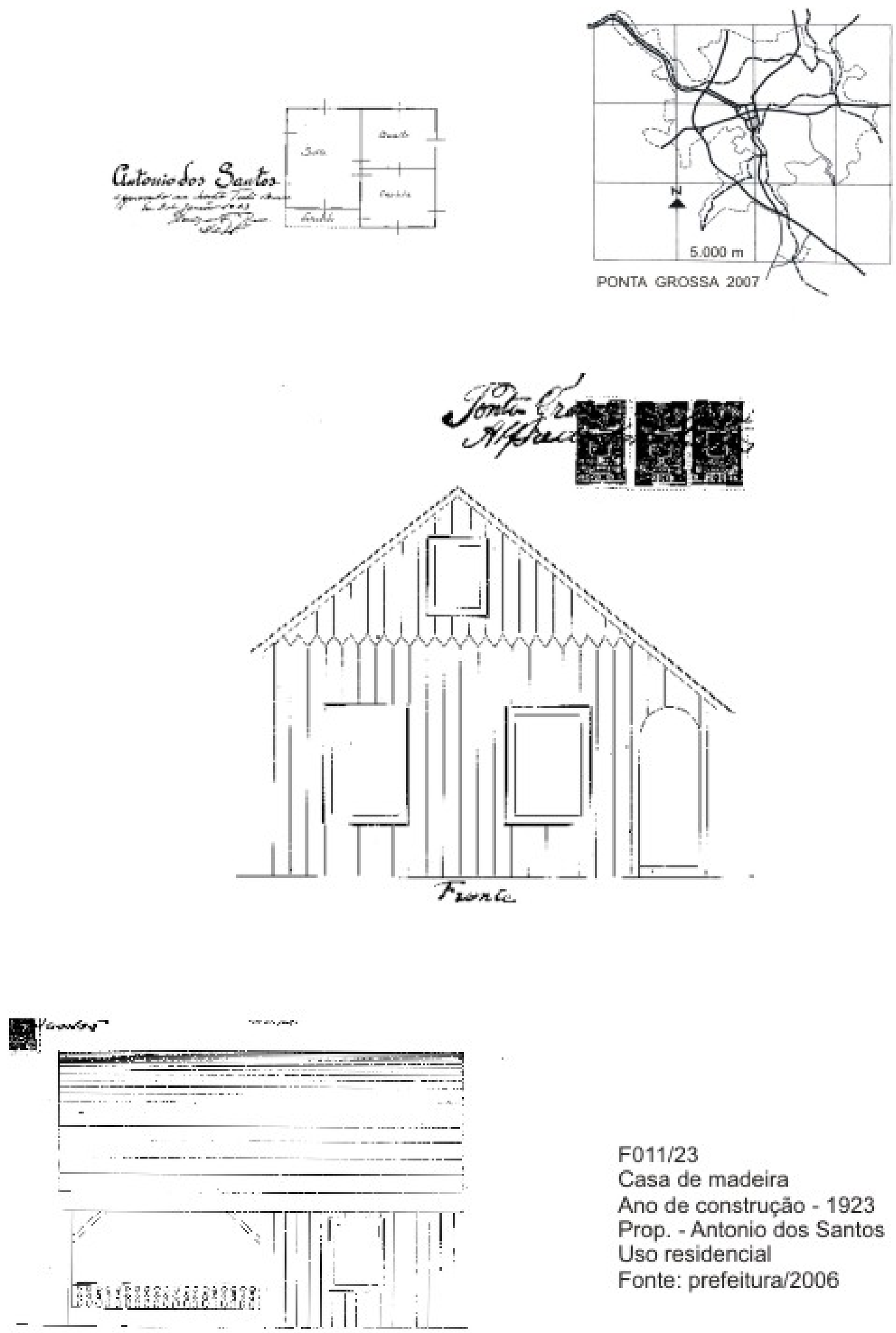

F011/23

Casa de madeira

Ano de construçäo - 1923

Prop. - Antonio dos Santos Uso residencial

Fonte: prefeitura/2006 

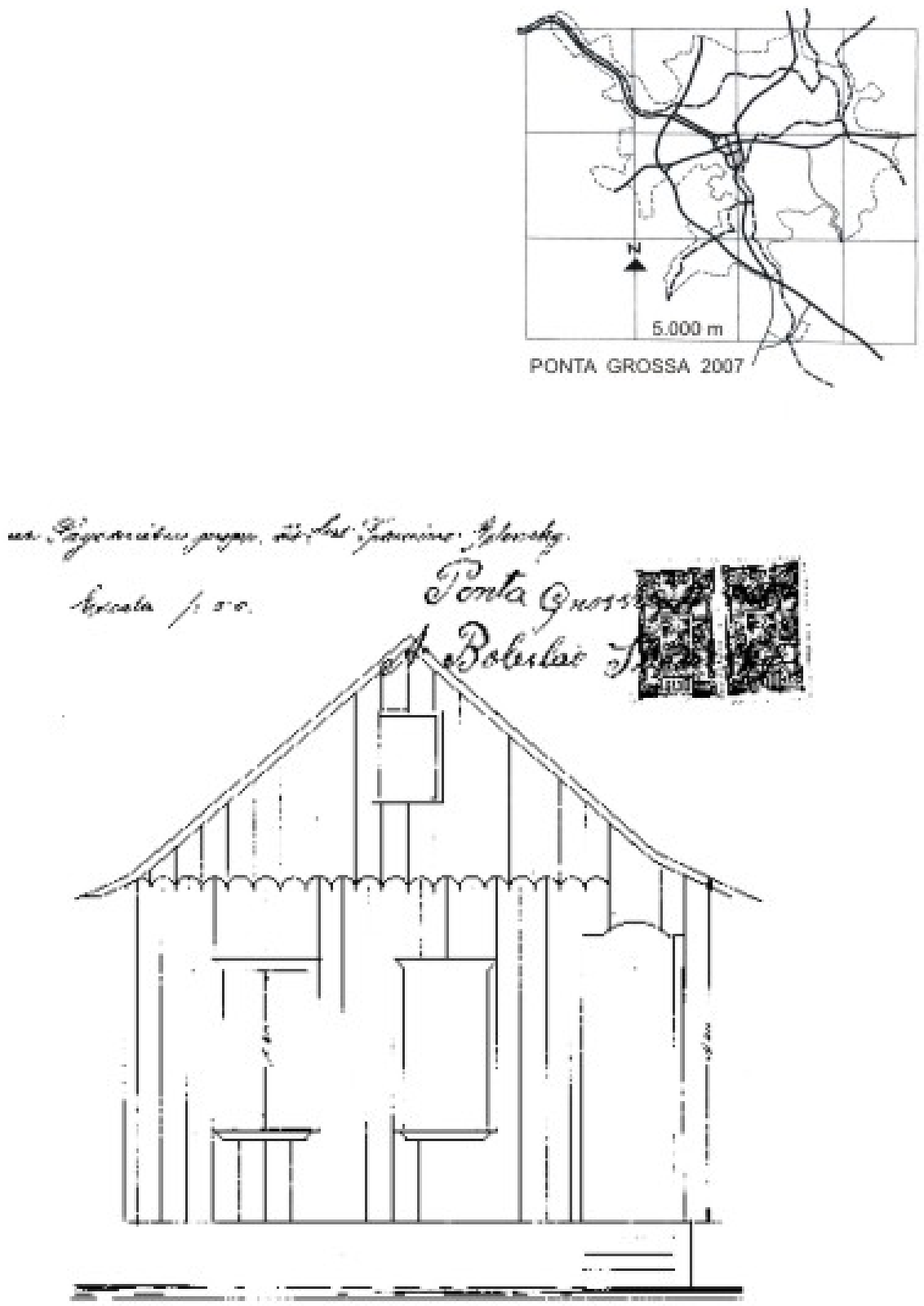

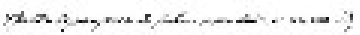

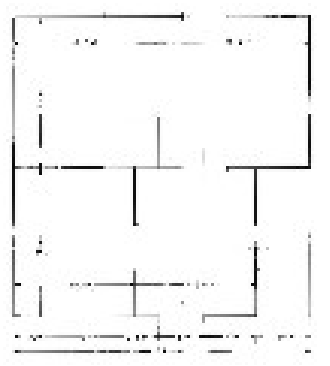

F012/23

Casa de madeira

Ano de construção - 1923

Prop. - Francisco Galinsky

Uso residencial

Fonte: prefeitura/2006 

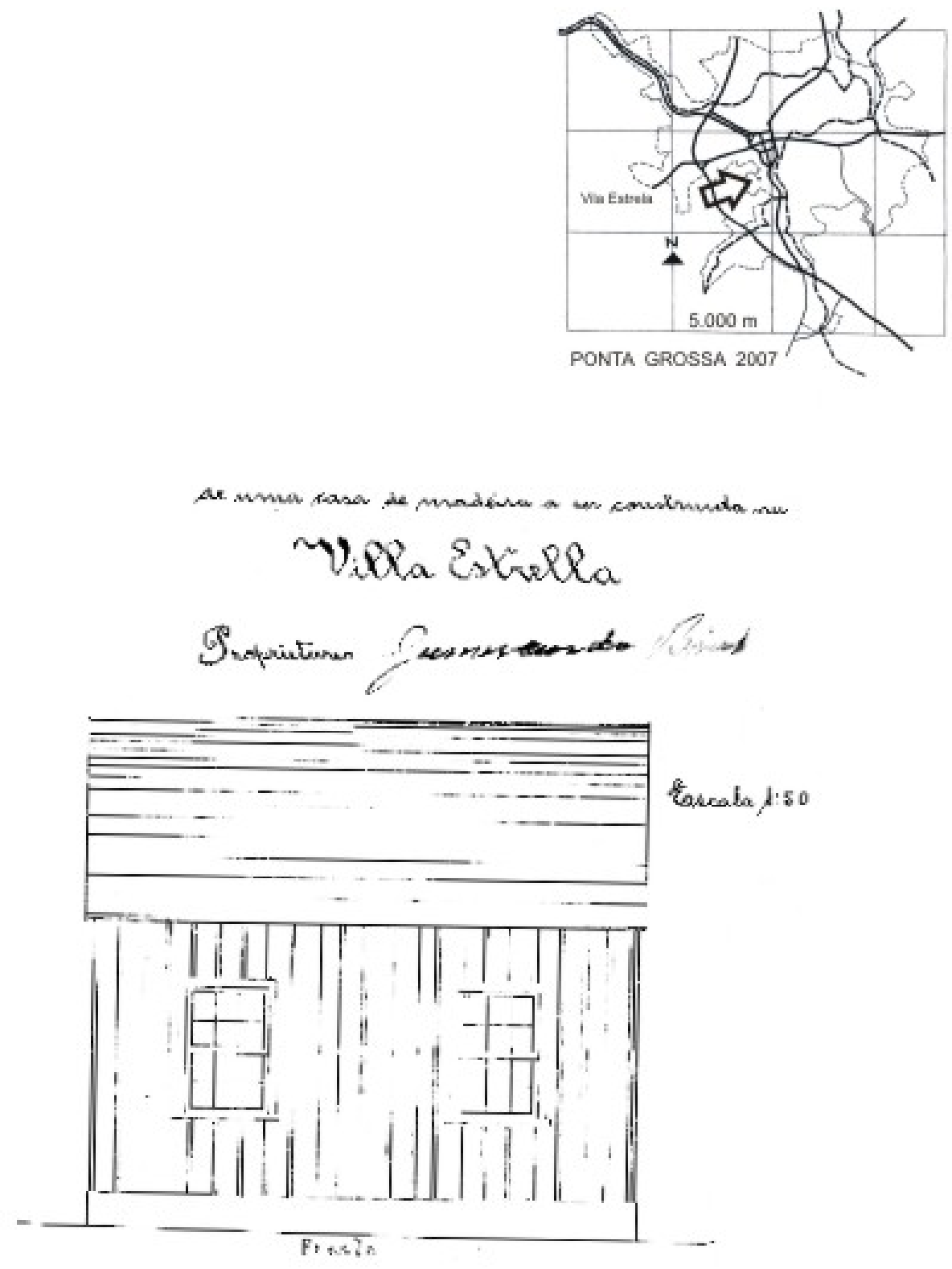

$+\cdots$

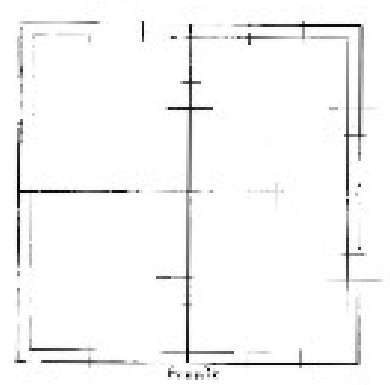

F013/23

Casa de madeira

Ano de construçăo - 1923

Prop. - Gumercindo Bisabo

Uso residencial

Fonte: prefeitura/2006 

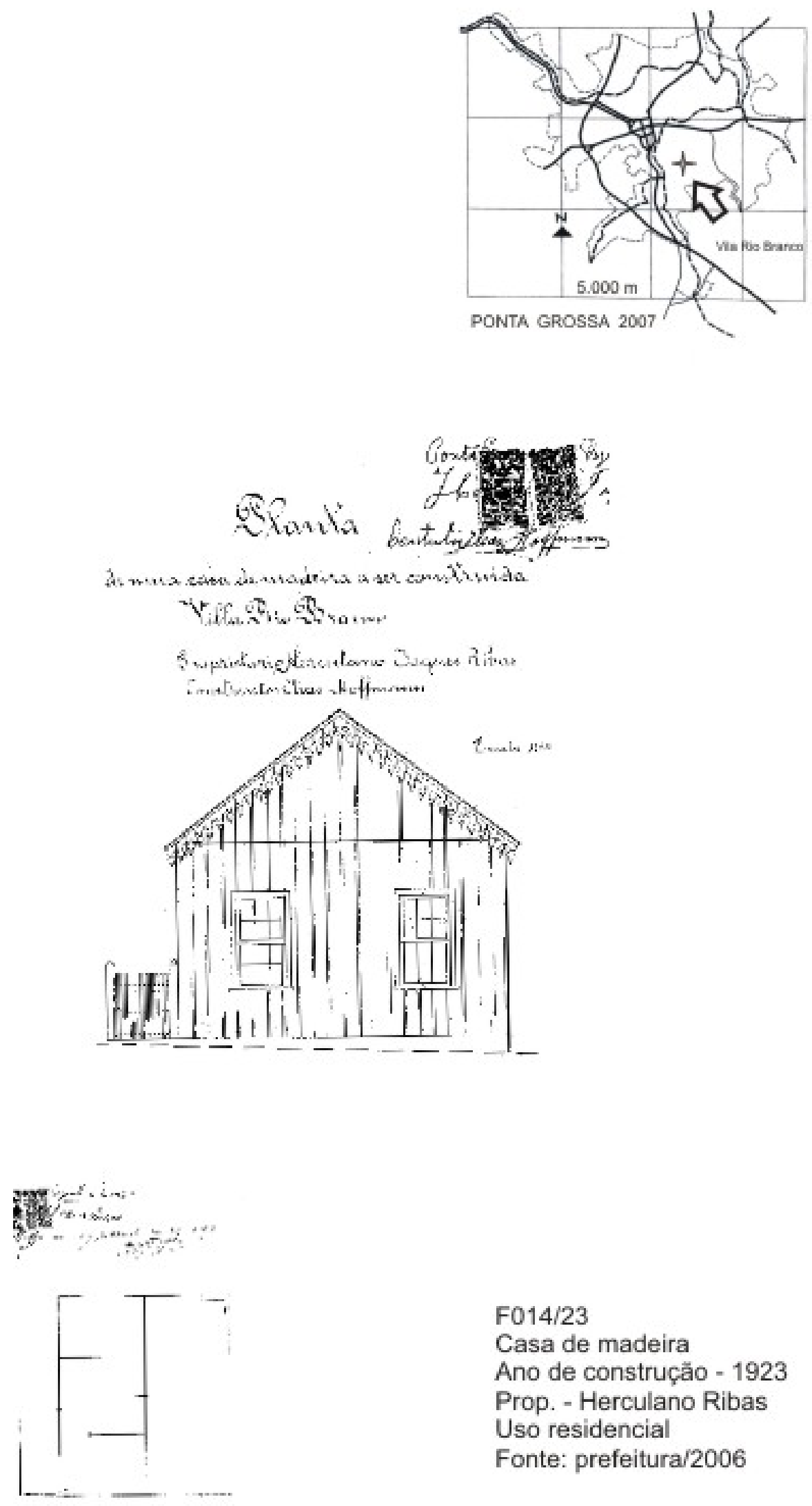

F014/23

Casa de madeira

Ano de construçăo - 1923

Prop. - Herculano Ribas

Uso residencial

Fonte: prefeitura/2006 

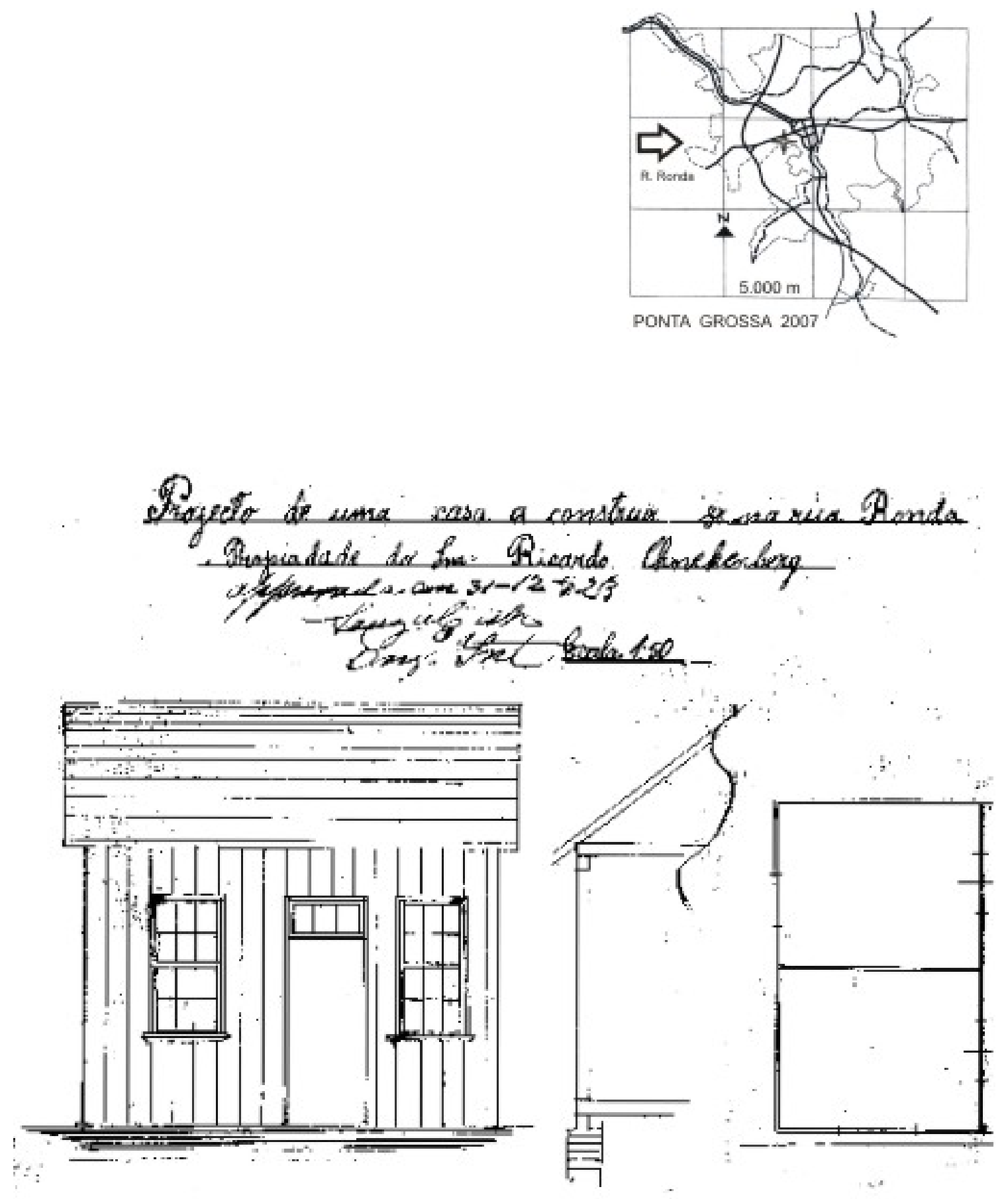

F015/23

Casa de madeira

Ano de construçăo - 1923

Prop. - Ricardo Chnekenberg Uso residencial

Fonte: prefeitura/2006 

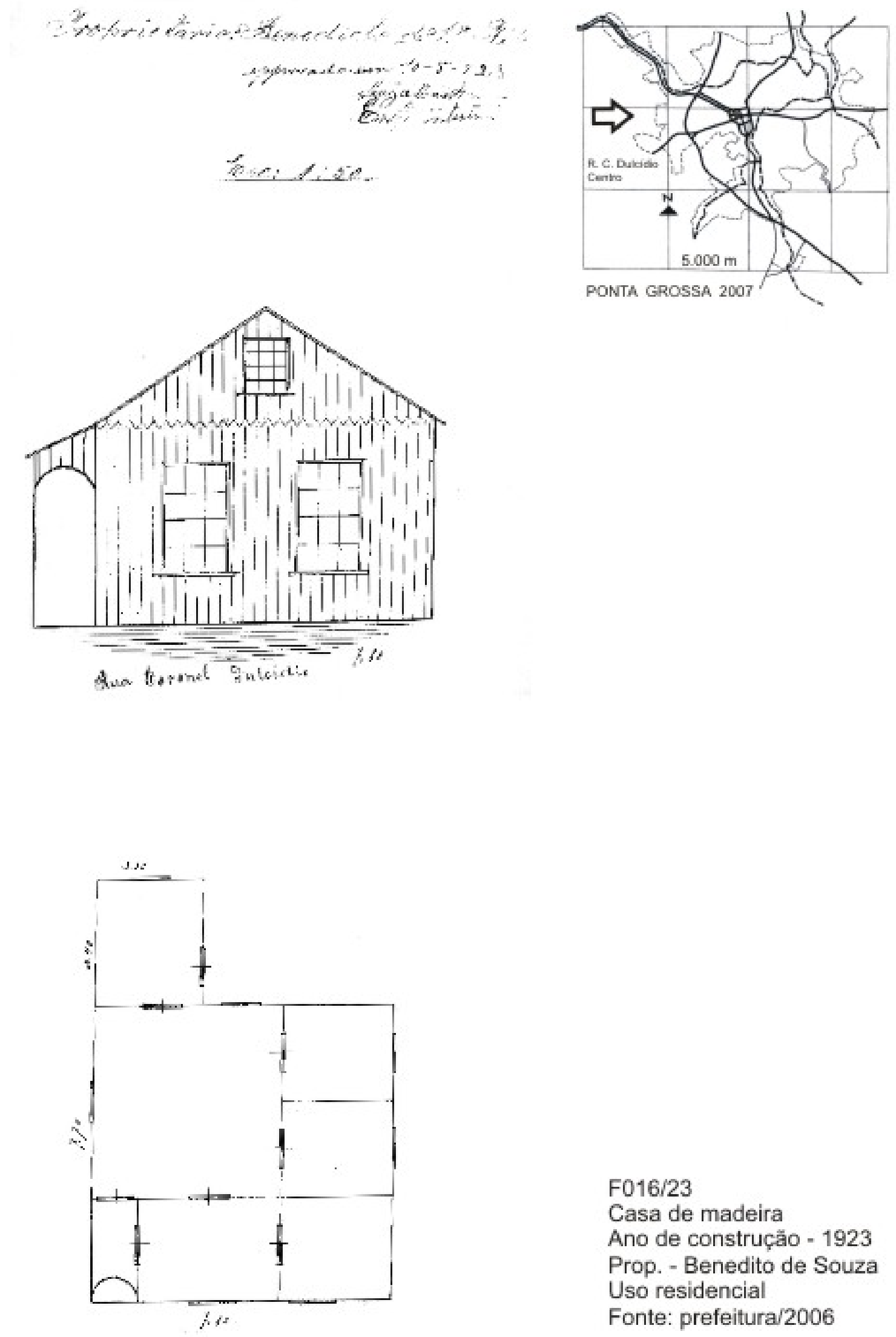

F016/23

Casa de madeira

Ano de construção - 1923

Prop. - Benedito de Souza

Uso residencial

Fonte: prefeitura/2006 

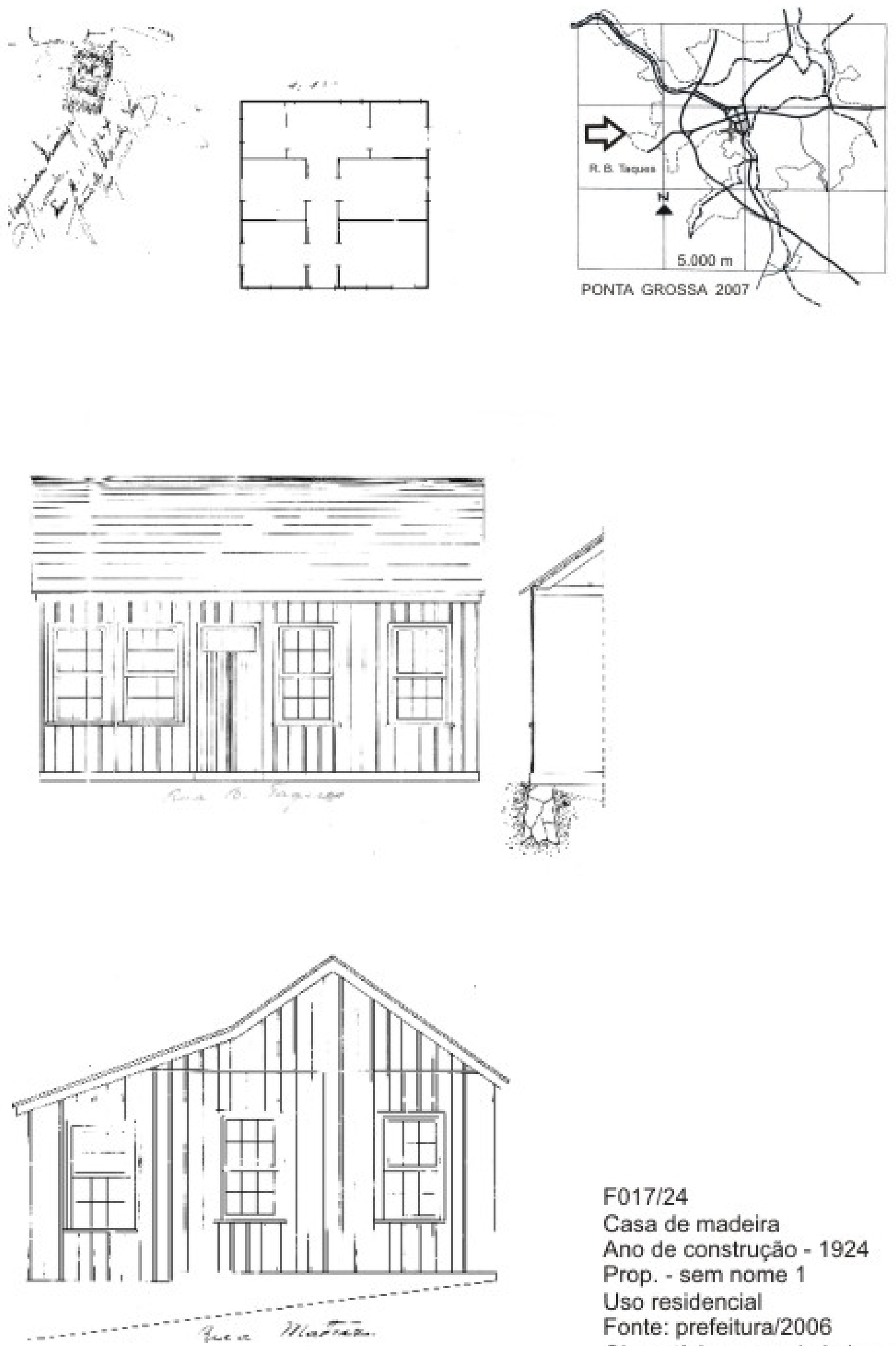

F017/24

Casa de madeira

Ano de construçăo - 1924

Prop. - sem nome 1

Uso residencial

Fonte: prefeitura/2006

Obs. - típica casa da imigraçăo 

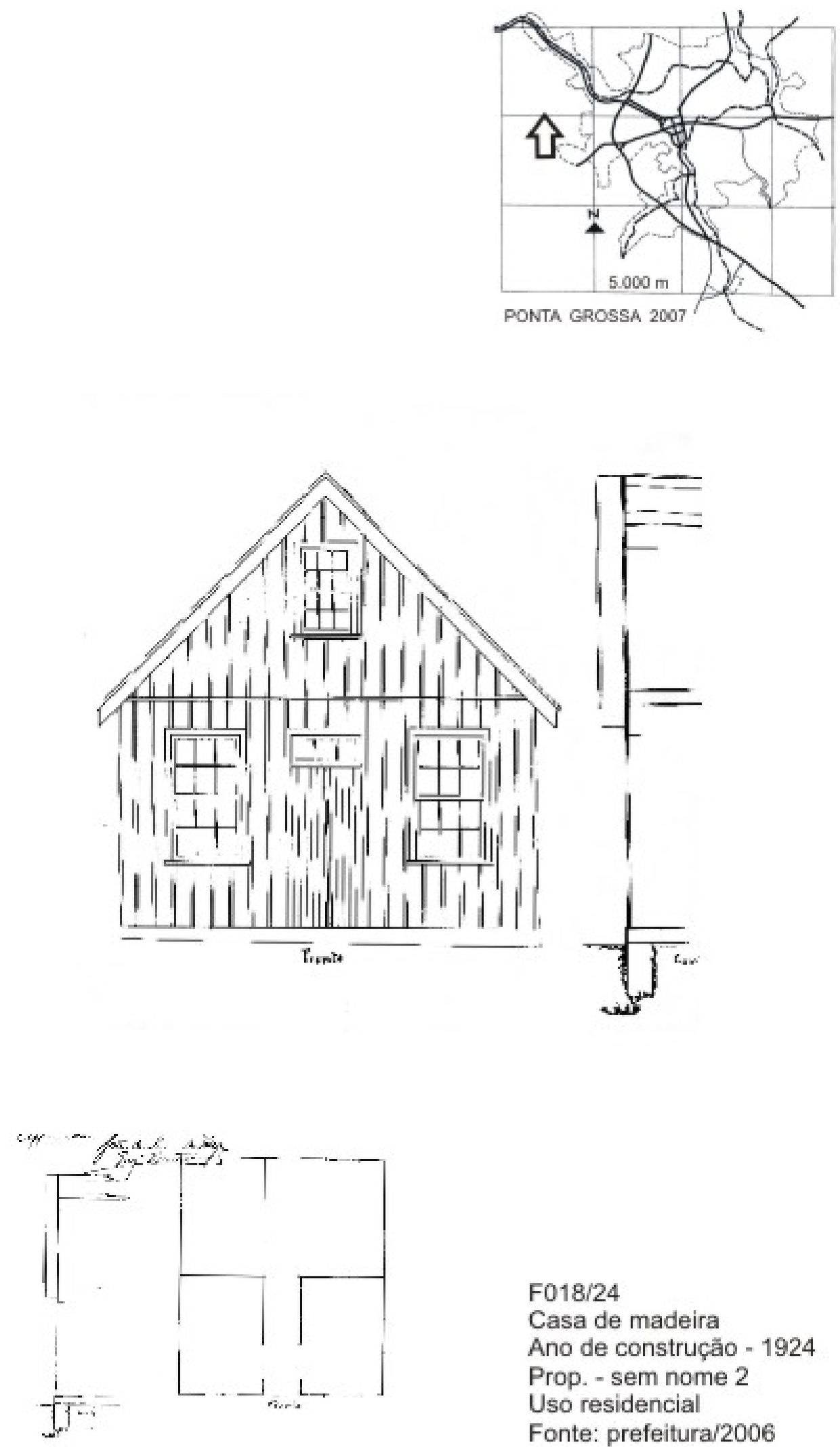

F018/24

Casa de madeira

Ano de construçäo - 1924

Prop. - sem nome 2

Uso residencial

Fonte: prefeitura/2006

Obs. - típica implantação

longitudinal 

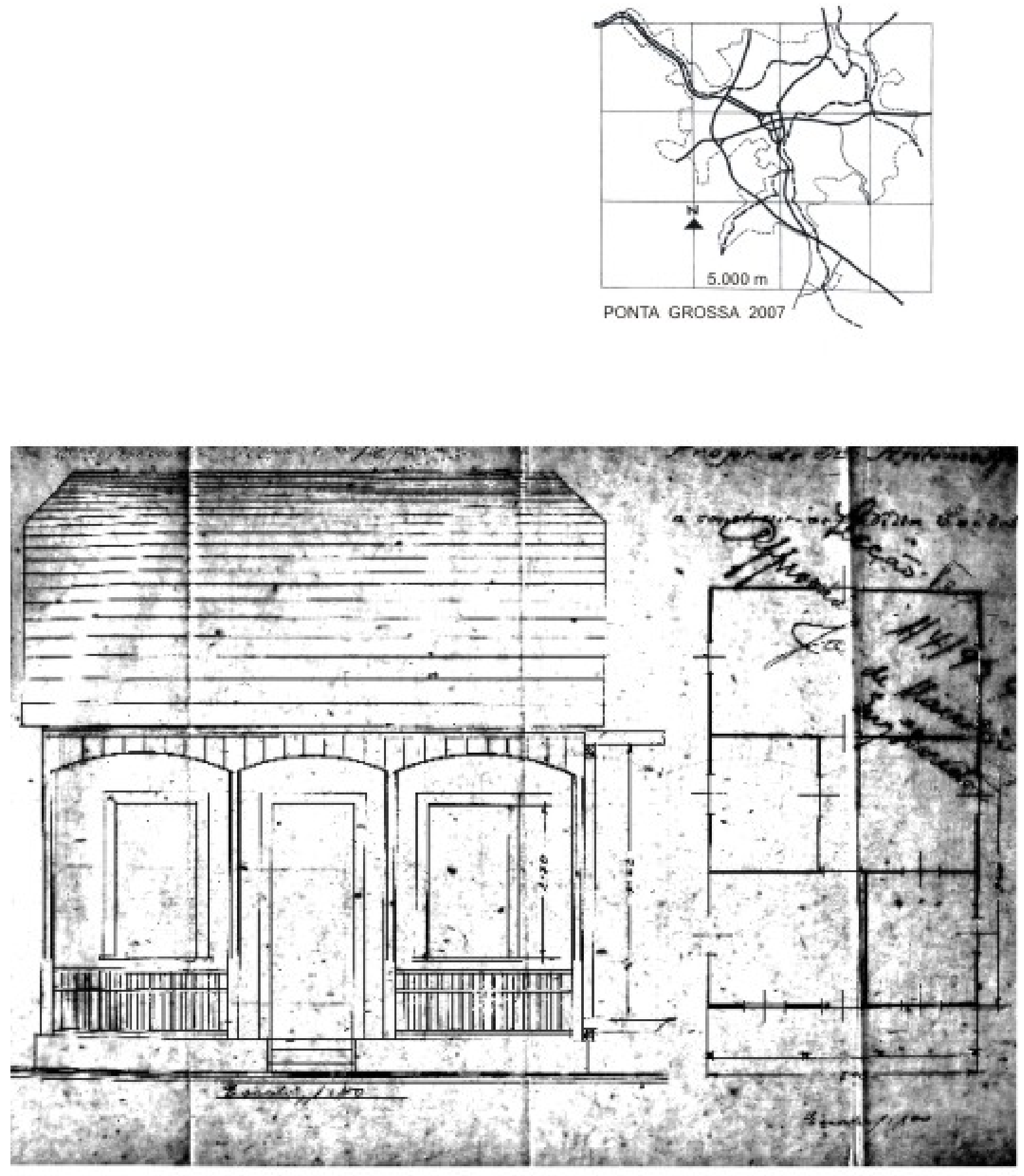

F019/24

Casa de madeira

Ano de construção - 1924

Prop. - Antonio Medeiros

Uso residencial

Fonte: prefeitura/2006 

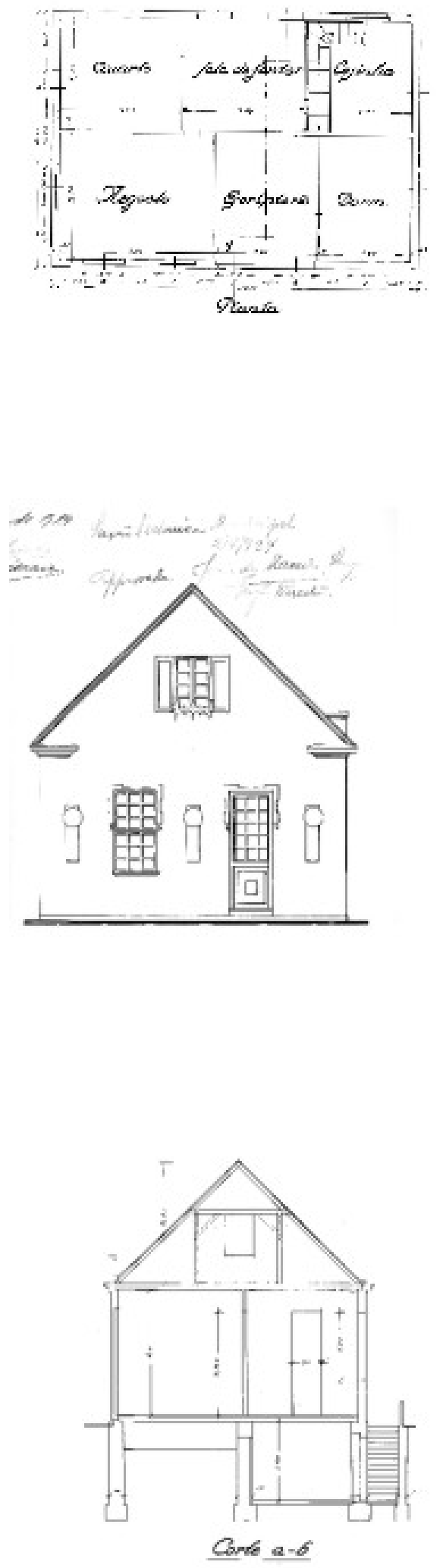
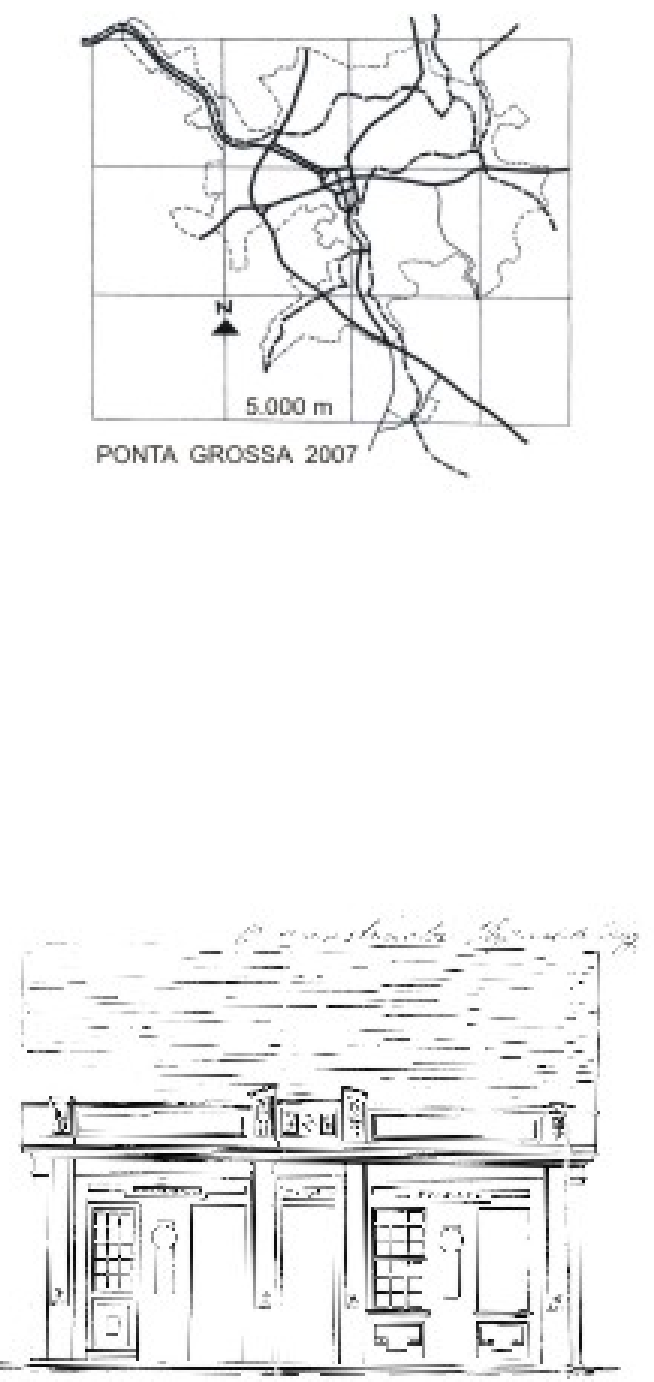

F020/24

Casa de madeira mista Ano de construçäo - 1924

Prop. - Augusto Cavagnari Sobrinho Uso residencial e comercial Fonte: prefeitura/2006 Obs. - Características de transição da implantação colonial e do chalé eclético 

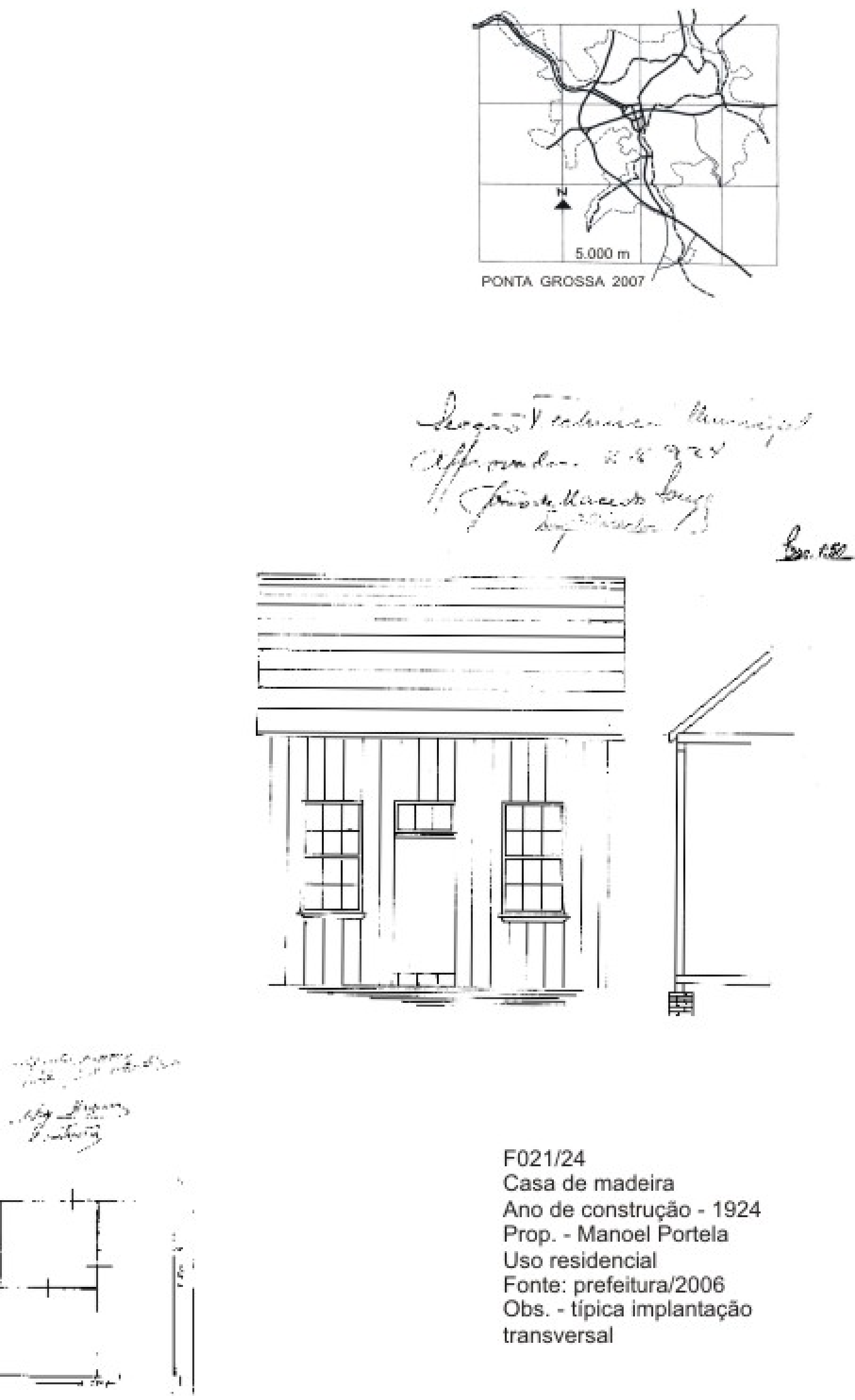

F021/24

Casa de madeira

Ano de construção - 1924

Prop. - Manoel Portela

Uso residencial

Fonte: prefeitura/2006

Obs. - típica implantação

transversal 

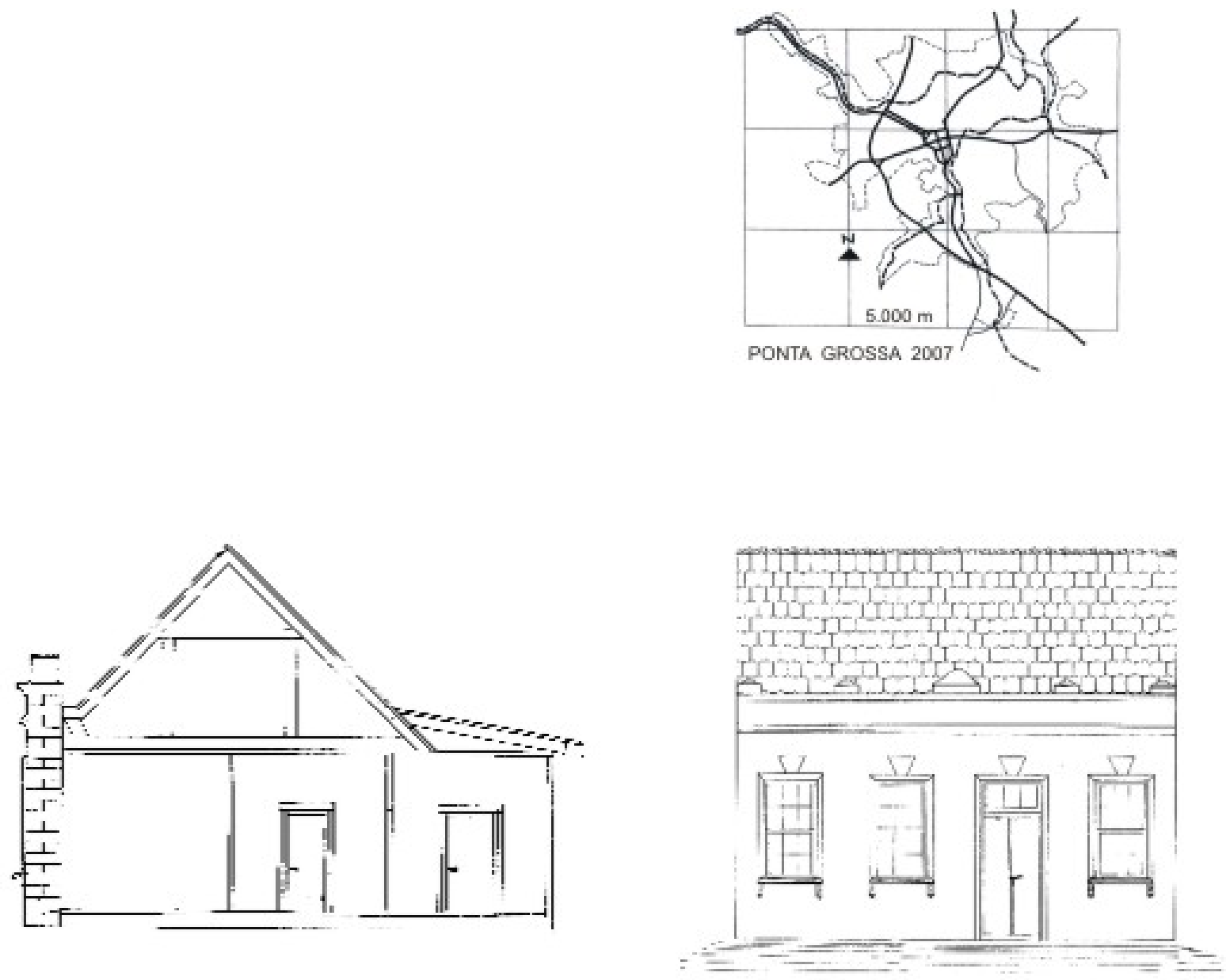

Esc $-t o t$

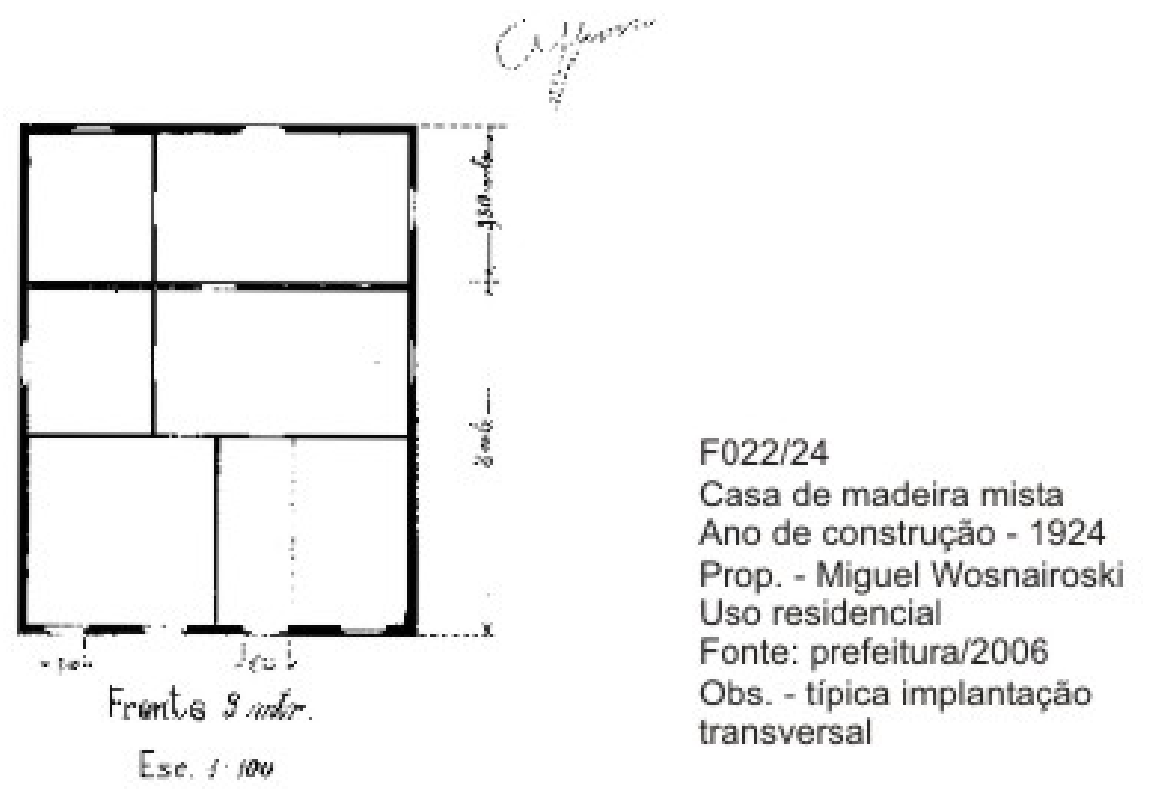



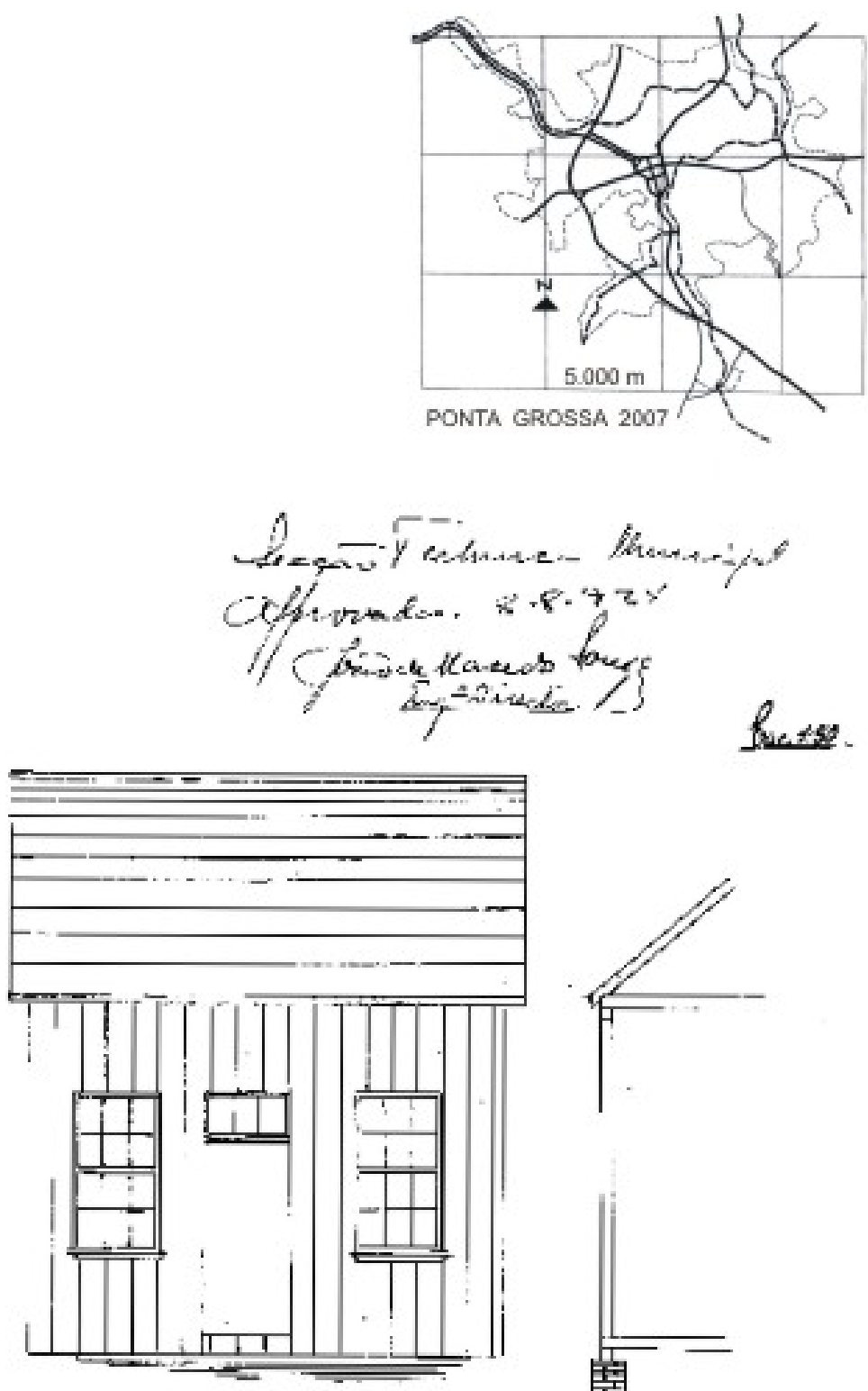

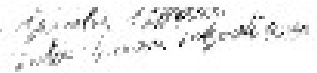

$26 x$ Hen

$4 \operatorname{mat} 25$

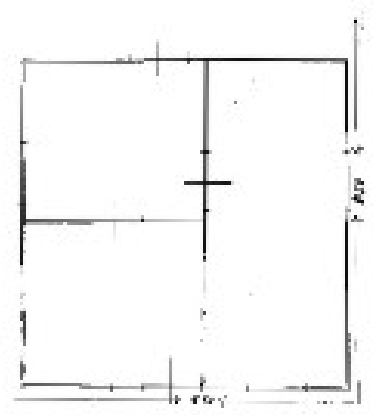

F023/24

Casa de madeira

Ano de construçäo - 1924

Prop. - sem nome 3

Uso residencial

Fonte: prefeitura/2006 

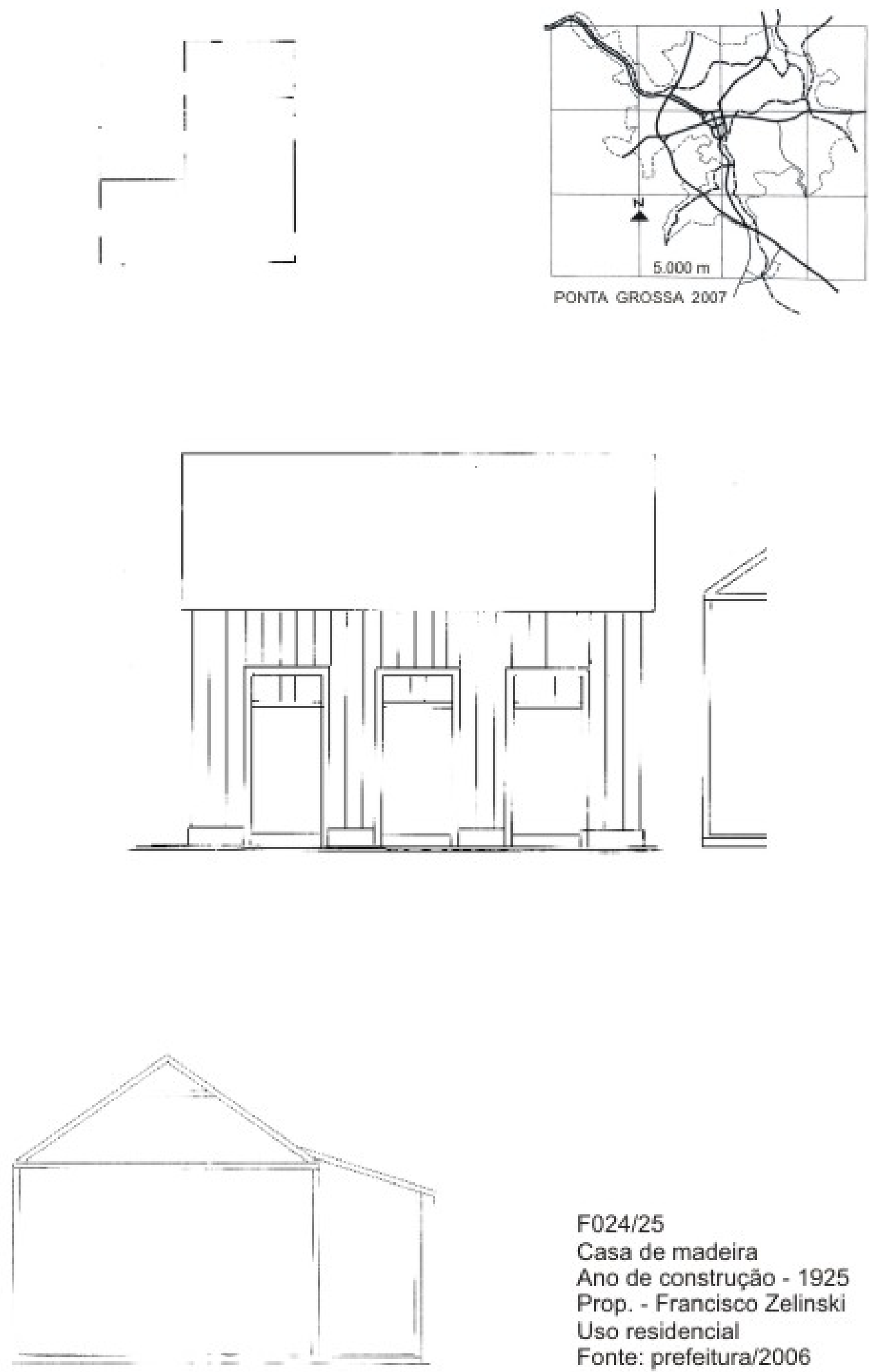

F024/25

Casa de madeira

Ano de construçăo - 1925

Prop. - Francisco Zelinski

Uso residencial

Fonte: prefeitura/2006 

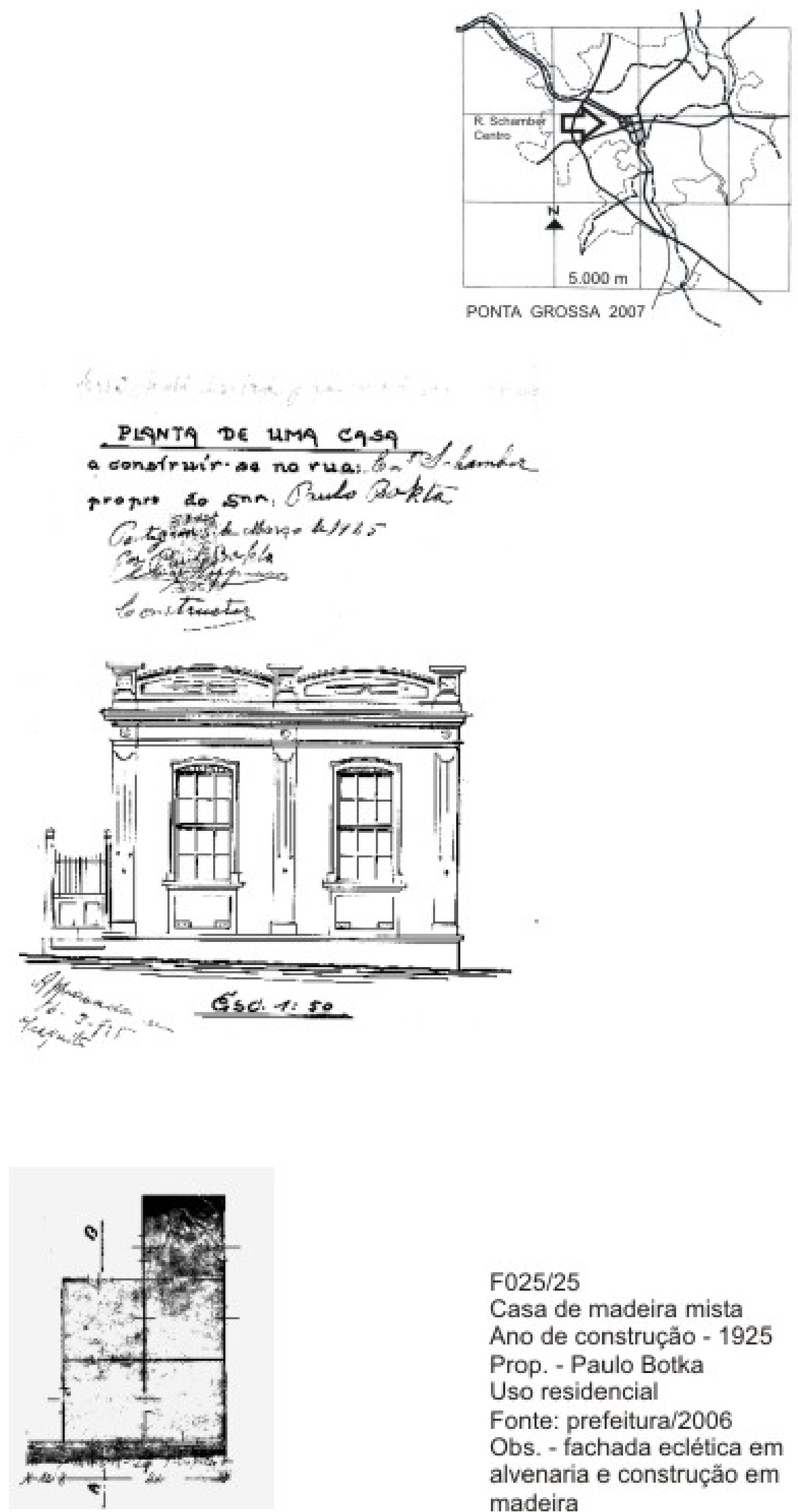

F025/25

Casa de madeira mista

Ano de construçăo - 1925

Prop. - Paulo Botka

Uso residencial

Fonte: prefeitura/2006

Obs. - fachada eclética em alvenaria e construção em madeira 

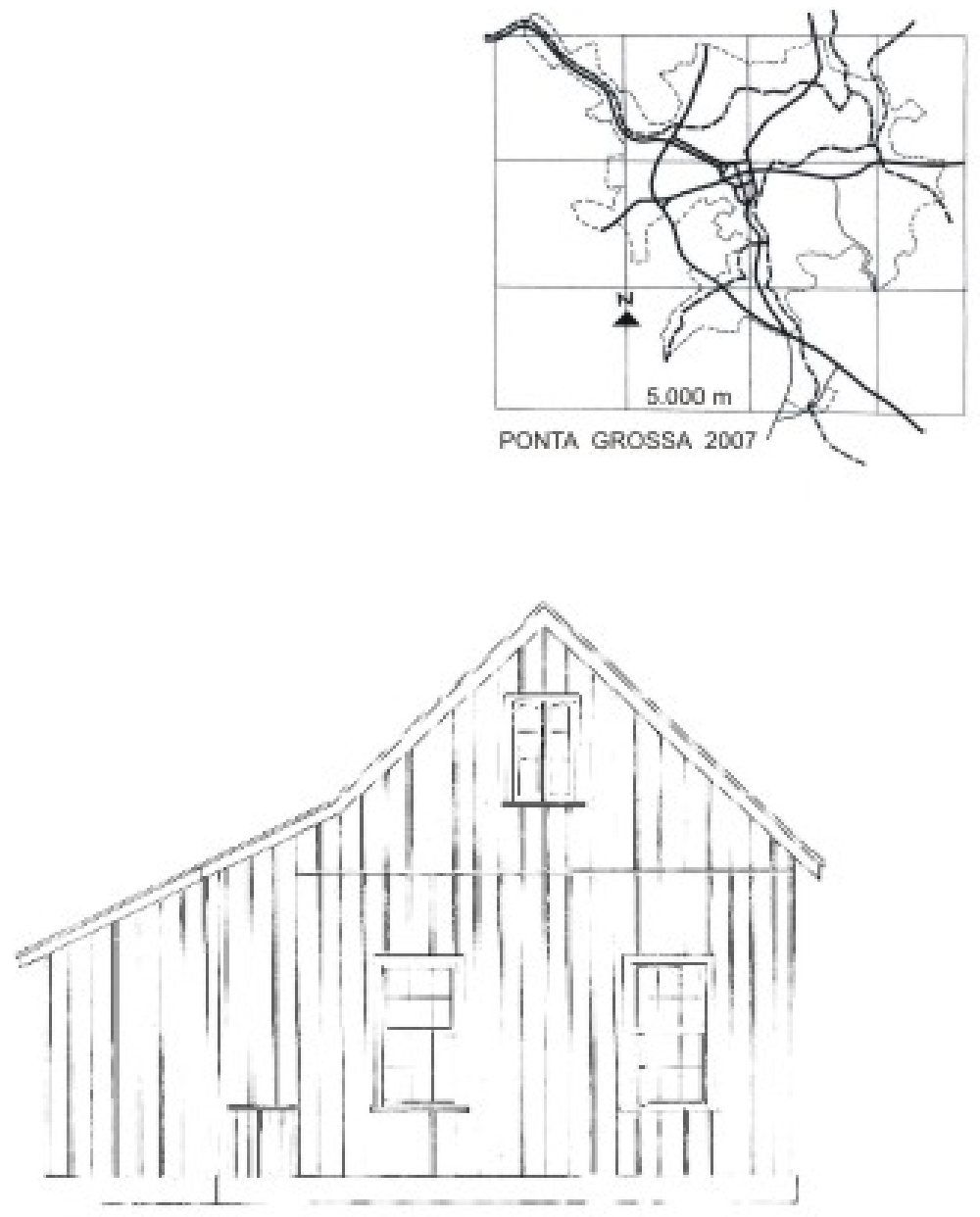

Af, dy 15

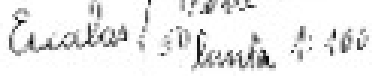

ᄂ

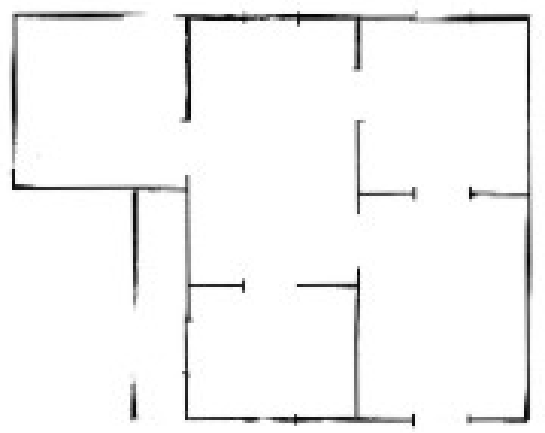

F026/27

Casa de madeira

Ano de construçäo - 1927

Prop. - Cepestriano Cabrini Uso residencial

Fonte: prefeitura/2006 

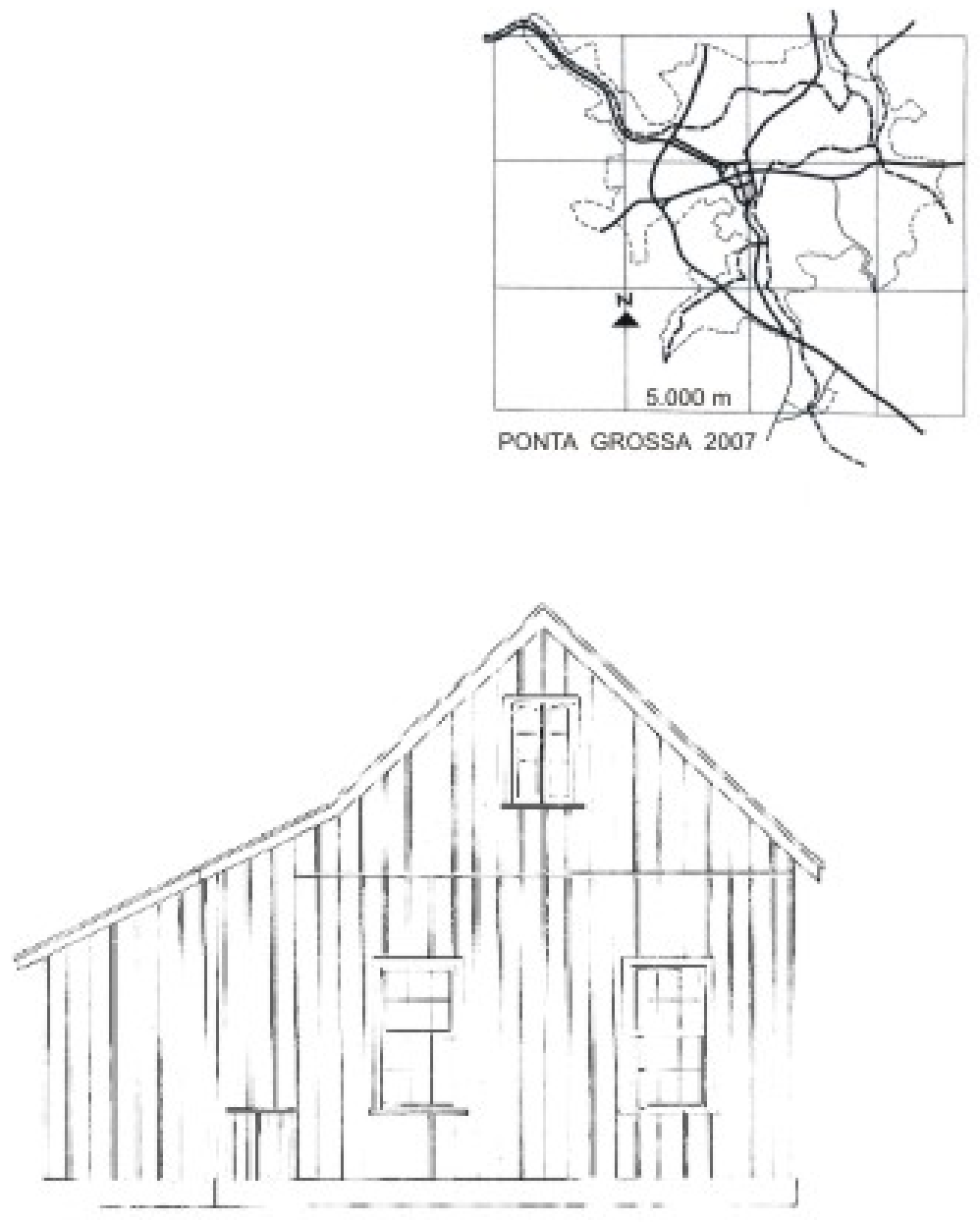

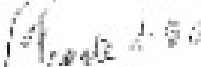

Euatos tosia 1406

ᄂ

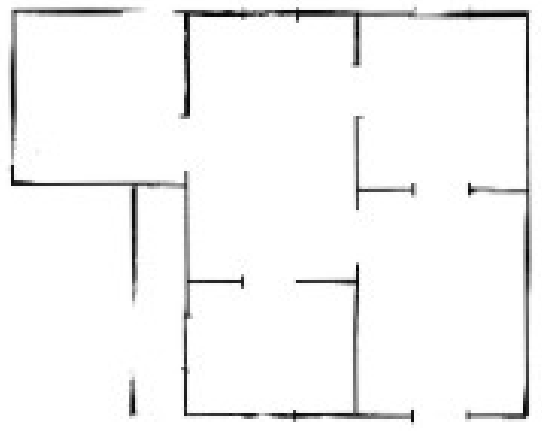

F026/27

Casa de madeira

Ano de construçäo - 1927

Prop. - Cepestriano Cabrini Uso residencial

Fonte: prefeitura/2006 

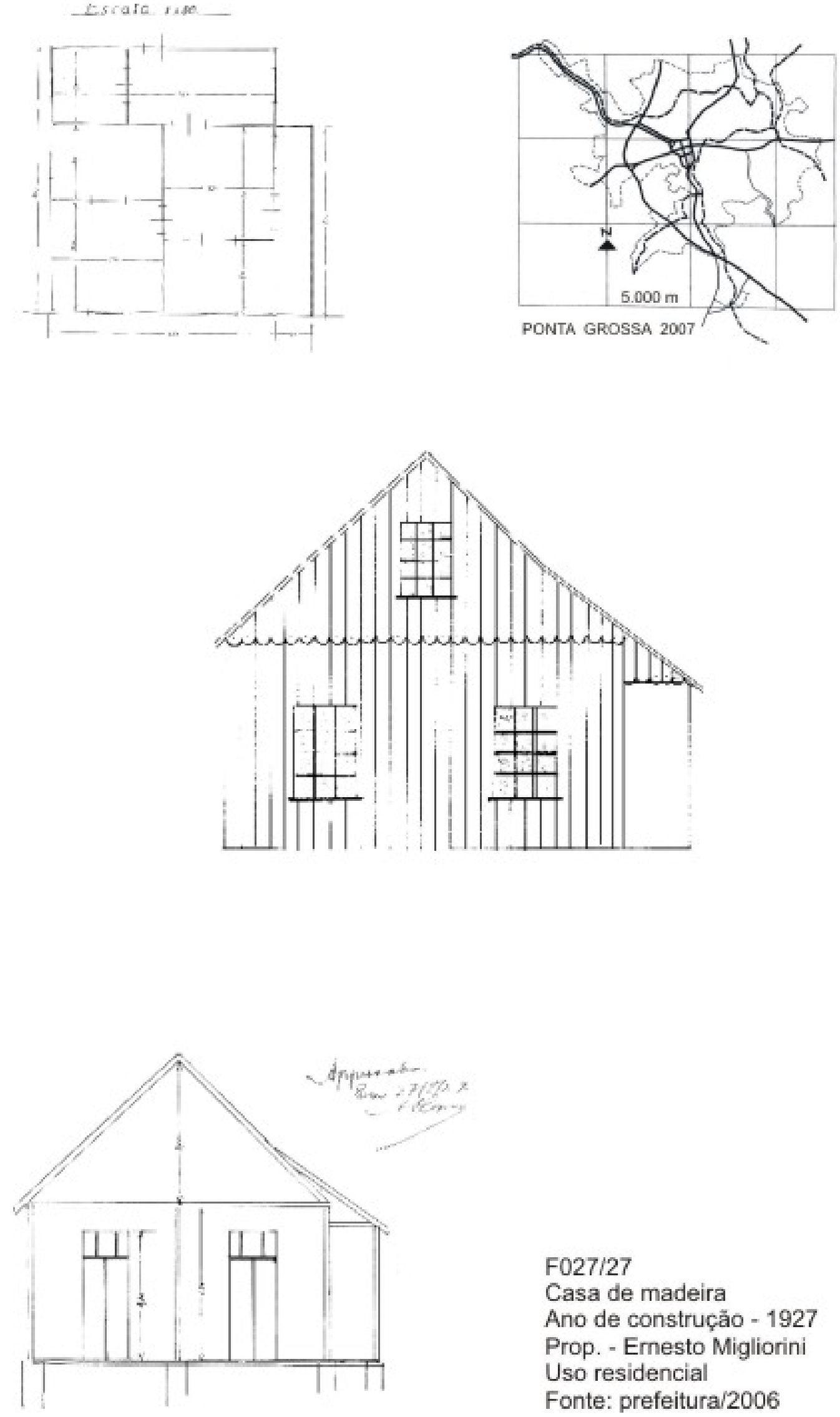

F027/27

Casa de madeira

Ano de construçăo - 1927

Prop. - Emesto Migliorini

Uso residencial

Fonte: prefeitura/2006 

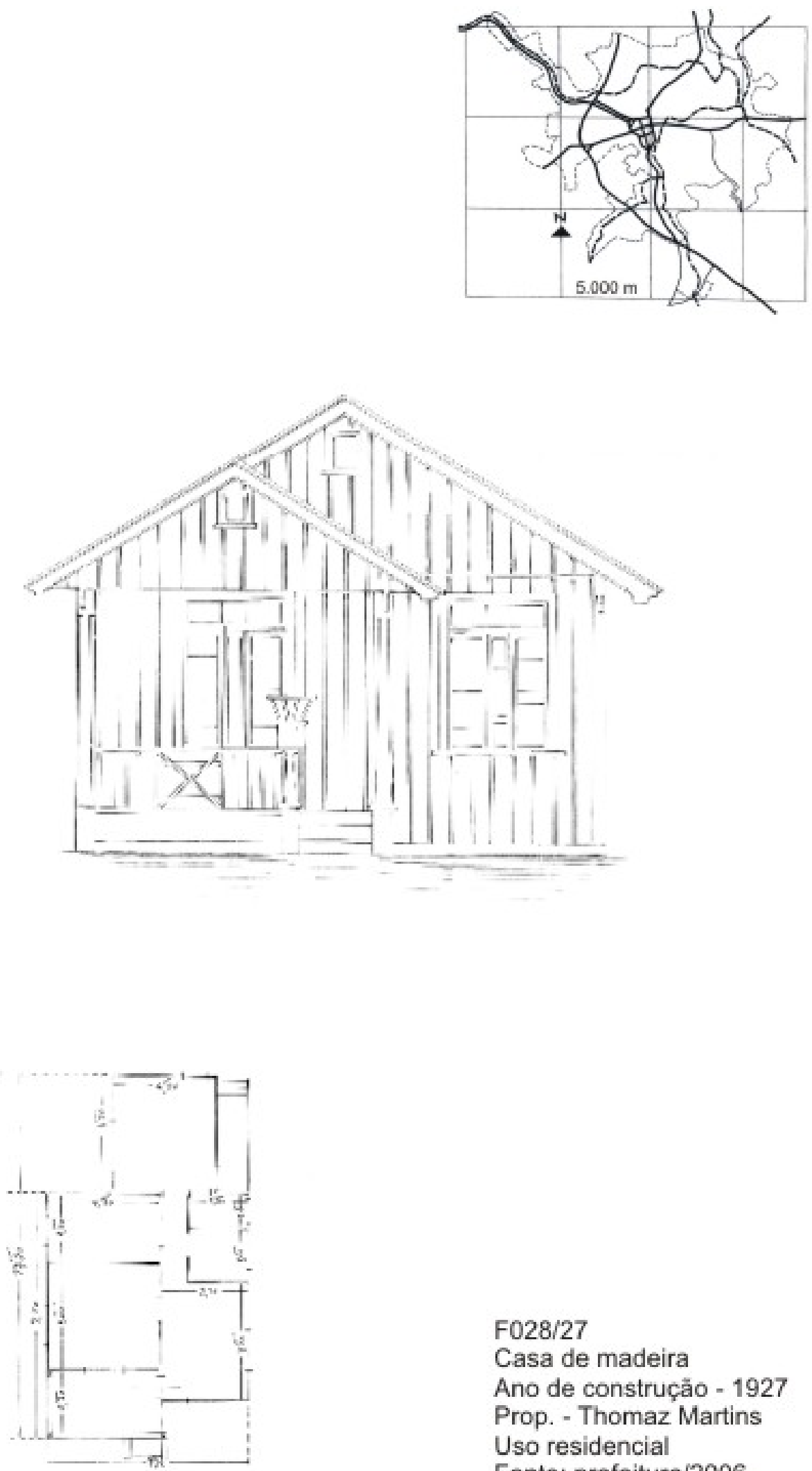

F028/27

Casa de madeira Ano de construção - 1927

Prop. - Thomaz Martins Uso residencial

Fonte: prefeitura/2006 


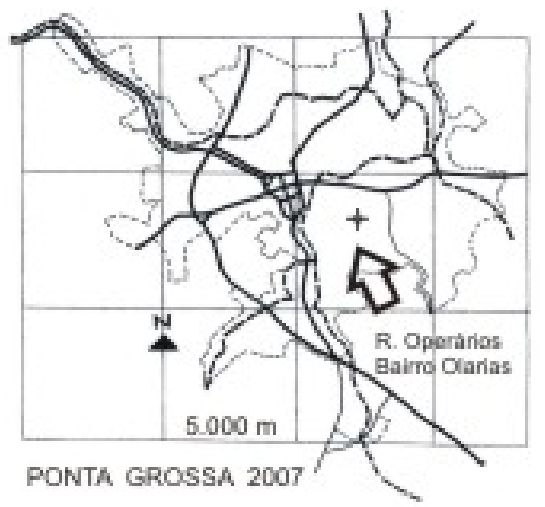

PROJECTO DE UMA CFASA PARA SER CONBTRLIOA NO

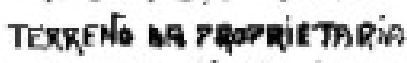

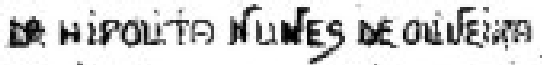
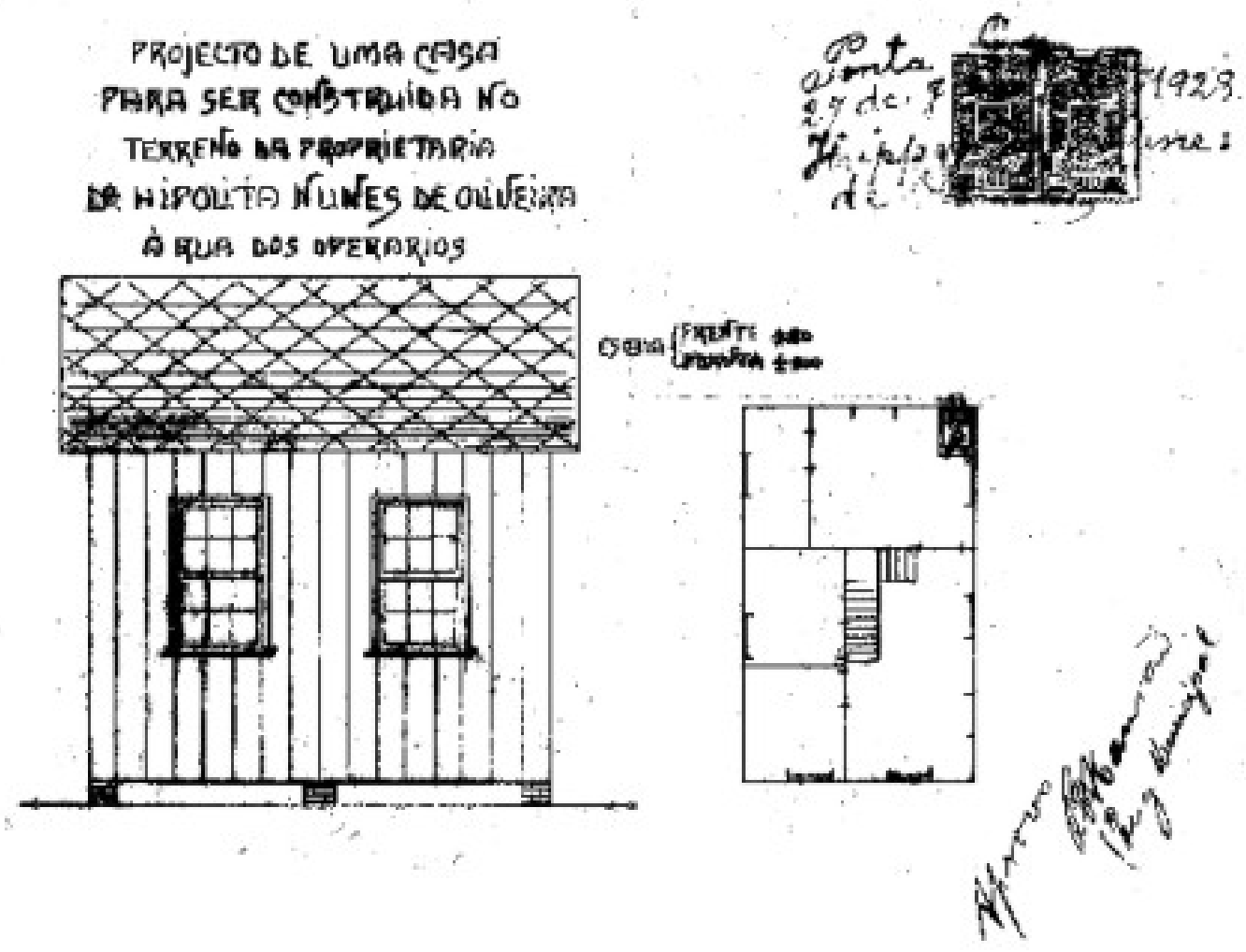

F029/27

Casa de madeira

Ano de construção - 1927

Prop. - Hipólita de Oliveira Uso residencial

Fonte: prefeitura/2006 

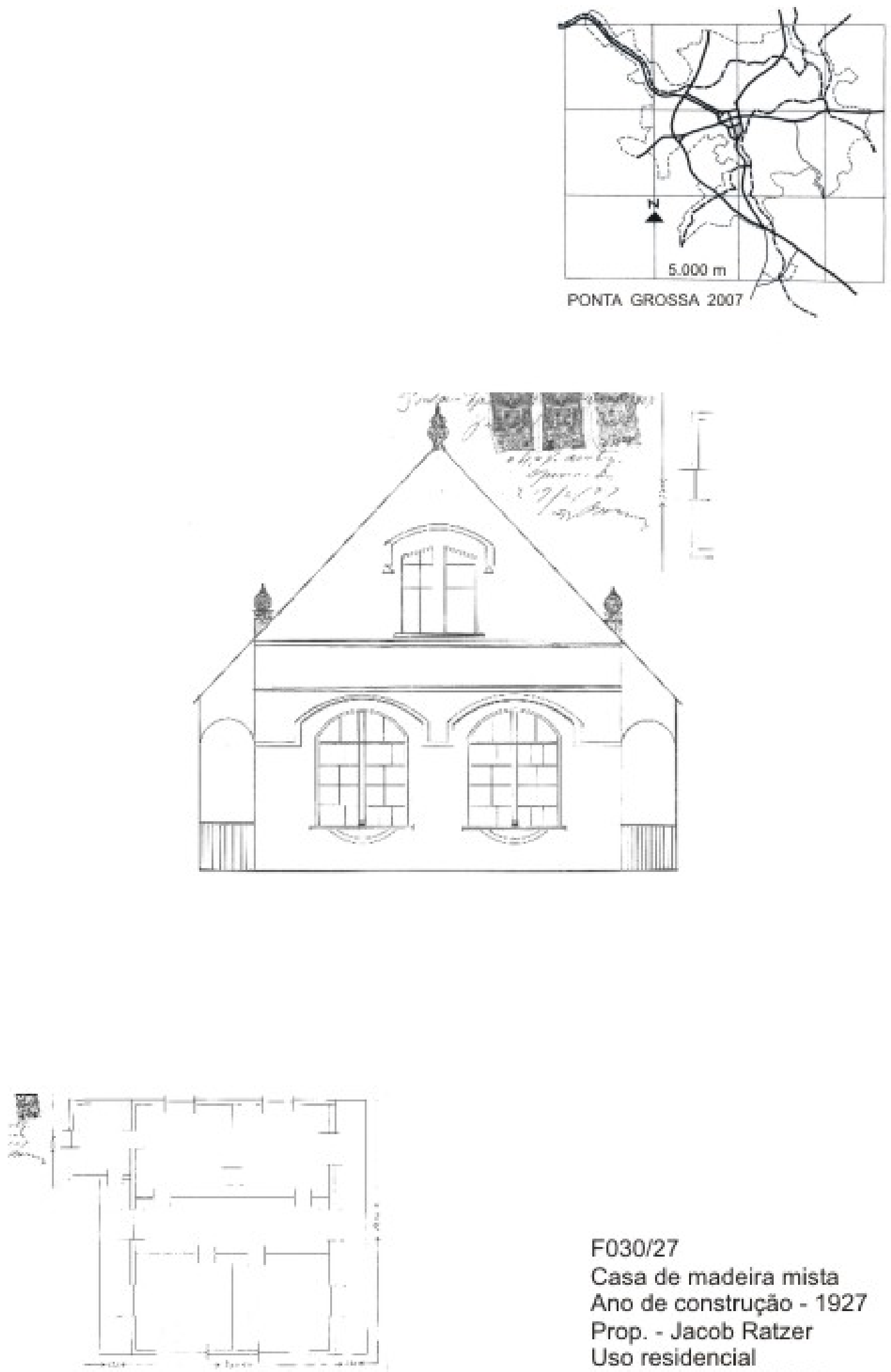

F030/27

Casa de madeira mista

Ano de construçăo - 1927

Prop. - Jacob Ratzer

Uso residencial

Fonte: prefeitura/2006

Obs. - fachada eclética 

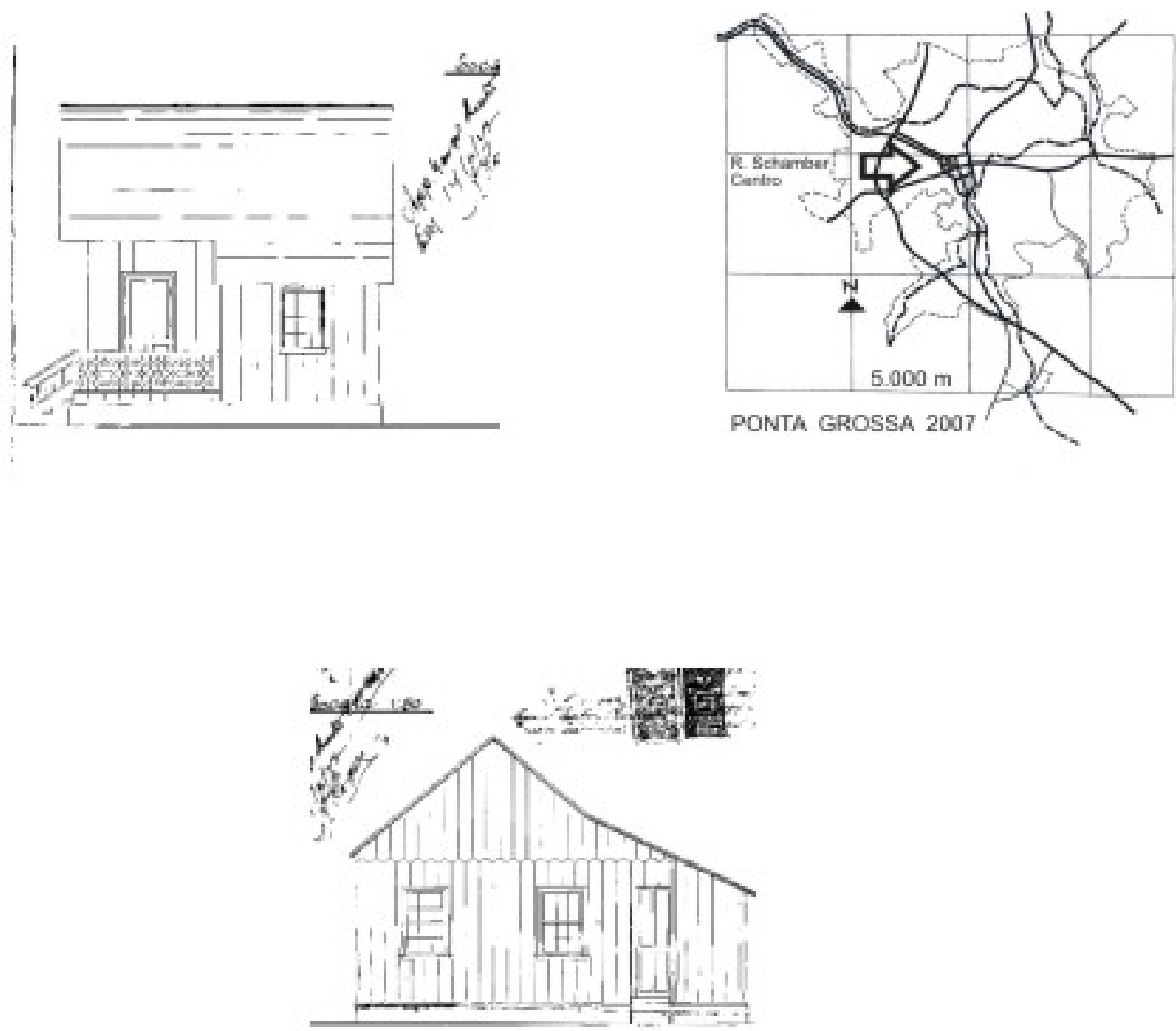

\section{elzojecto}

de muna aroo de madsisa para ose sonotzuida ana sua Gug Sxbannfos eleppriadade do Swe Ruia Goncaloo

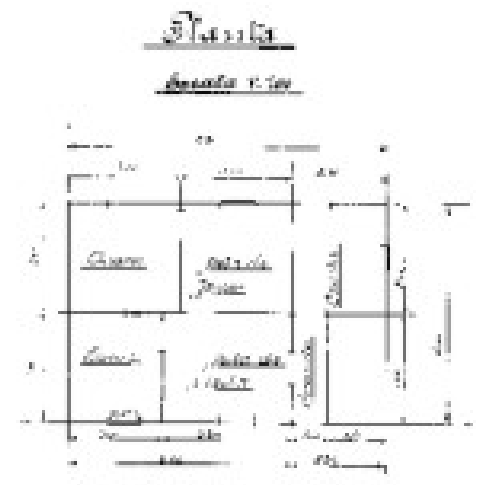

$\mathrm{F} 031 / 27$

Casa de madeira

Ano de construçăo - 1927

Prop. - Luis Gonçalves

Uso residencial

Fonte: prefeitura/2006 

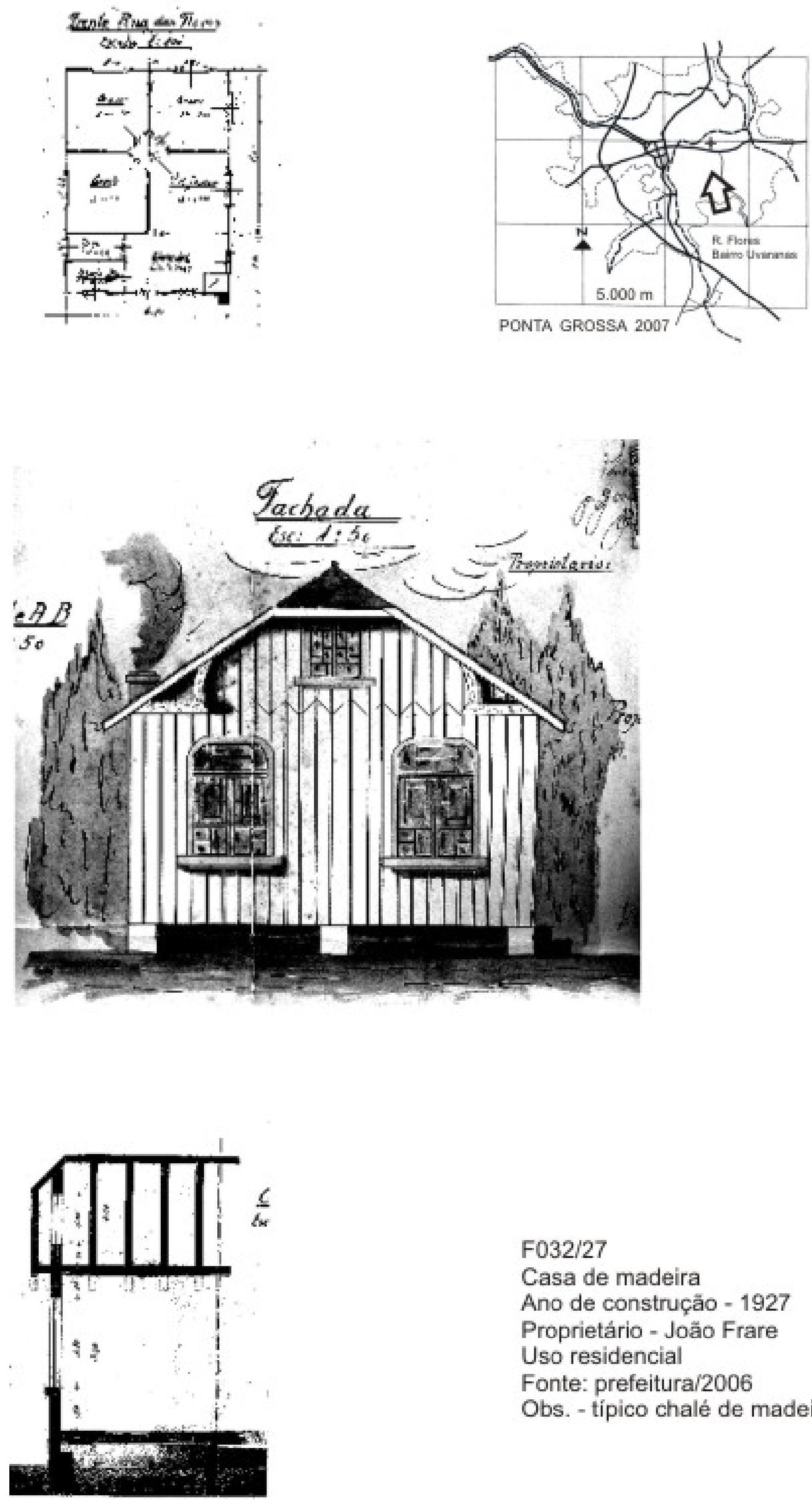

$\mathrm{F} 032 / 27$

Casa de madeira

Ano de construção - 1927

Proprietário - Joăo Frare

Uso residencial

Fonte: prefeitura/2006

Obs. - típico chalé de madeira 

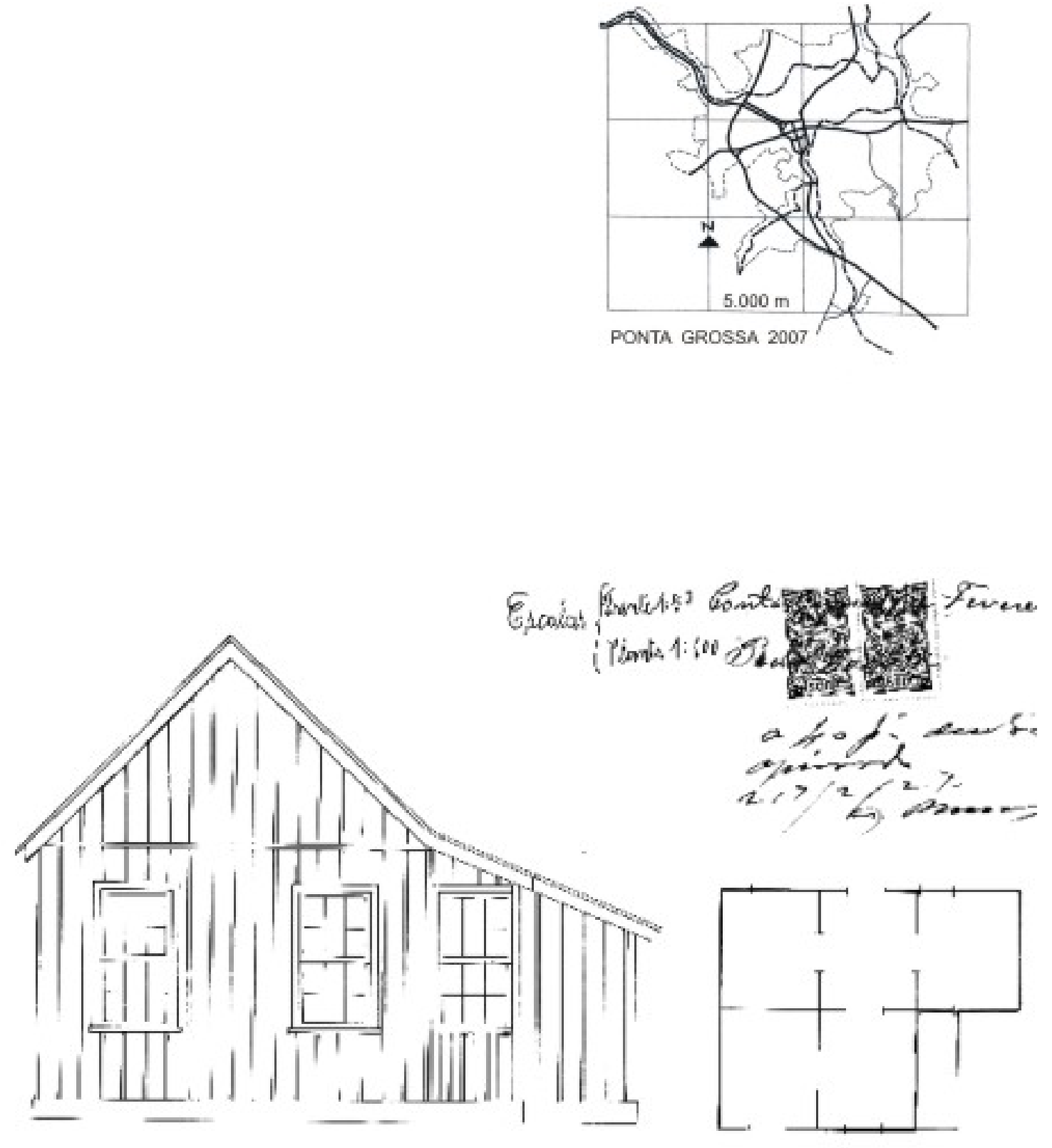

F033/27

Casa de madeira

Ano de construção - 1927

Prop. - Pedro Taran

Uso residencial

Fonte: prefeitura/2006 

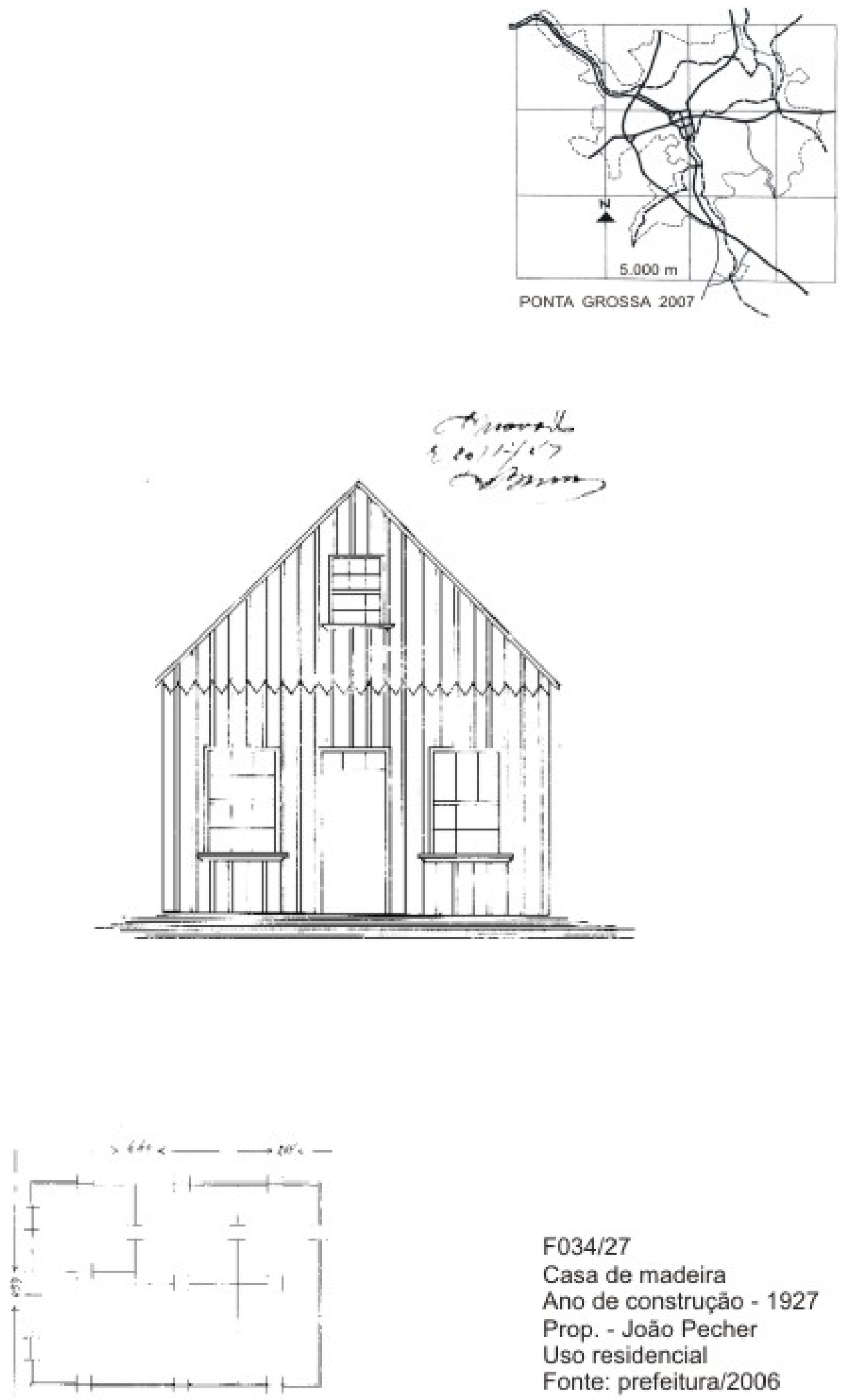

F034/27

Casa de madeira

Ano de construçăo - 1927

Prop. - João Pecher

Uso residencial

Fonte: prefeitura/2006 

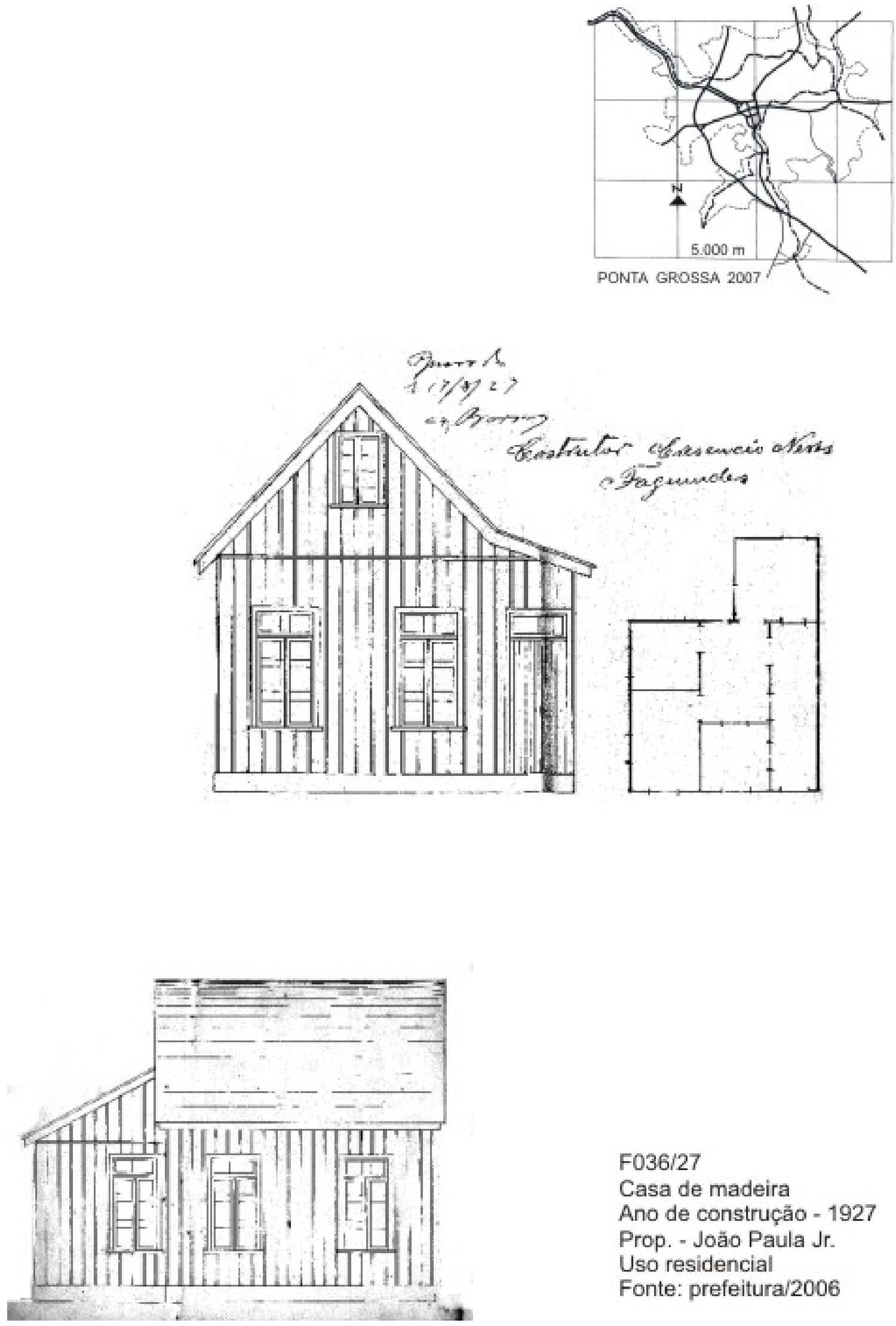

$\mathrm{F} 036 / 27$

Casa de madeira

Ano de construçăo - 1927

Prop. - João Paula Jr.

Uso residencial

Fonte: prefeitura/2006 

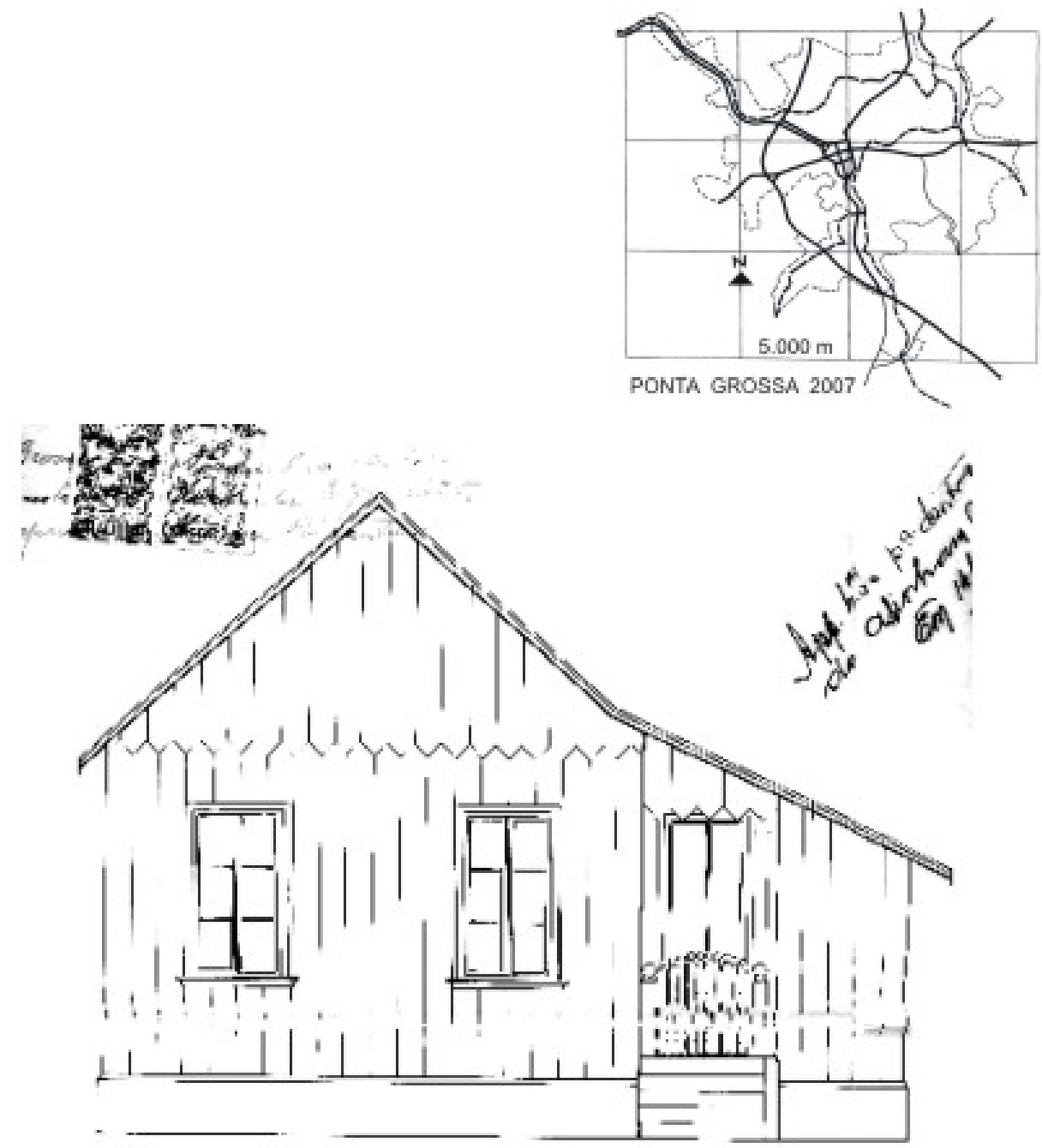

Gscale droe

Sisctia r.100

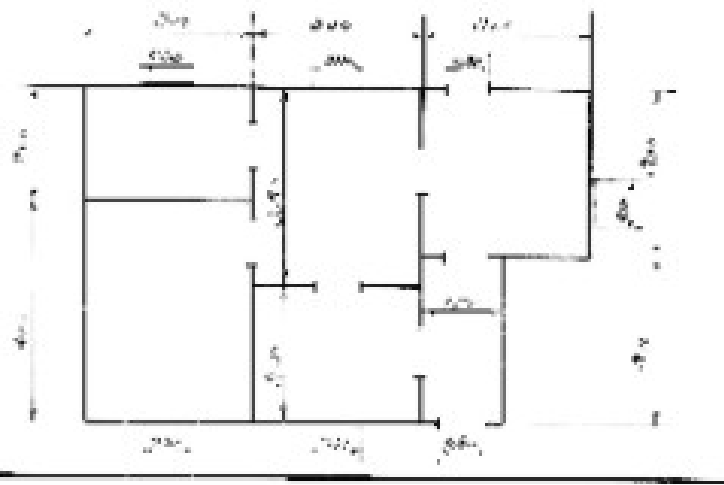

F037/27

Casa de madeira

Ano de construçăo - 1927

Prop. - Maria Ricetti

Uso residencial

Fonte: prefeitura/2006 

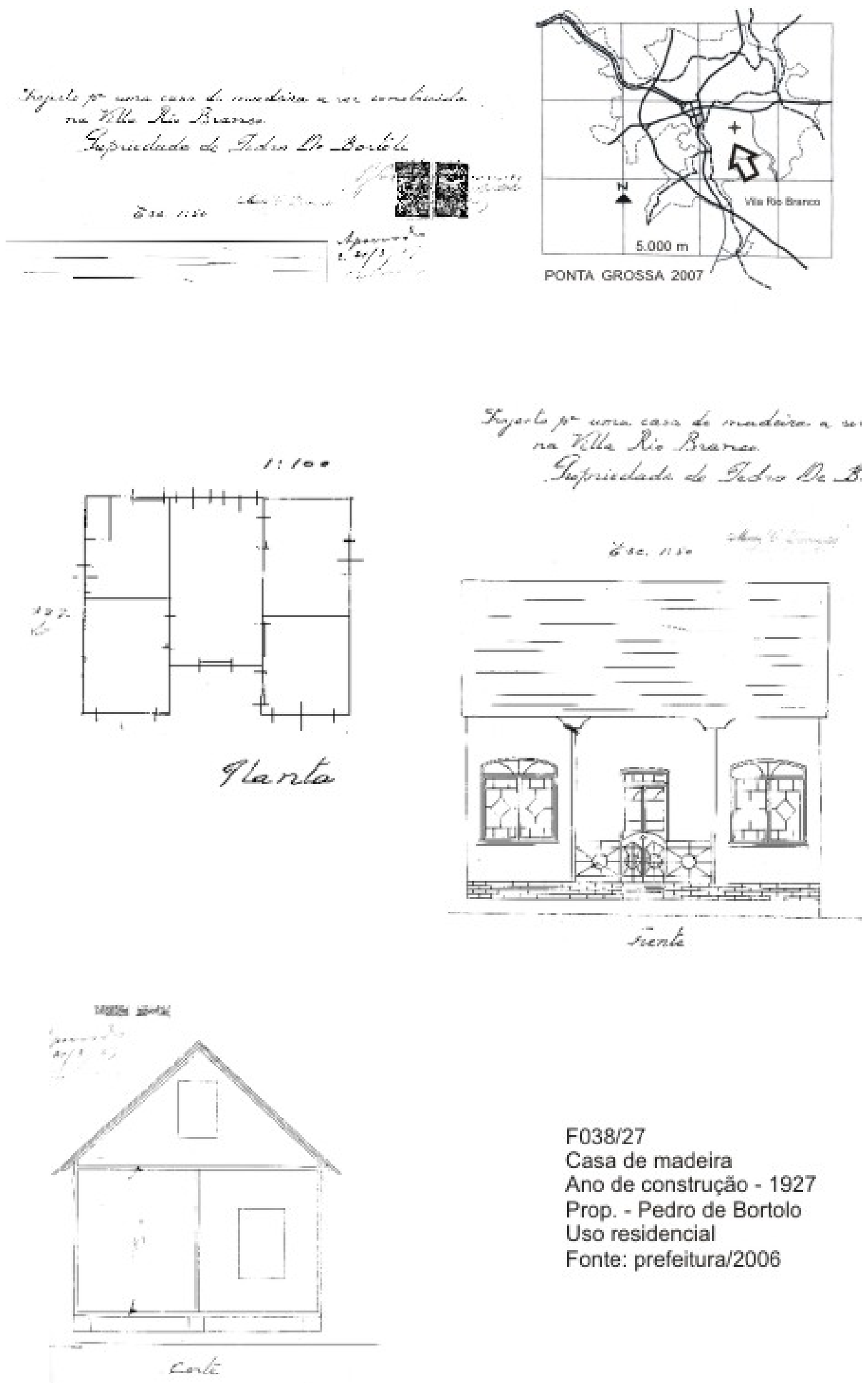

F038/27

Casa de madeira Ano de construçăo - 1927

Prop. - Pedro de Bortolo Uso residencial

Fonte: prefeitura/2006 
LEVANTAMENTO DE PROJETOS DE CASAS DE MADEIRA

APROVADOS NA PREFEITURA DE PONTA GROSSA NA DÉCADA DE 1930 

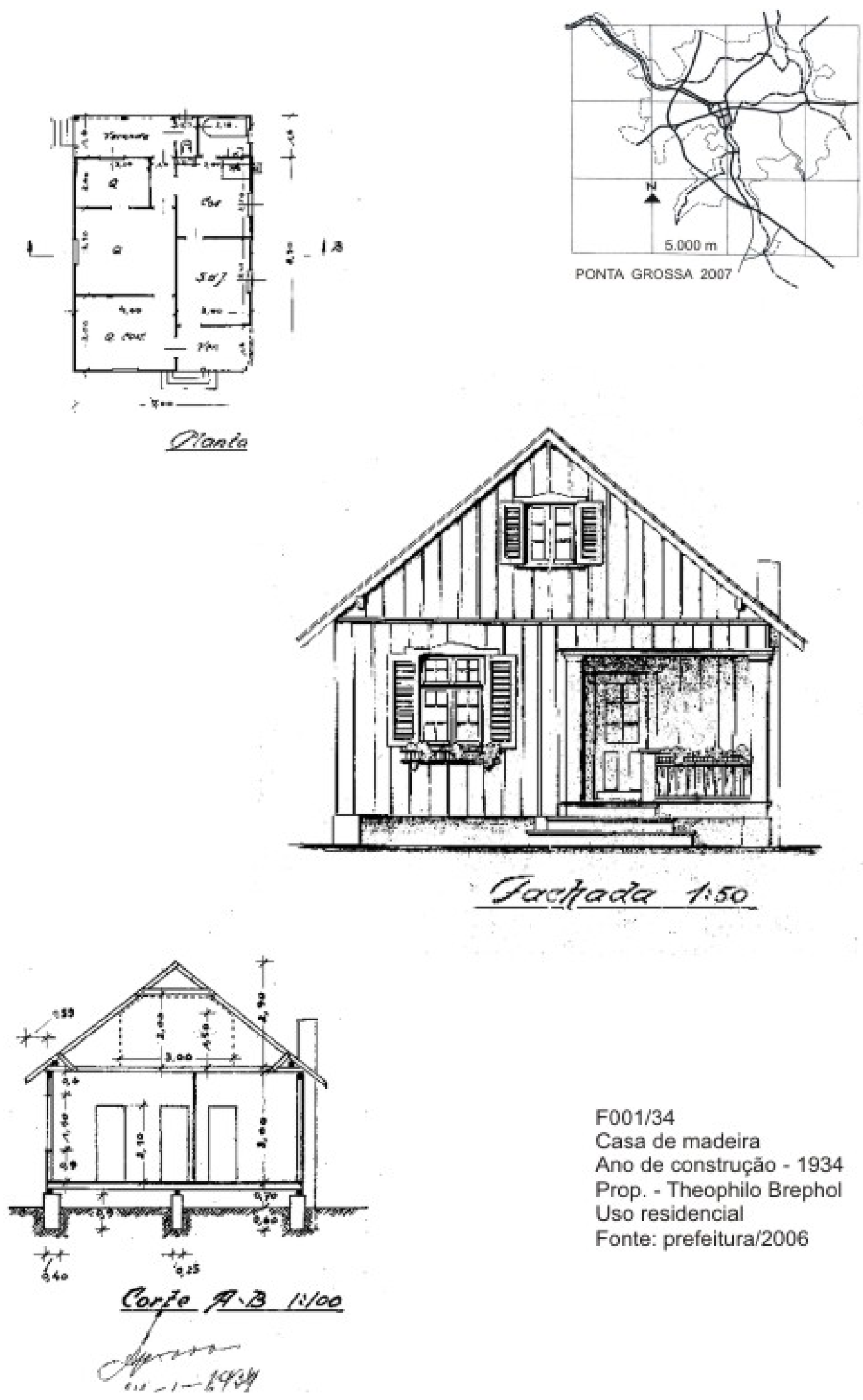

F001/34

Casa de madeira

Ano de construção - 1934

Prop. - Theophilo Brephol Uso residencial

Fonte: prefeitura/2006 

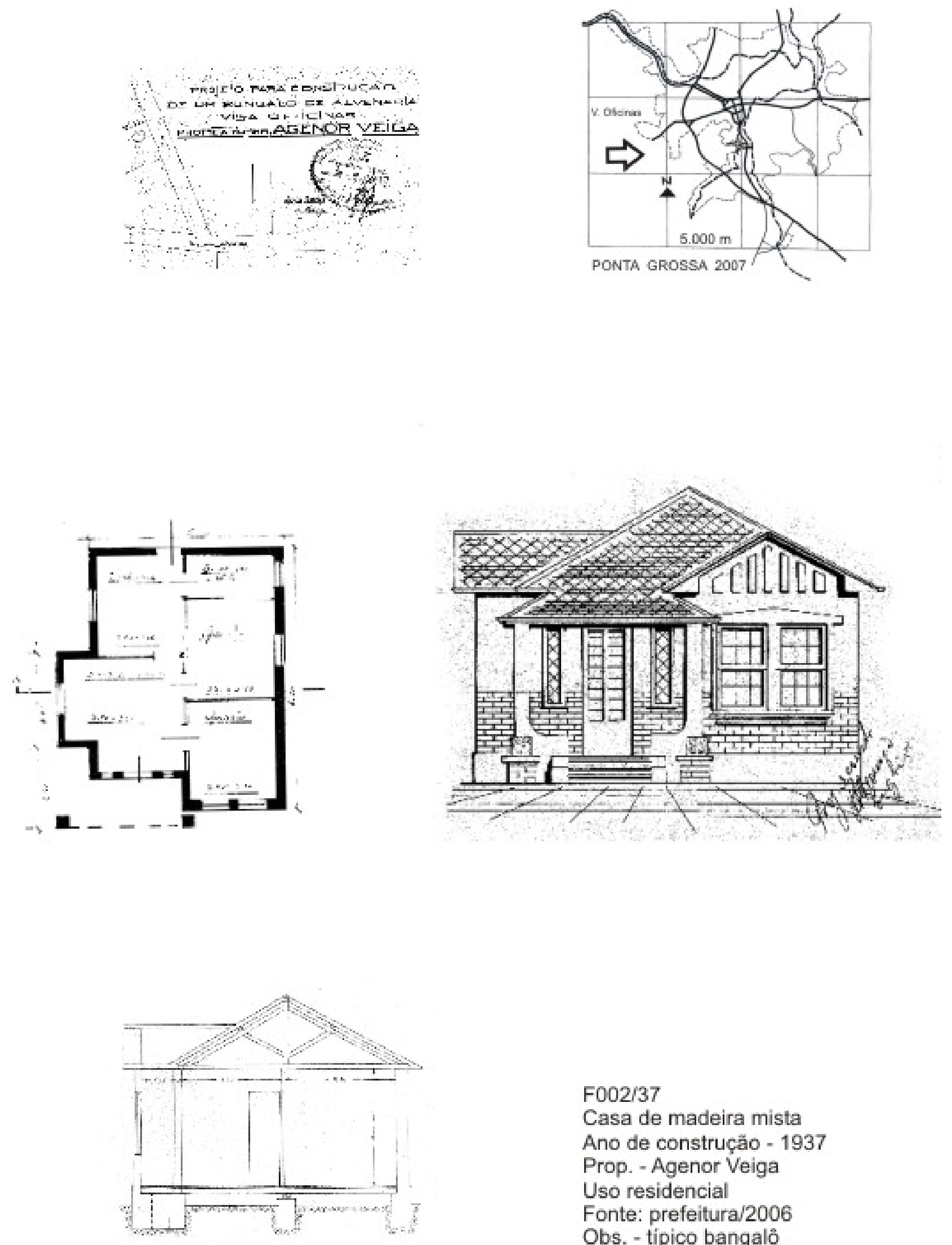

F002/37

Casa de madeira mista

Ano de construçăo - 1937

Prop. - Agenor Veiga

Uso residencial

Fonte: prefeitura/2006

Obs. - típico bangalô 

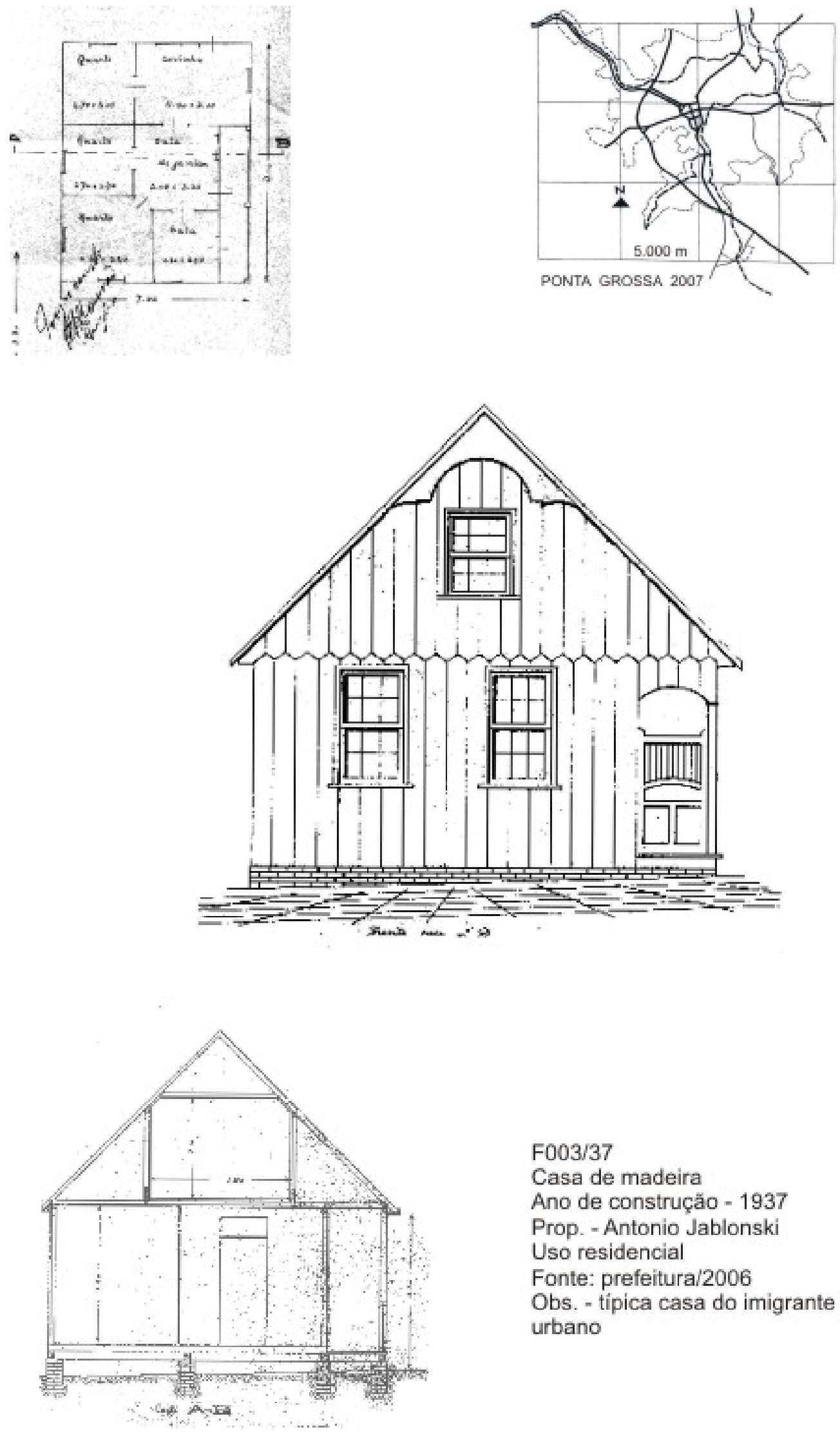

F003/37

Casa de madeira

Ano de construção - 1937

Prop. - Antonio Jablonski

Uso residencial

Fonte: prefeitura/2006

Obs. - típica casa do imigrante urbano 

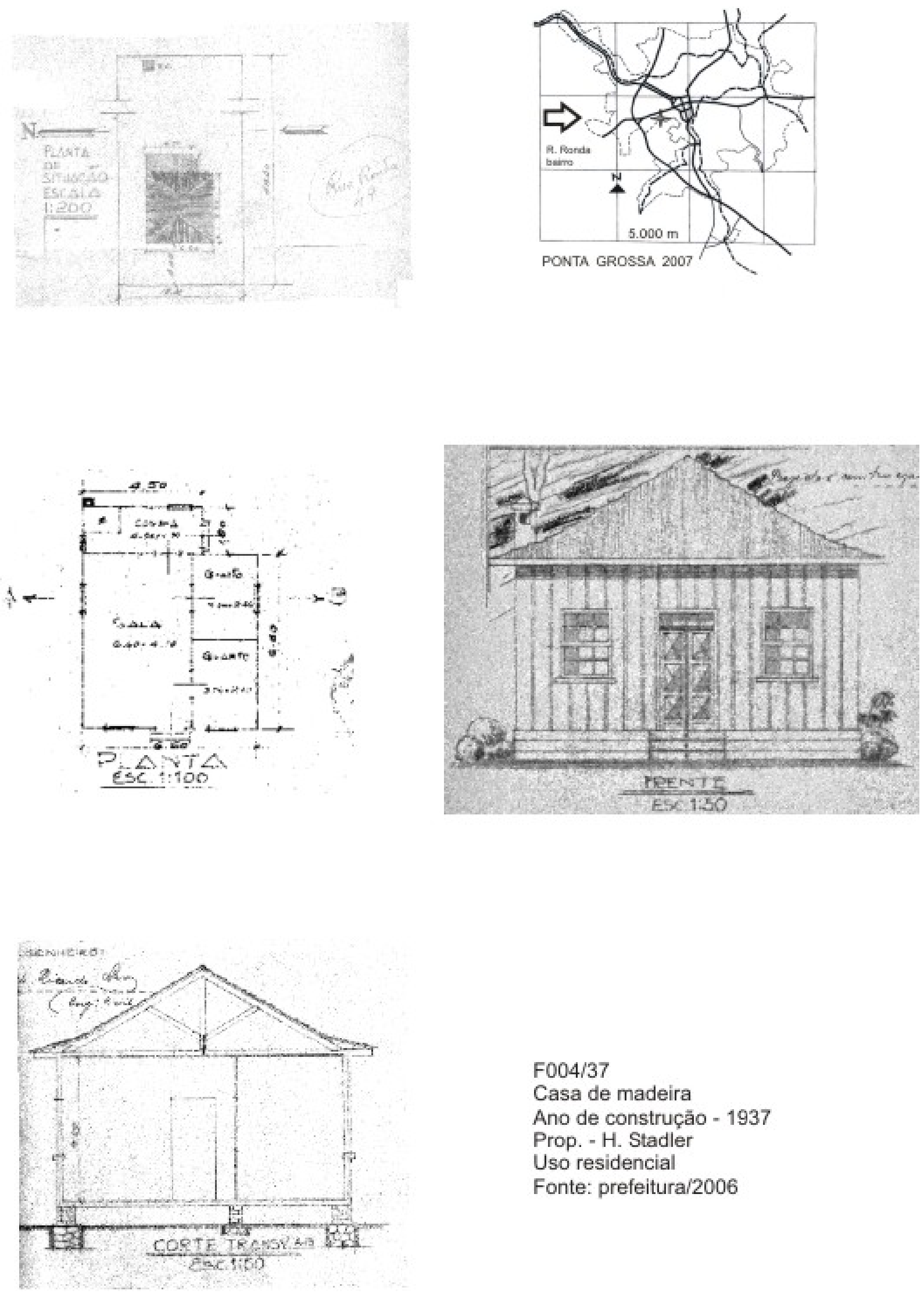

F004/37

Casa de madeira

Ano de construçăo - 1937

Prop. - H. Stadler

Uso residencial

Fonte: prefeitura/2006 

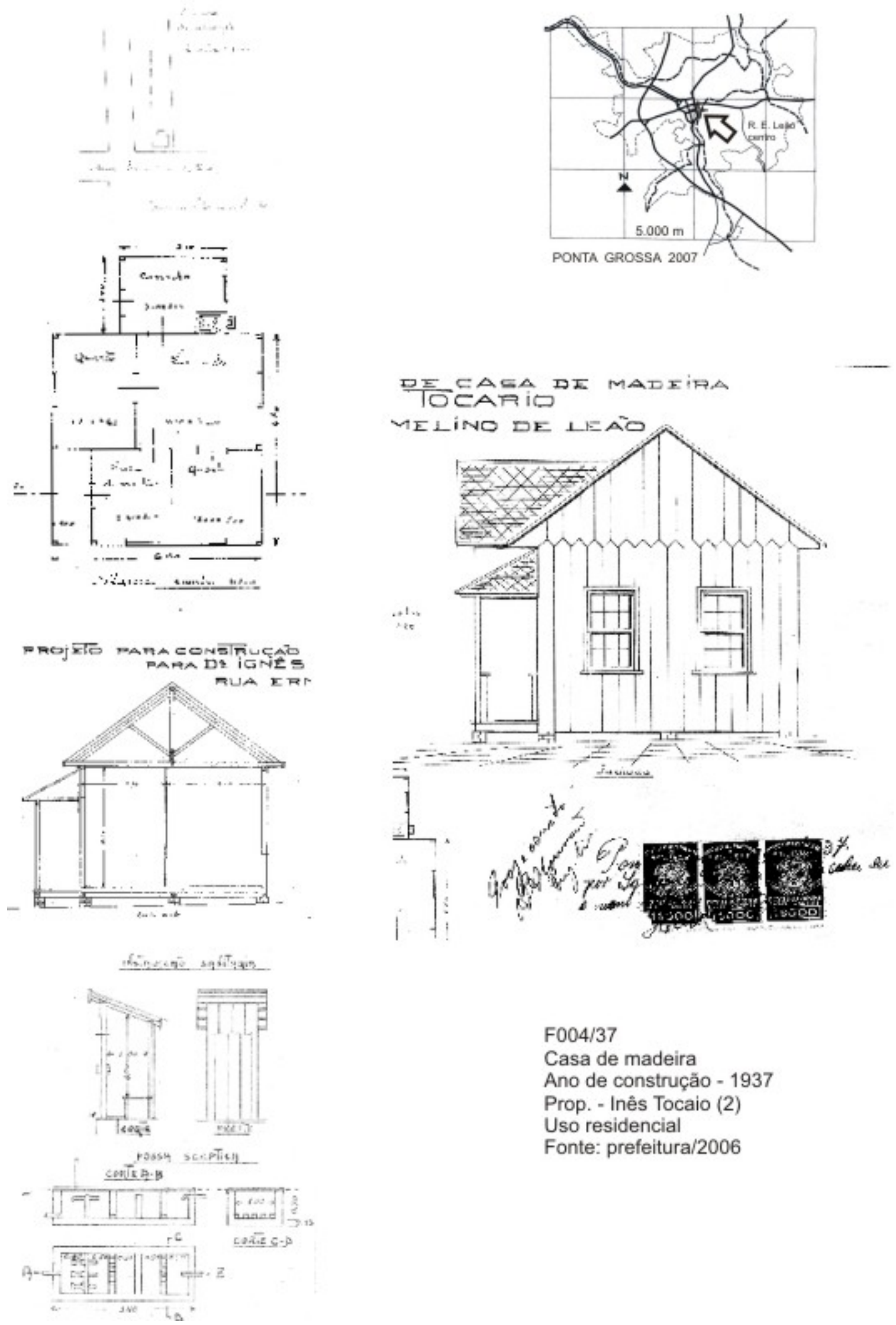

F004/37

Casa de madeira

Ano de construção - 1937

Prop. - Inês Tocaio (2)

Uso residencial

Fonte: prefeitura/2006 

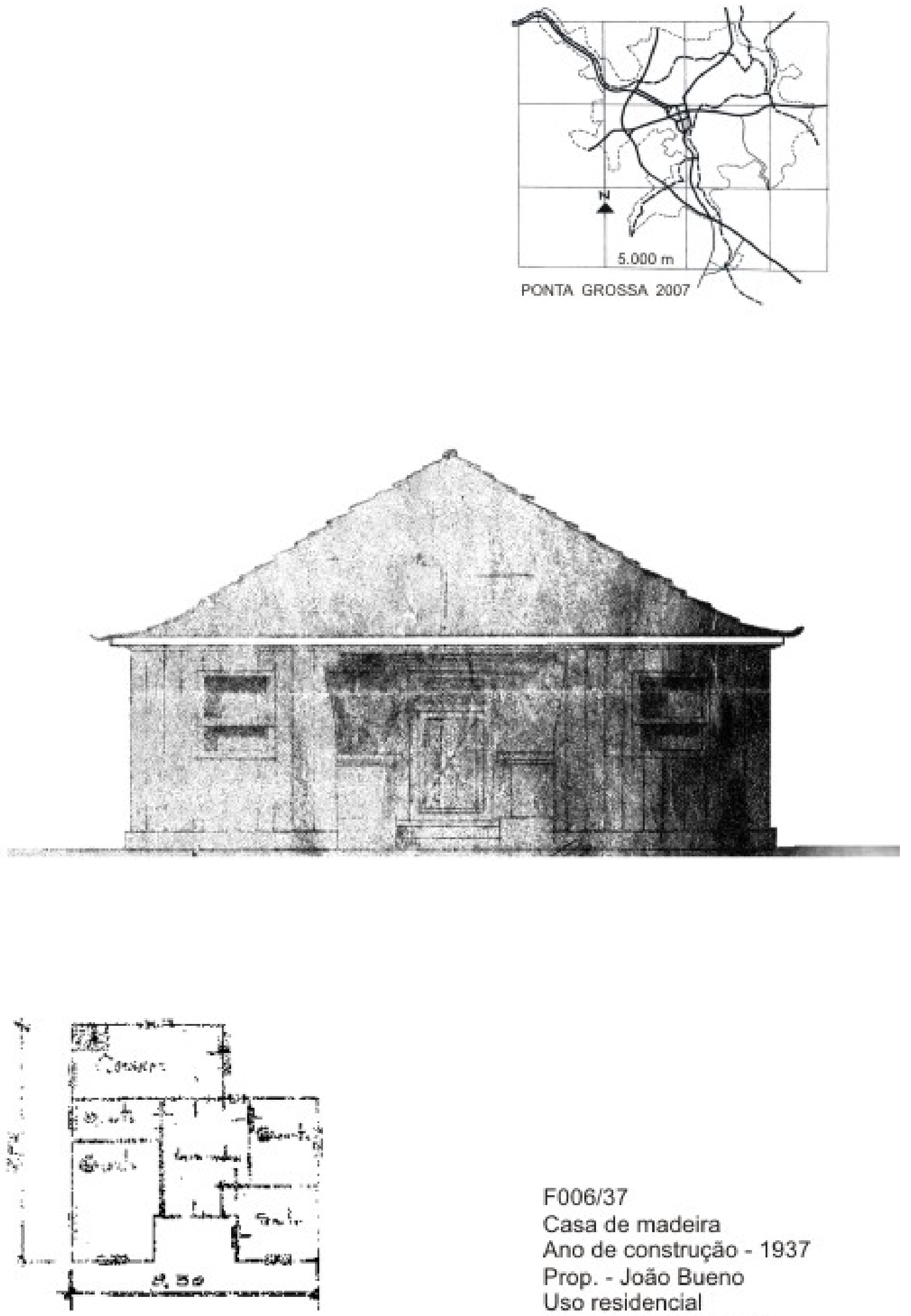

F006/37

Casa de madeira

Ano de construção - 1937

Prop. - Joäo Bueno

Uso residencial

Fonte: prefeitura/2006

Obs. 

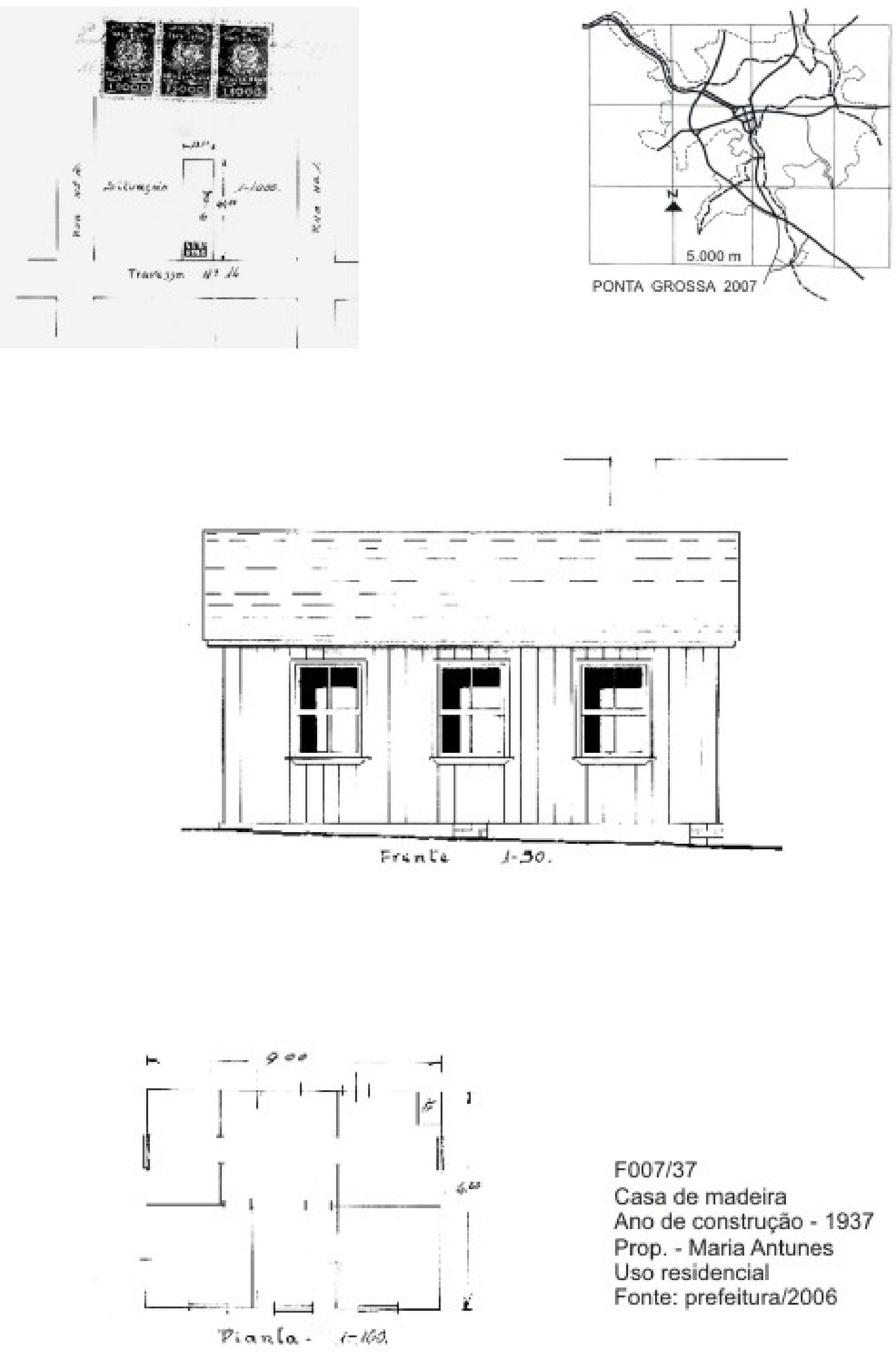

F007/37

Casa de madeira

Ano de construçăo - 1937

Prop. - Maria Antunes

Uso residencial

Fonte: prefeitura/2006 

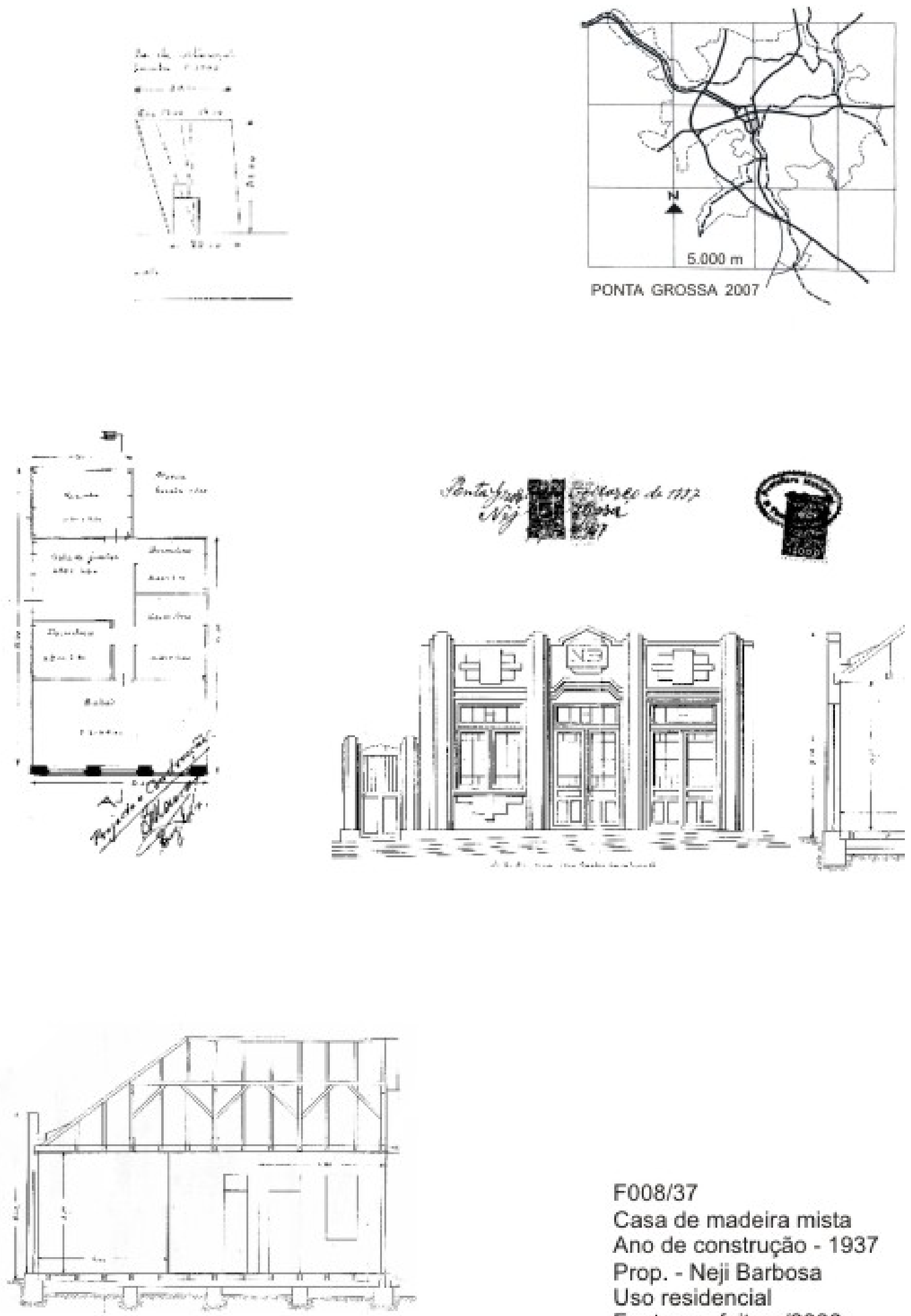

F008/37

Casa de madeira mista

Ano de construçäo - 1937

Prop. - Neji Barbosa

Uso residencial

Fonte: prefeitura/2006

Obs. - fachada eclética 

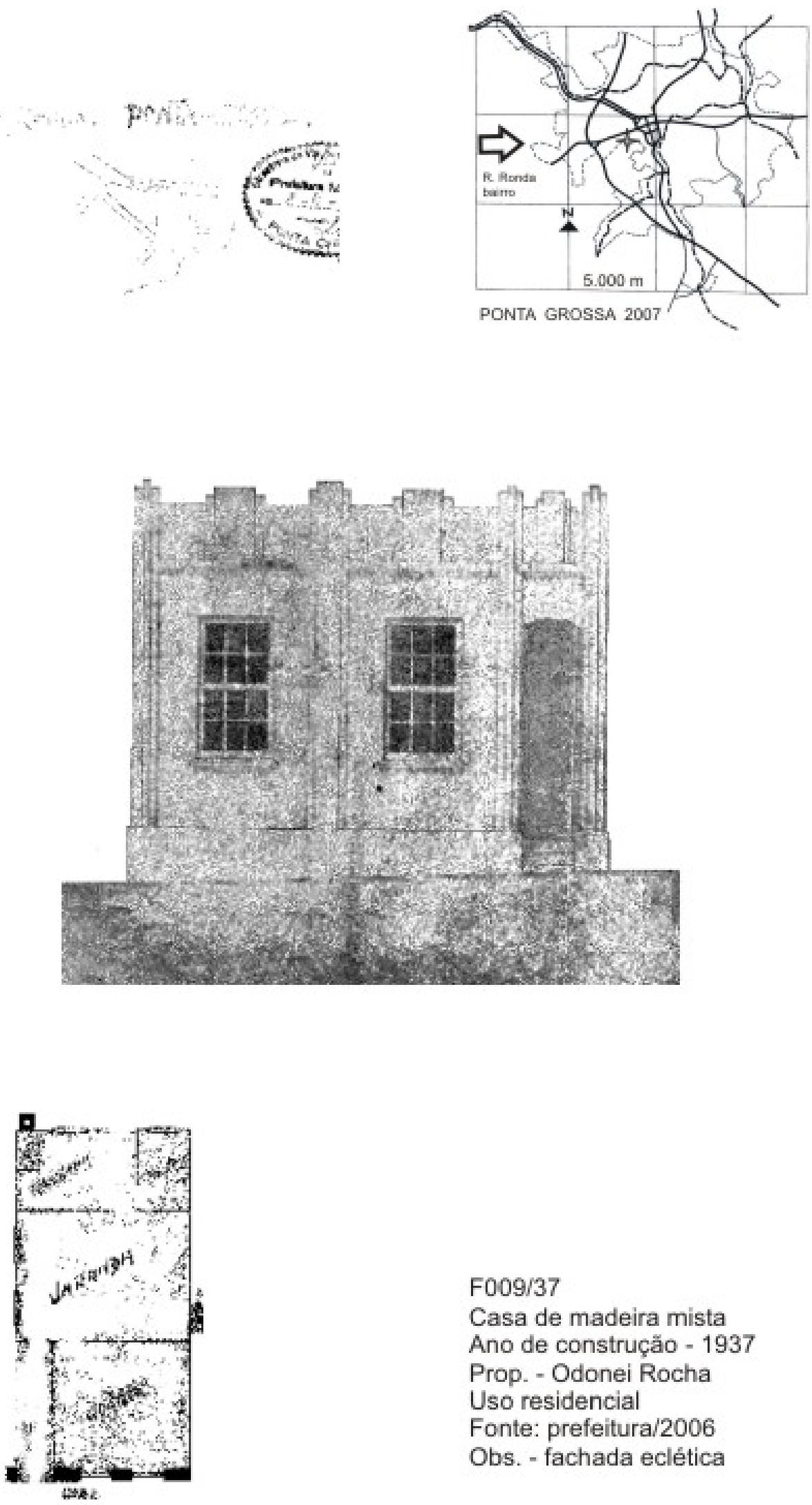

F009/37

Casa de madeira mista

Ano de construção - 1937

Prop. - Odonei Rocha

Uso residencial

Fonte: prefeitura/2006

Obs. - fachada eclética 


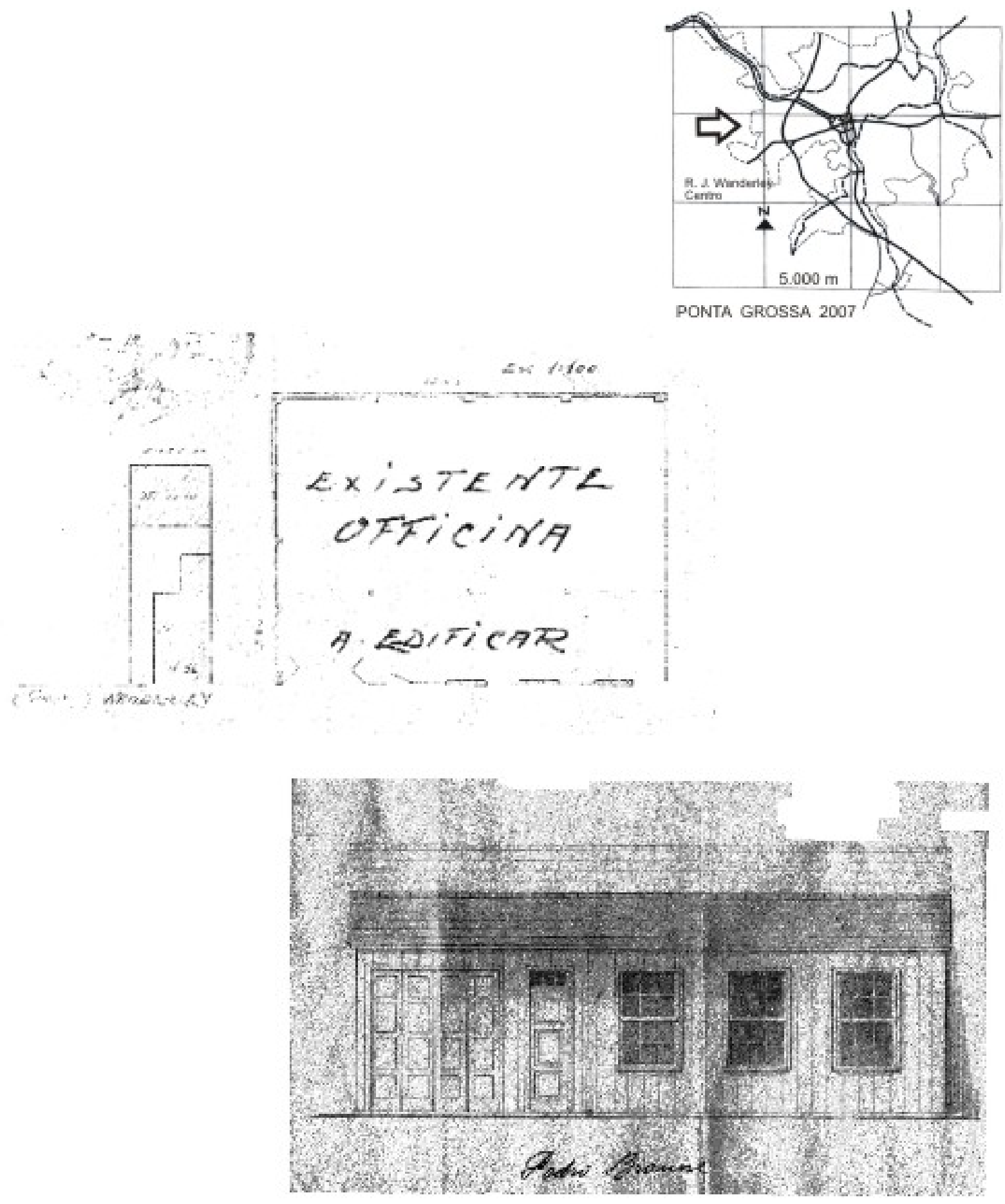

F010/37

Oficina em madeira

Ano de construçăo - 1937

Prop. - Pedro Braune

Uso comercial

Fonte: prefeitura/2006 


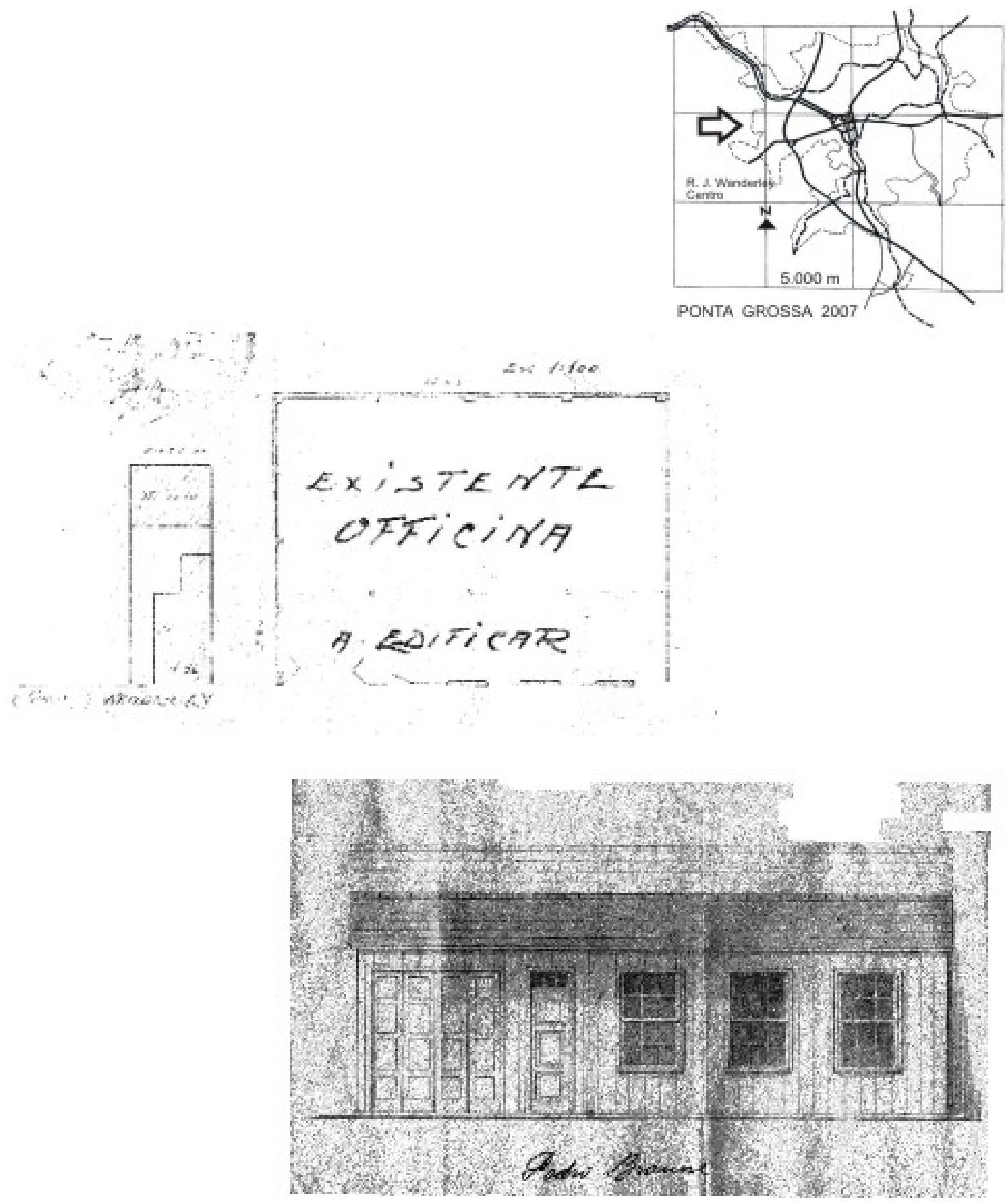

F010/37

Oficina em madeira

Ano de construçăo - 1937

Prop. - Pedro Braune

Uso comercial

Fonte: prefeitura/2006 

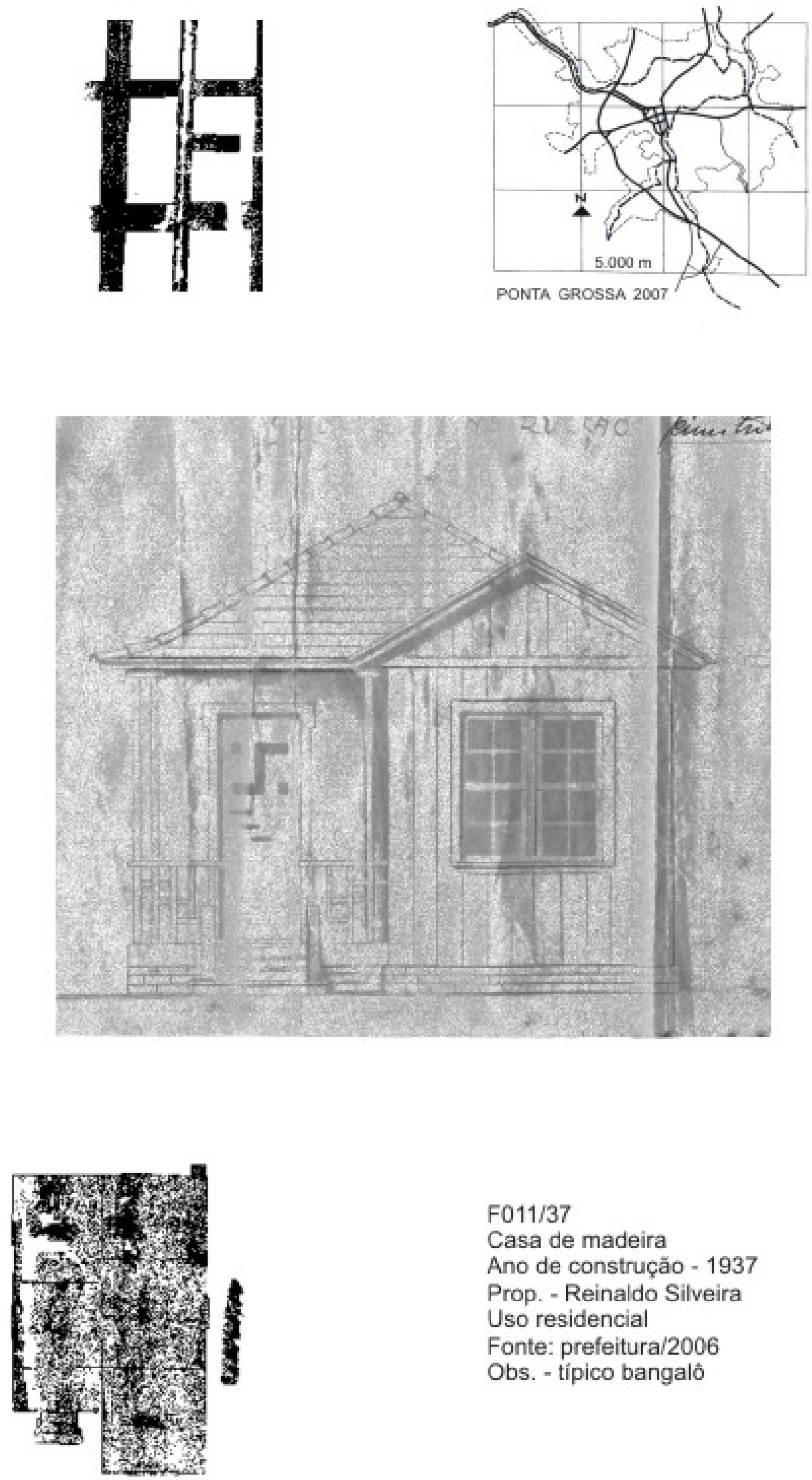

F011/37

Casa de madeira

Ano de construção - 1937

Prop. - Reinaldo Silveira

Uso residencial

Fonte: prefeitura/2006

Obs. - típico bangalôt 


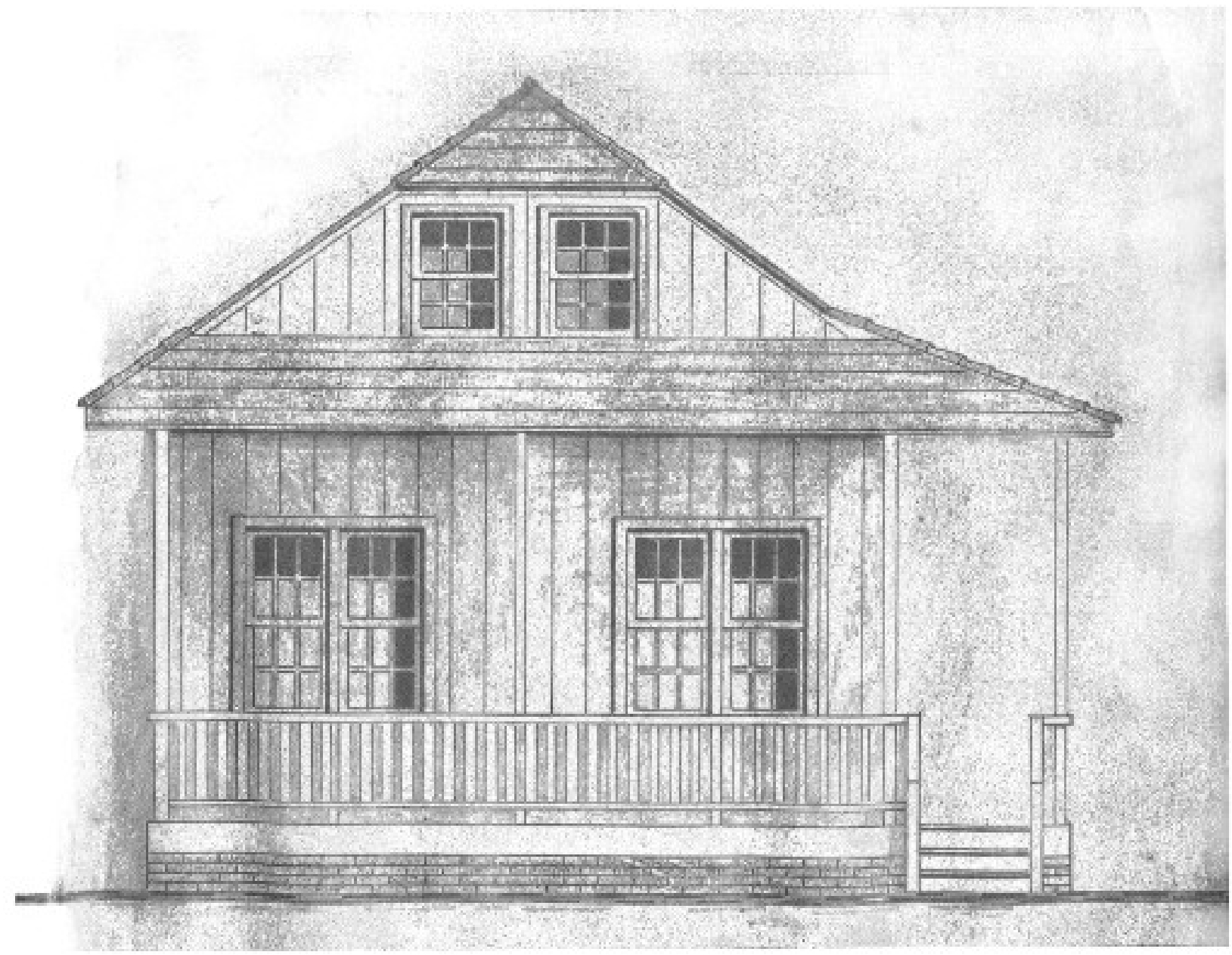

F012/37 - parte A

Casa de madeira

Ano de construção - 1937

Prop. - Ricardo Jeny

Uso residencial

Fonte: prefeitura/2006

Obs. - típica casa do imigrante urbano 


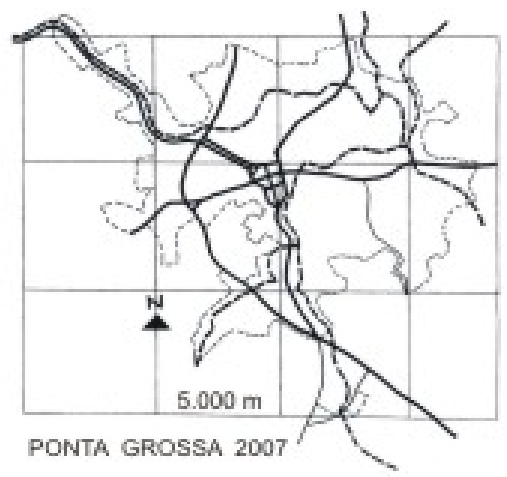

femene ripe
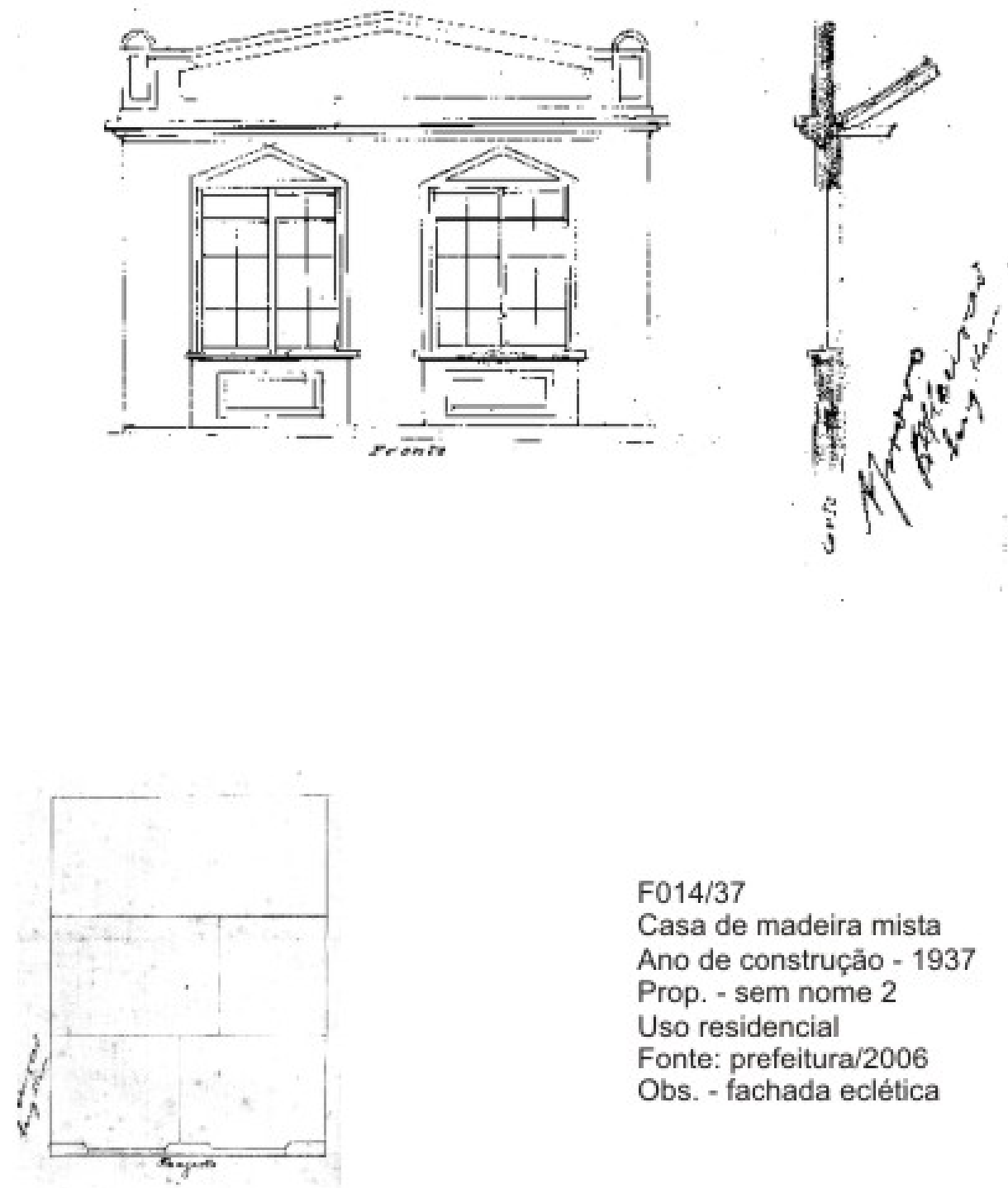

F014/37

Casa de madeira mista

Ano de construçăo - 1937

Prop. - sem nome 2

Uso residencial

Fonte: prefeitura/2006

Obs. - fachada eclética 

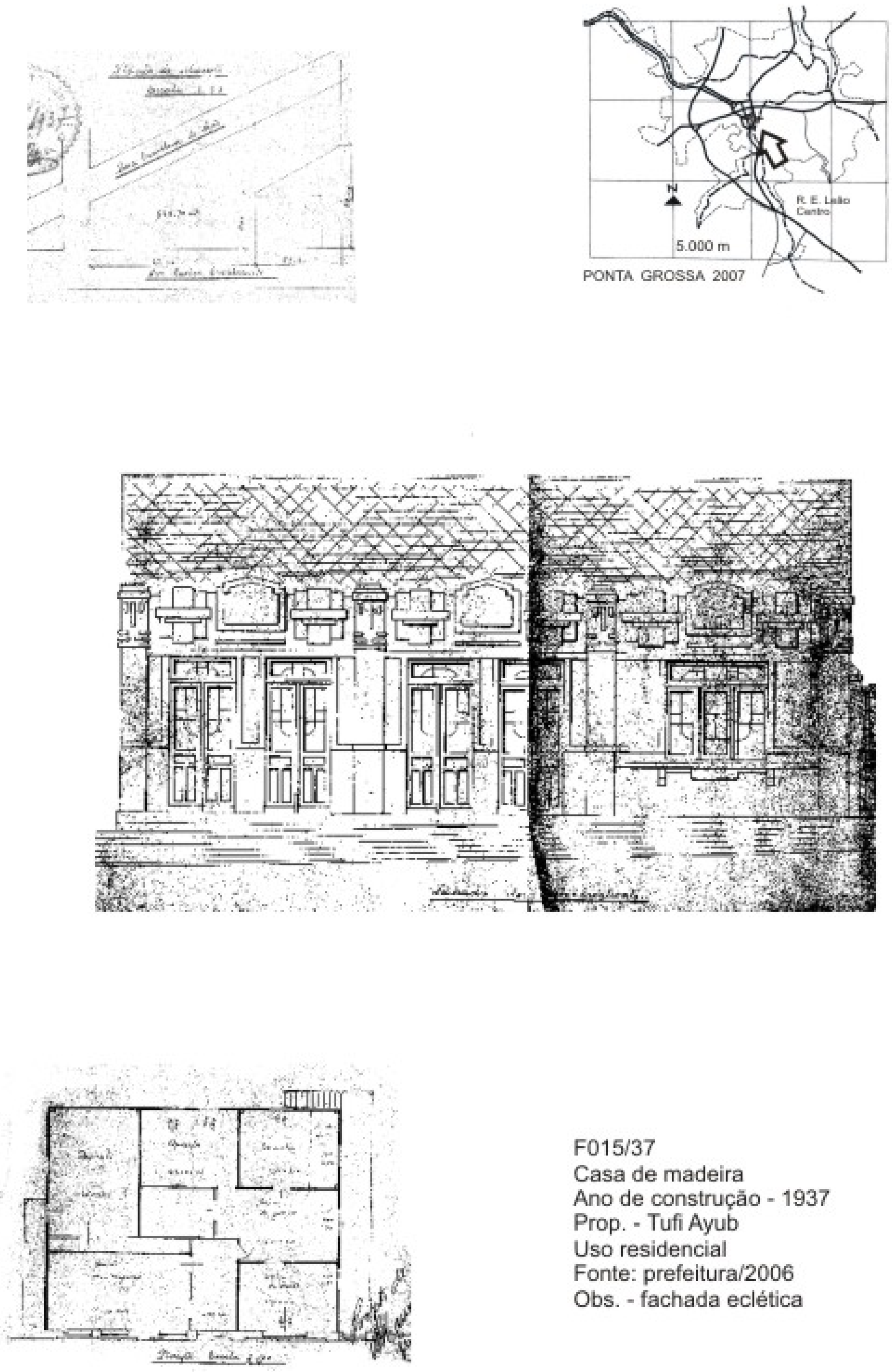

F015/37

Casa de madeira

Ano de construção - 1937

Prop. - Tufi Ayub

Uso residencial

Fonte: prefeitura/2006

Obs. - fachada eclética 


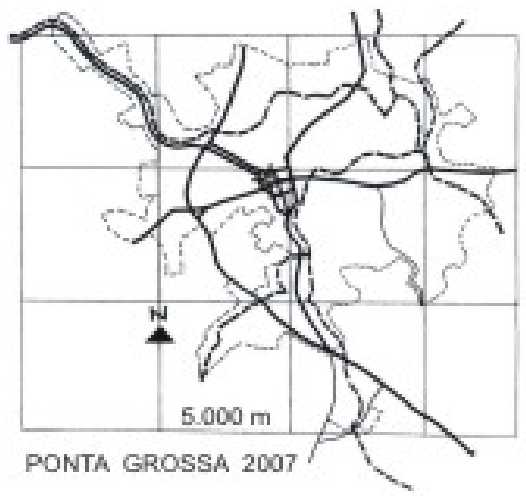

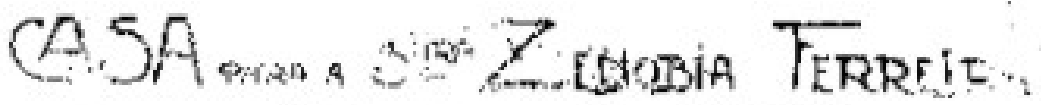

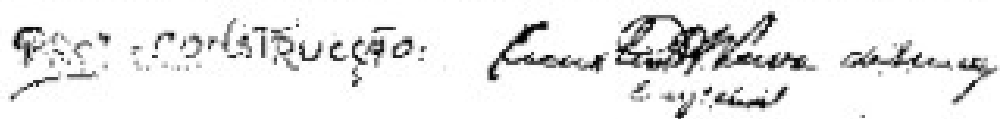
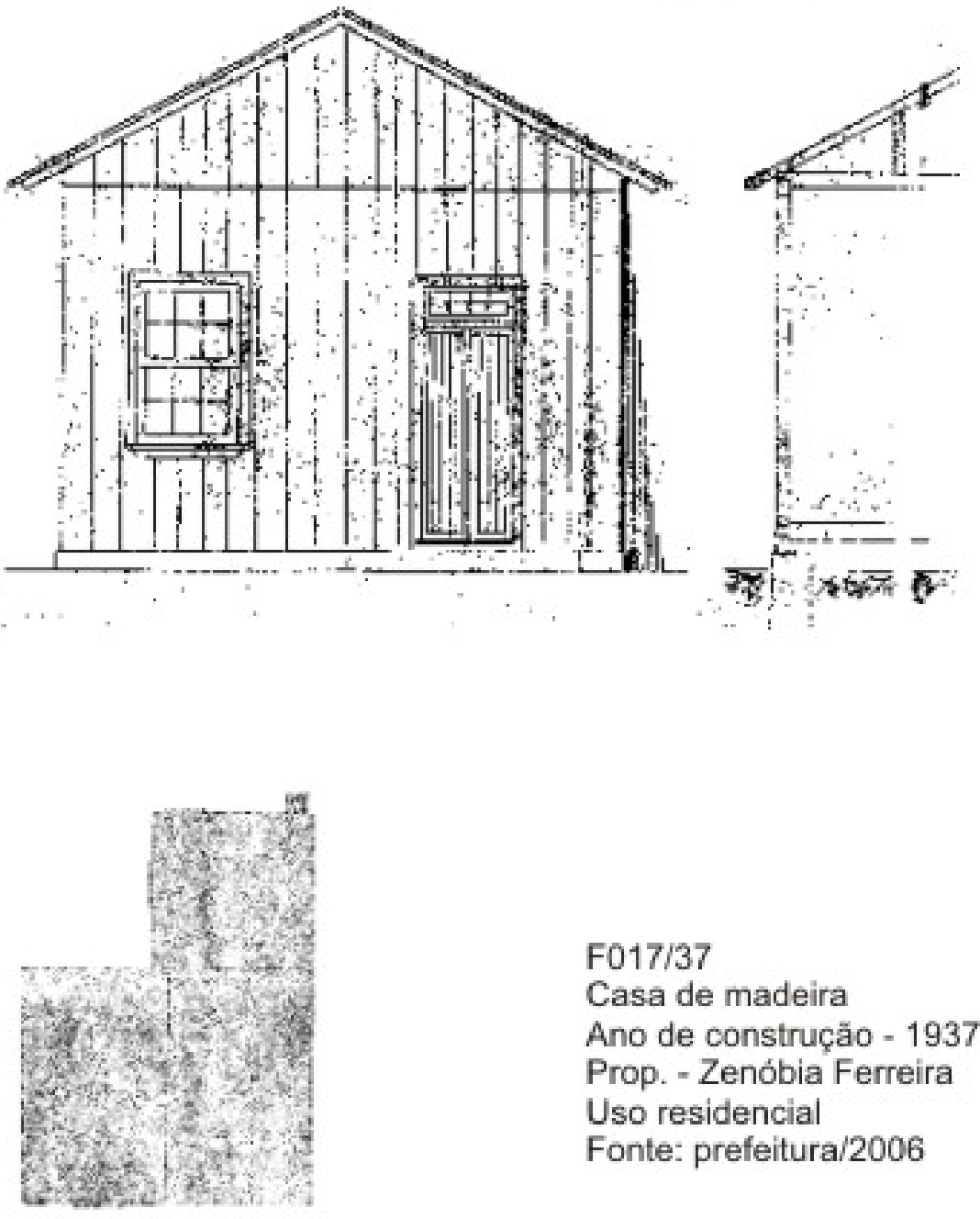

F017/37

Casa de madeira

Ano de construçăo - 1937

Prop. - Zenóbia Ferreira

Uso residencial

Fonte: prefeitura/2006 

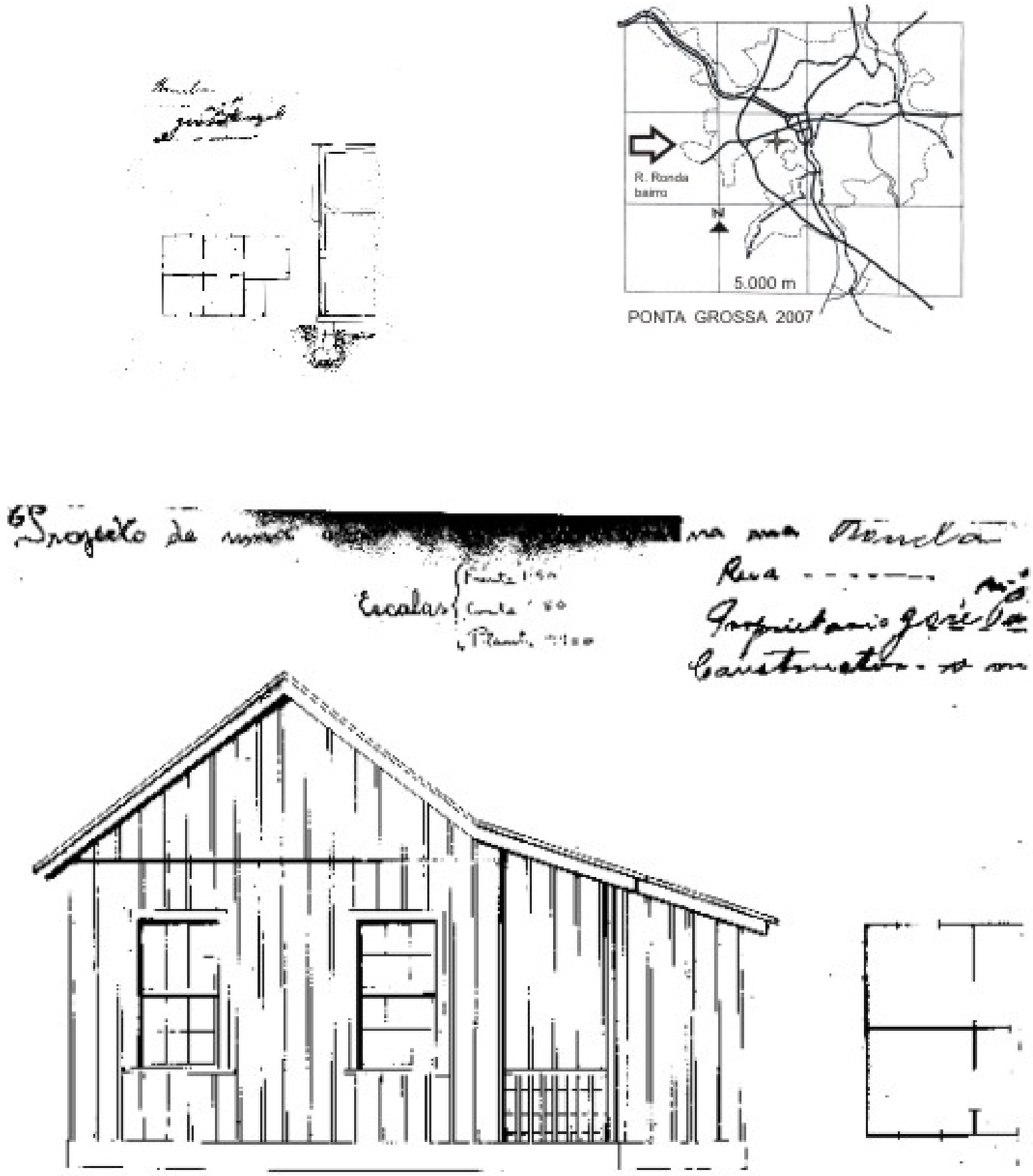

F017/38

Casa de madeira

Ano de construção - 1938

Proprietário - José Pastivazak

Uso residencial

Fonte: prefeitura/2006 

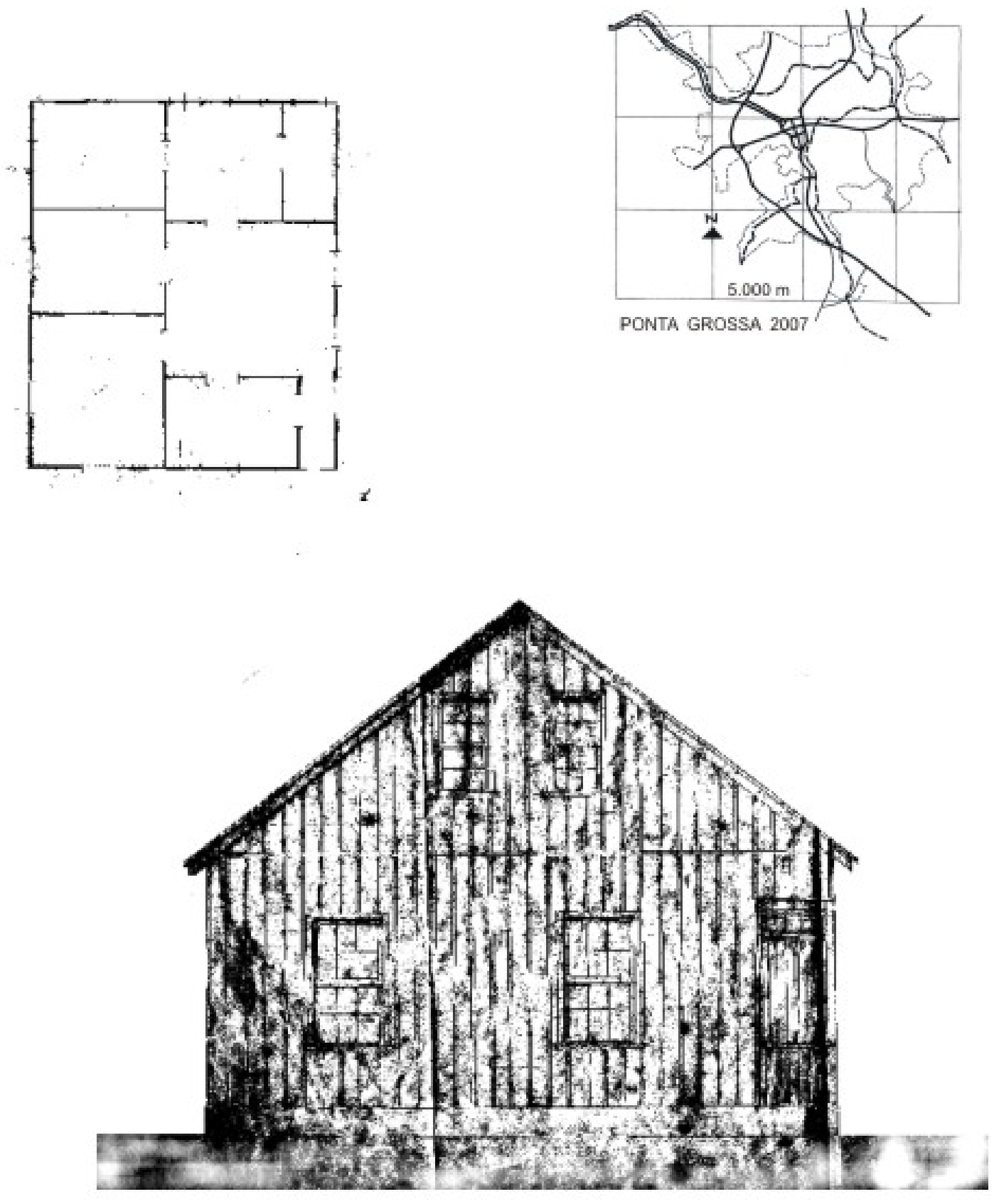

F018/38

Casa de madeira

Ano de construção - 1938

Prop. - Leão Federmann

Uso residencial

Fonte: prefeitura/2006

Obs. - típica planta longitudinal com sótäo e varanda - ocorre em toda a cidade 

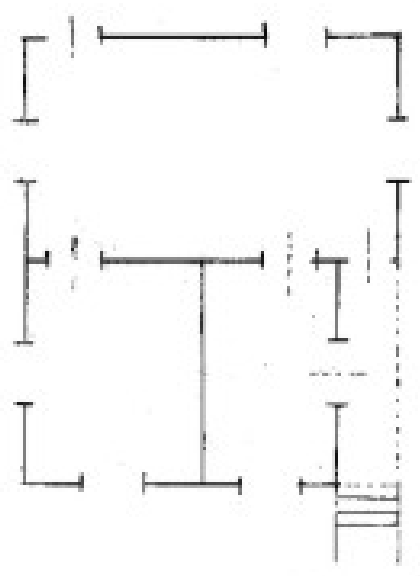

2hete de lade
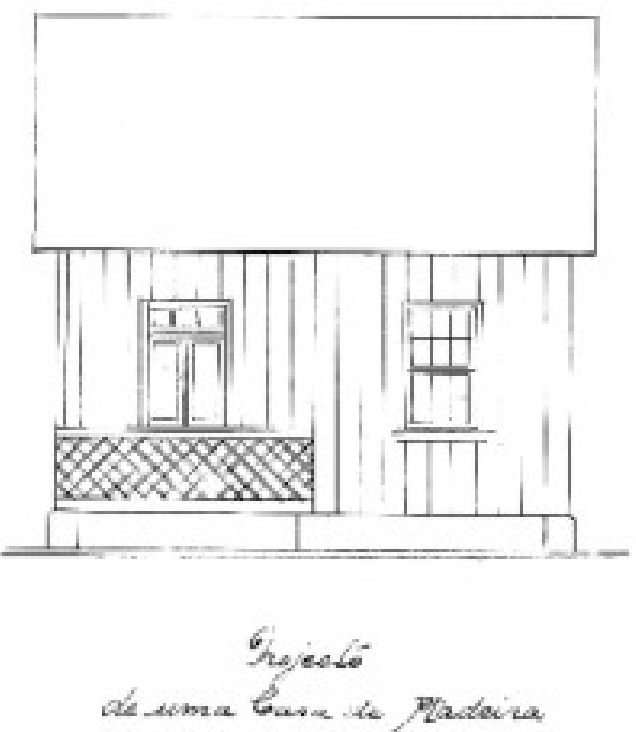

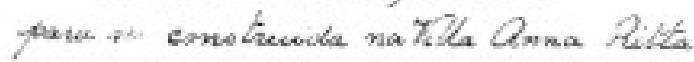

puobe de Thavat Thasmbien
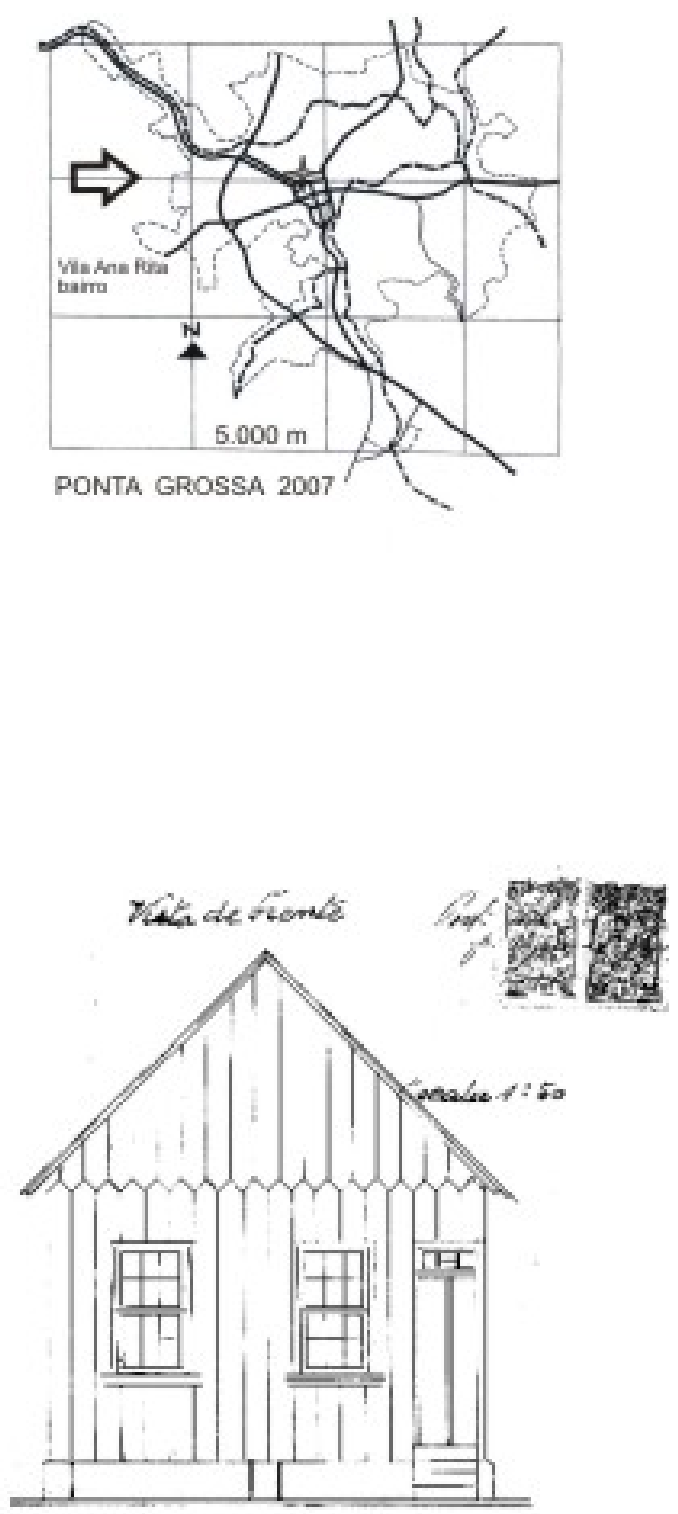

F019/39

Casa de madeira

Ano de construção - 1939

Prop. - Manoel Wambier

Uso residencial

Fonte: prefeitura/2006 
LEVANTAMENTO DE PROJETOS DE CASAS DE MADEIRA APROVADOS NA PREFEITURA DE PONTA GROSSA NA DÉCADA DE 1940 

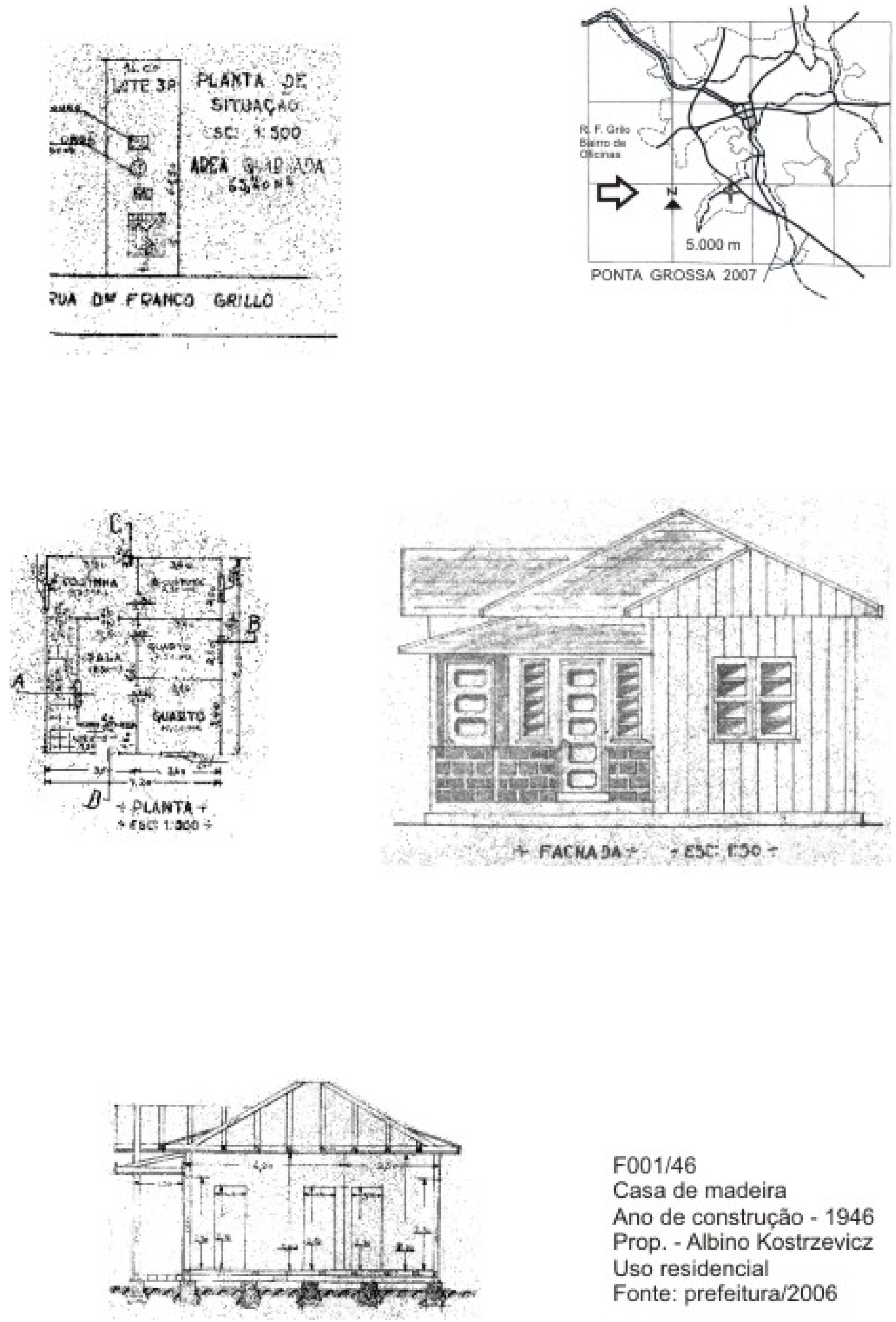

F001/46

Casa de madeira

Ano de construçăo - 1946 Prop. - Albino Kostrzevicz Uso residencial

Fonte: prefeitura/2006 

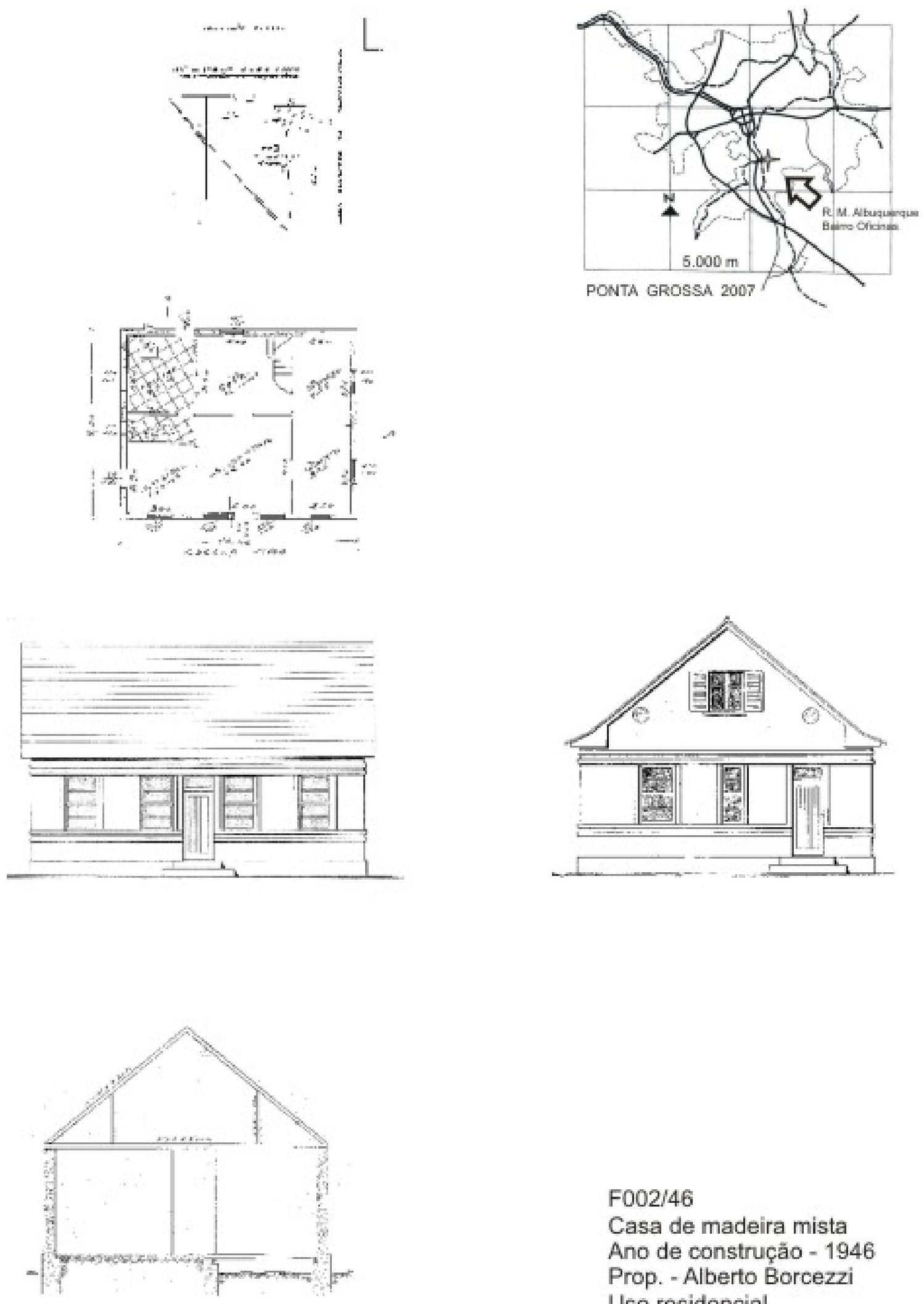

F002/46

Casa de madeira mista

Ano de construção - 1946

Prop. - Alberto Borcezzi

Uso residencial

Fonte: prefeitura/2006

Obs.- Típico chalé com sótāo 

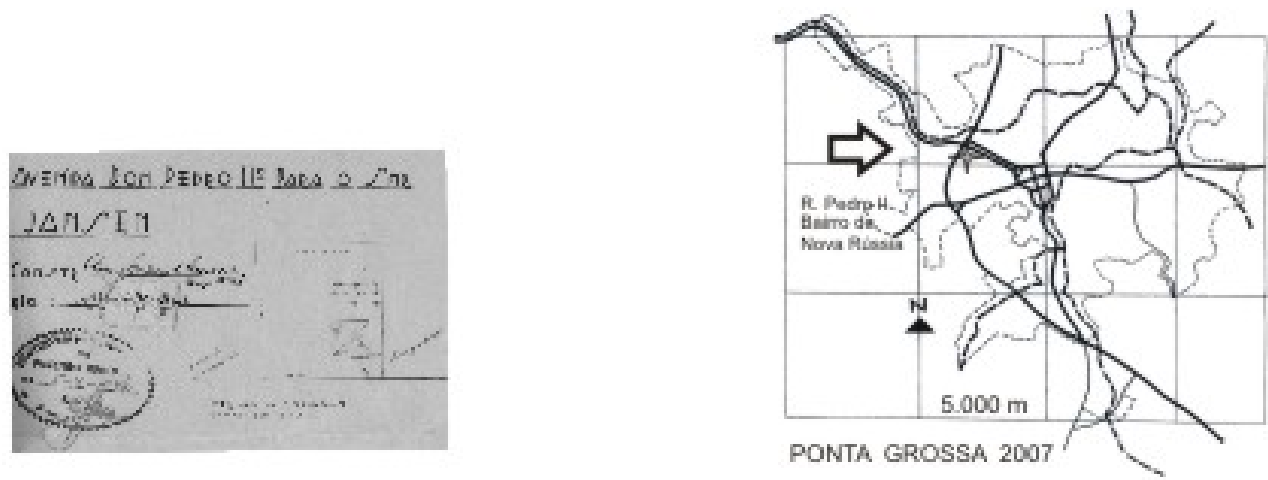

PONTA GROSSA 2007
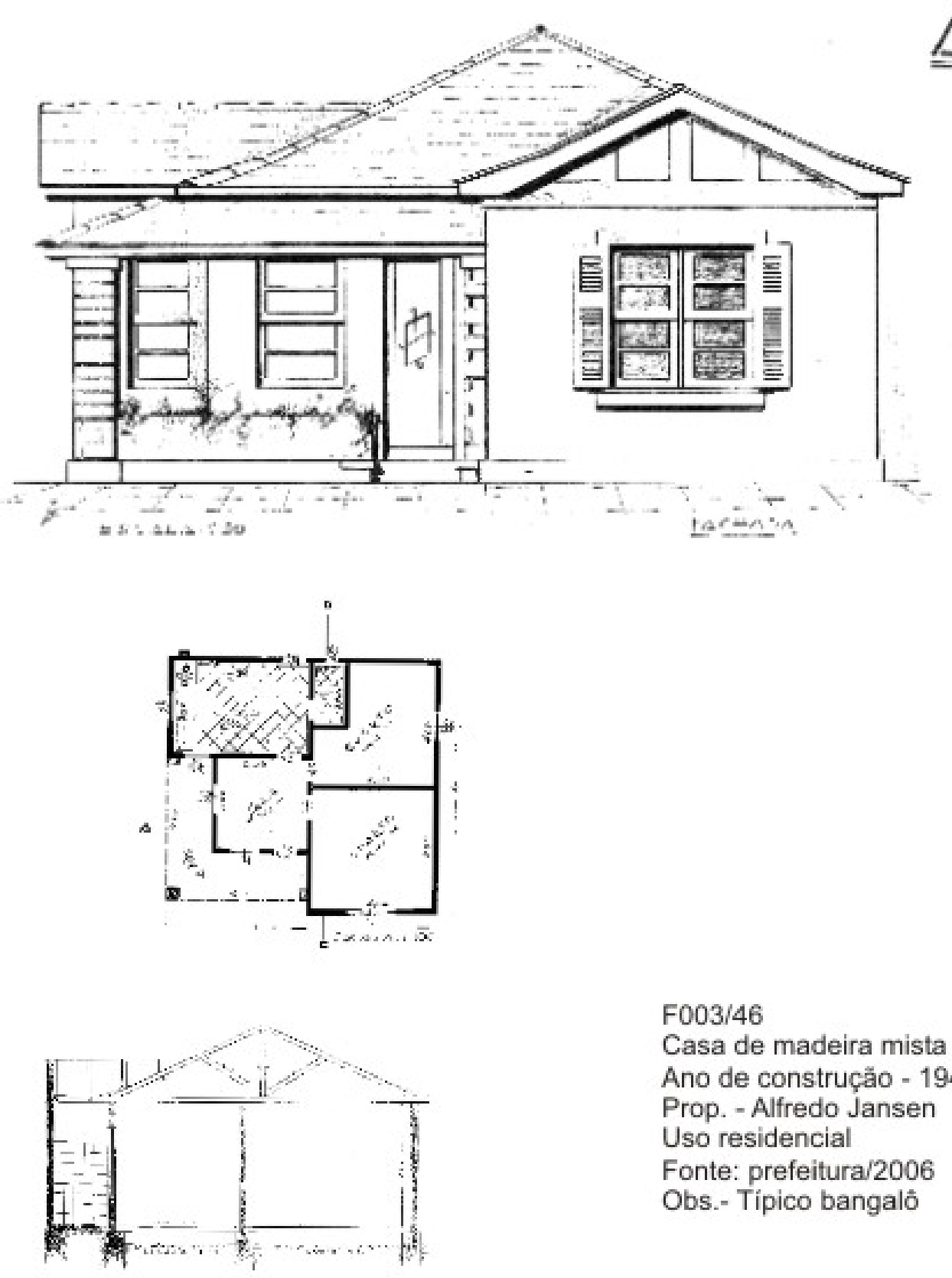

F003/46

Casa de madeira mista

Ano de construção - 1946

Prop. - Alfredo Jansen

Uso residencial

Fonte: prefeitura/2006

Obs.- Típico bangalô 
Reojeto be una cara
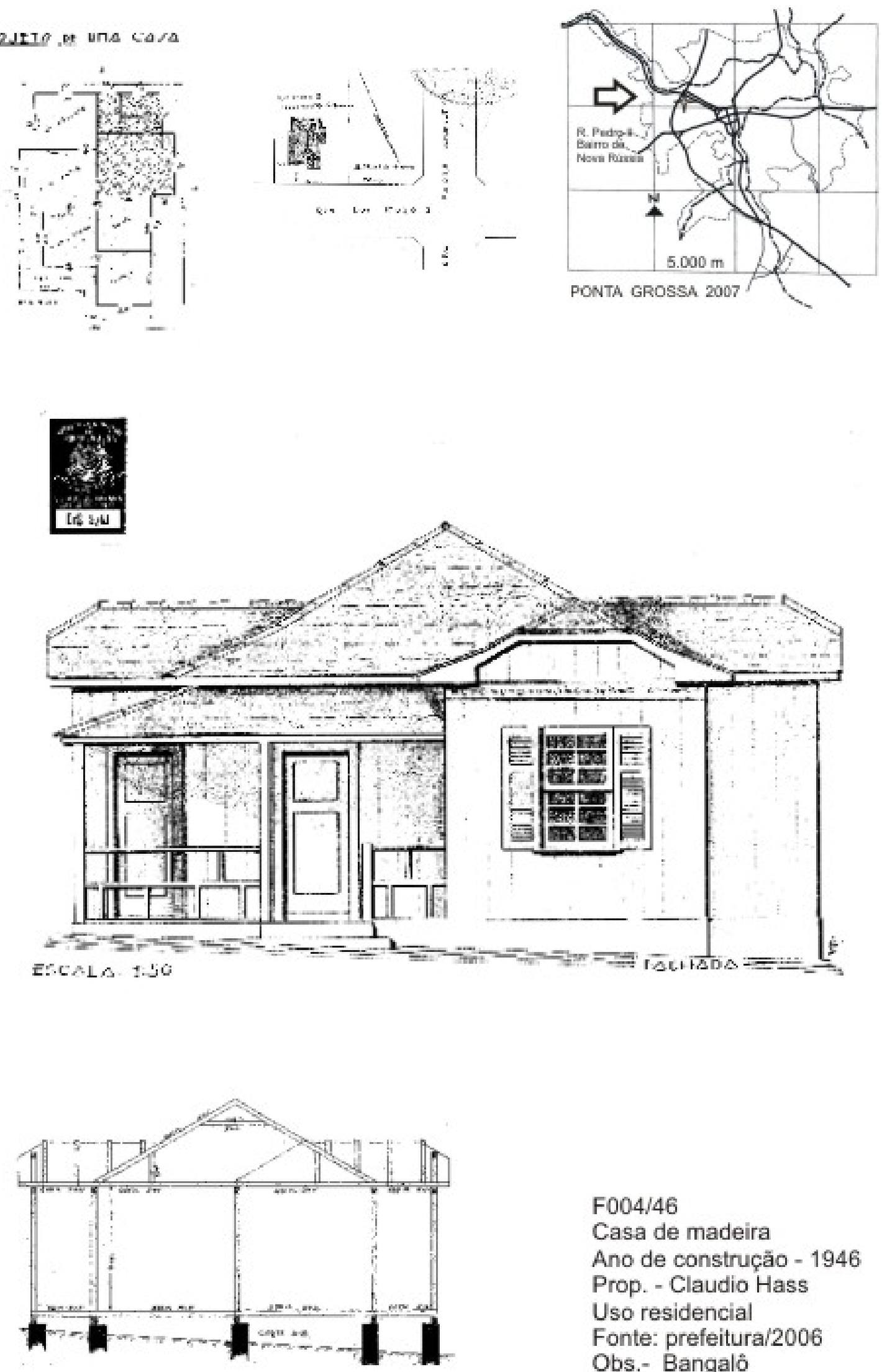

F004/46

Casa de madeira

Ano de construção - 1946

Prop. - Claudio Hass

Uso residencial

Fonte: prefeitura/2006

Obs.- Bangalô 

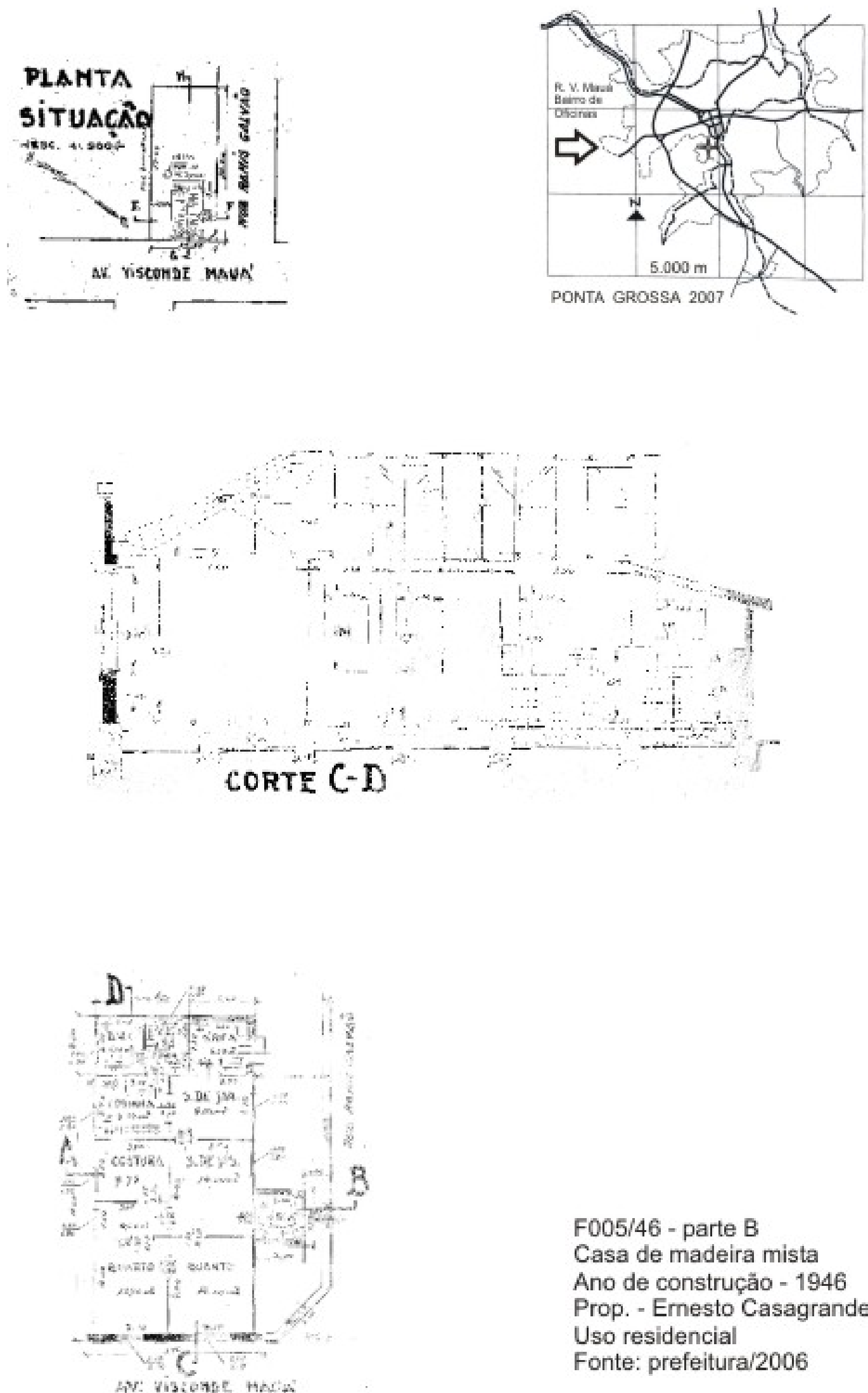

F005/46 - parte B

Casa de madeira mista

Ano de construçăo - 1946

Prop. - Emesto Casagrande Uso residencial

Fonte: prefeitura/2006 

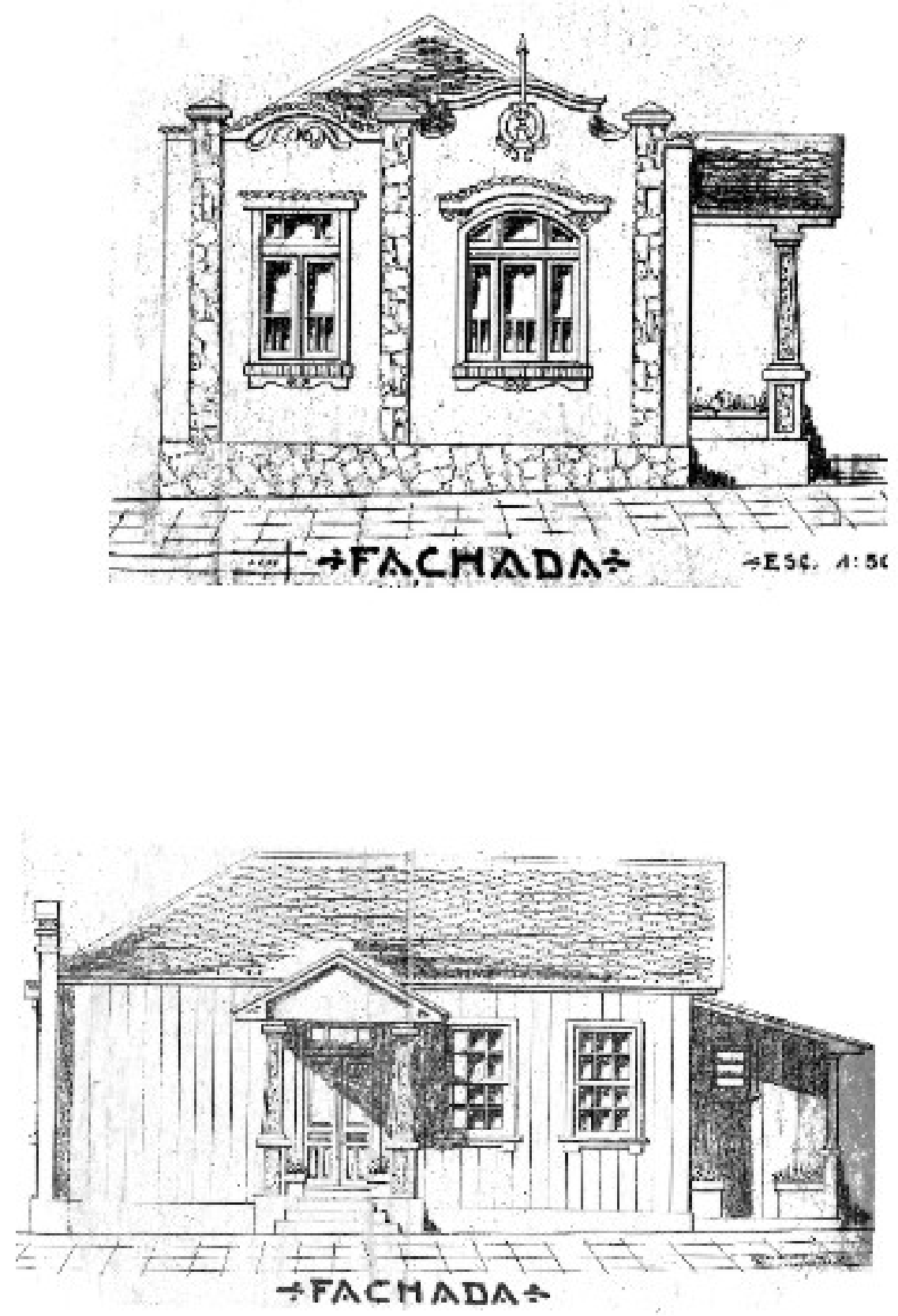

F005/46 - parte A

Casa de madeira mista

Ano de construção - 1946

Prop. - Ernesto Casagrande

Uso residencial

Fonte: prefeitura/2006

Obs. - fachada neocolonial e pórtico lateral típico 

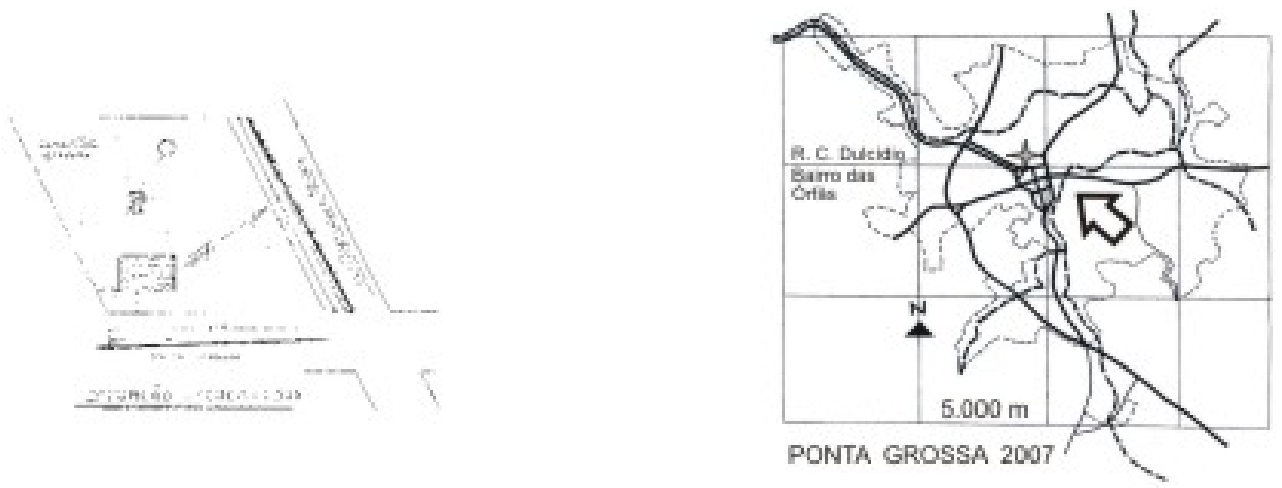

\section{Casa de imgDeiRa a SER CONSTRUIDA}

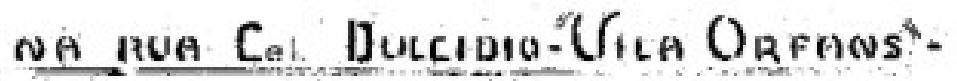
PARA O SR GILBERTO MARCAL
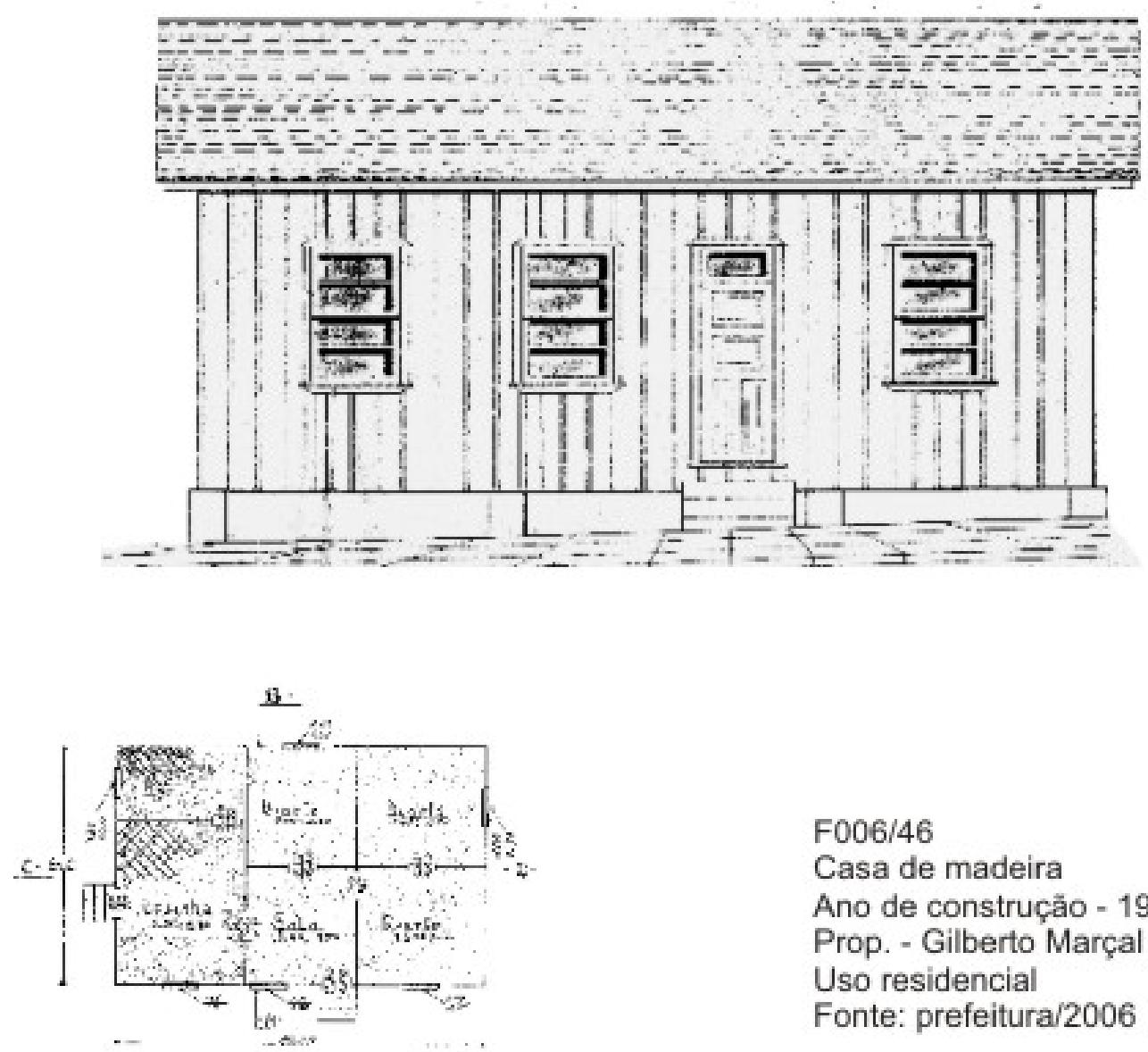

F006/46

Casa de madeira

Ano de construção - 1946

Prop. - Gilberto Marçal

Uso residencial

Fonte: prefeitura/2006

PLAGOTA IESL. t:100 

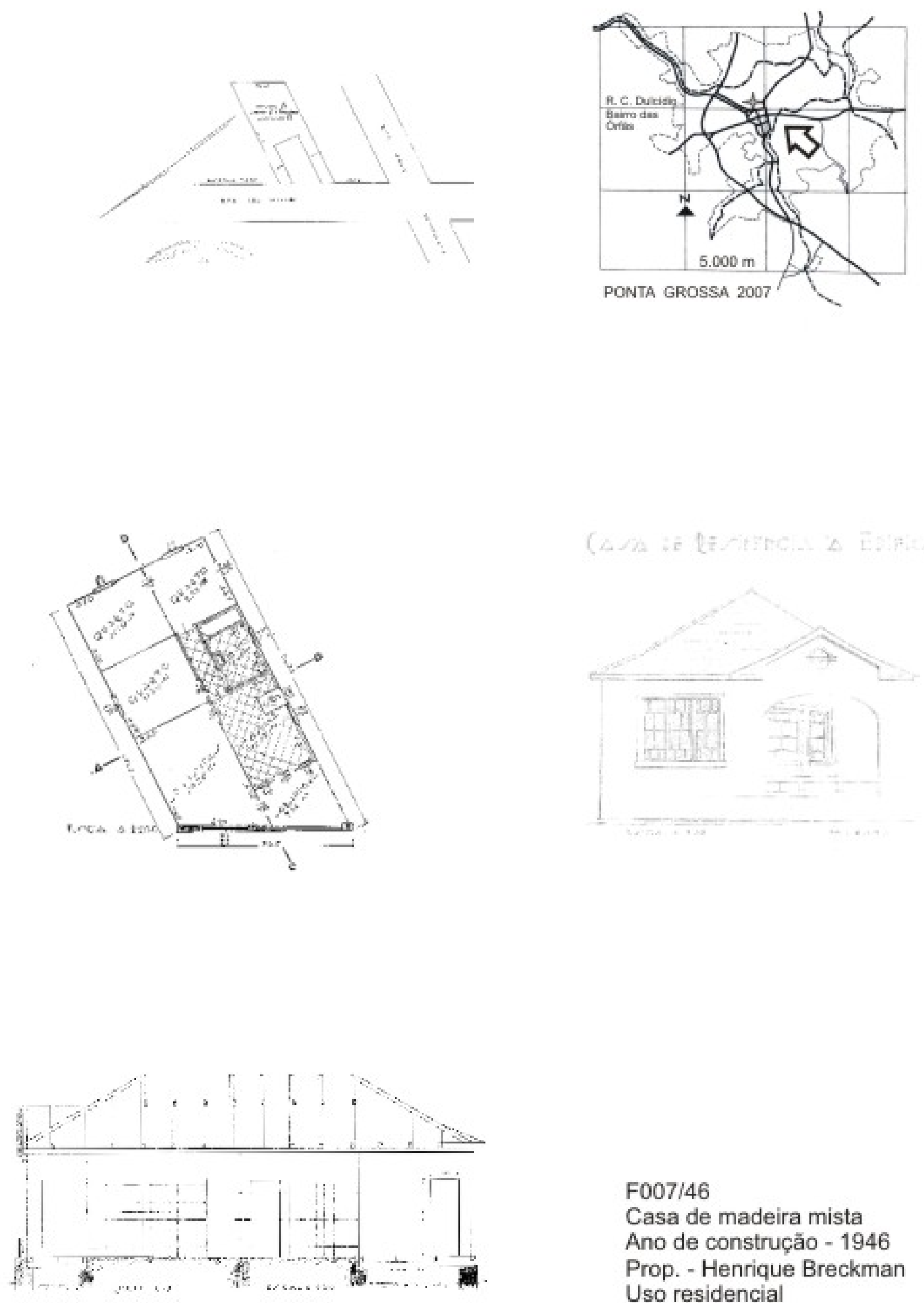

F007/46

Casa de madeira mista

Ano de construção - 1946

Prop. - Henrique Breckman Uso residencial

Fonte: prefeitura/2006 

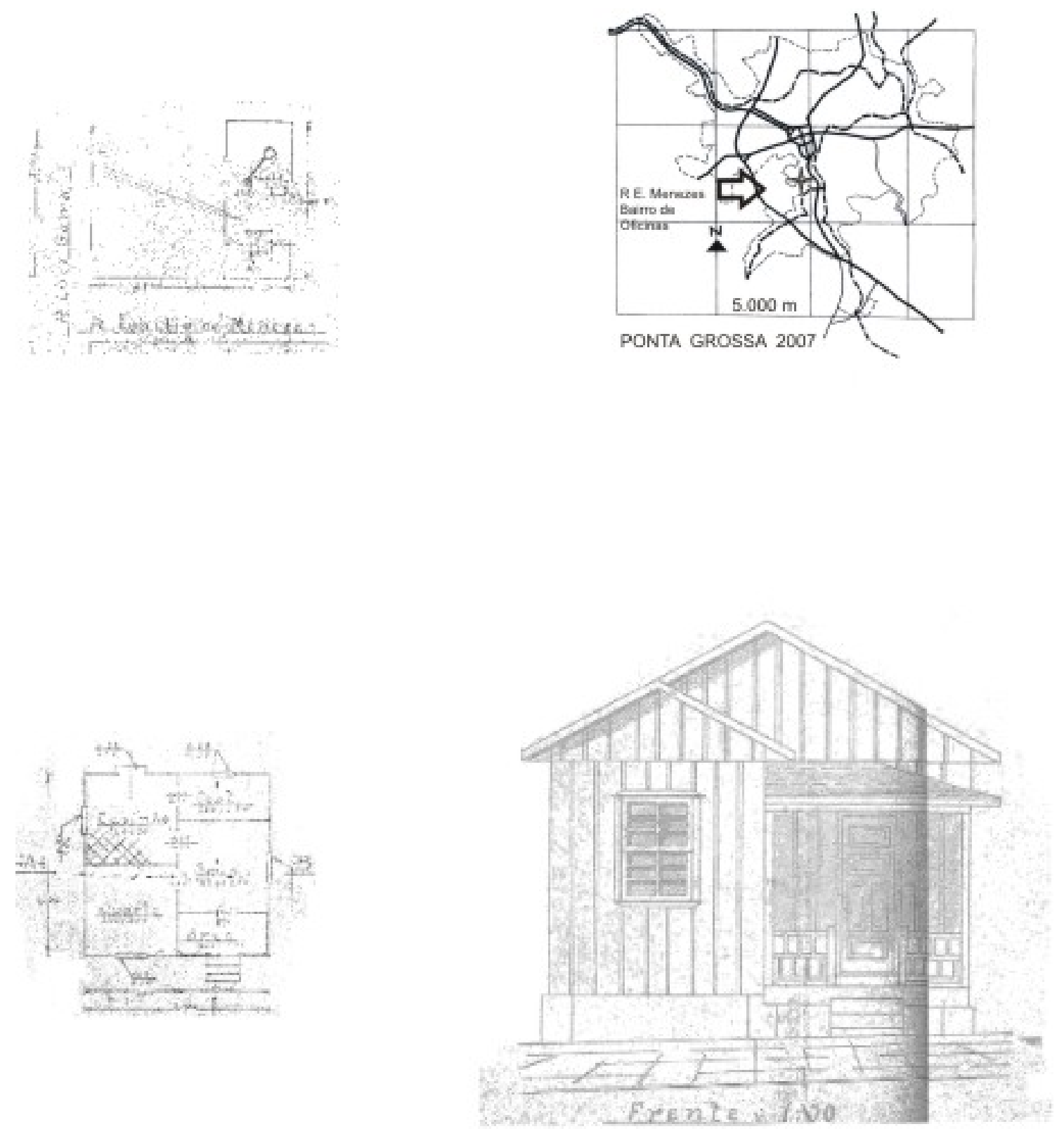

F008/46

Casa de madeira

Ano de construçäo - 1946

Prop. - João Cherigate

Uso residencial

Fonte: prefeitura/2006 

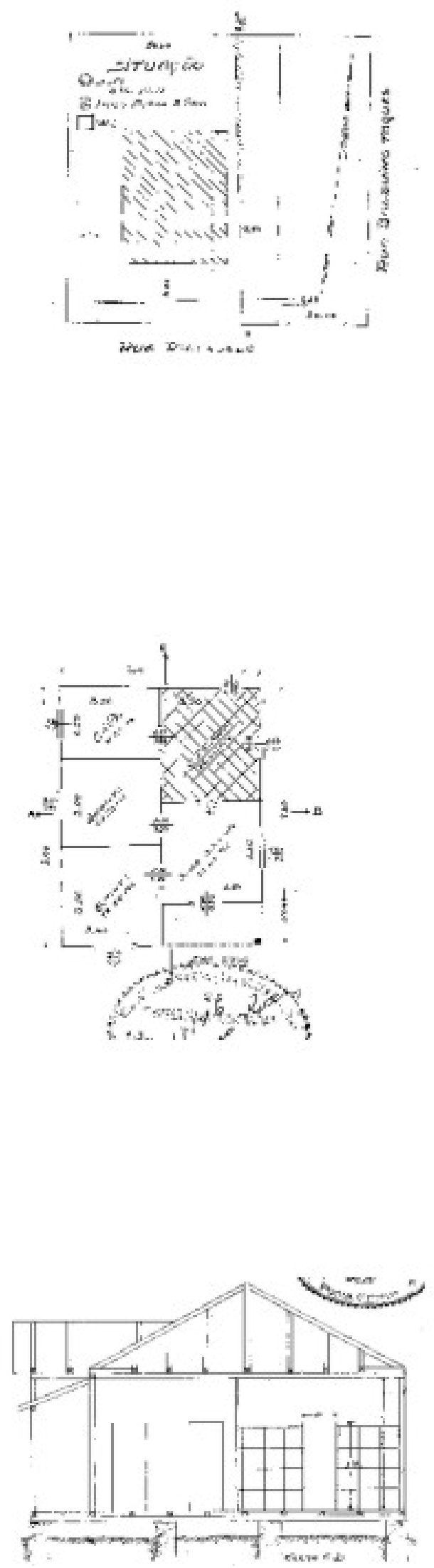
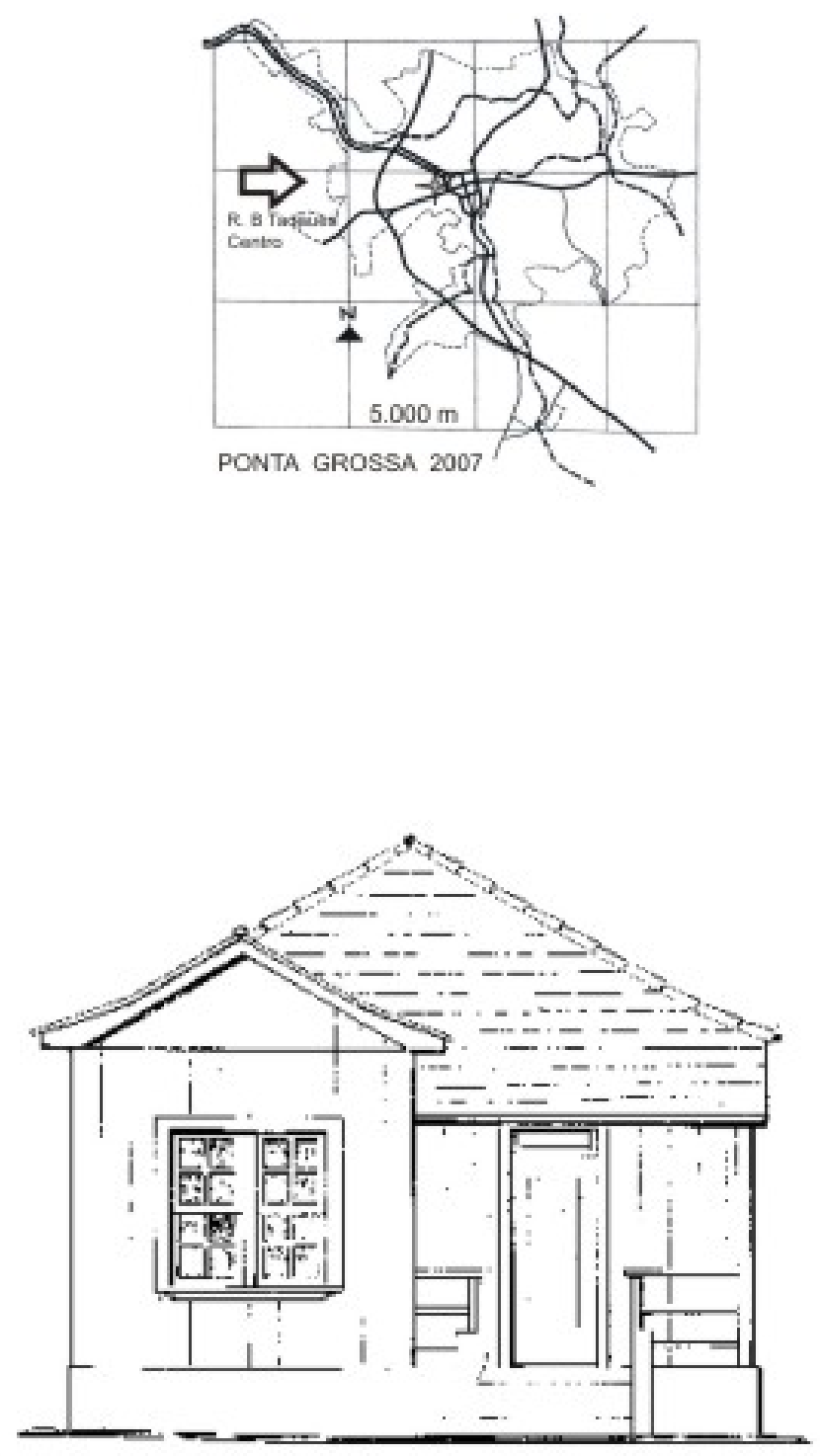

$\mathrm{F} 008 / 46$

Casa de madeira

Ano de construção - 1946

Prop. - Joăo Krechinski

Uso residencial

Fonte: prefeitura/2006

Obs.- Típico bangalô com planta bicameral 

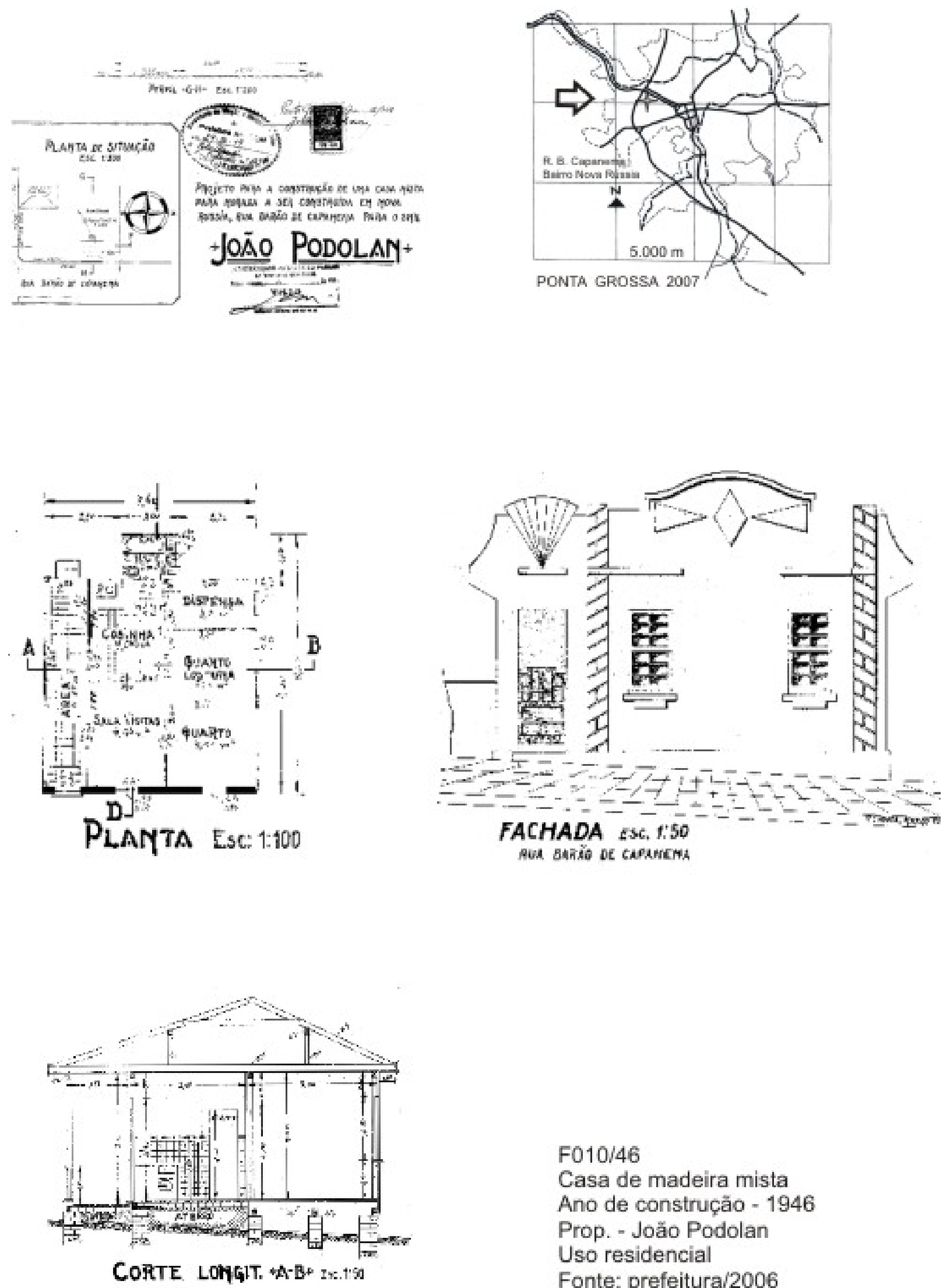

F010/46

Casa de madeira mista

Ano de construção - 1946

Prop. - João Podolan

Uso residencial

Fonte: prefeitura/2006 

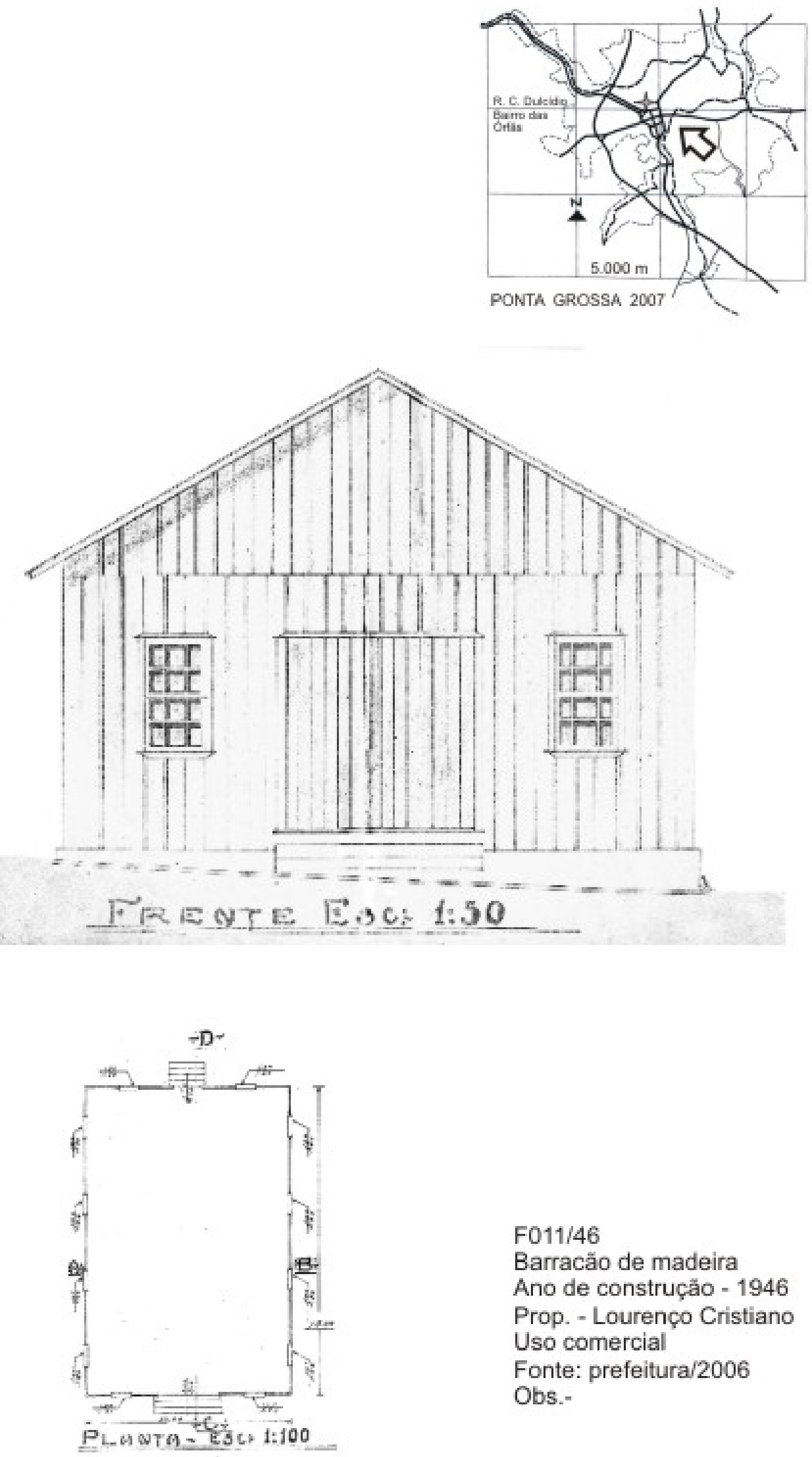

F011/46

Barracão de madeira

Ano de construçäo - 1946

Prop. - Lourenço Cristiano Uso comercial

Fonte: prefeitura/2006

Obs.- 

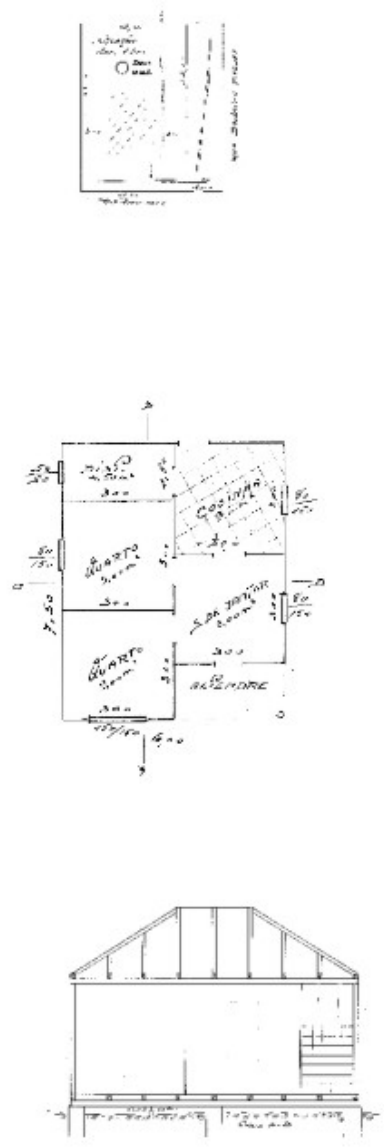
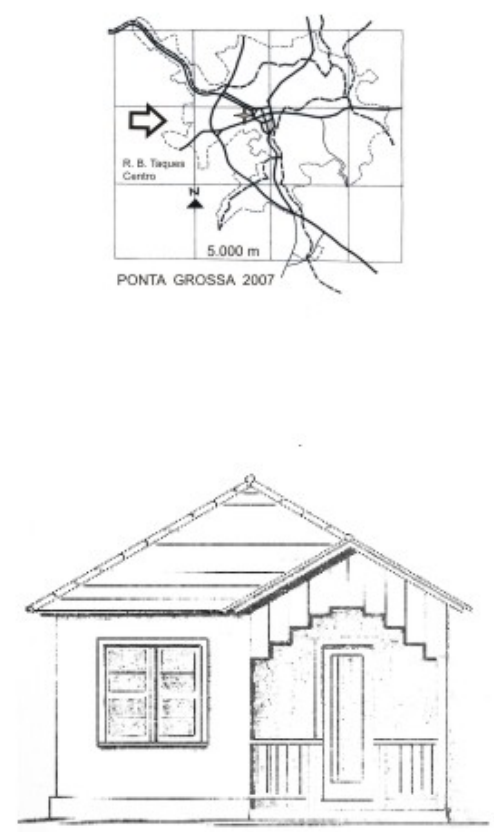

F012/46

Casa de madeira

Ano de construção - 1946

Prop. - Pedro Alquati

Uso residencial

Fonte: prefeitura/2006 

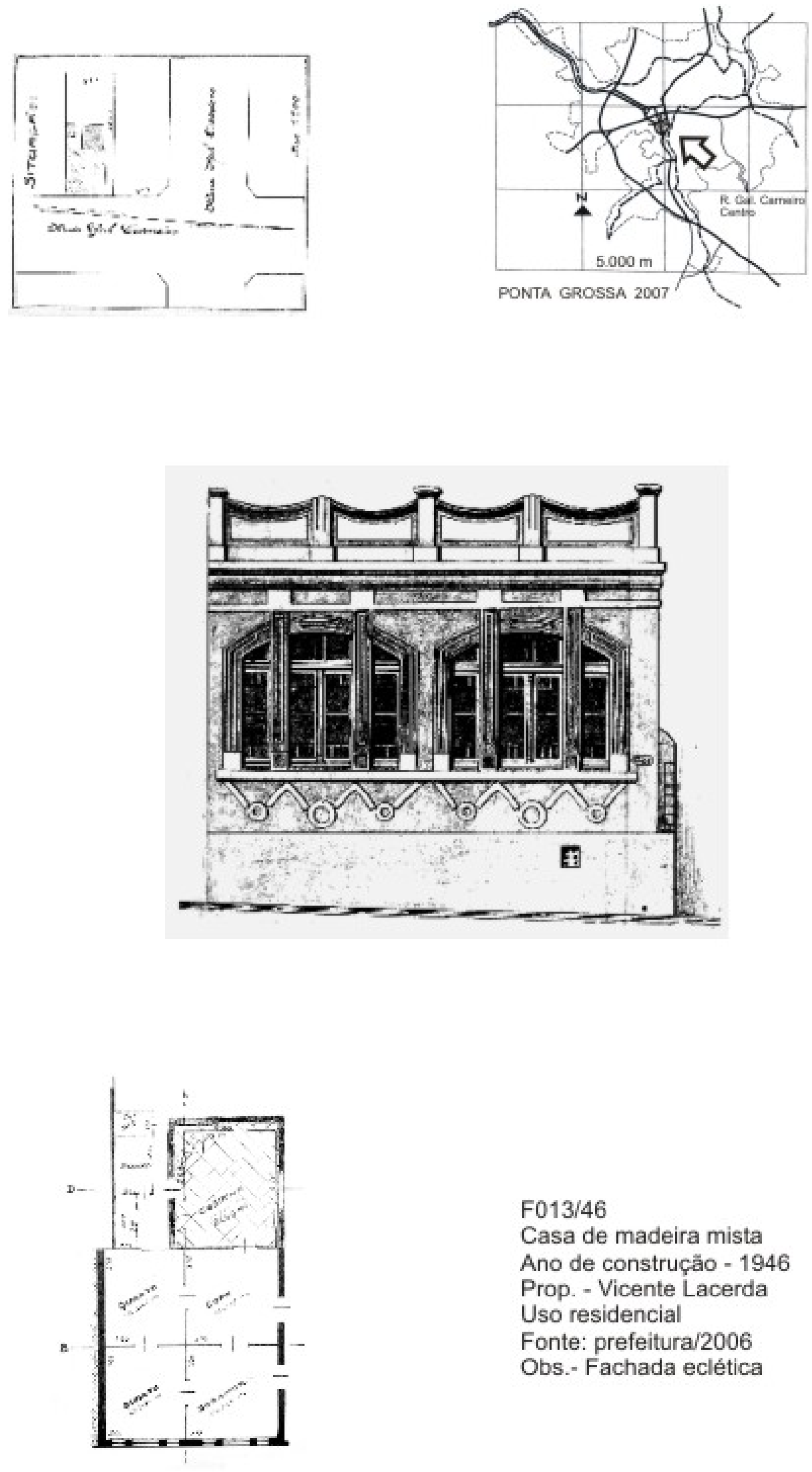

F013/46

Casa de madeira mista

Ano de construção - 1946

Prop. - Vicente Lacerda

Uso residencial

Fonte: prefeitura/2006

Obs.- Fachada eclética 

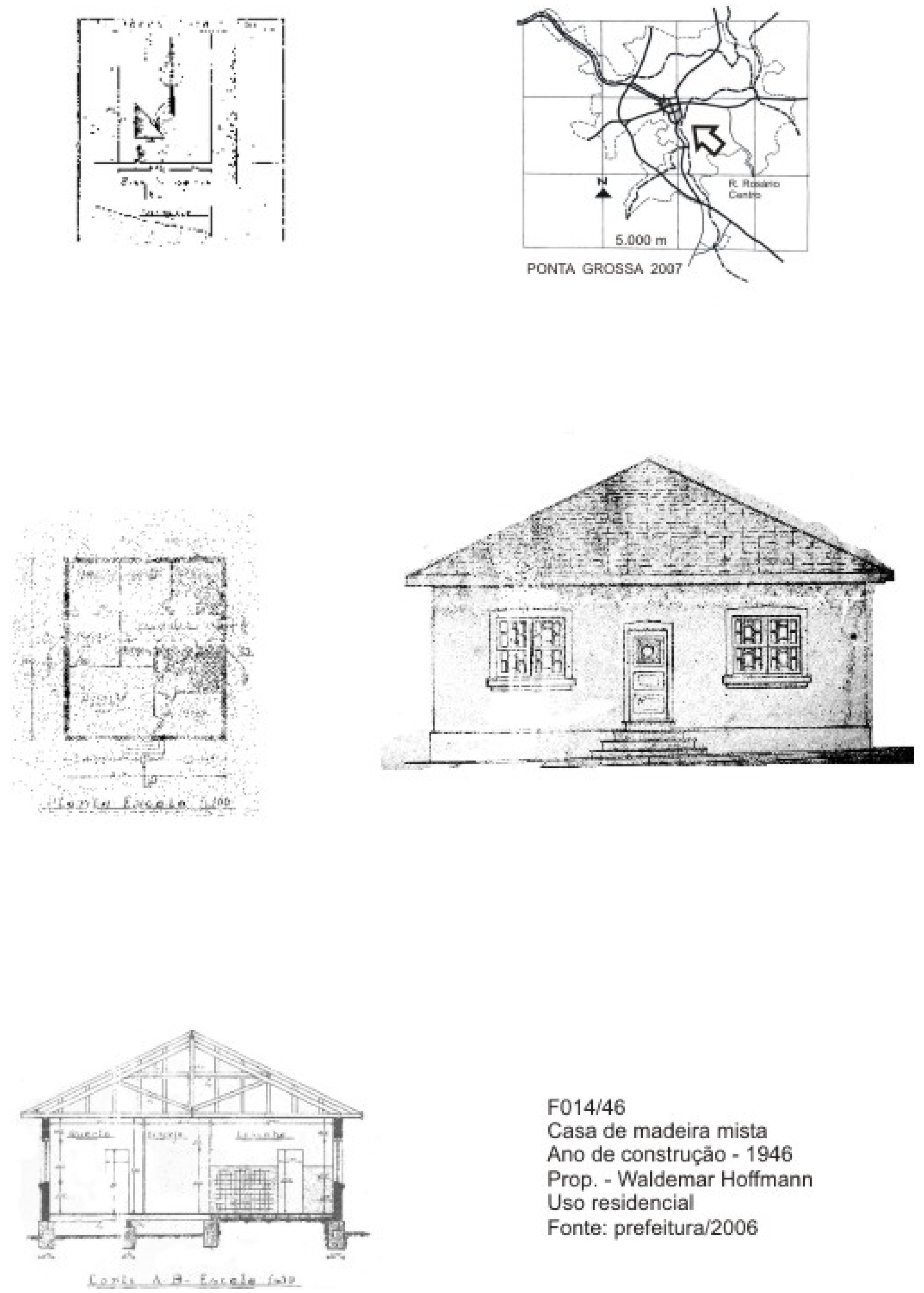

F014/46

Casa de madeira mista

Ano de construçăo - 1946

Prop. - Waldemar Hoffmann

Uso residencial

Fonte: prefeitura/2006 

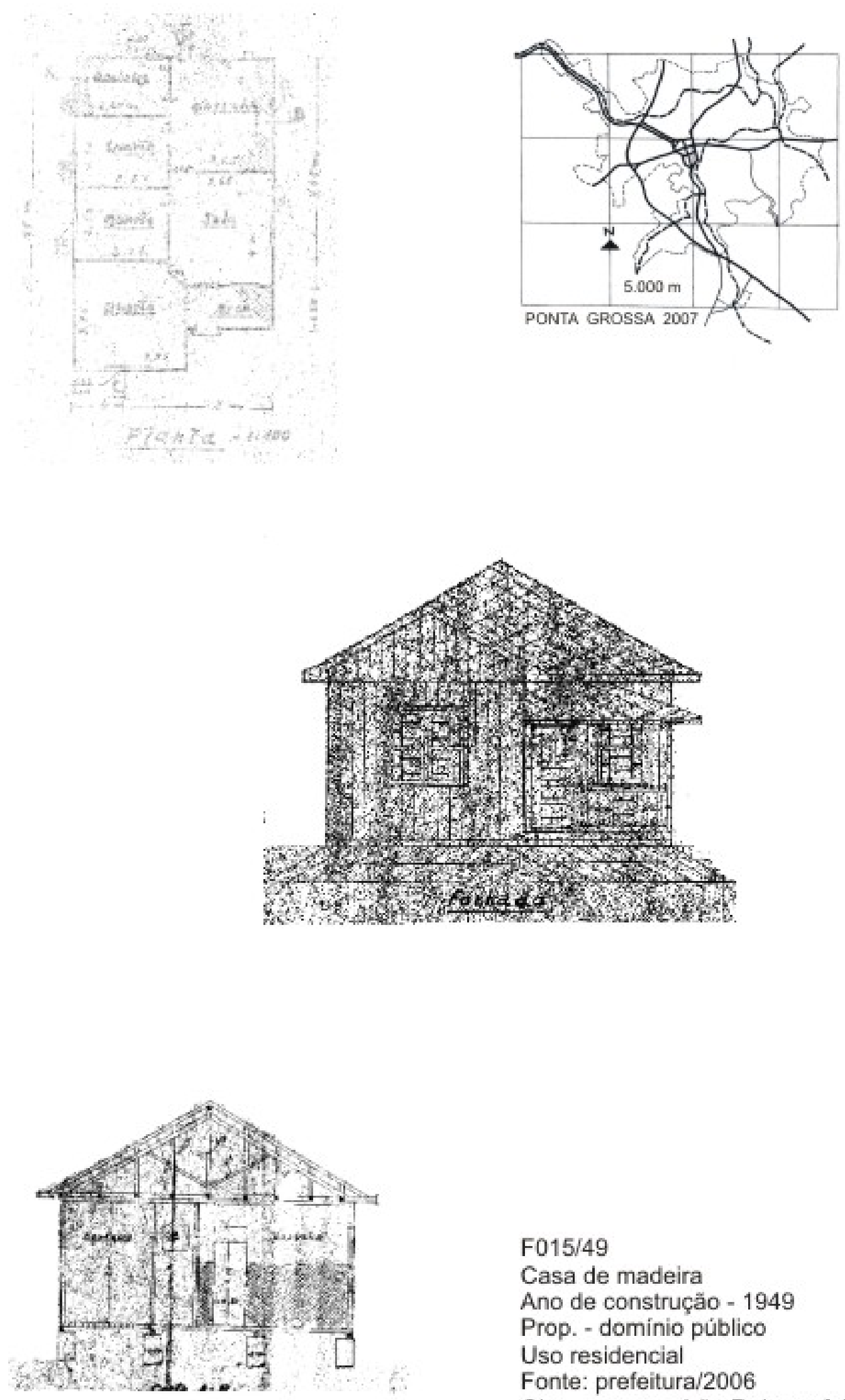

F015/49

Casa de madeira

Ano de construção - 1949

Prop. - domínio público

Uso residencial

Fonte: prefeitura/2006

Obs. - casa padrão $\mathrm{R}$ da prefeitura 
LEVANTAMENTO DE PROJETOS DE CASAS DE MADEIRA APROVADOS NA PREFEITURA DE PONTA GROSSA NA DÉCADA DE 1950 


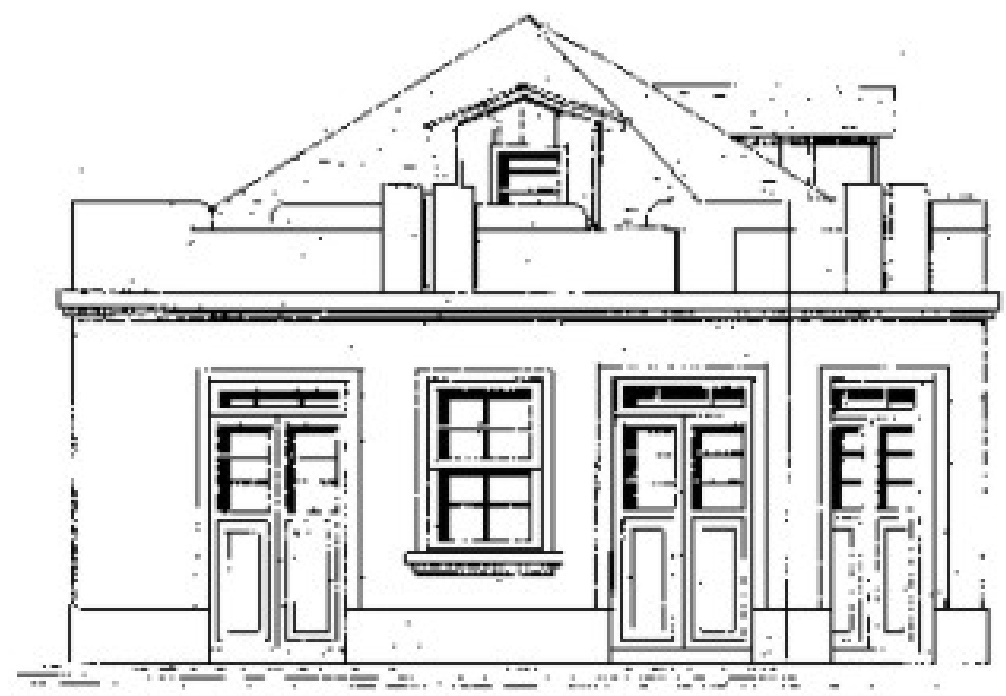

FACHADA FRONTAL I:5O

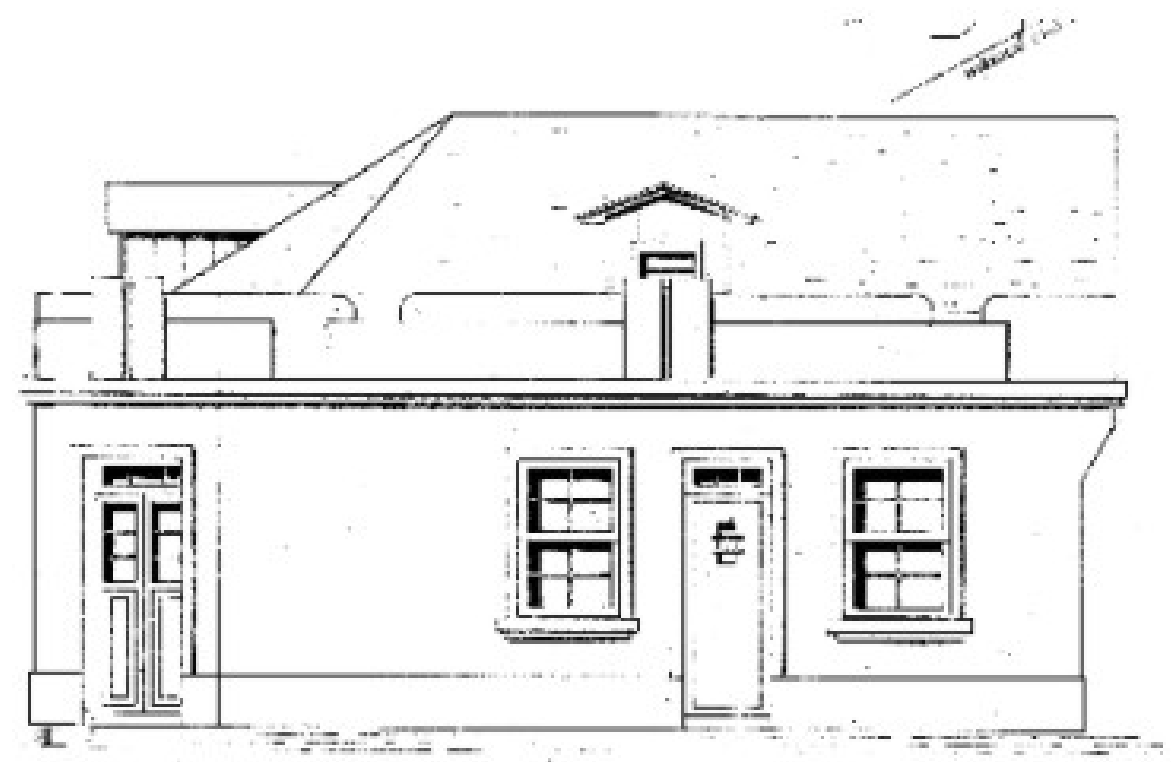

FACHADA LATERAL I:50

F001/51- parte 1

Casa de madeira mista

Ano de construçăo - 1951

Prop. - Manoel M. Oliveira

Uso residencial e comercial

Fonte: prefeitura/2006

Obs. - típico comércio de

esquina de bairro 

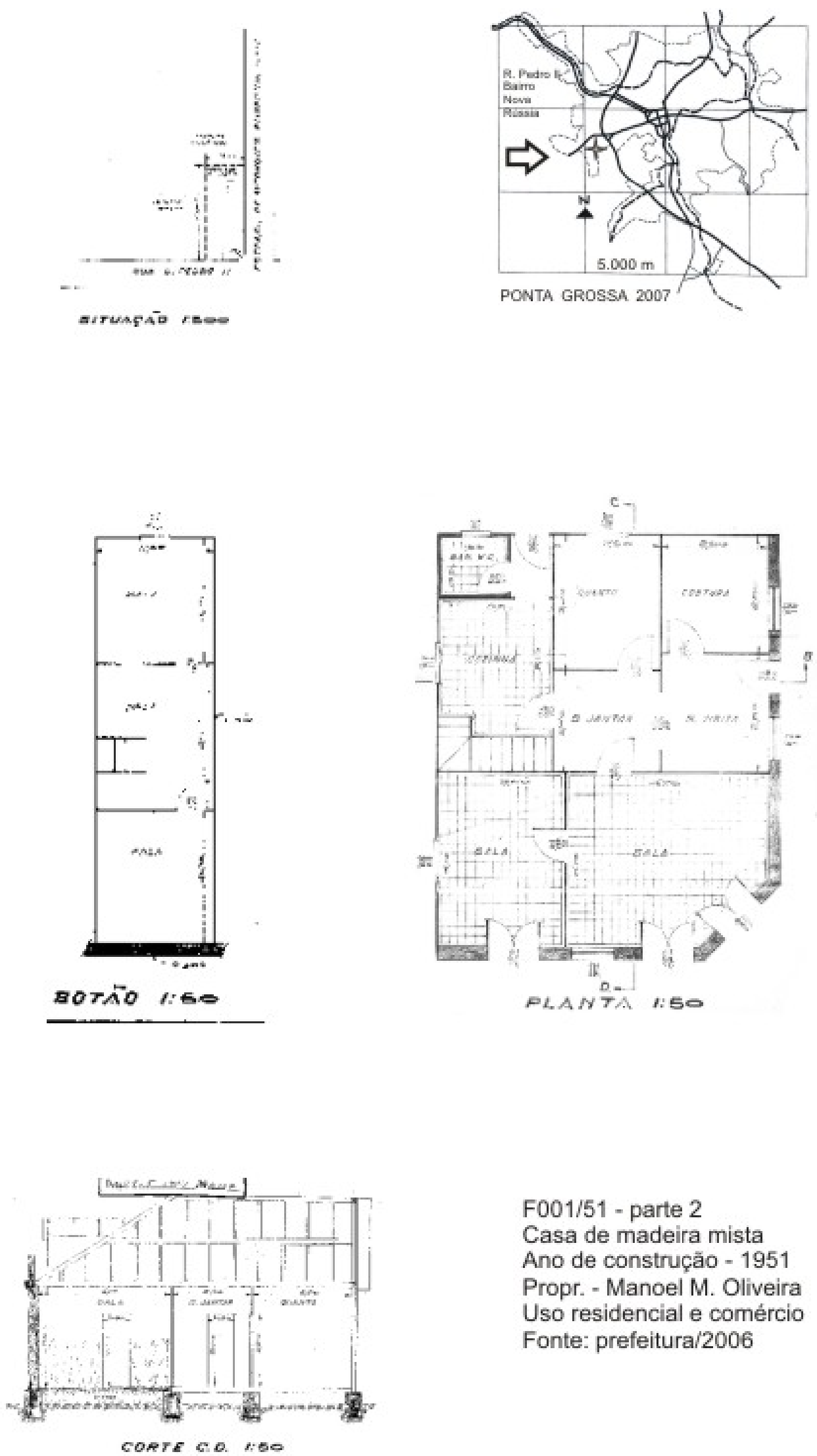

F001/51 - parte 2

Casa de madeira mista

Ano de construção - 1951

Propr. - Manoel M. Oliveira Uso residencial e comércio

Fonte: prefeitura/2006 

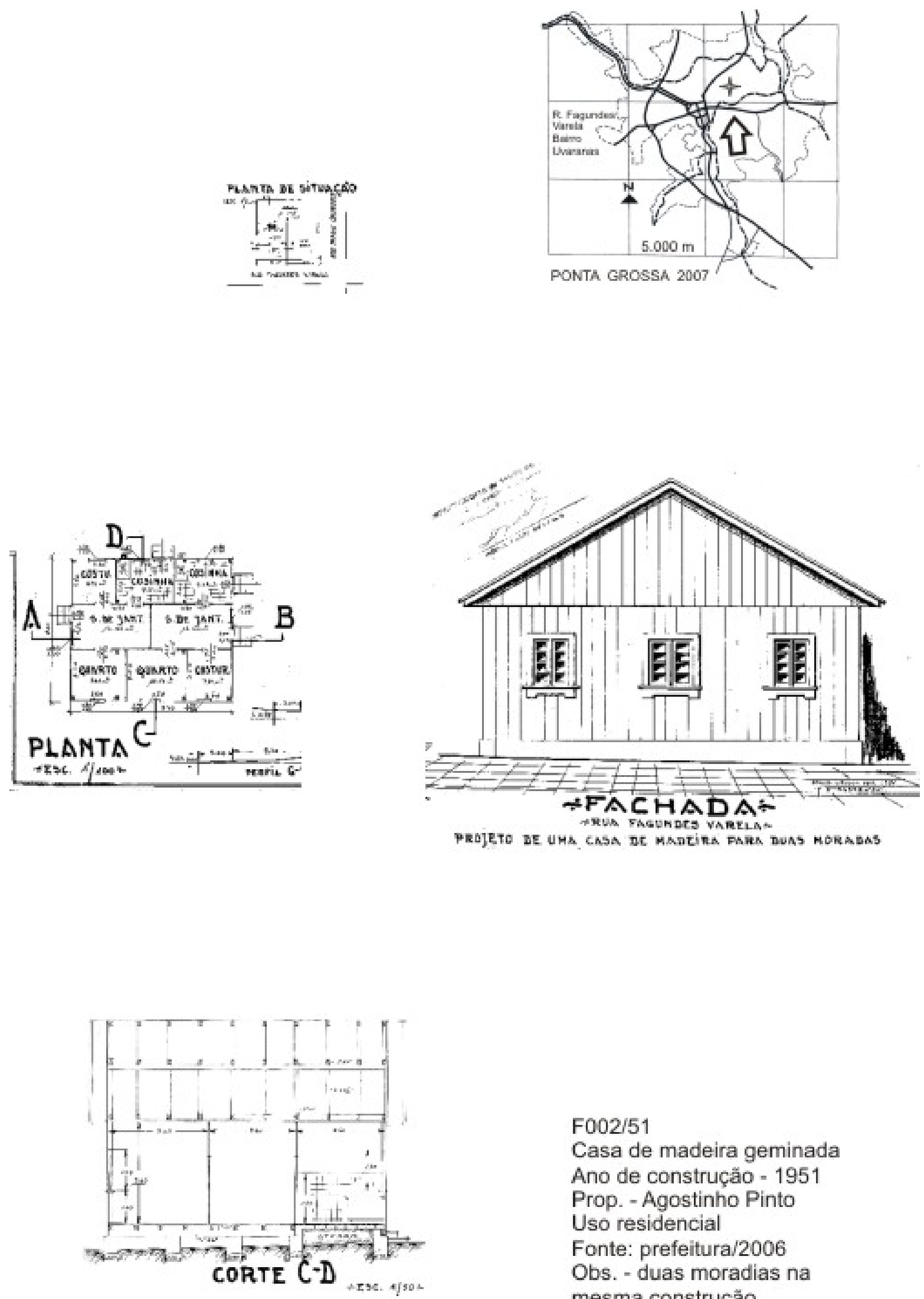

F002/51

Casa de madeira geminada

Ano de construção - 1951

Prop. - Agostinho Pinto

Uso residencial

Fonte: prefeitura/2006

Obs. - duas moradias na

mesma construçăo 

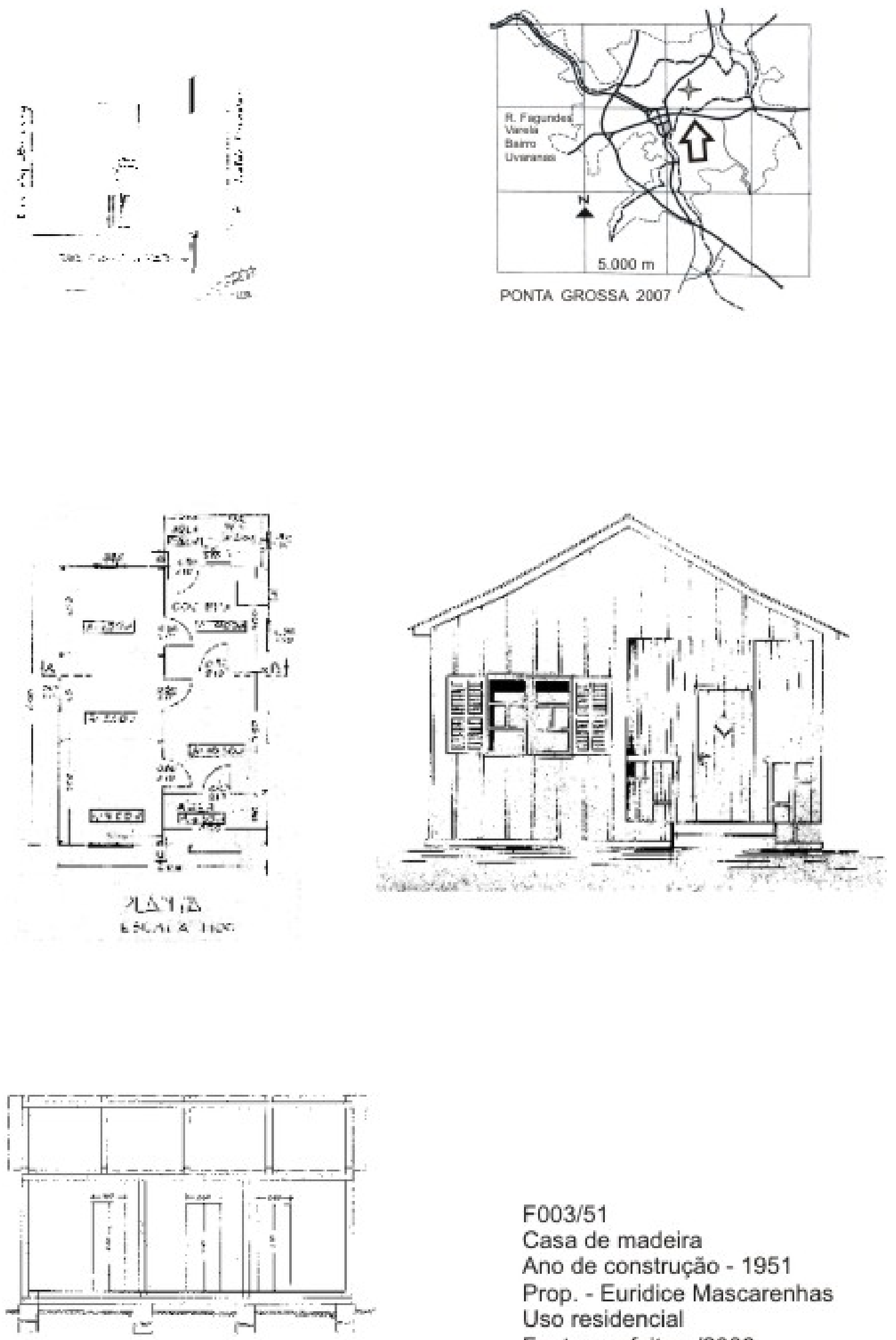

F003/51

Casa de madeira

Ano de construção - 1951

Prop. - Euridice Mascarenhas Uso residencial

Fonte: prefeitura/2006 

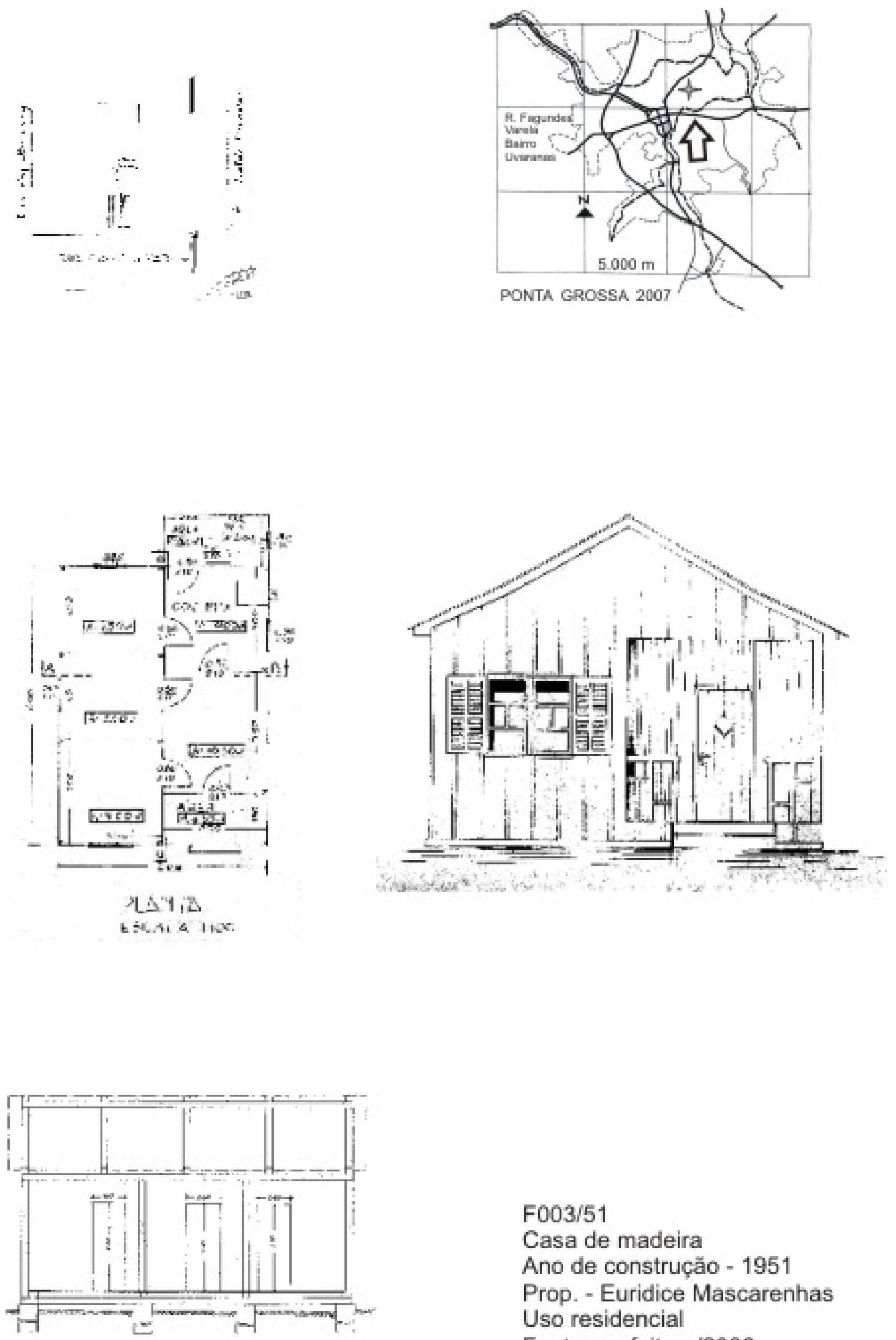

F003/51

Casa de madeira

Ano de construção - 1951

Prop. - Euridice Mascarenhas Uso residencial

Fonte: prefeitura/2006 

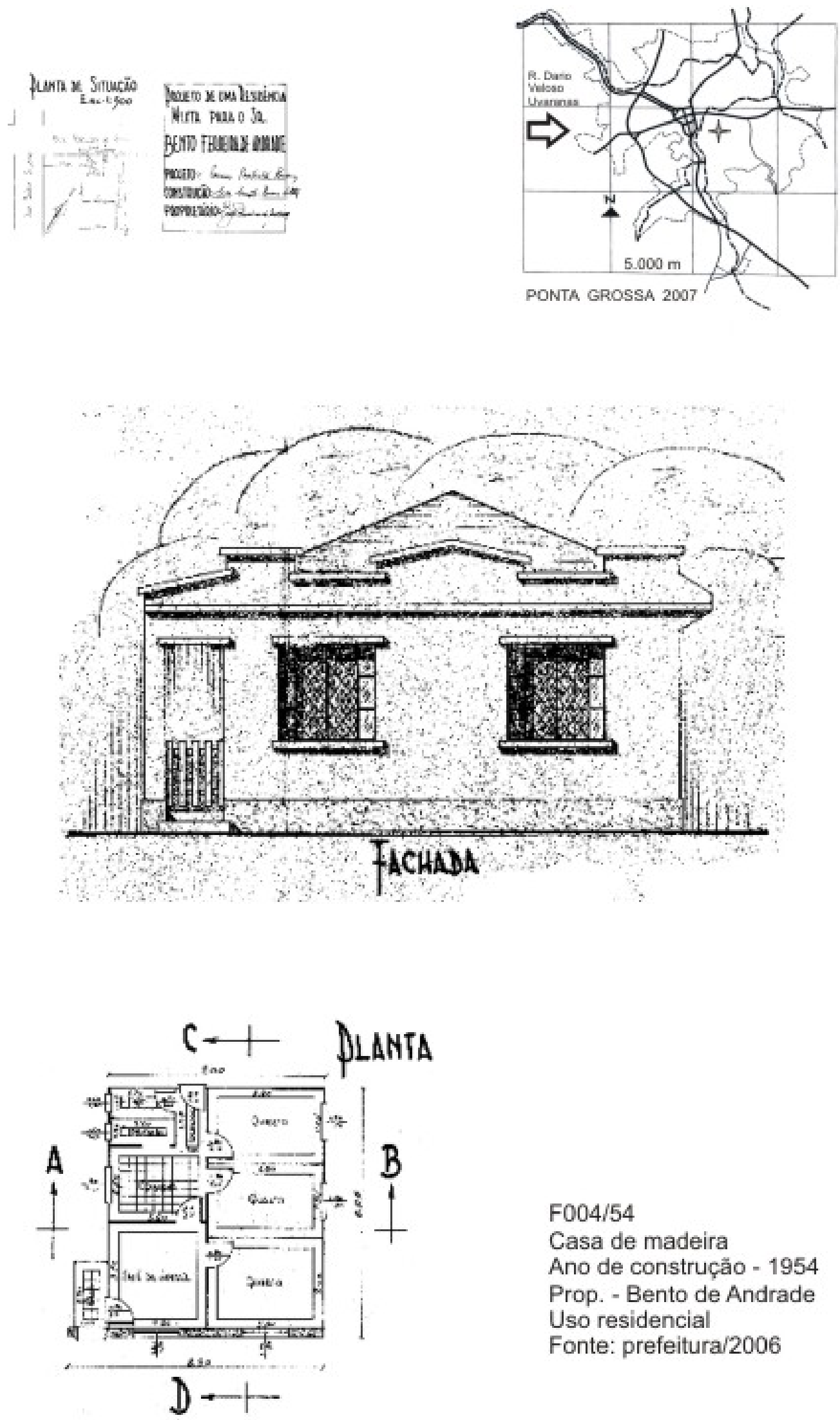

F004/54

Casa de madeira

Ano de construçăo - 1954

Prop. - Bento de Andrade

Uso residencial

Fonte: prefeitura/2006 

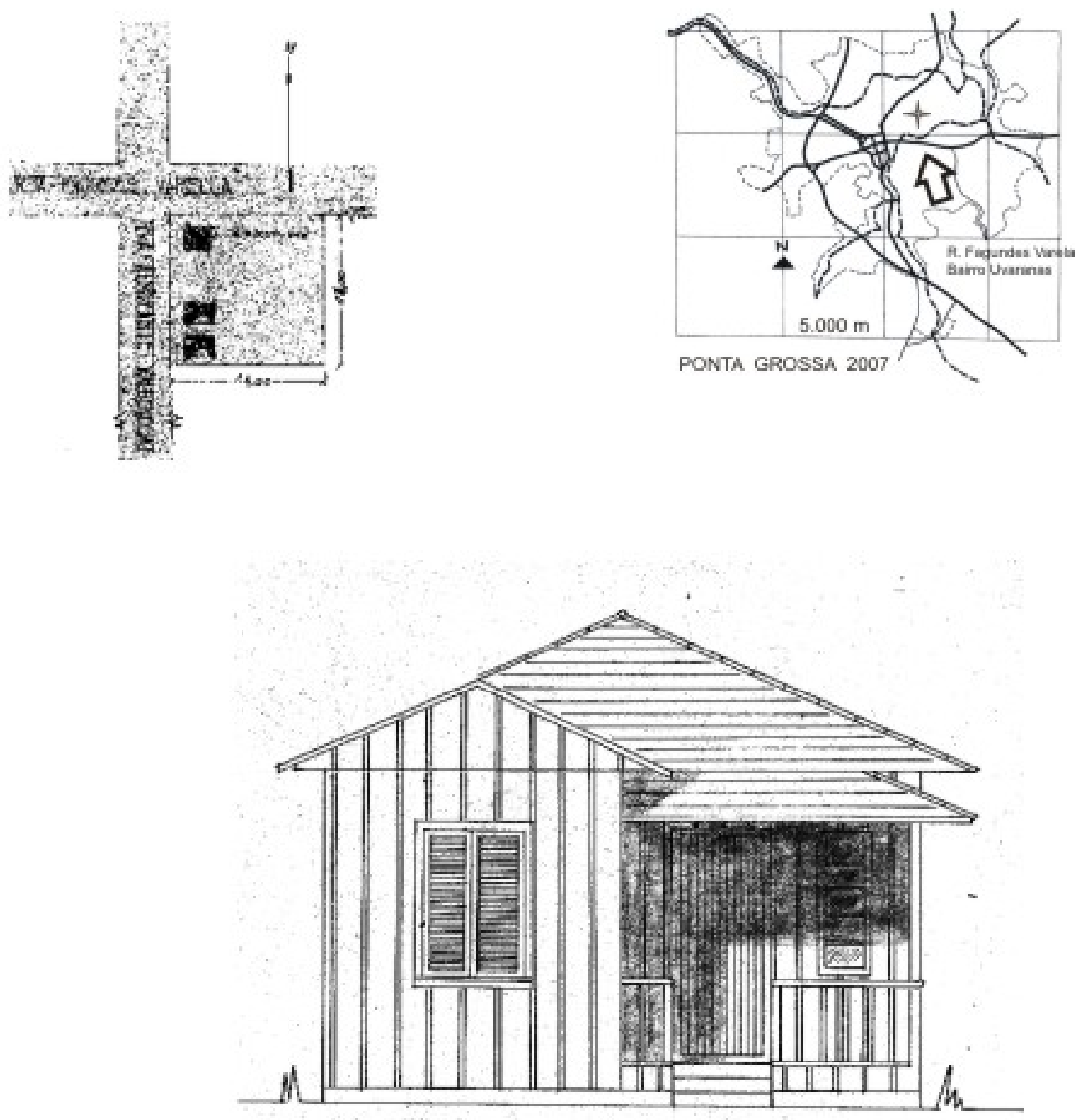

FACHADA $\cdot 1: 50$

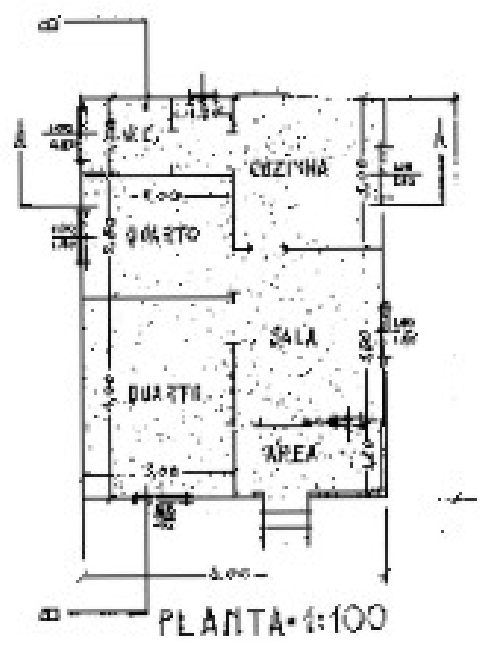

F005/54

Casa de madeira

Ano de construção - 1954

Prop. - Virgilio Brisola

Uso residencial

Fonte: prefeitura/2006 

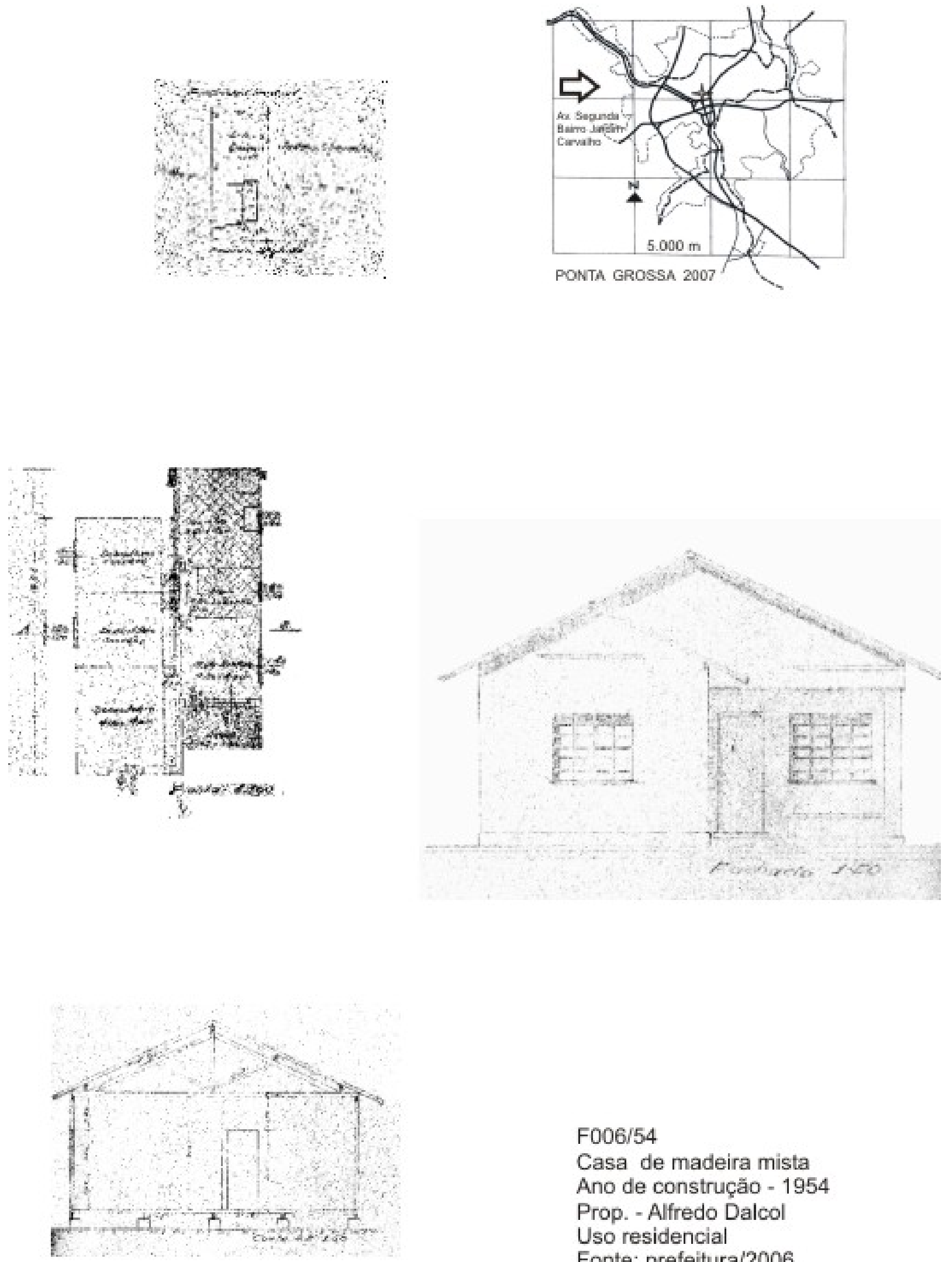

F006/54

Casa de madeira mista

Ano de construção - 1954

Prop. - Alfredo Dalcol

Uso residencial

Fonte: prefeitura/2006

Obs. - fachada em alvenaria 

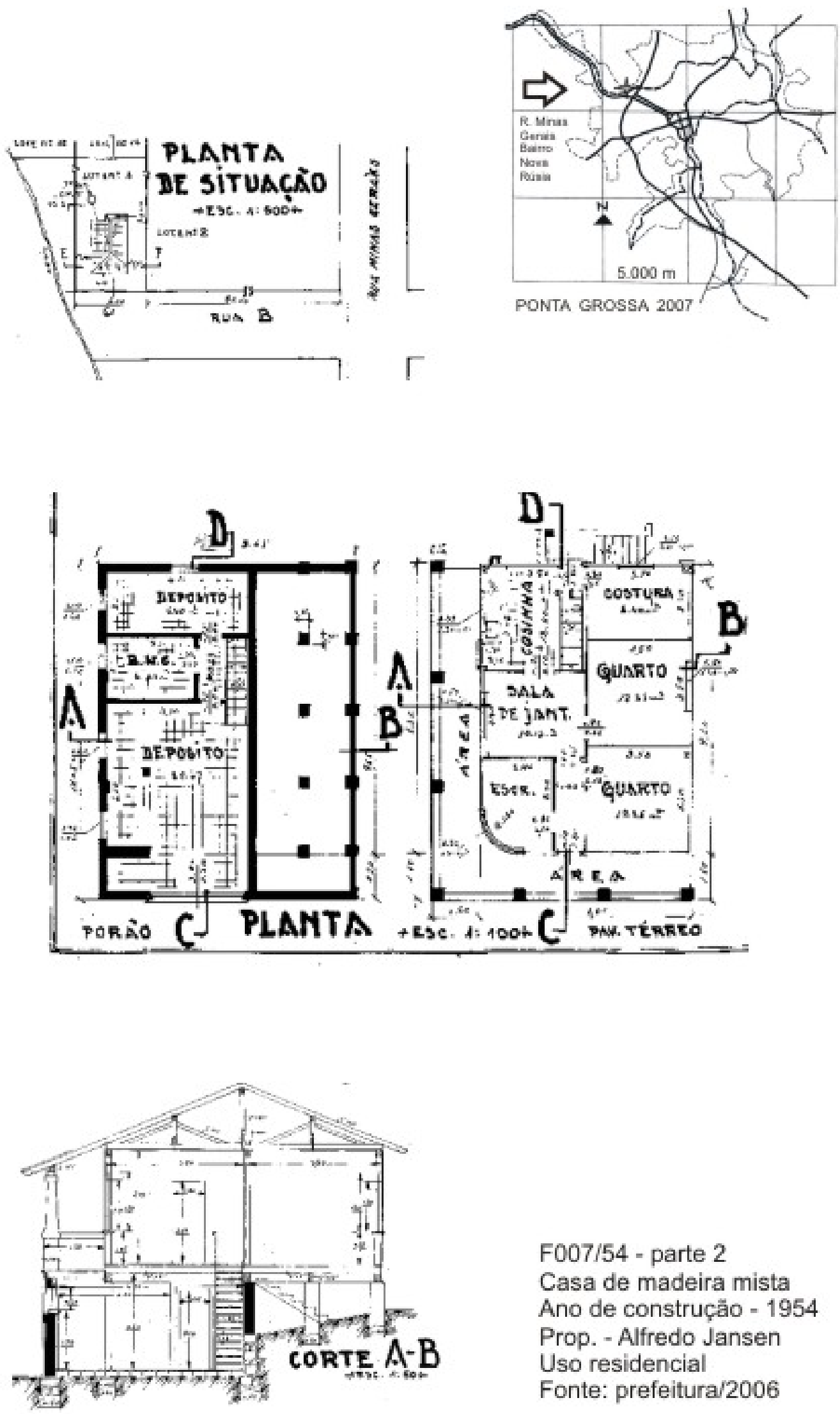

F007/54 - parte 2

Casa de madeira mista

Ano de construçăo - 1954

Prop. - Alfredo Jansen

Uso residencial

Fonte: prefeitura/2006 

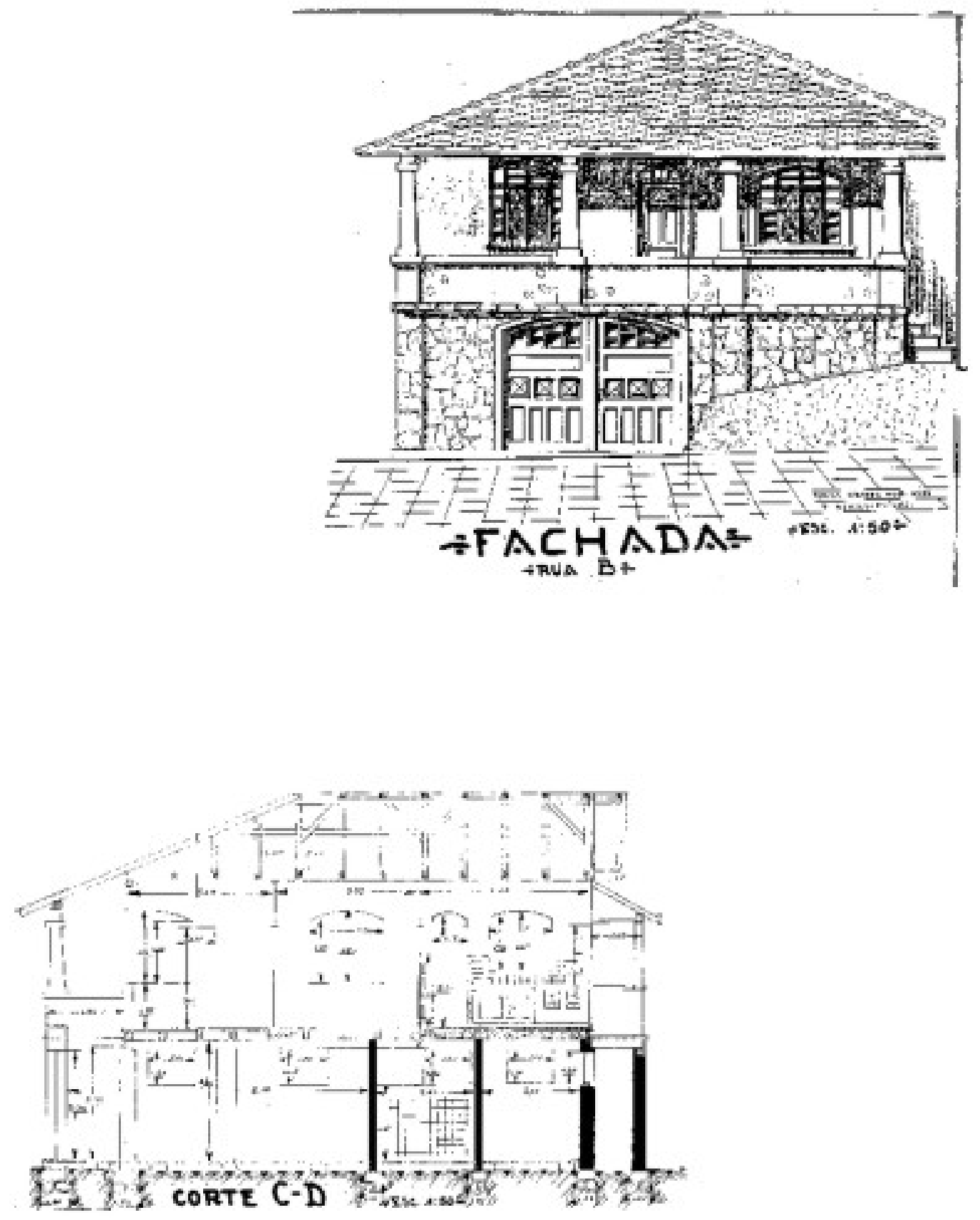

F007/54 - parte 1

Casa de madeira mista

Ano de construçăo - 1954

Proprietário - Alfredo Jansen

Uso residencial

Fonte: prefeitura/2006 

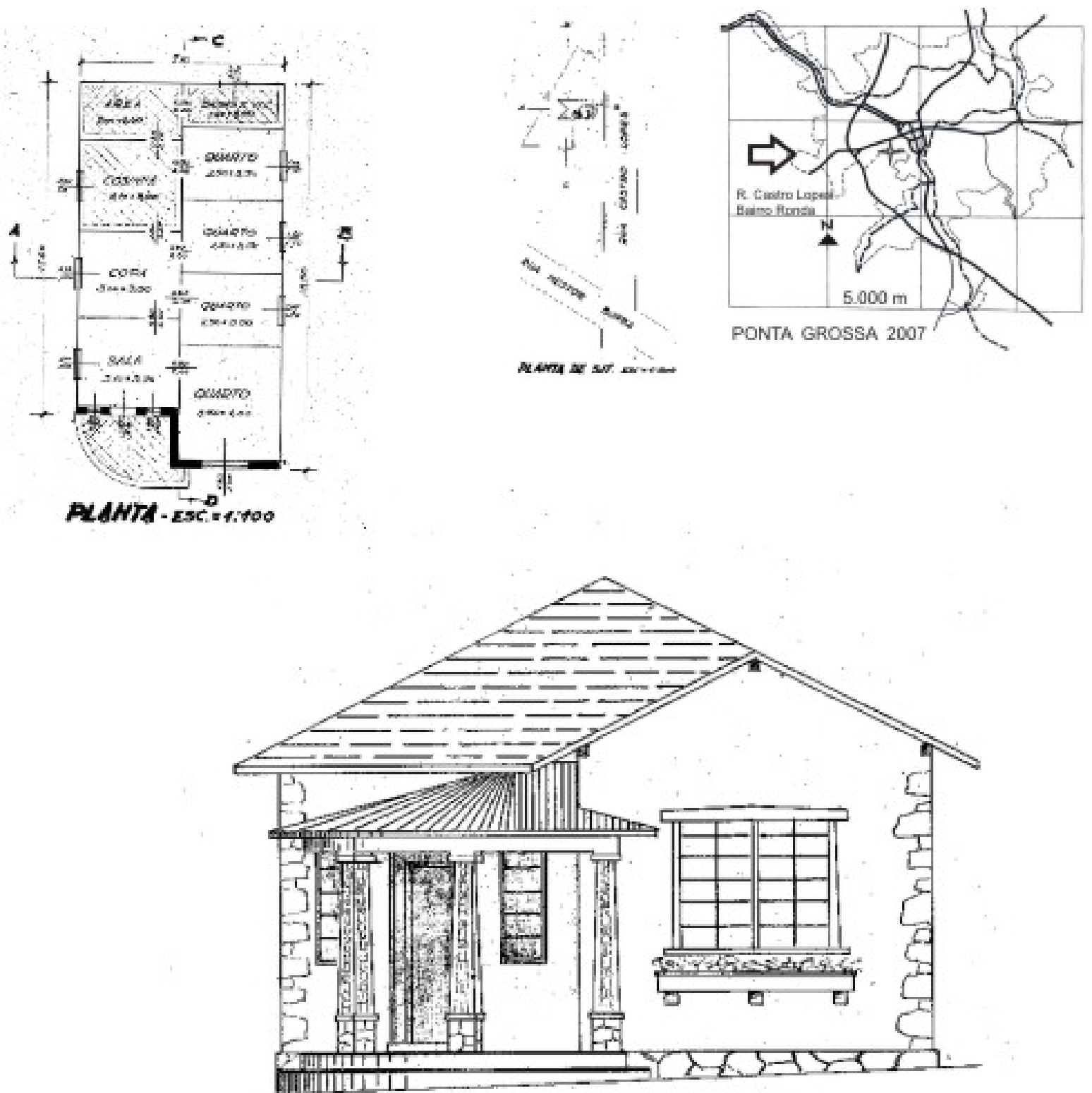

FACHADA-ESC, $=1: 50$

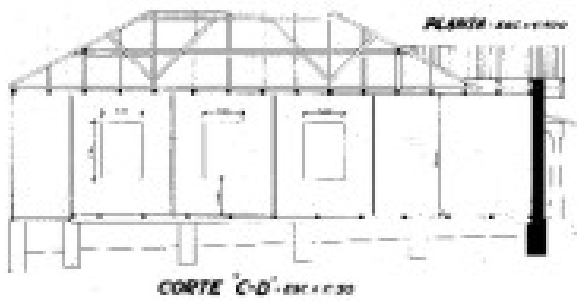

F008/54

Casa de madeira mista

Ano de construçăo - 1954

Prop. - Alfredo Justus

Uso residencial

Fonte: prefeitura/2006

Obs. - fachada em alvenaria 

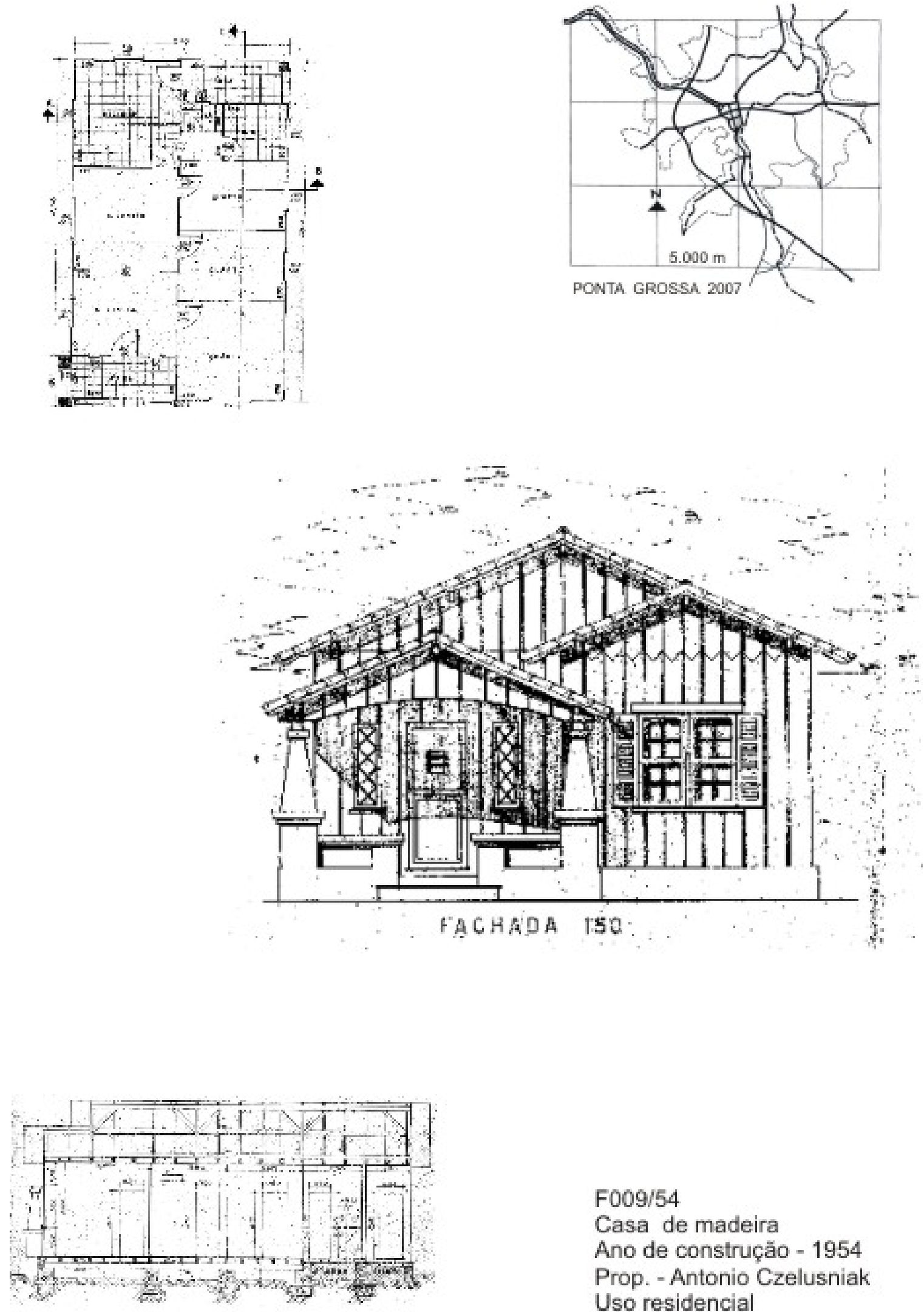

F009/54

Casa de madeira

Ano de construção - 1954

Prop. - Antonio Czelusniak Uso residencial

Fonte: prefeitura/2006 

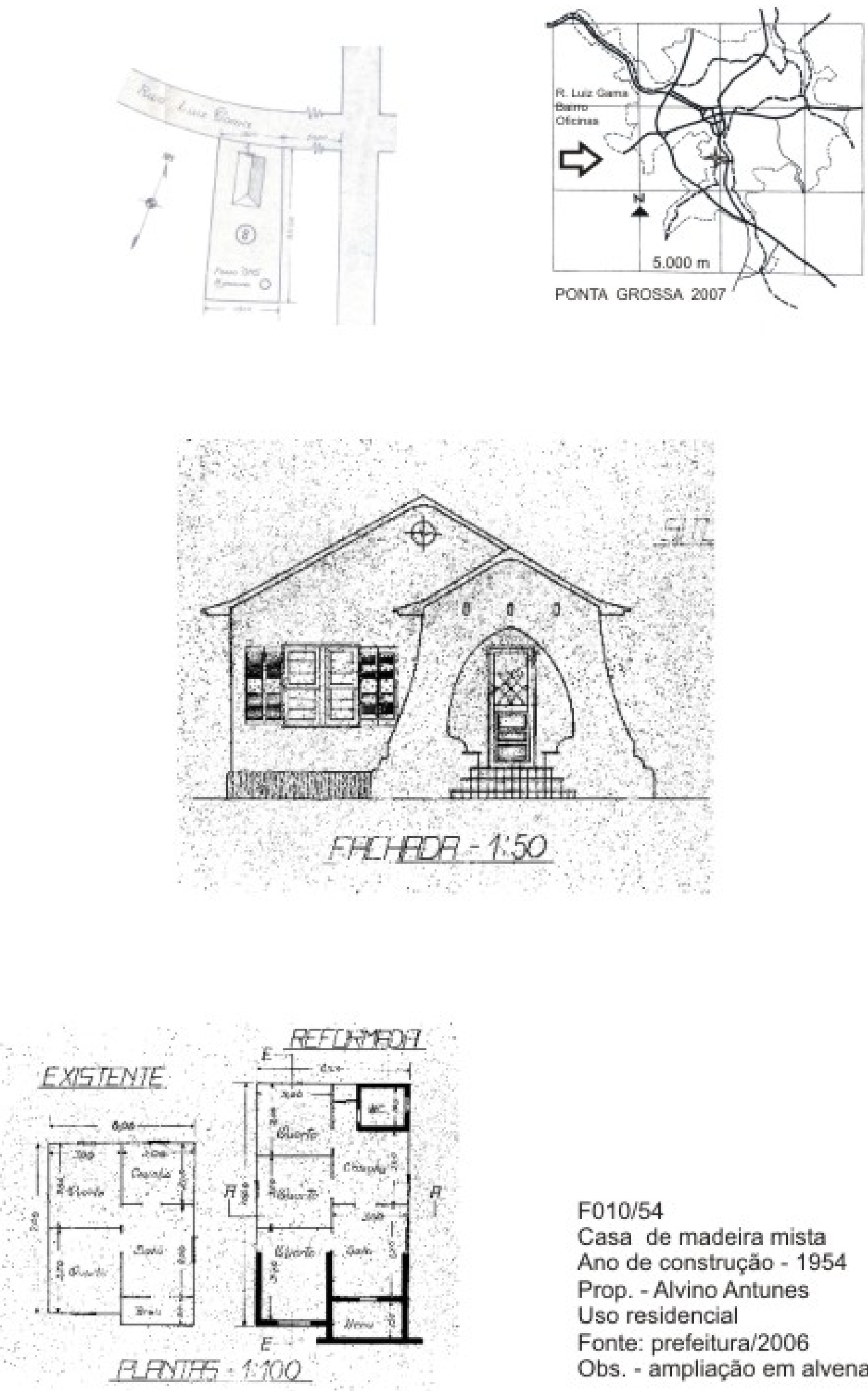

F010/54

Casa de madeira mista Ano de construção - 1954

Prop. - Alvino Antunes Uso residencial Fonte: prefeitura/2006 Obs. - ampliação em alvenaria 

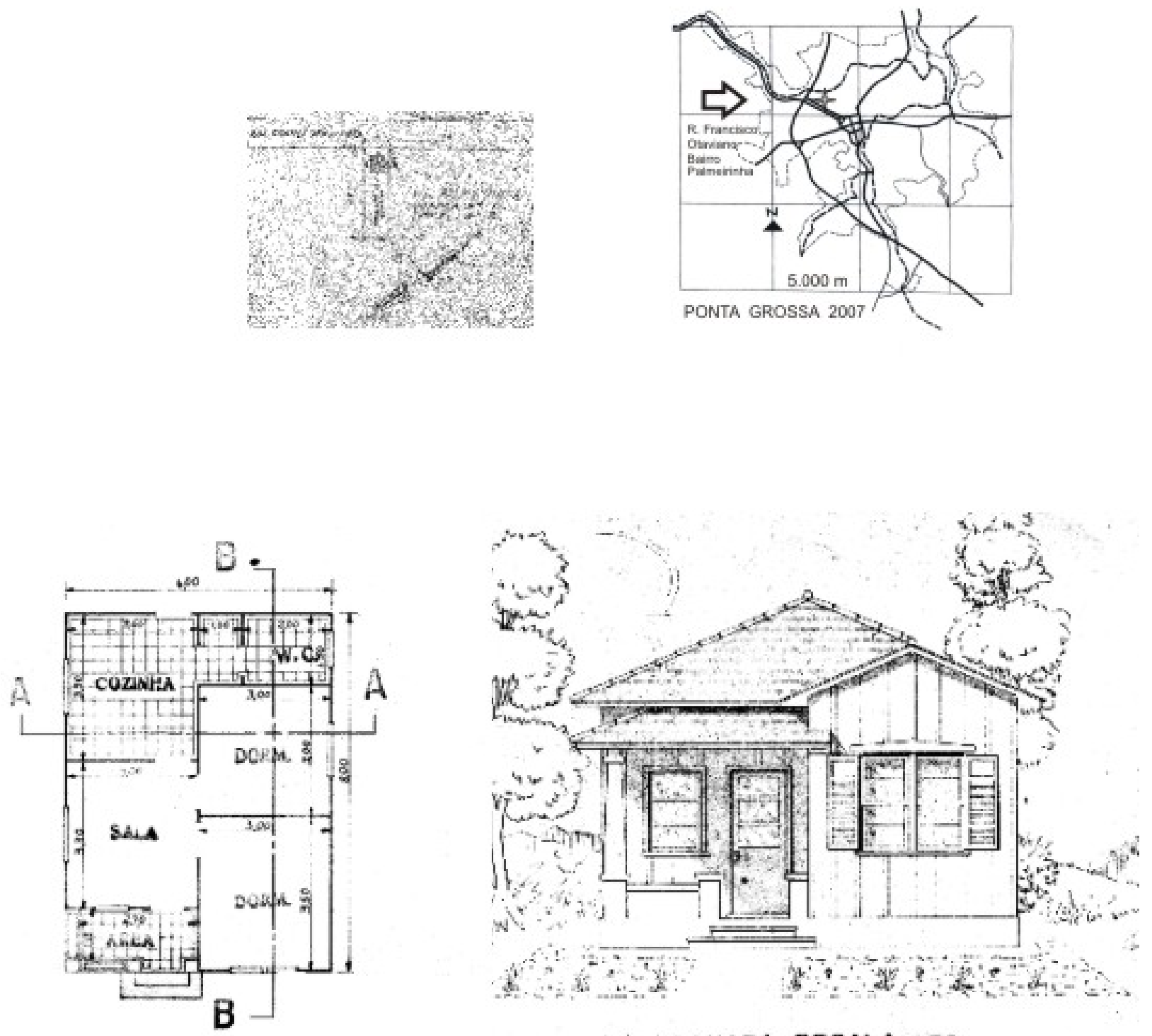

FACHADA-ESCALA 1.50

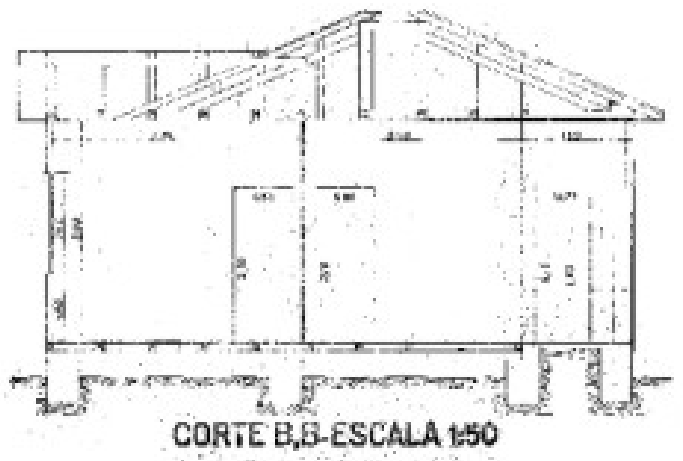

F011/54

Casa de madeira

Ano de construção - 1954

Prop. - Angelo Borsato

Uso residencial

Fonte: prefeitura/2006

Obs. - típico bangalô 

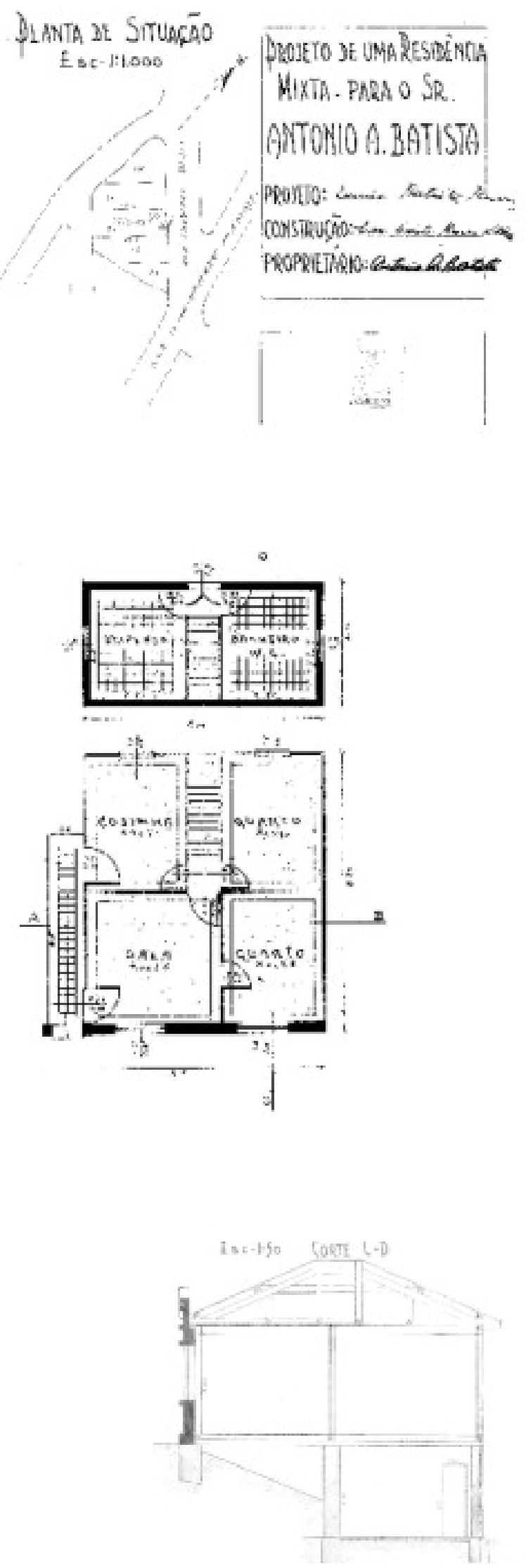
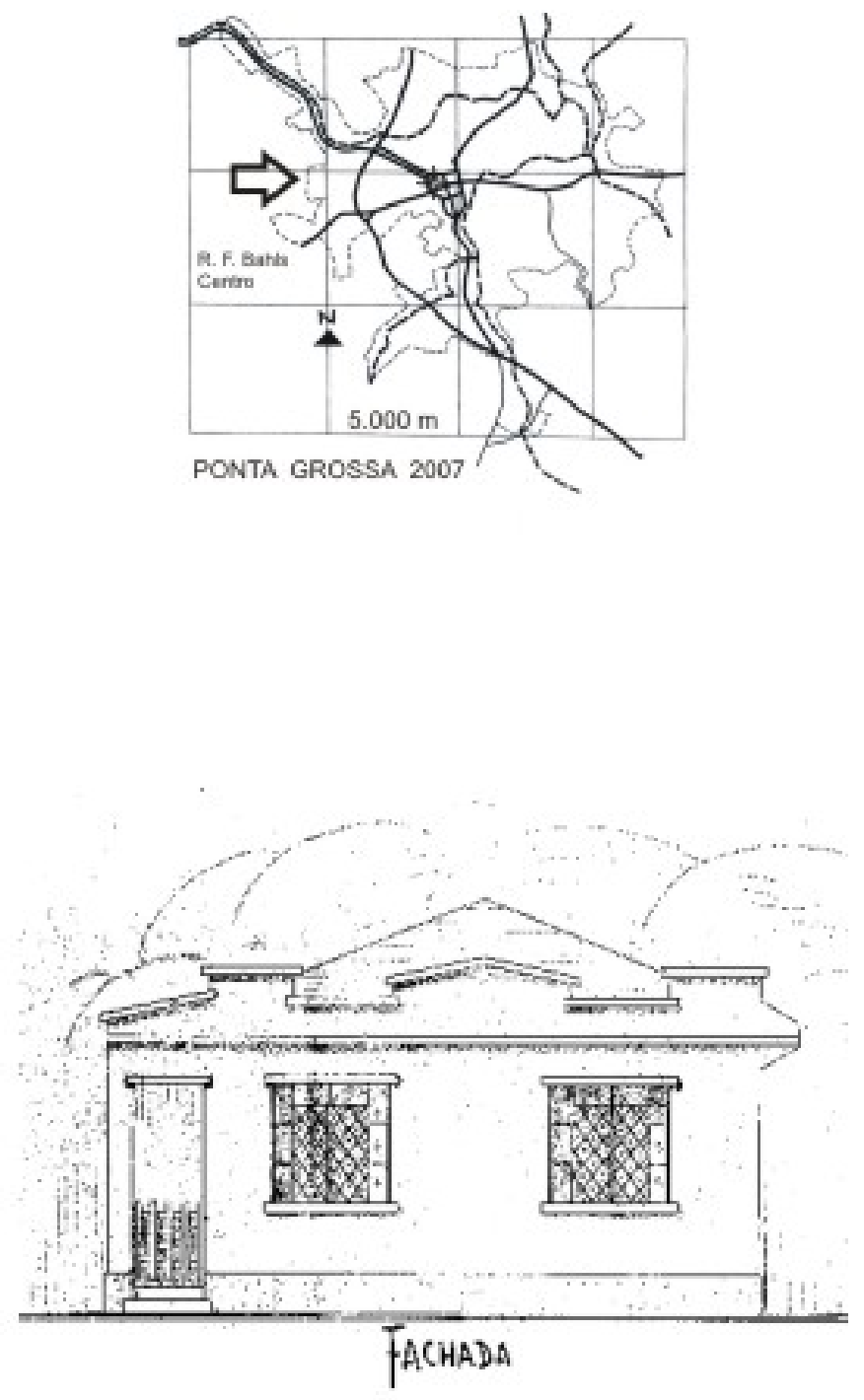

F012/54

Casa de madeira mista

Ano de construção - 1954

Proprietário - Antonio Batista

Uso residencial

Fonte: prefeitura/2006 

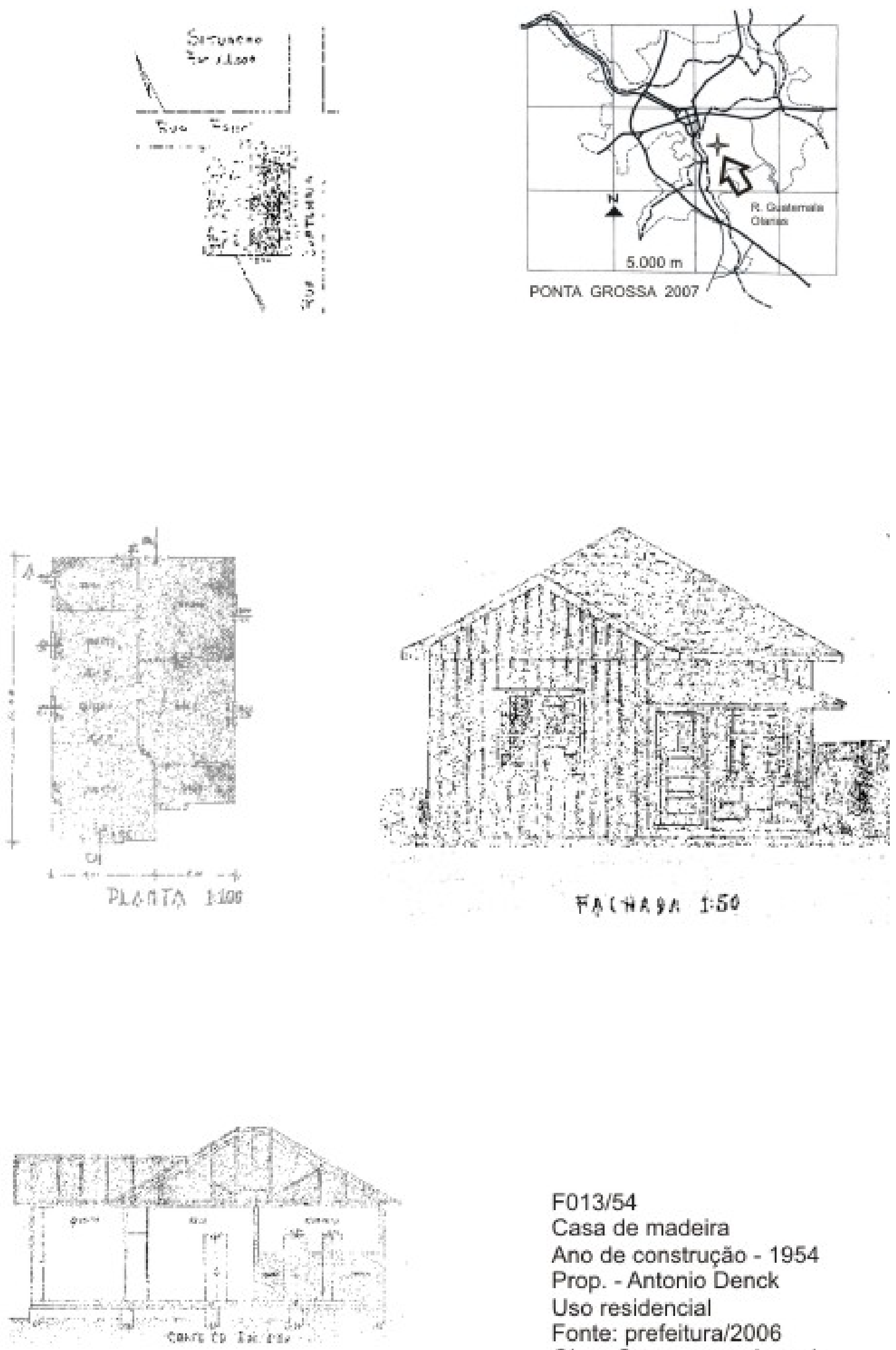

F013/54

Casa de madeira

Ano de construção - 1954

Prop. - Antonio Denck

Uso residencial

Fonte: prefeitura/2006

Obs.- Casas para aluguel 

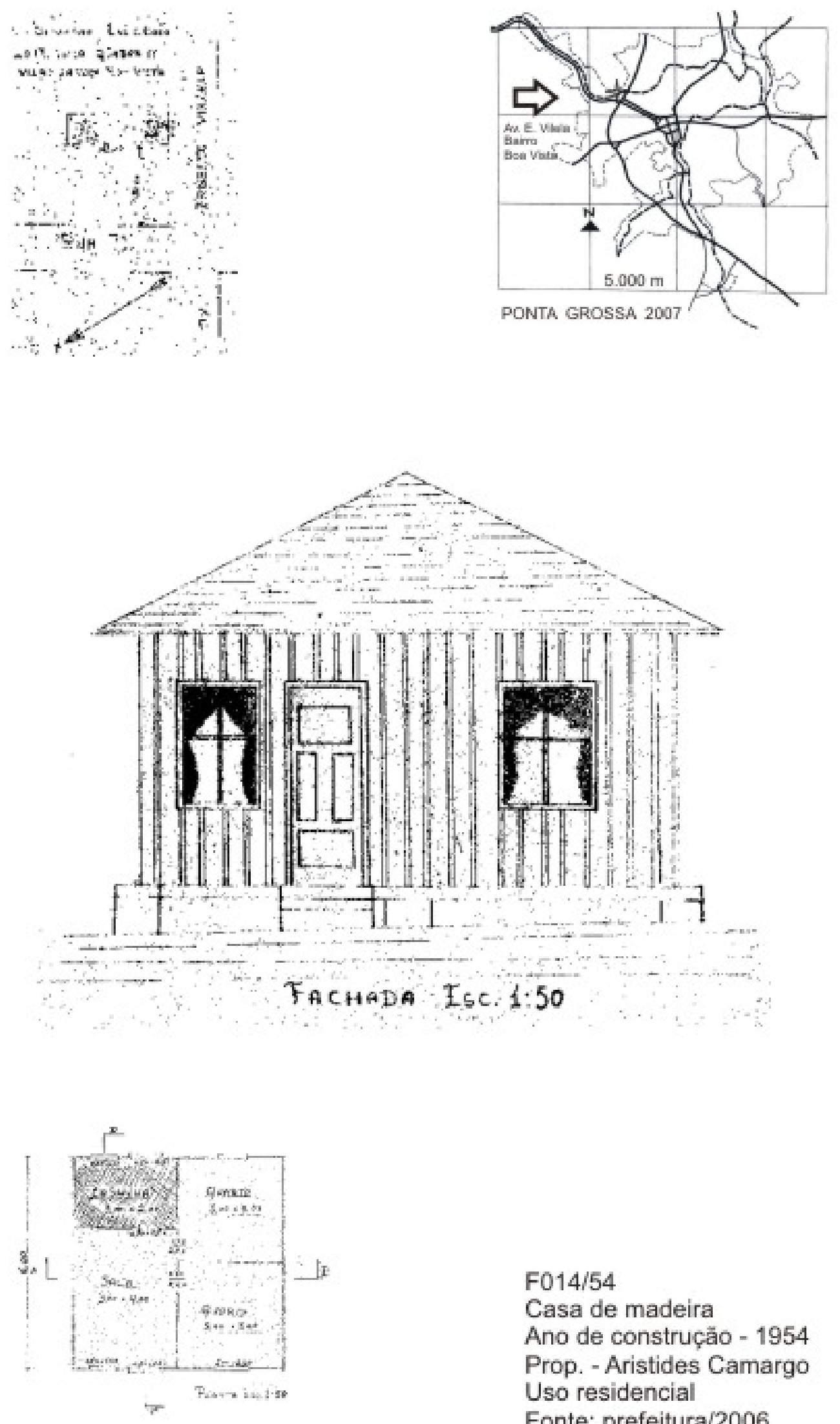

F014/54

Casa de madeira

Ano de construçăo - 1954

Prop. - Aristides Camargo

Uso residencial

Fonte: prefeitura/2006 

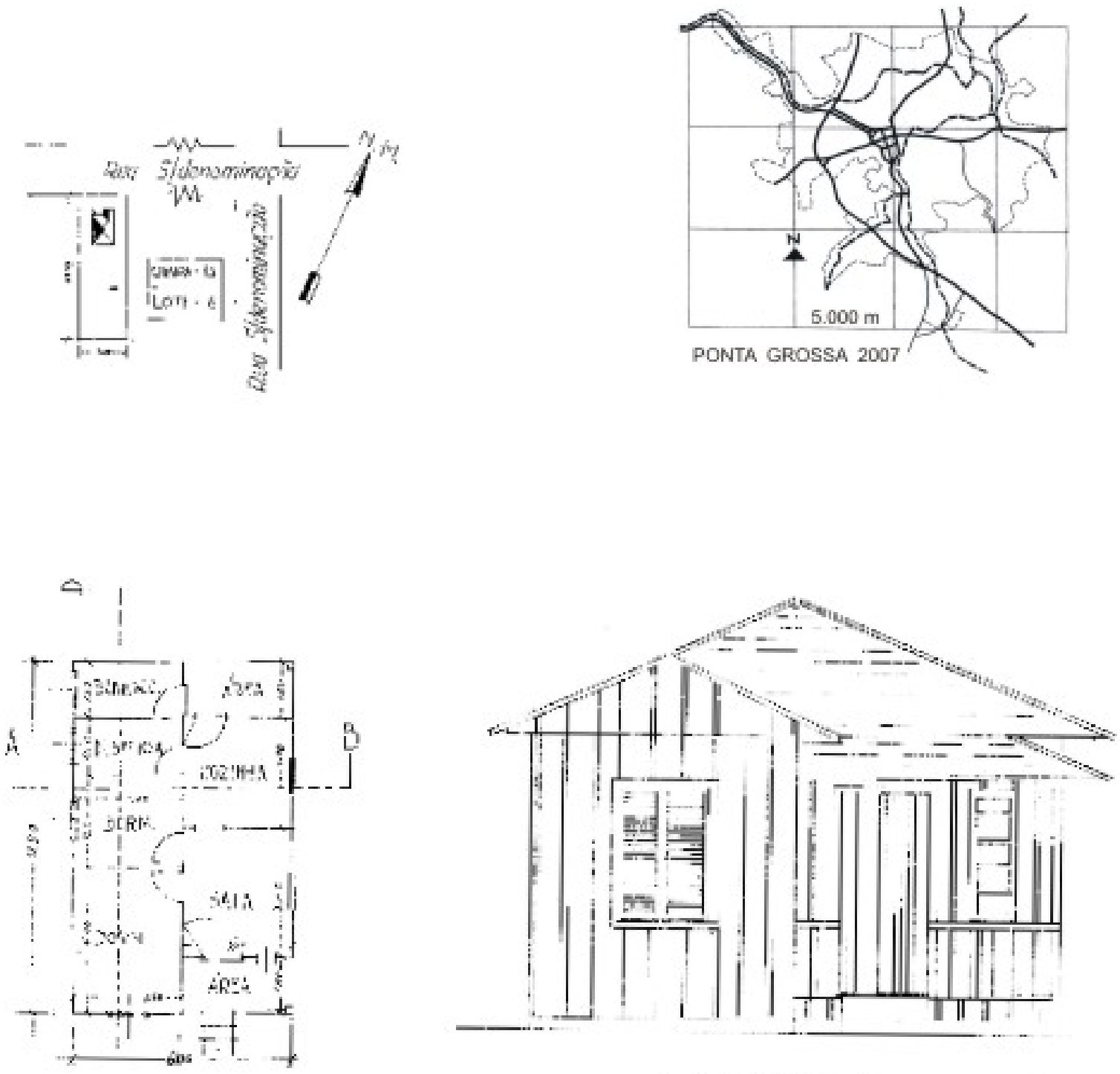

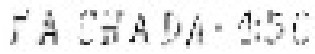

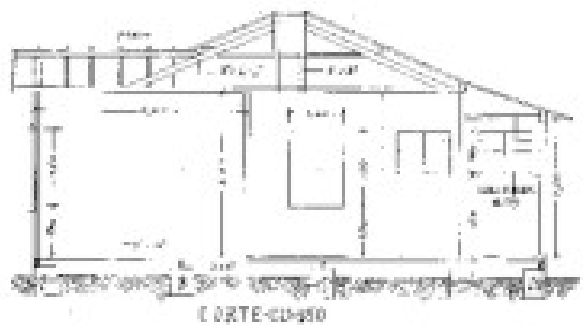

F015/54

Casa de madeira

Ano de construçăo - 1954

Proprietário - Carlos Baniski

Uso residencial

Fonte: prefeitura/2006 

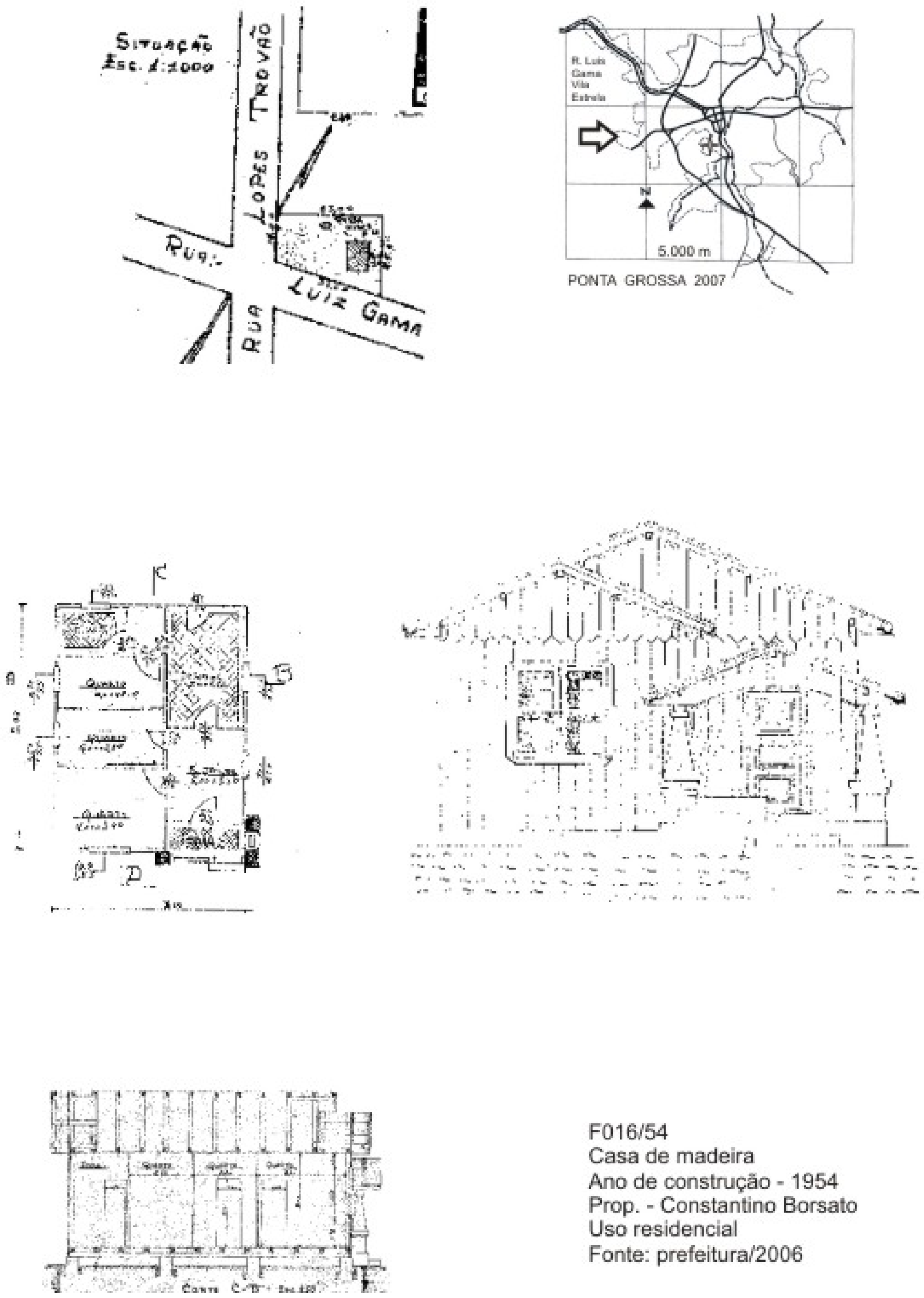

F016/54

Casa de madeira

Ano de construção - 1954

Prop. - Constantino Borsato

Uso residencial

Fonte: prefeitura/2006 

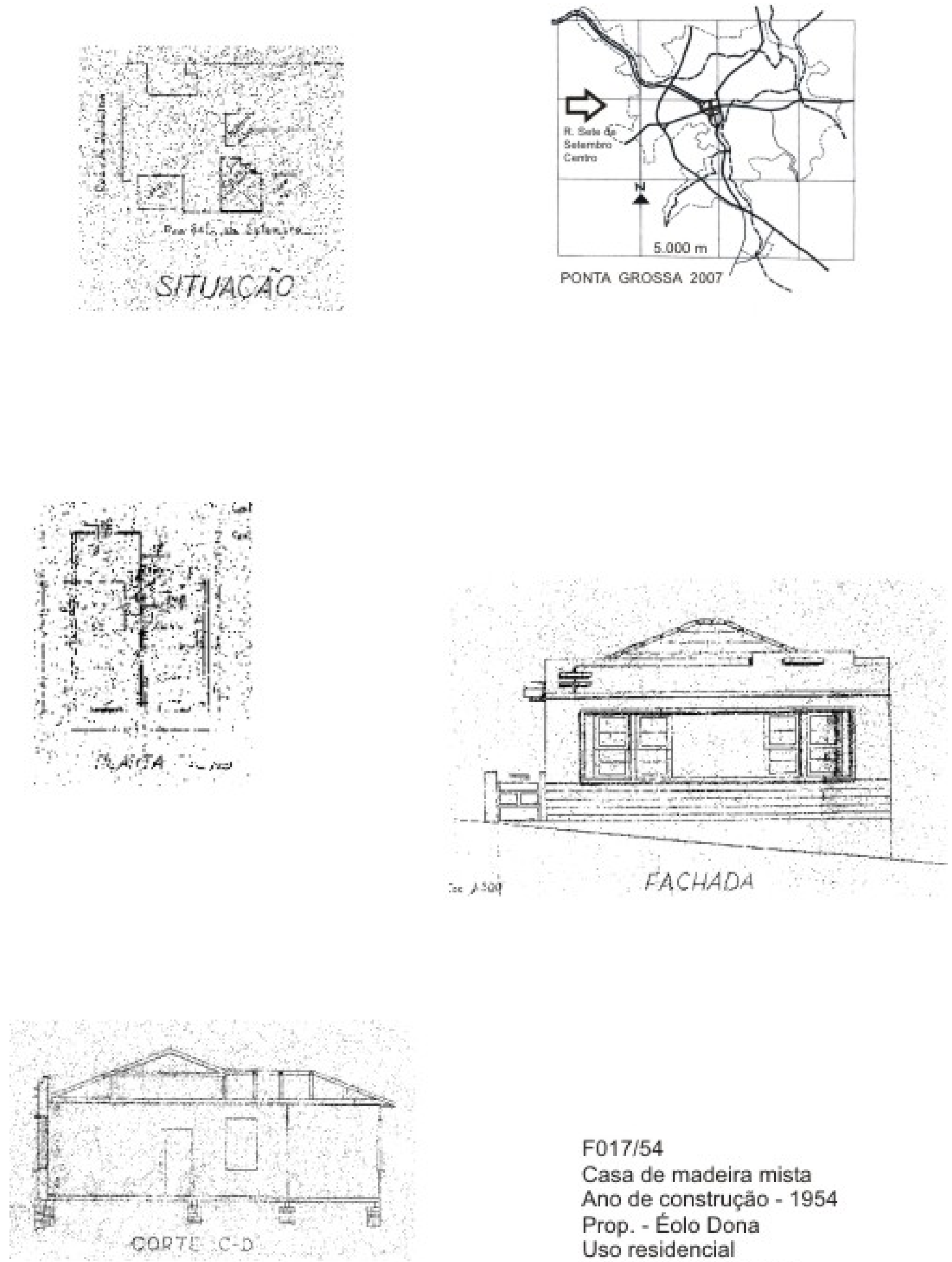

F017/54

Casa de madeira mista Ano de construção - 1954 Prop. - Eolo Dona Uso residencial Fonte: prefeitura/2006 Obs. - fachada eclética 

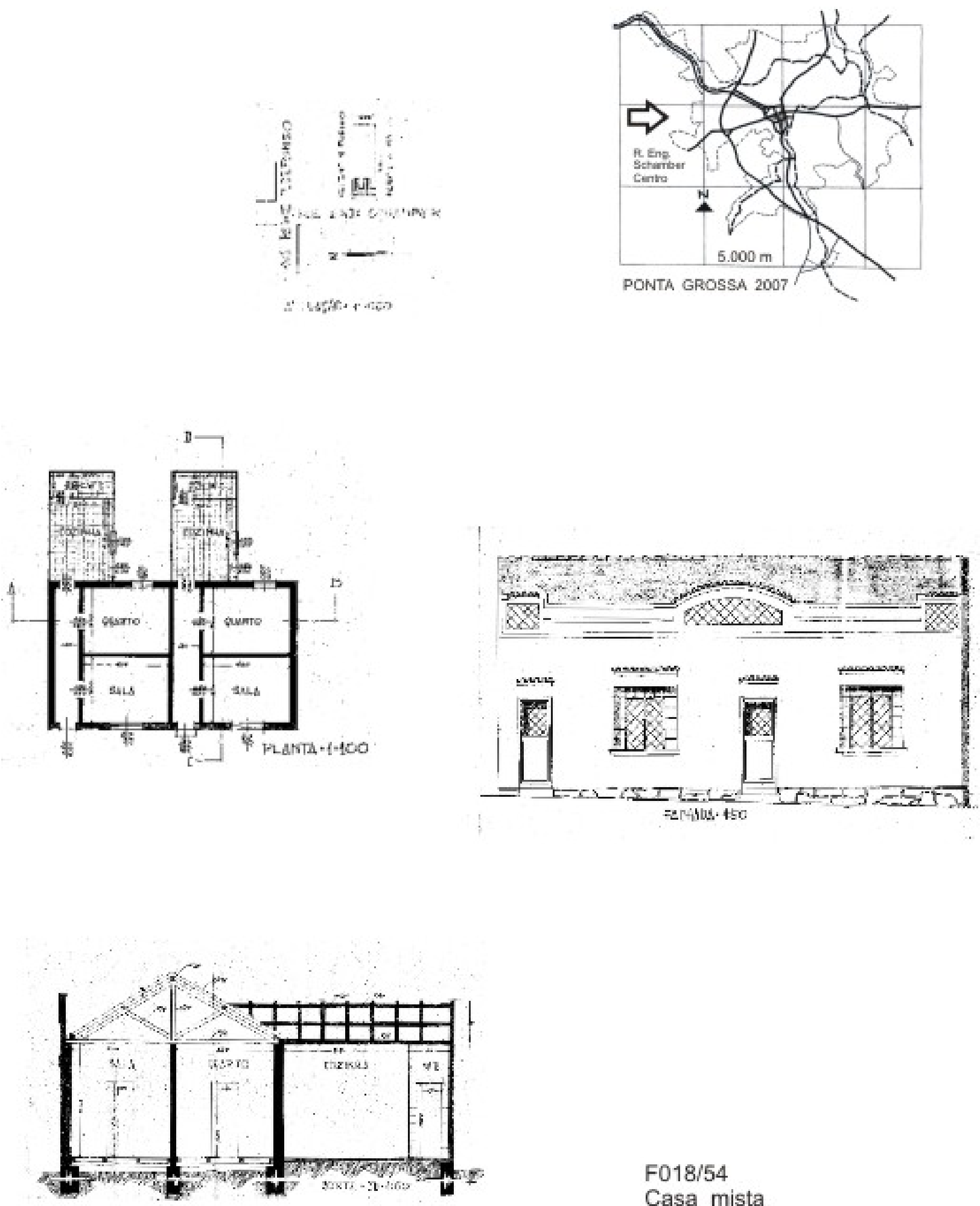

F018/54

Casa mista

Ano de construção - 1954

Prop. - Floresval Justus

Uso residencial

Fonte: prefeitura/2006

Obs. - planta geminada 

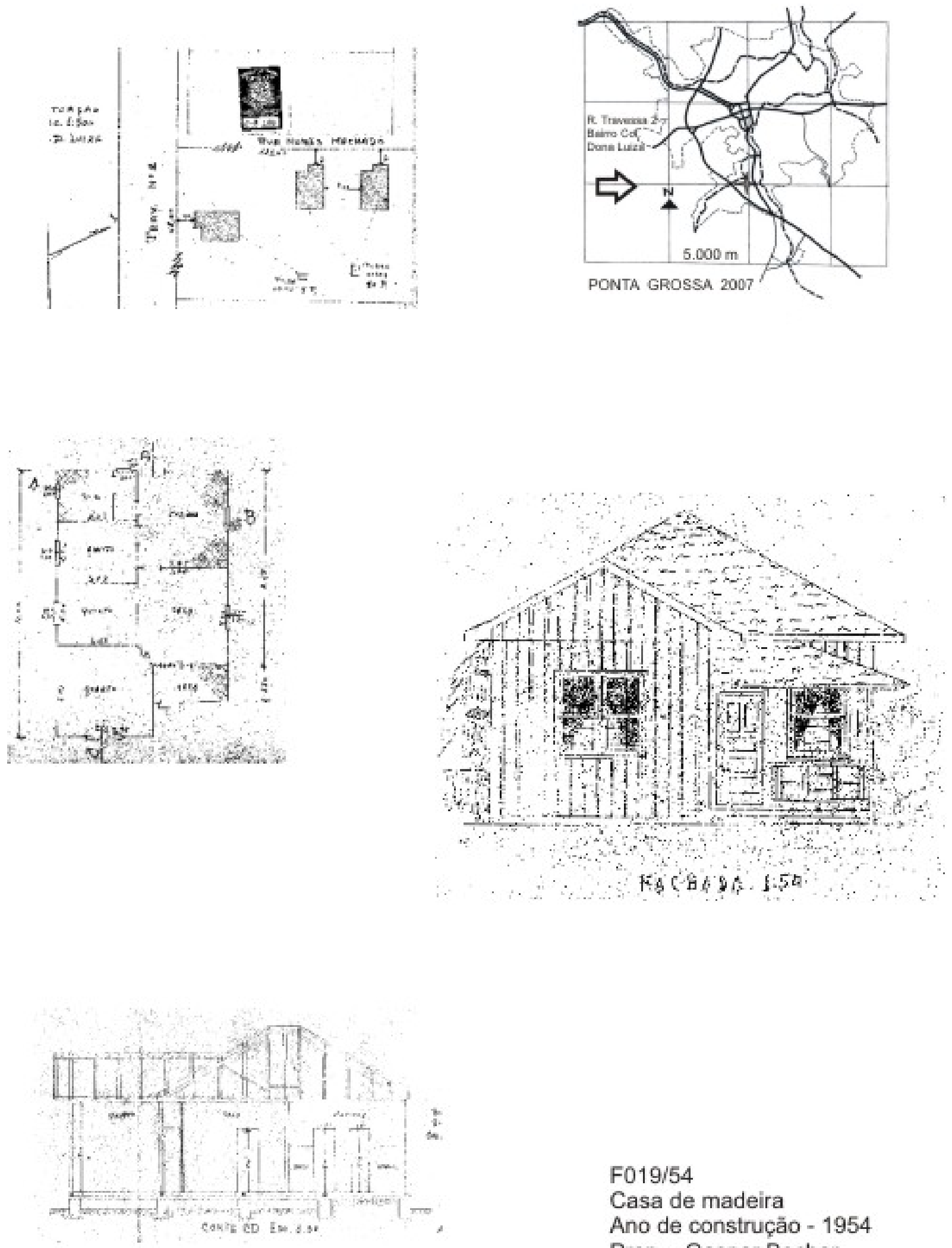

F019/54

Casa de madeira

Ano de construção - 1954

Prop. - Gaspar Becher

Uso residencial

Fonte: prefeitura/2006 

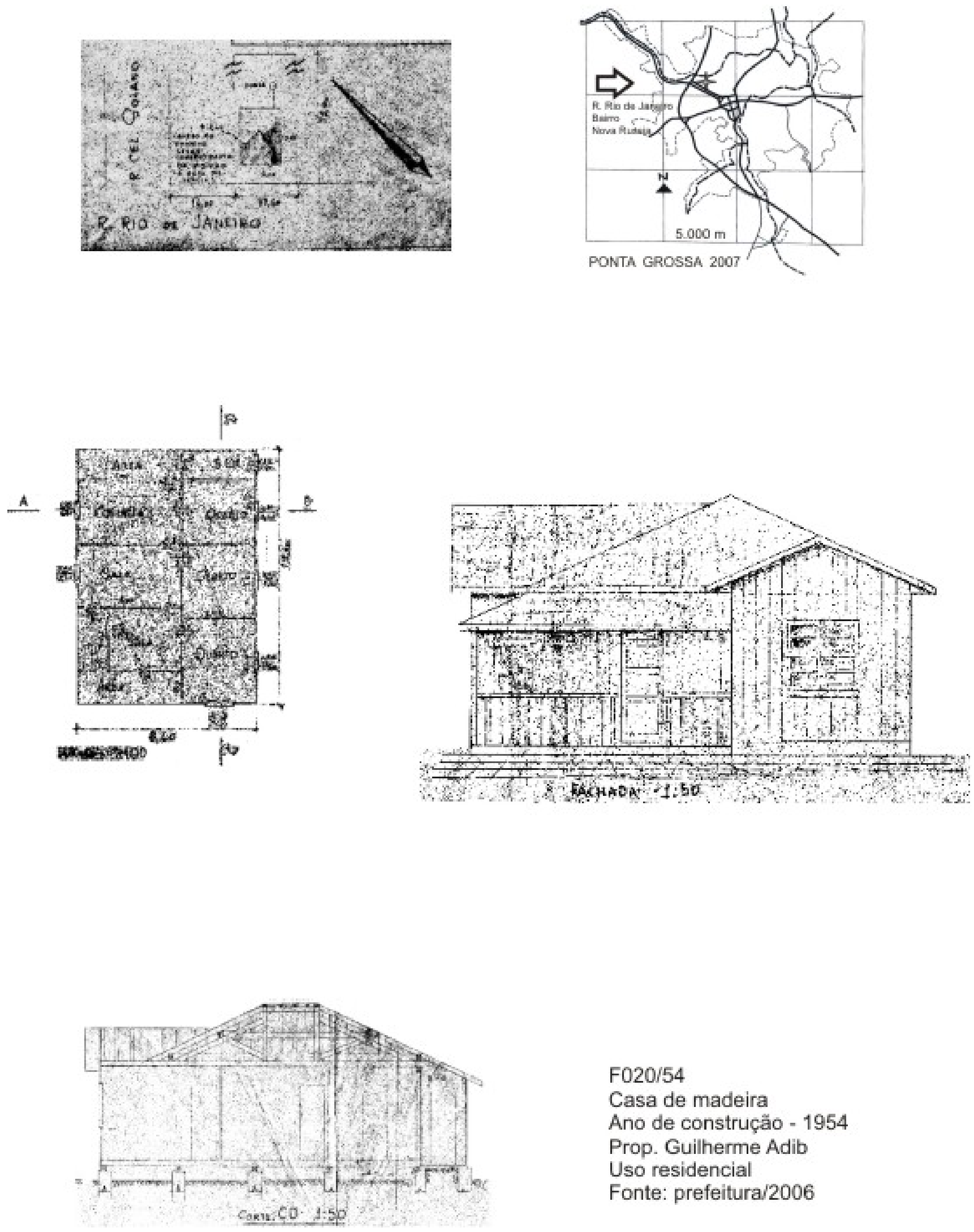

F020/54

Casa de madeira

Ano de construção - 1954

Prop. Guilherme Adib

Uso residencial

Fonte: prefeitura/2006 

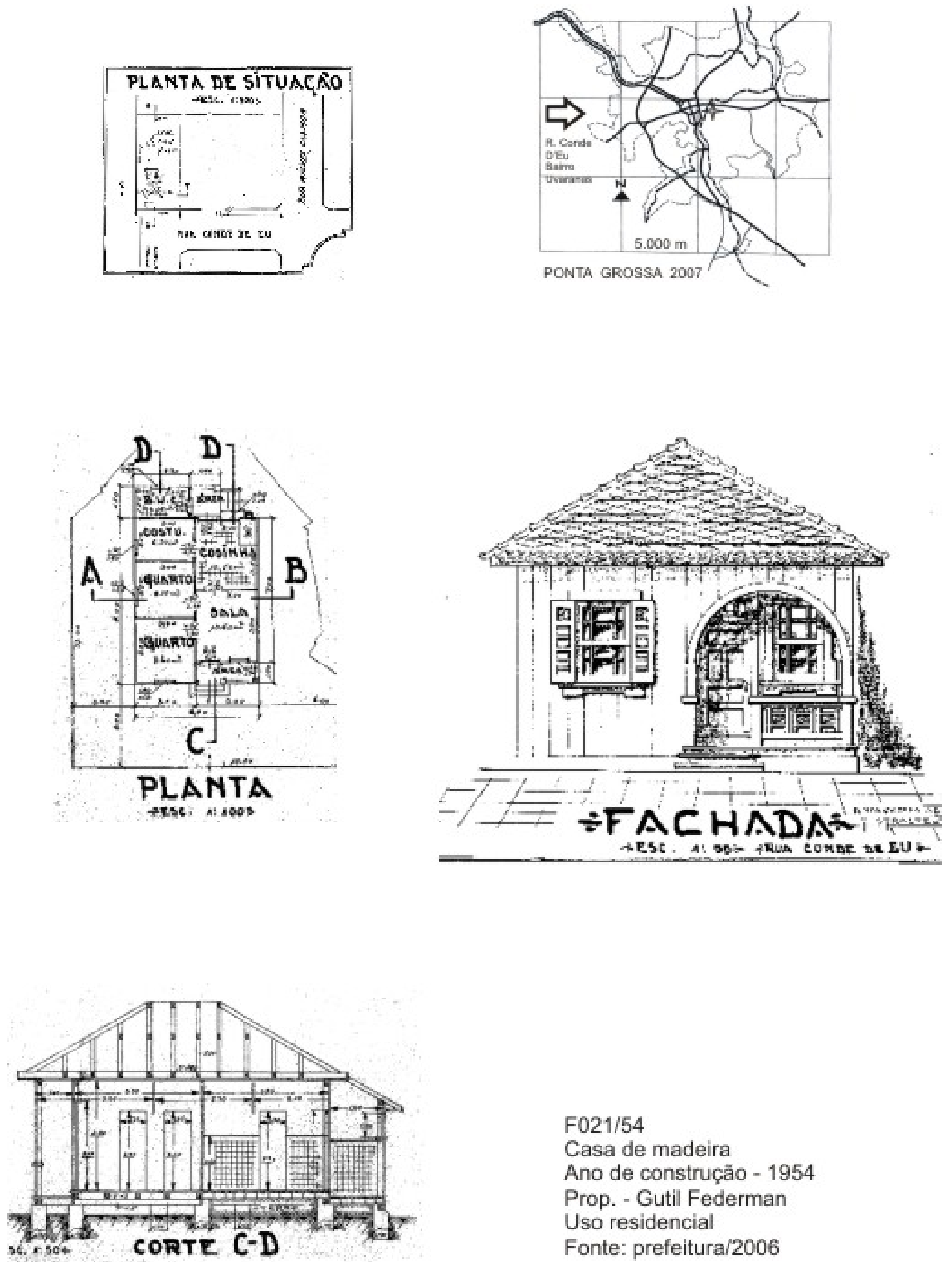

F021/54

Casa de madeira

Ano de construção - 1954

Prop. - Gutil Federman

Uso residencial

Fonte: prefeitura/2006 

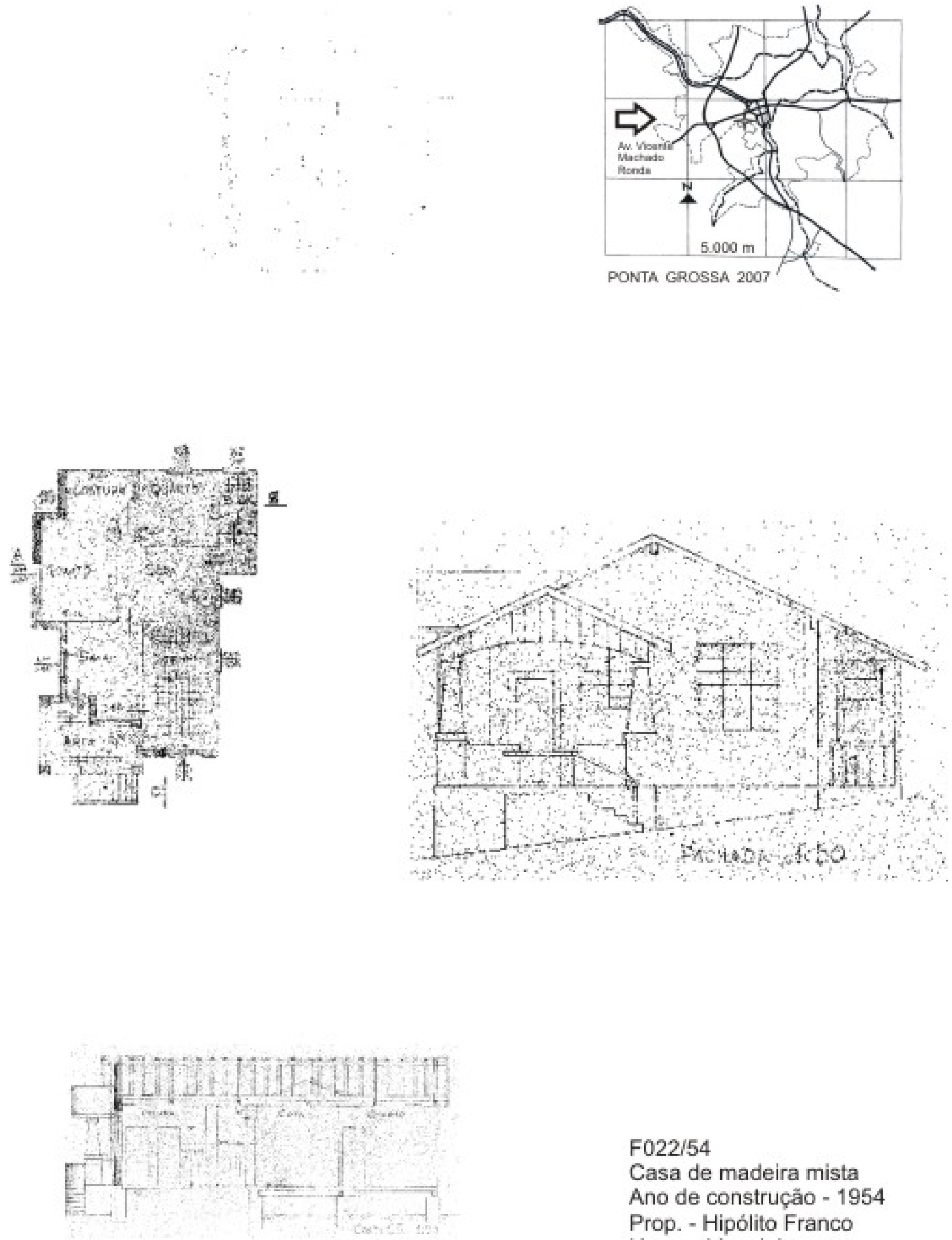

F022/54

Casa de madeira mista

Ano de construçăo - 1954

Prop. - Hipólito Franco Uso residencial

Fonte: prefeitura/2006 

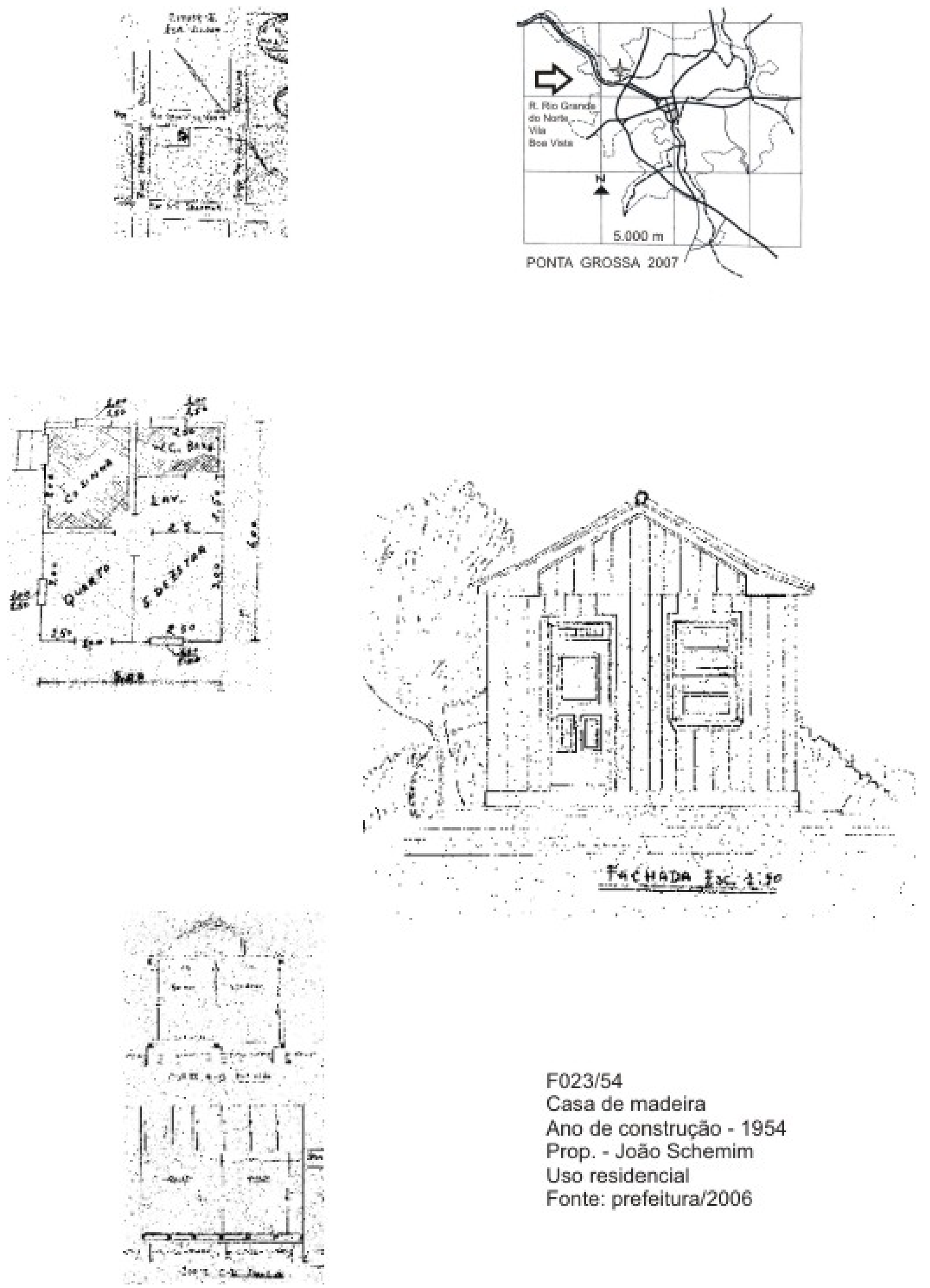

F023/54

Casa de madeira

Ano de construçăo - 1954

Prop. - Joăo Schemim

Uso residencial

Fonte: prefeitura/2006 

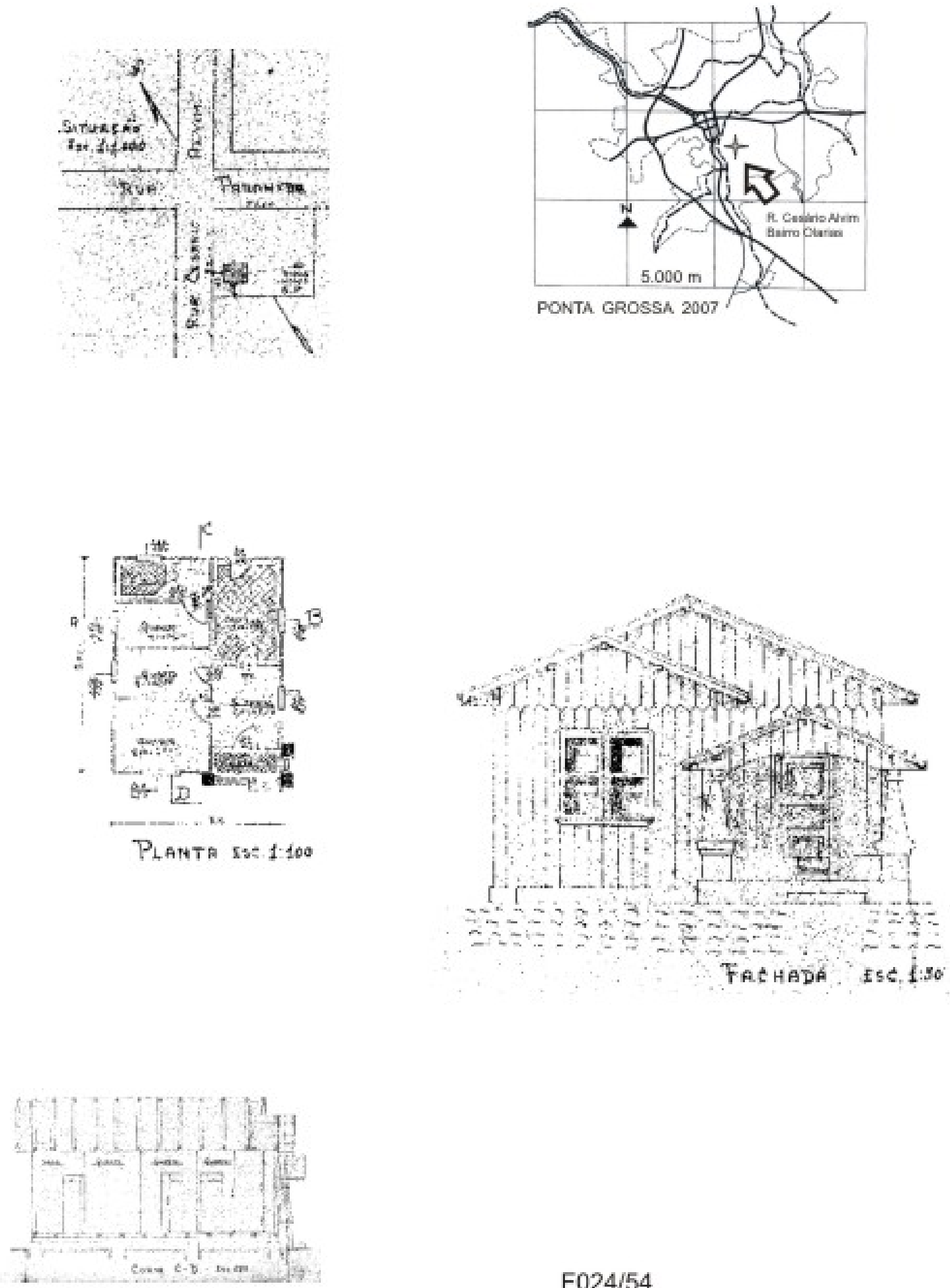

F024/54

Casa de madeira

Ano de construção - 1954

Prop. - Joaquim Alves Neto

Uso residencial

Fonte: prefeitura/2006

Obs. - típico bangalô 

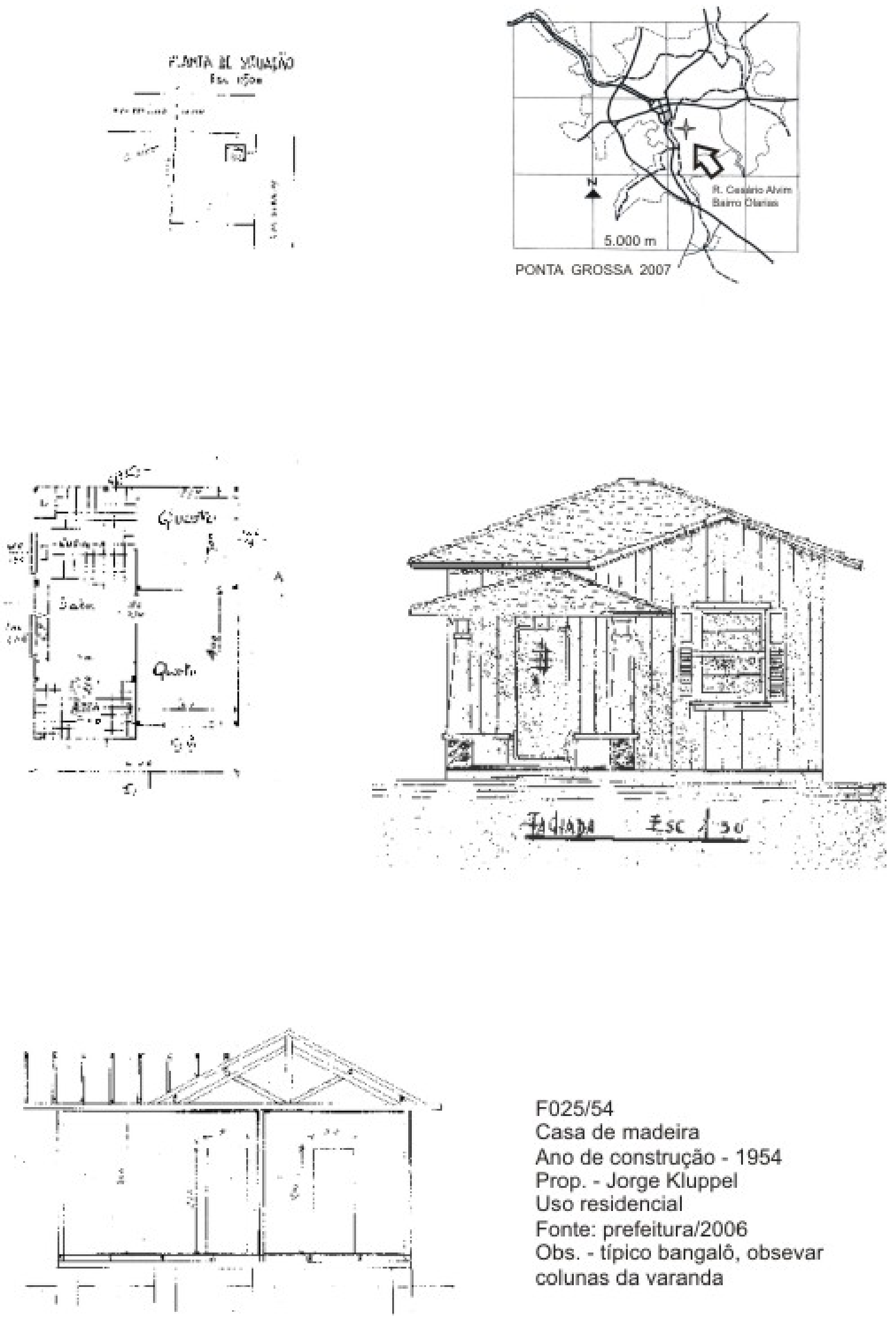

F025/54

Casa de madeira

Ano de construção - 1954

Prop. - Jorge Kluppel

Uso residencial

Fonte: prefeitura/2006

Obs. - típico bangalô, obsevar

colunas da varanda 

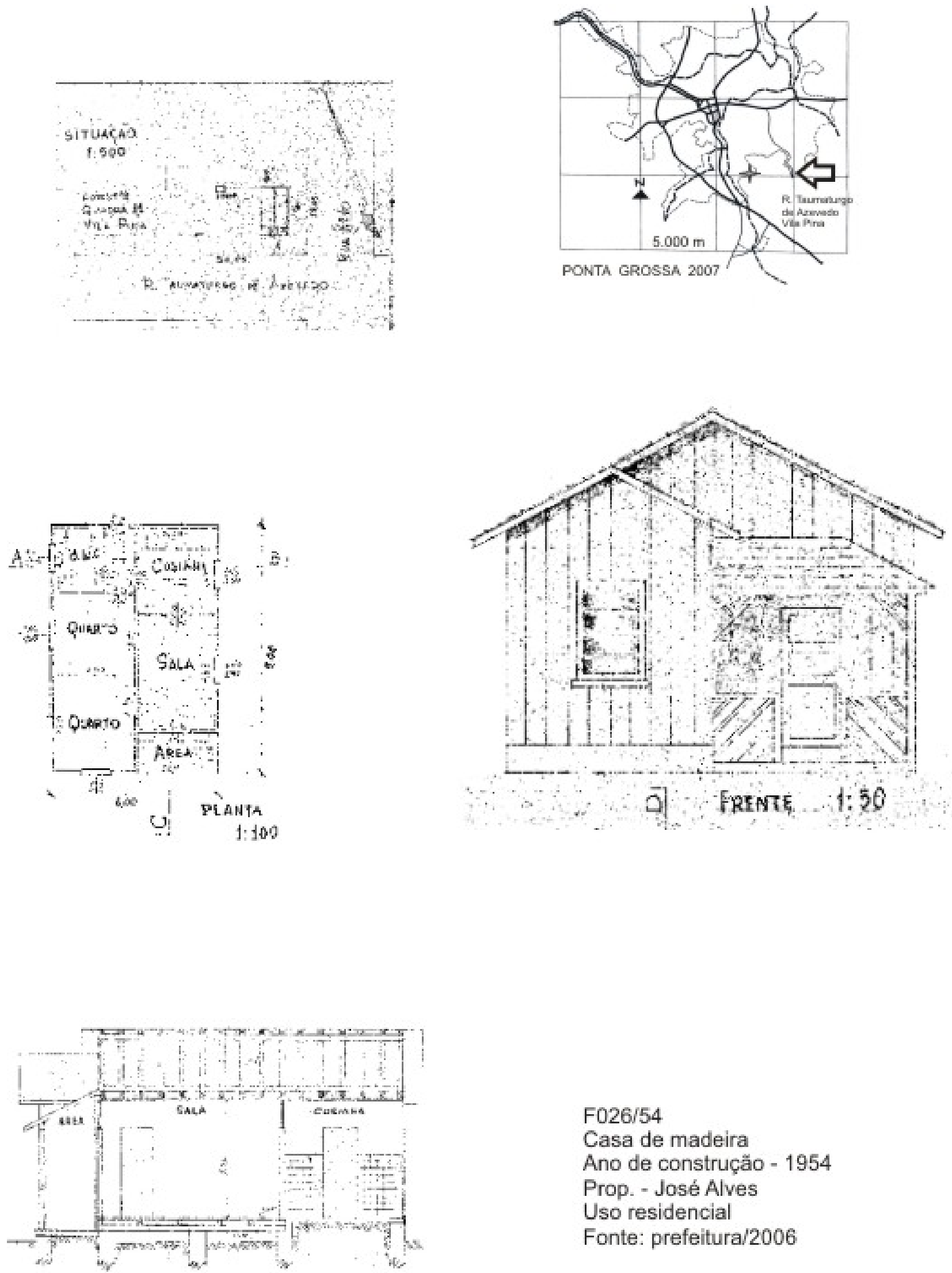

$\mathrm{F} 026 / 54$

Casa de madeira

Ano de construção - 1954

Prop. - José Alves

Uso residencial

Fonte: prefeitura/2006 

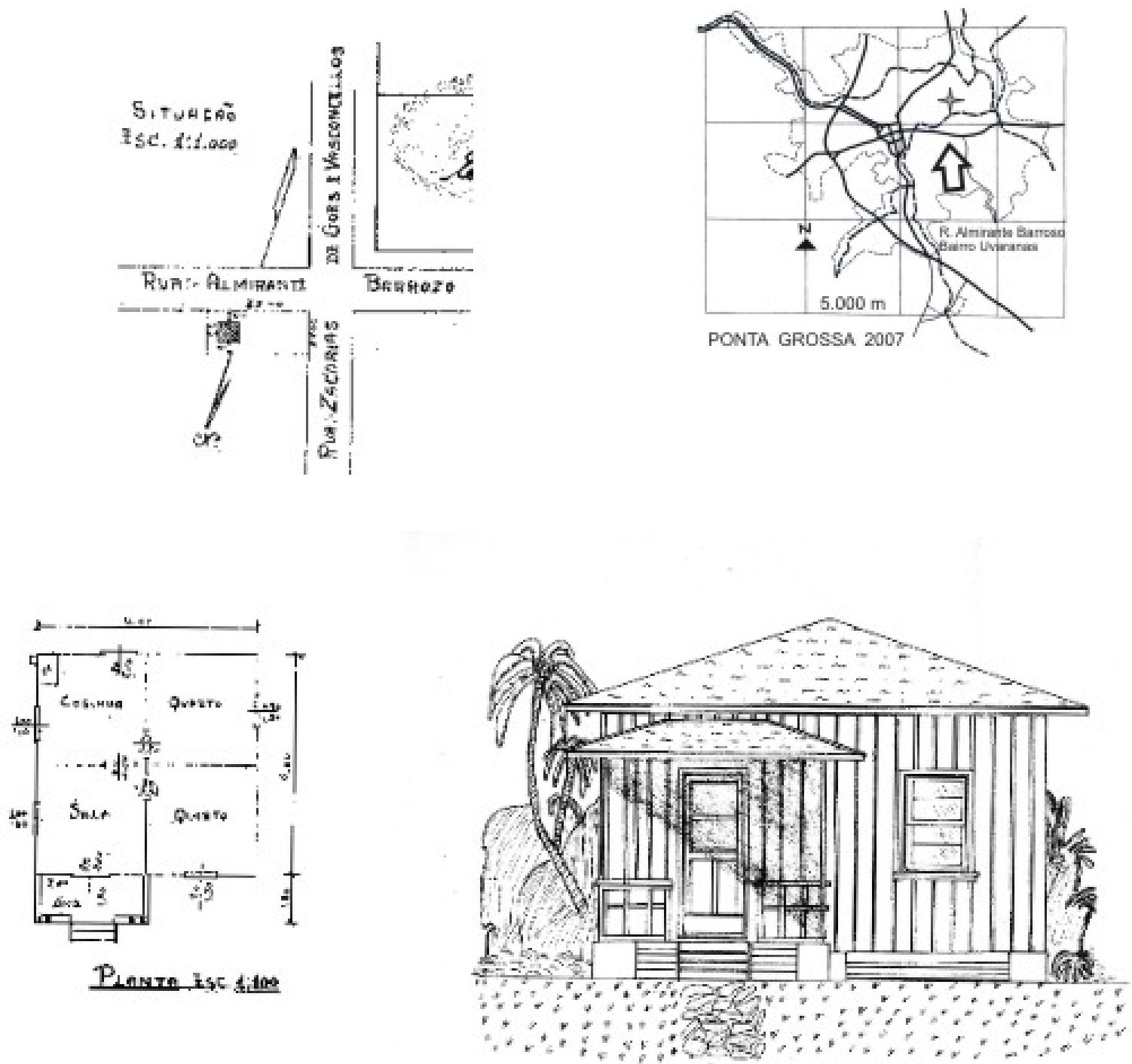

FACHADA IDC. 1:50

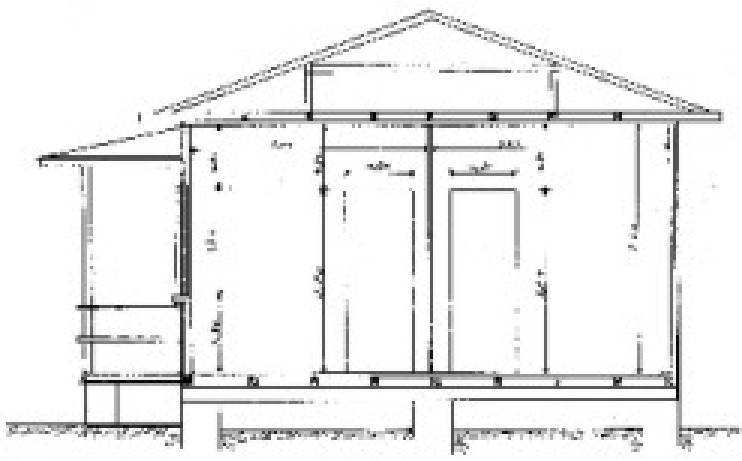

\section{F027/54}

Casa de madeira

Ano de construção - 1954

Prop. - José Binder

Uso residencial

Fonte: prefeitura/2006 

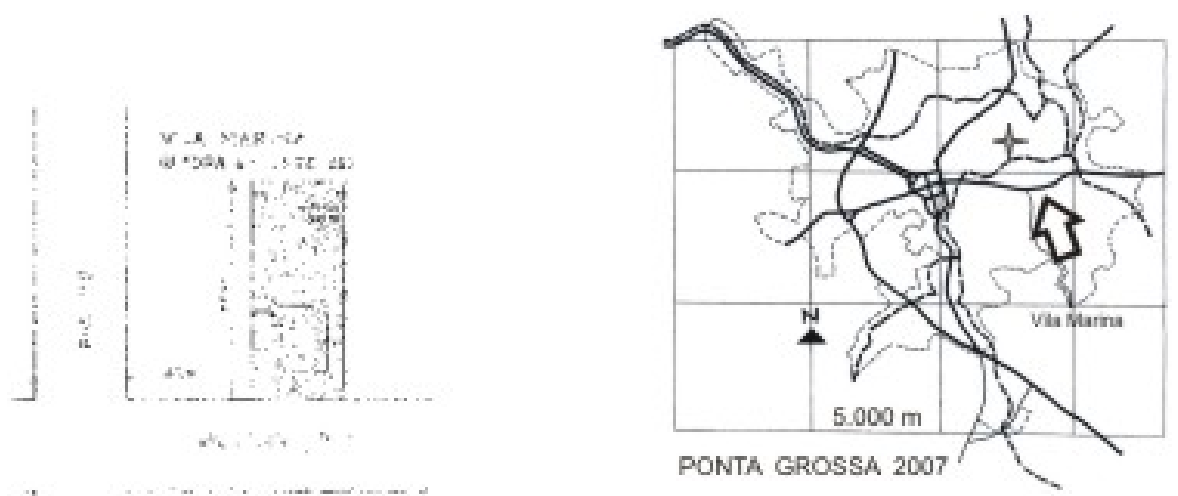

PLANTA DE STIJACX̃O
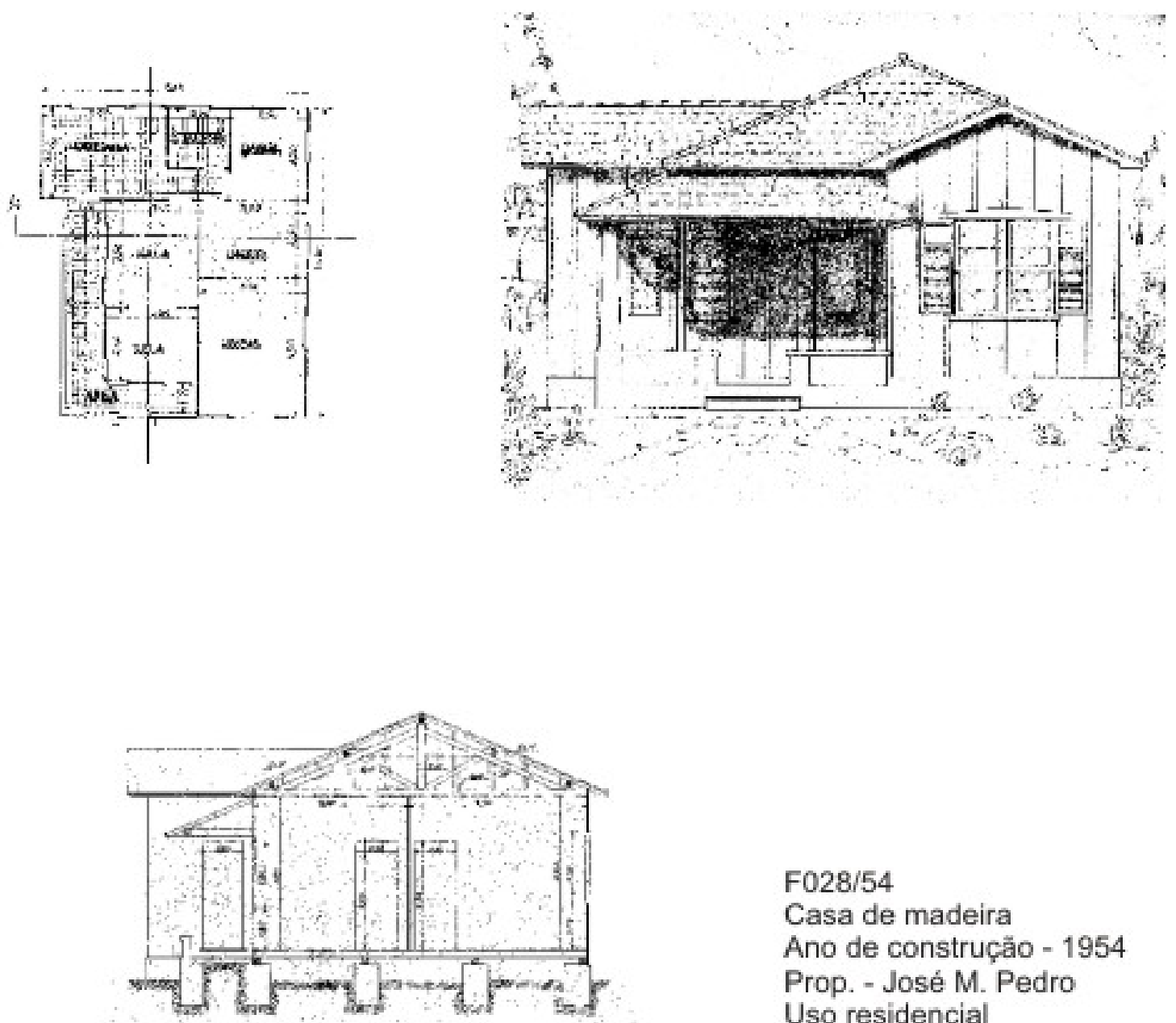

$\mathrm{F} 028 / 54$

Casa de madeira

Ano de construçăo - 1954

Prop. - José M. Pedro

Uso residencial

Fonte: prefeitura/2006

Obs. - típico bangalô

pontagrossense 

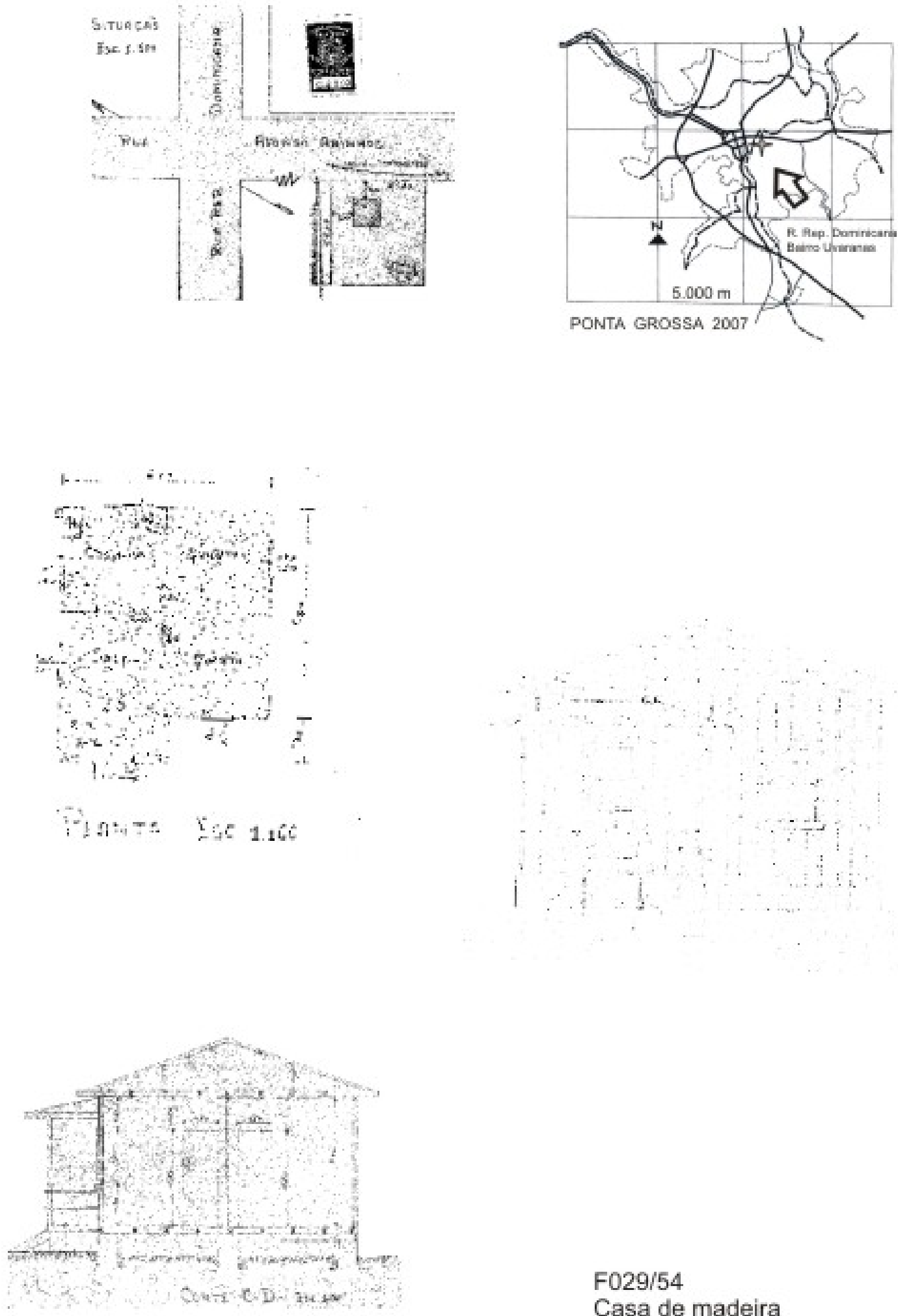

F029/54

Casa de madeira

Ano de construçäo - 1954

Prop. - Josefino de Brito

Uso residencial

Fonte: prefeitura/2006

Obs. - tipico bangalô simples 

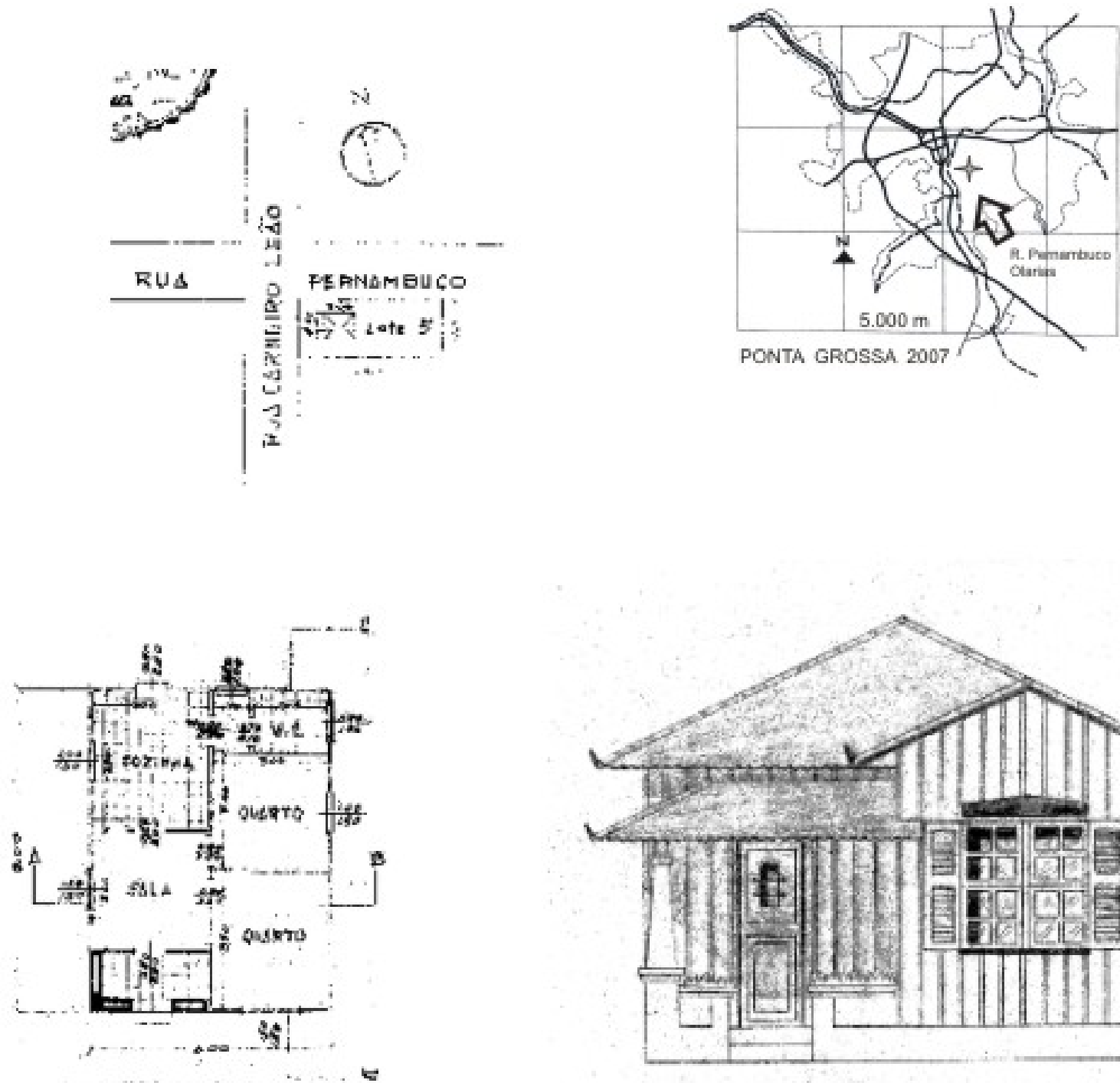

PLANTA - 1:100
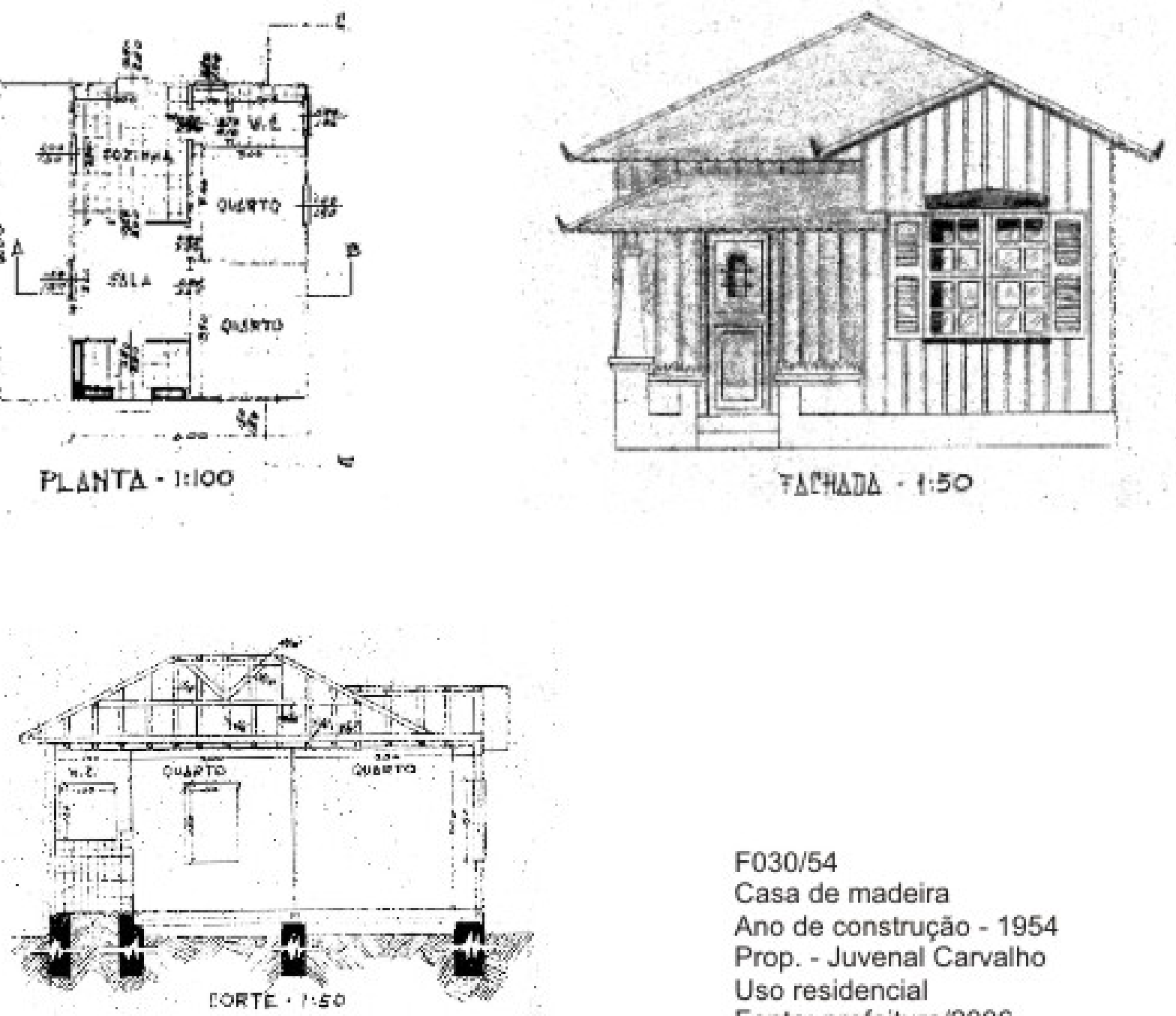

F030/54

Casa de madeira

Ano de construção - 1954

Prop. - Juvenal Carvalho

Uso residencial

Fonte: prefeitura/2006

Obs. - típico bangalô urbano 

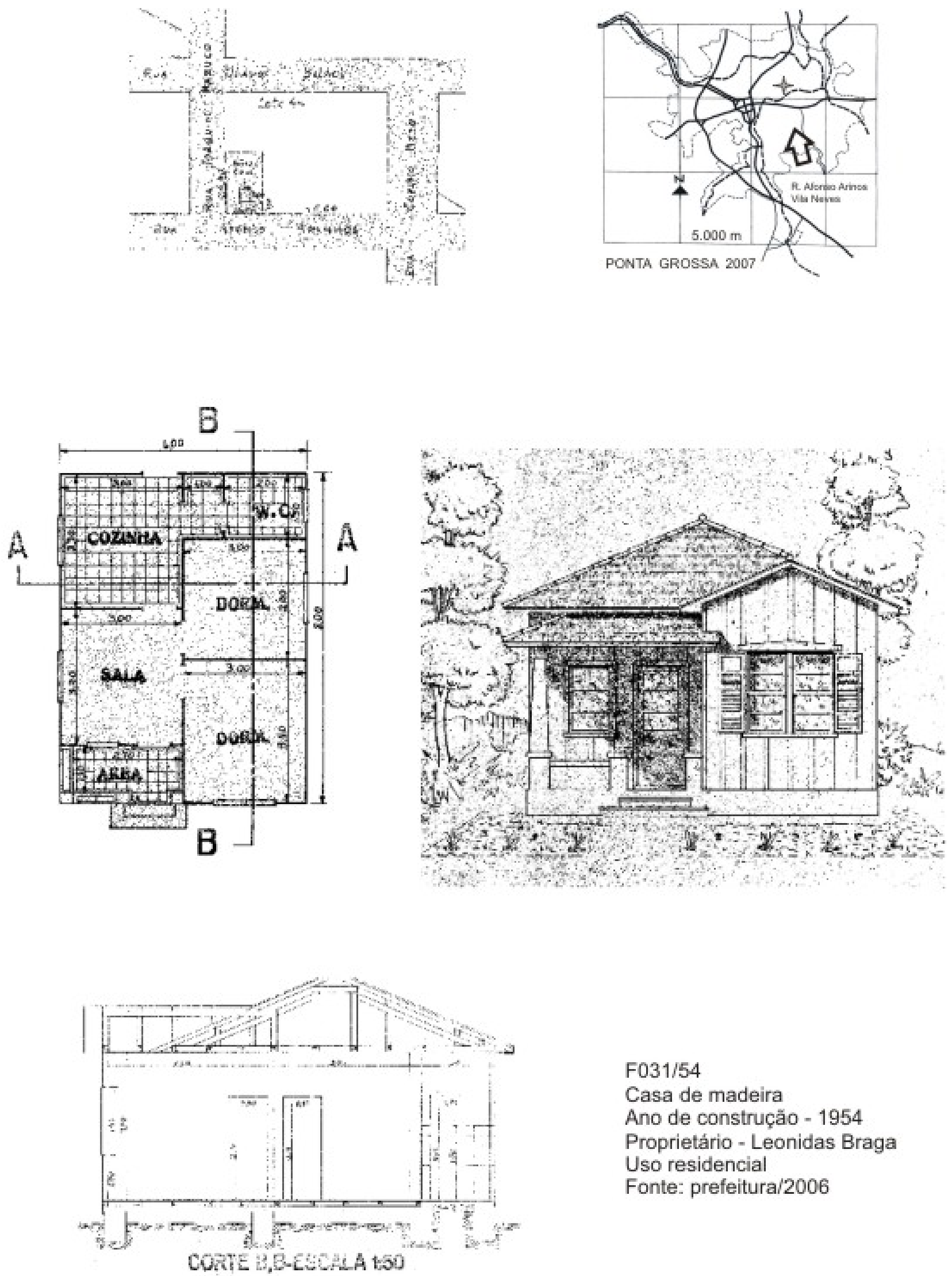

F031/54

Casa de madeira

Ano de construção - 1954

Proprietário - Leonidas Braga Uso residencial

Fonte: prefeitura/2006 

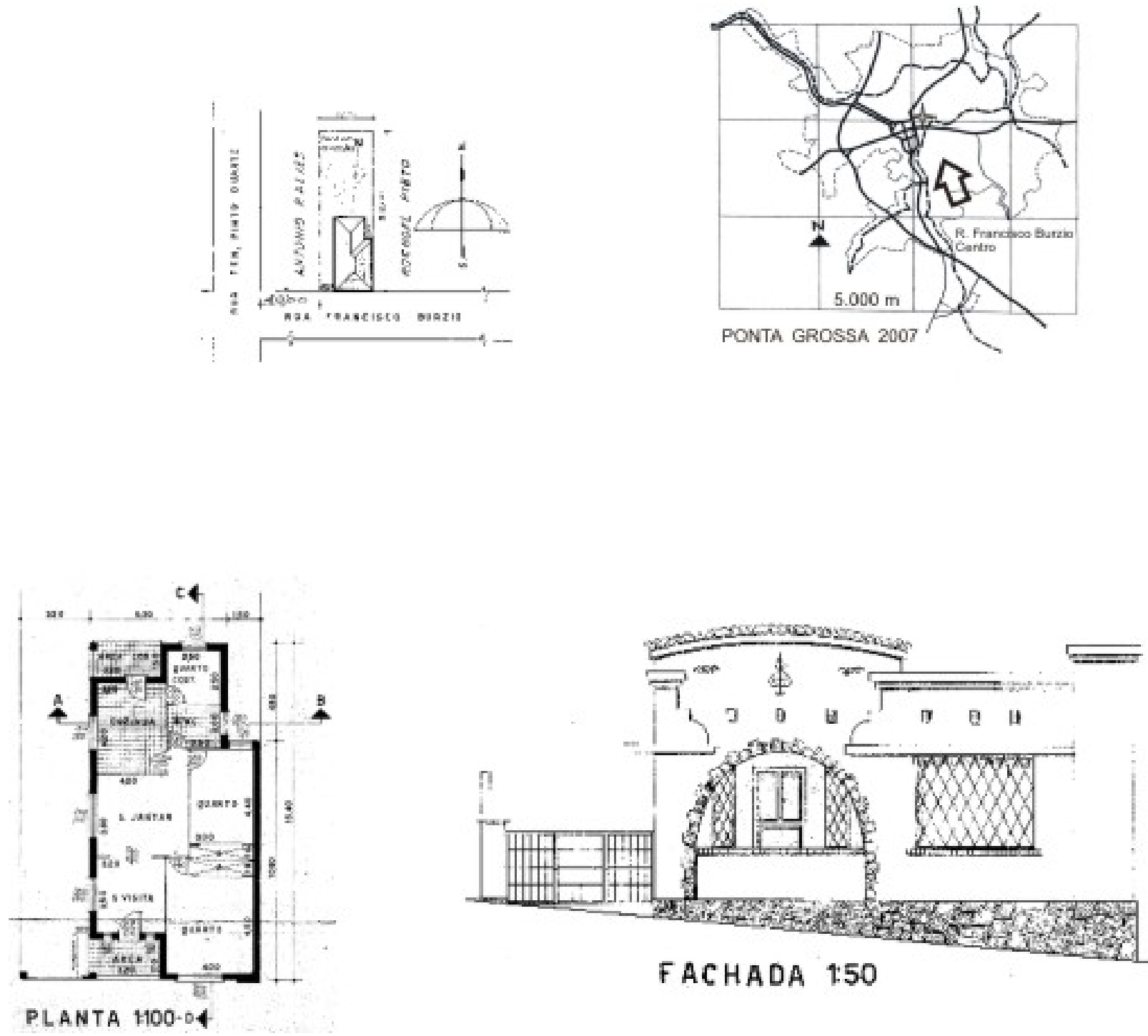

FACHADA $1: 50$

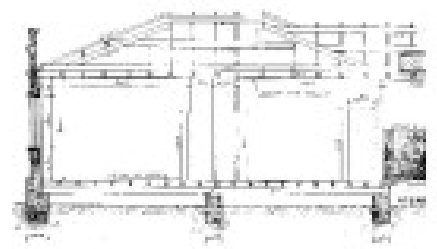

F032/54

Casa de madeira mista Ano de construçăo - 1954

Prop. - Manoel S. Bahls Uso residencial

Fonte: prefeitura/2006

Obs.- Fachada neocolonial 

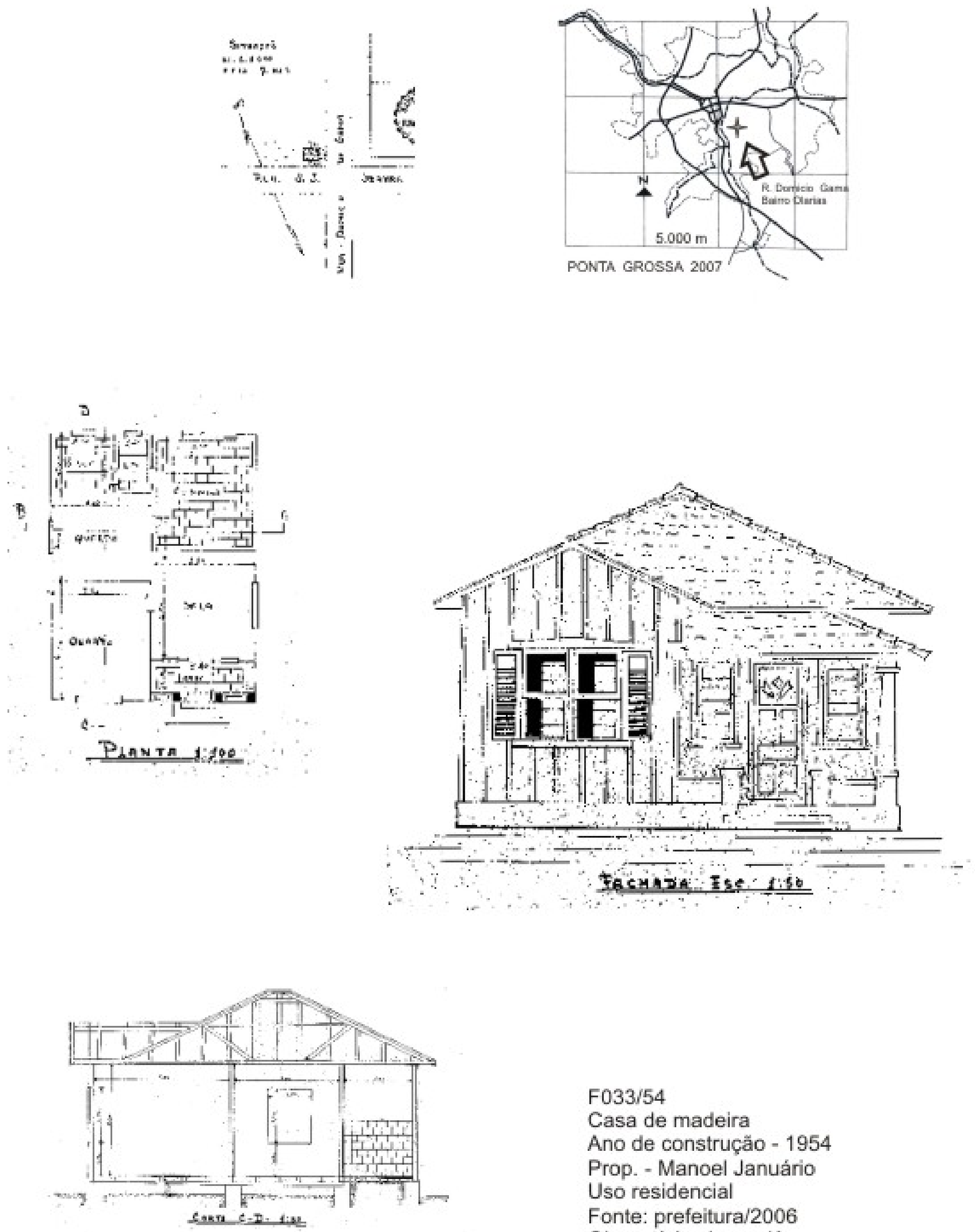

F033/54

Casa de madeira

Ano de construçăo - 1954

Prop. - Manoel Januário

Uso residencial

Fonte: prefeitura/2006

Obs. - típico bangalô

pontagrossense 

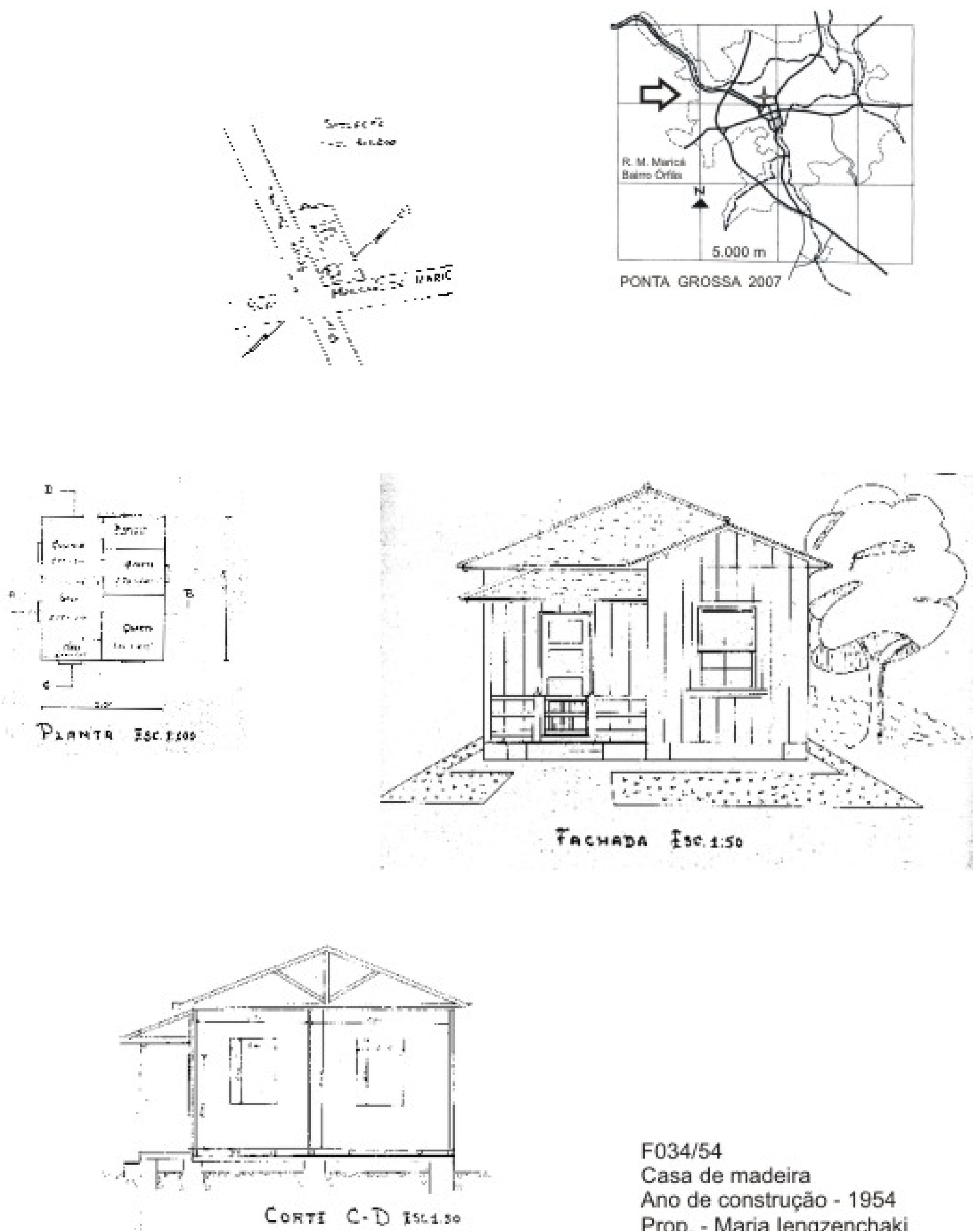

F034/54

Casa de madeira

Ano de construção - 1954

Prop. - Maria lengzenchaki

Uso residencial

Fonte: prefeitura/2006

Obs. - típico bangalô

pontagrossense 

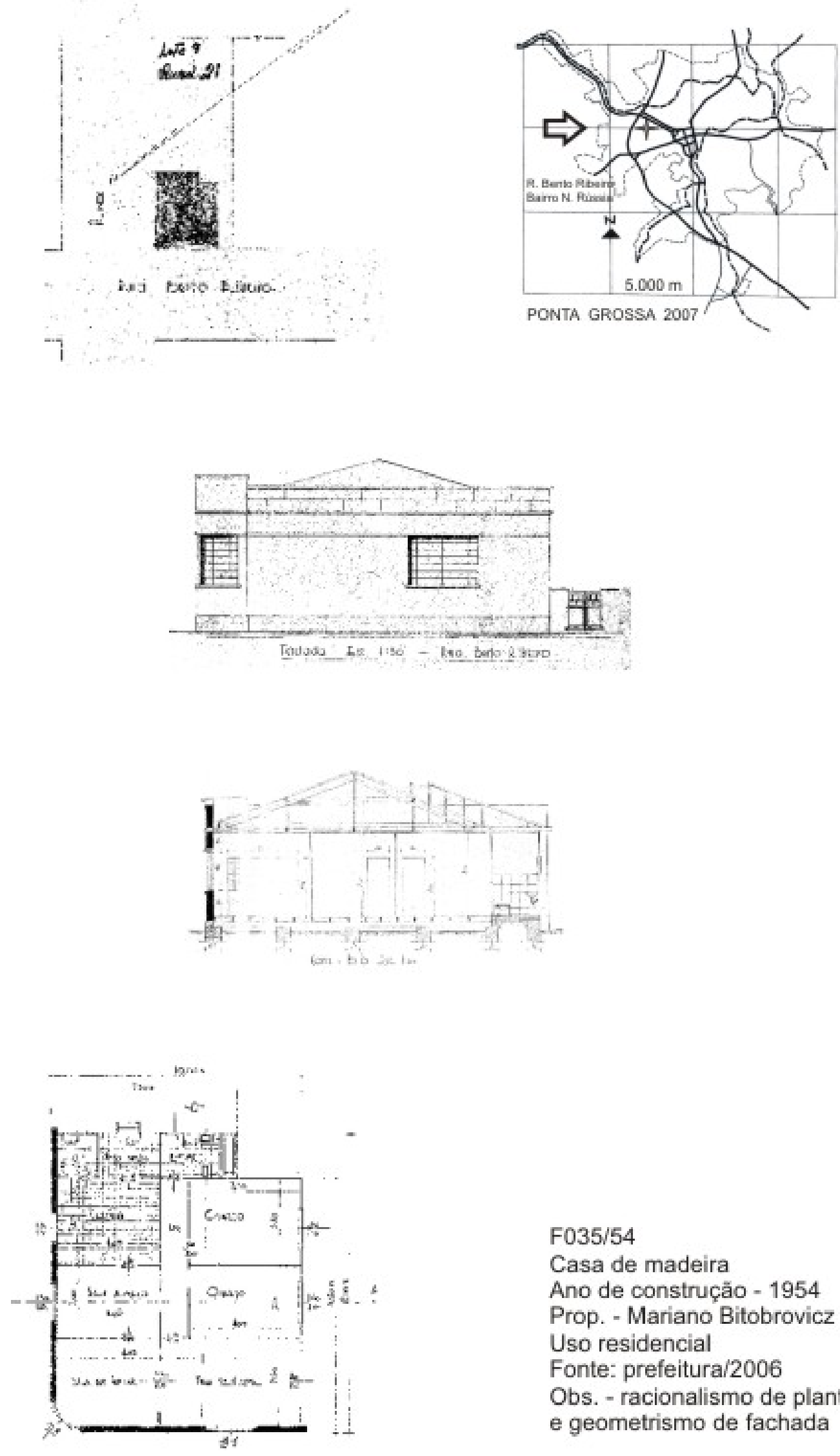

F035/54

Casa de madeira Ano de construção - 1954 Prop. - Mariano Bitobrovicz Uso residencial Fonte: prefeitura/2006 Obs. - racionalismo de planta e geometrismo de fachada 

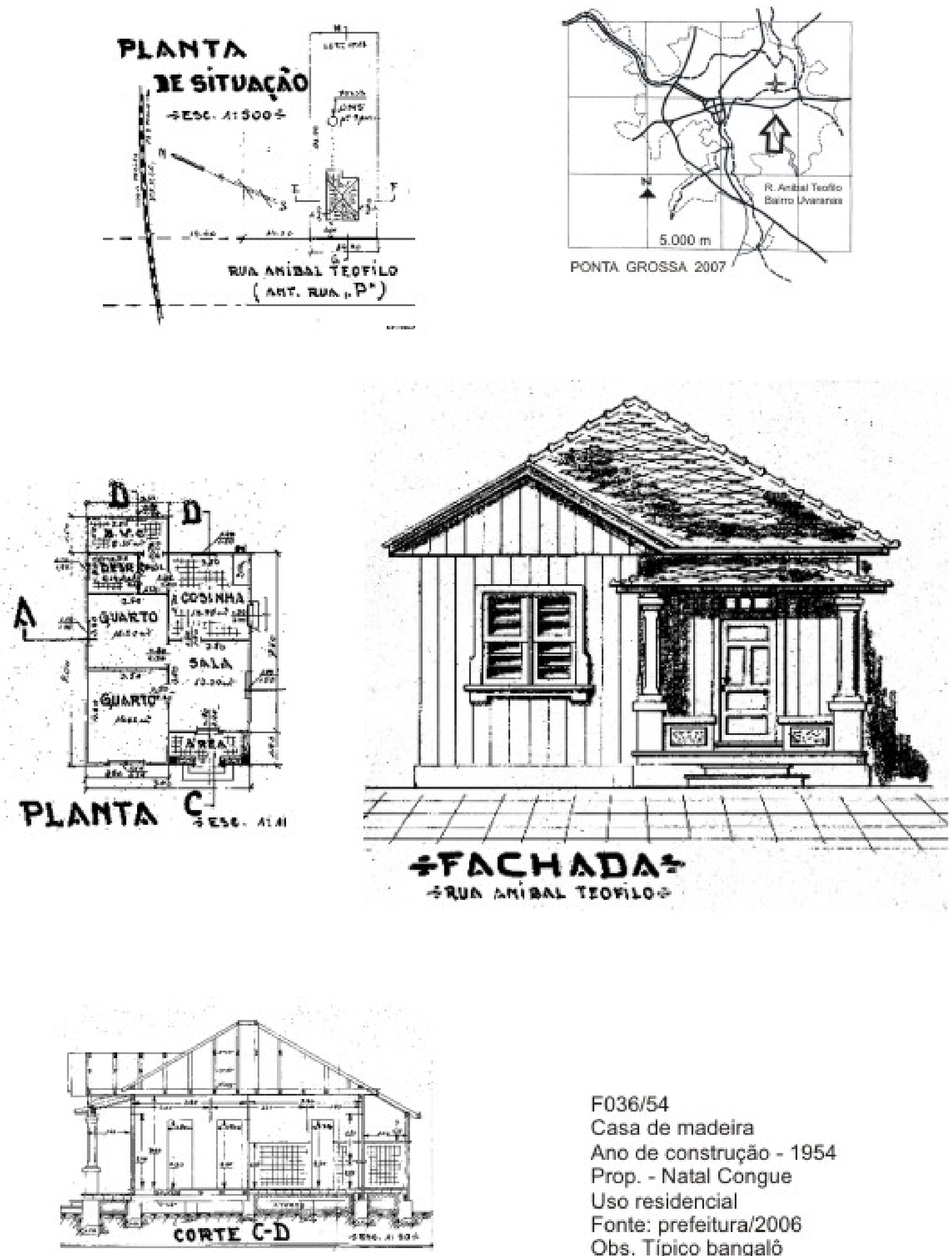

F036/54

Casa de madeira

Ano de construção - 1954

Prop. - Natal Congue

Uso residencial

Fonte: prefeitura/2006

Obs. Típico bangalô 

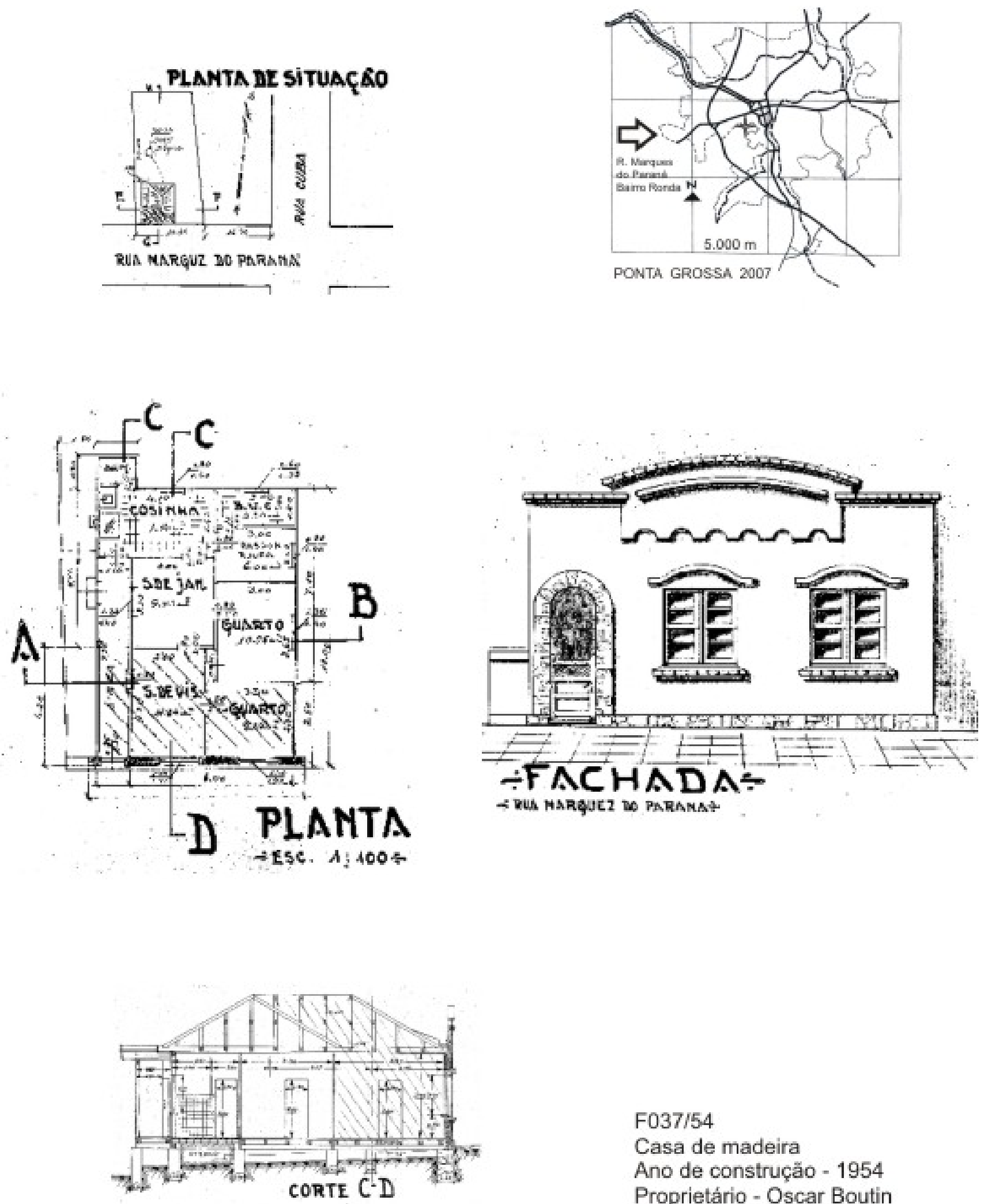

F037/54

Casa de madeira

Ano de construção - 1954

Proprietário - Oscar Boutin

Uso residencial

Fonte: prefeitura/2006

Obs. - fachada neocolonial 

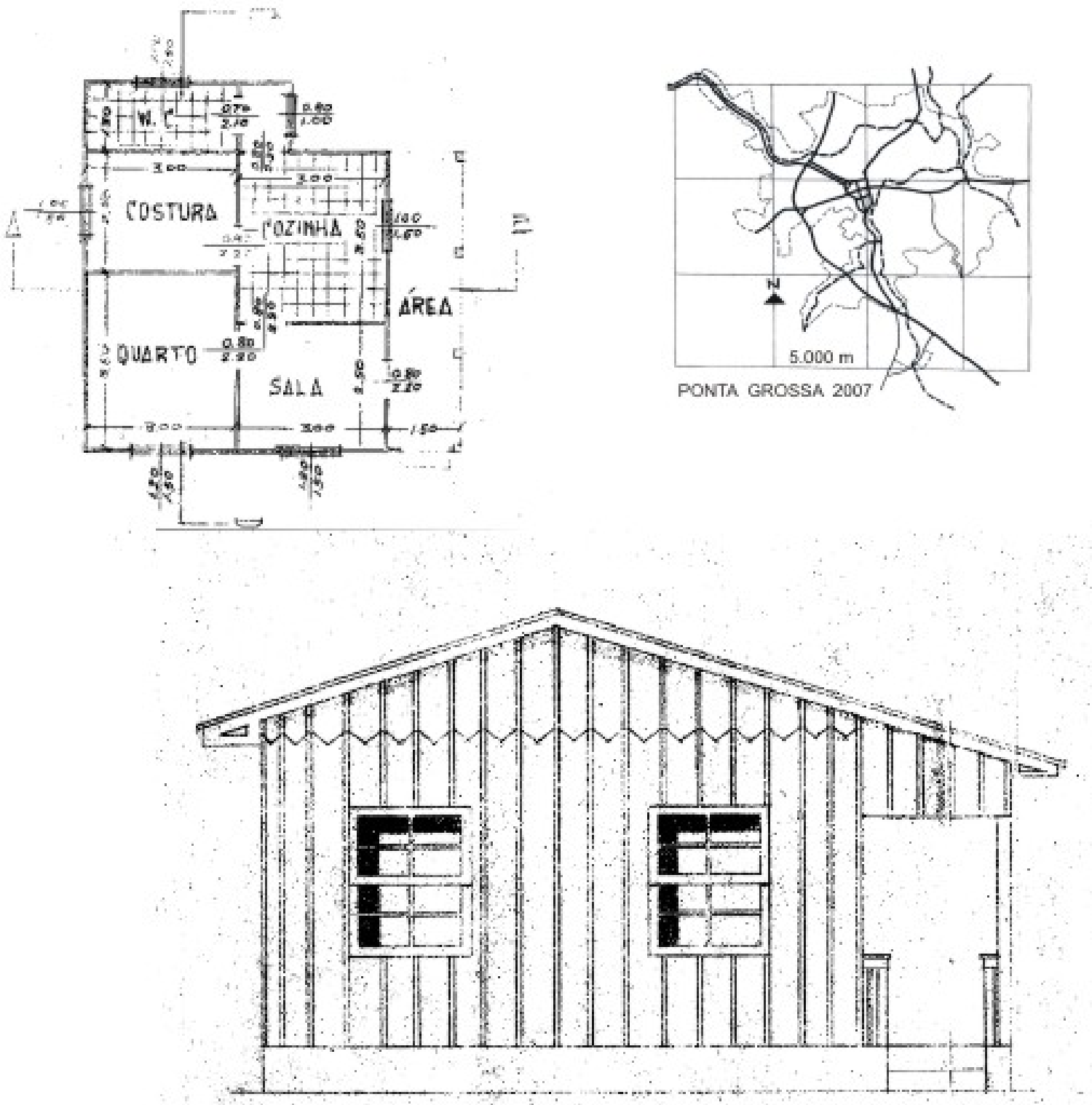

F $\triangle C H A D A \cdot 1: 50$

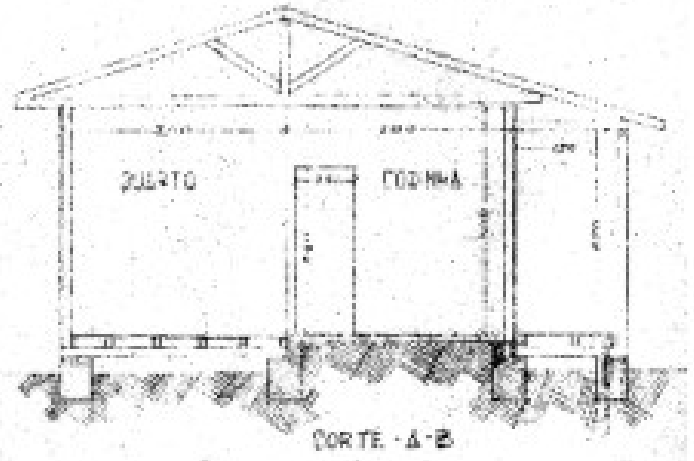

F039/54

Casa de madeira

Ano de construção - 1954

Prop. - Otávio Mato

Uso residencial

Fonte: prefeitura/2006 

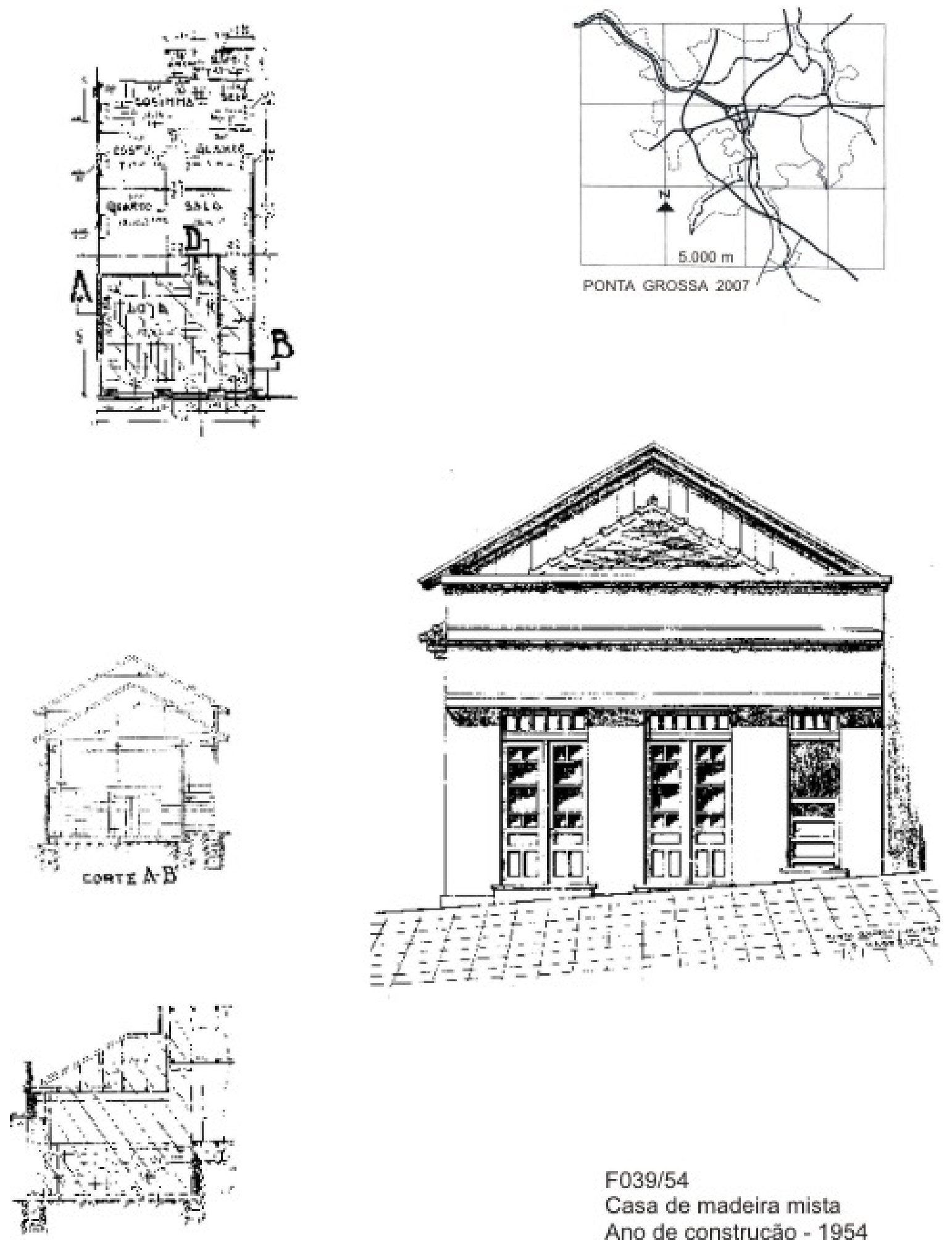

F039/54

Casa de madeira mista Ano de construçäo - 1954

Prop. - Paulino Schautz

Uso residencial e comercial Fonte: prefeitura/2006

Obs.- Ampliaçäo frontal com fachada eclética 


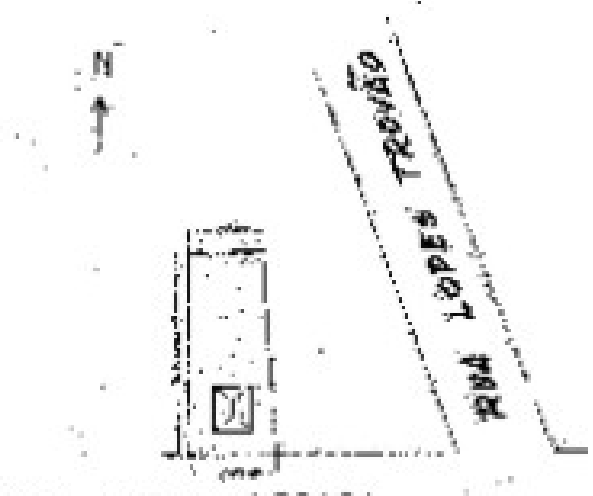

MUA MDEAL MOBAEGA
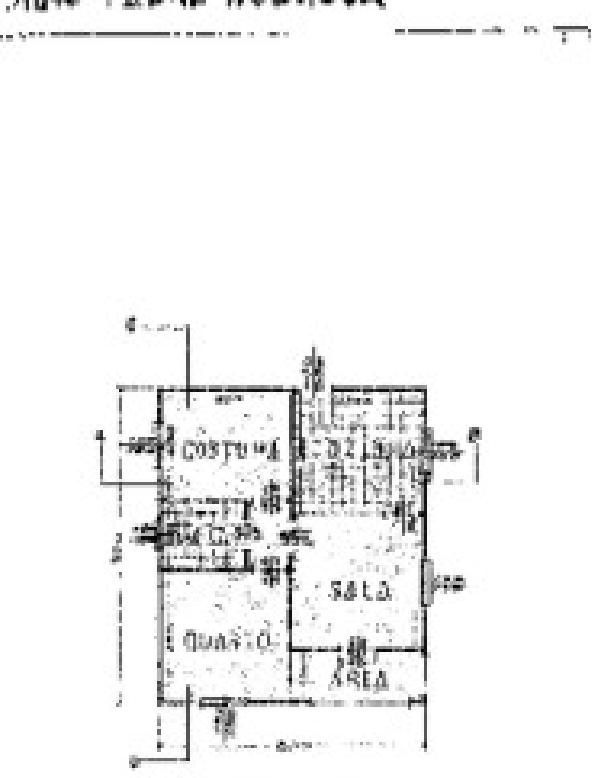

PLANTS. A-ICS

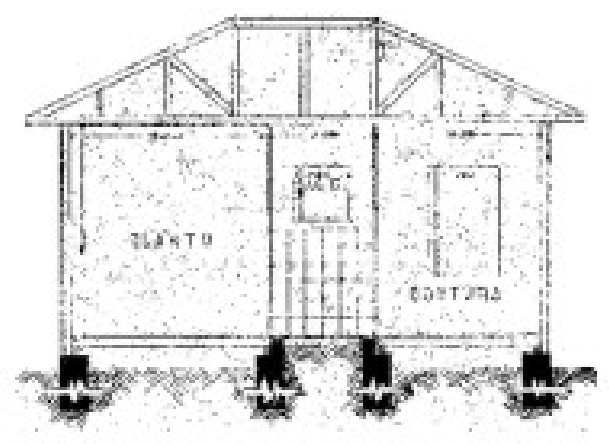

F041/54

Casa de madeira

Ano de construção - 1954

Prop. - Pedro Chepak

Uso residencial

Fonte: prefeitura/2006 

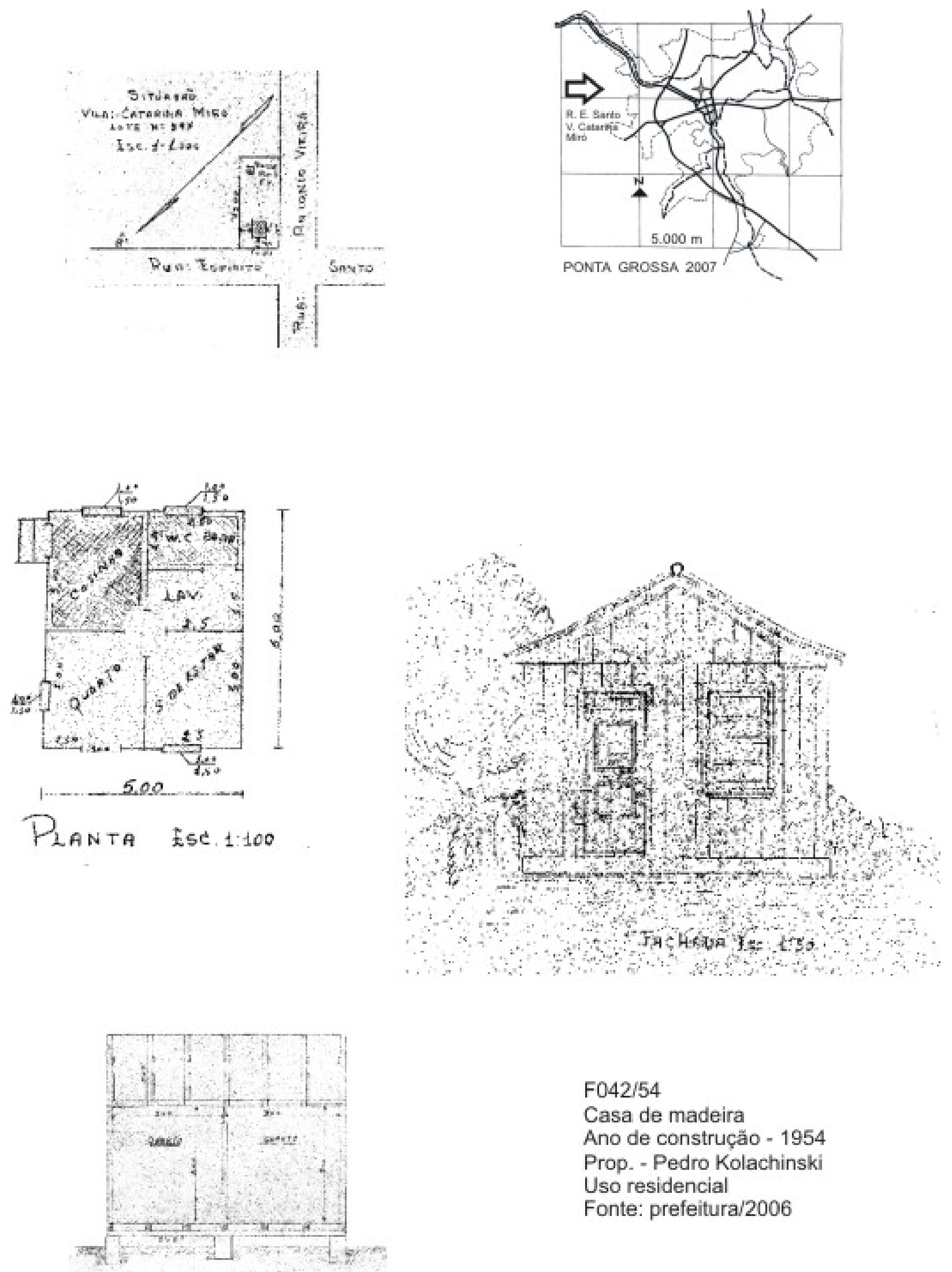

F042/54

Casa de madeira

Ano de construção - 1954

Prop. - Pedro Kolachinski

Uso residencial

Fonte: prefeitura/2006 

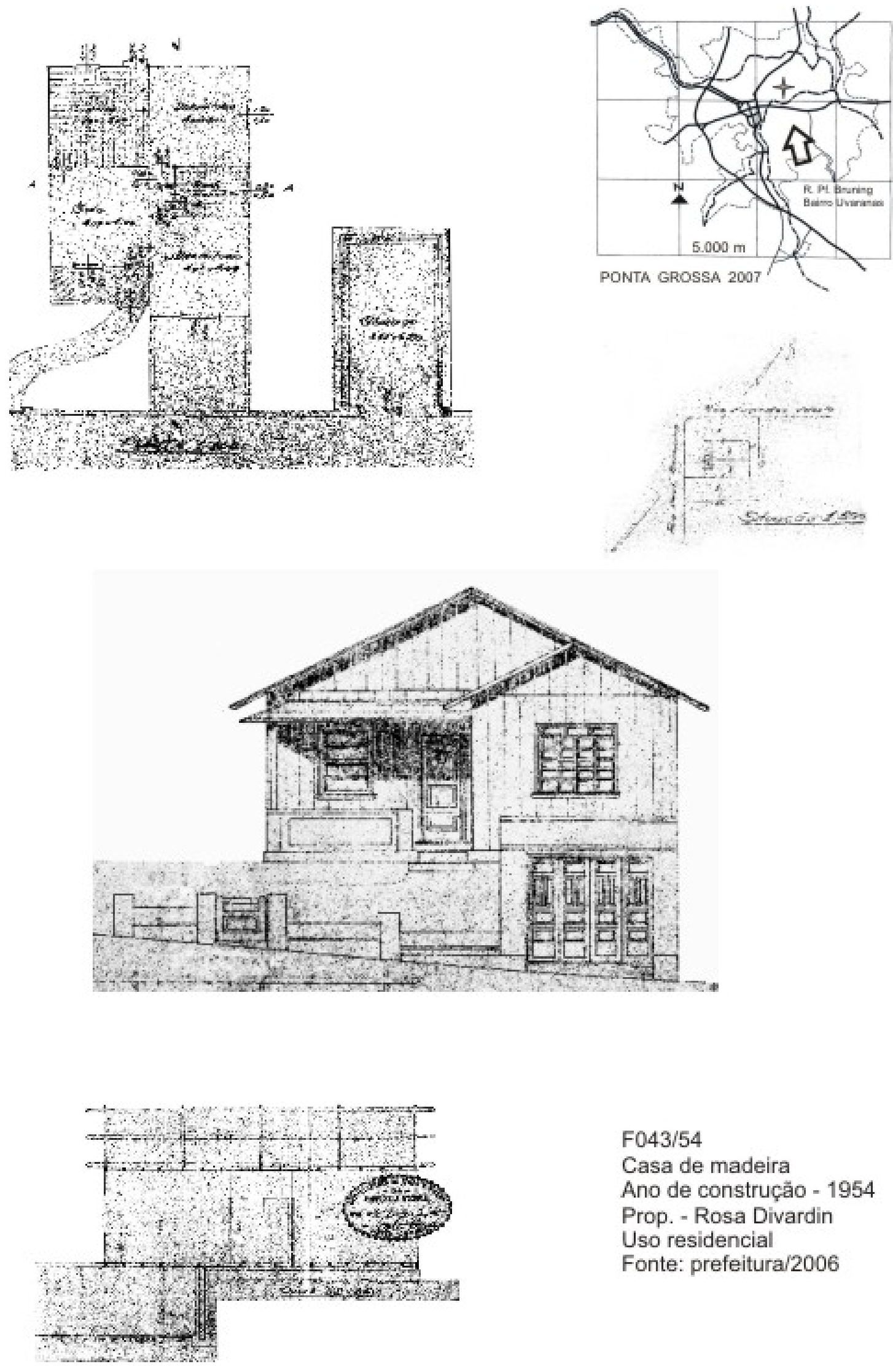

\section{F043/54}

Casa de madeira

Ano de construçăo - 1954

Prop. - Rosa Divardin

Uso residencial

Fonte: prefeitura/2006 

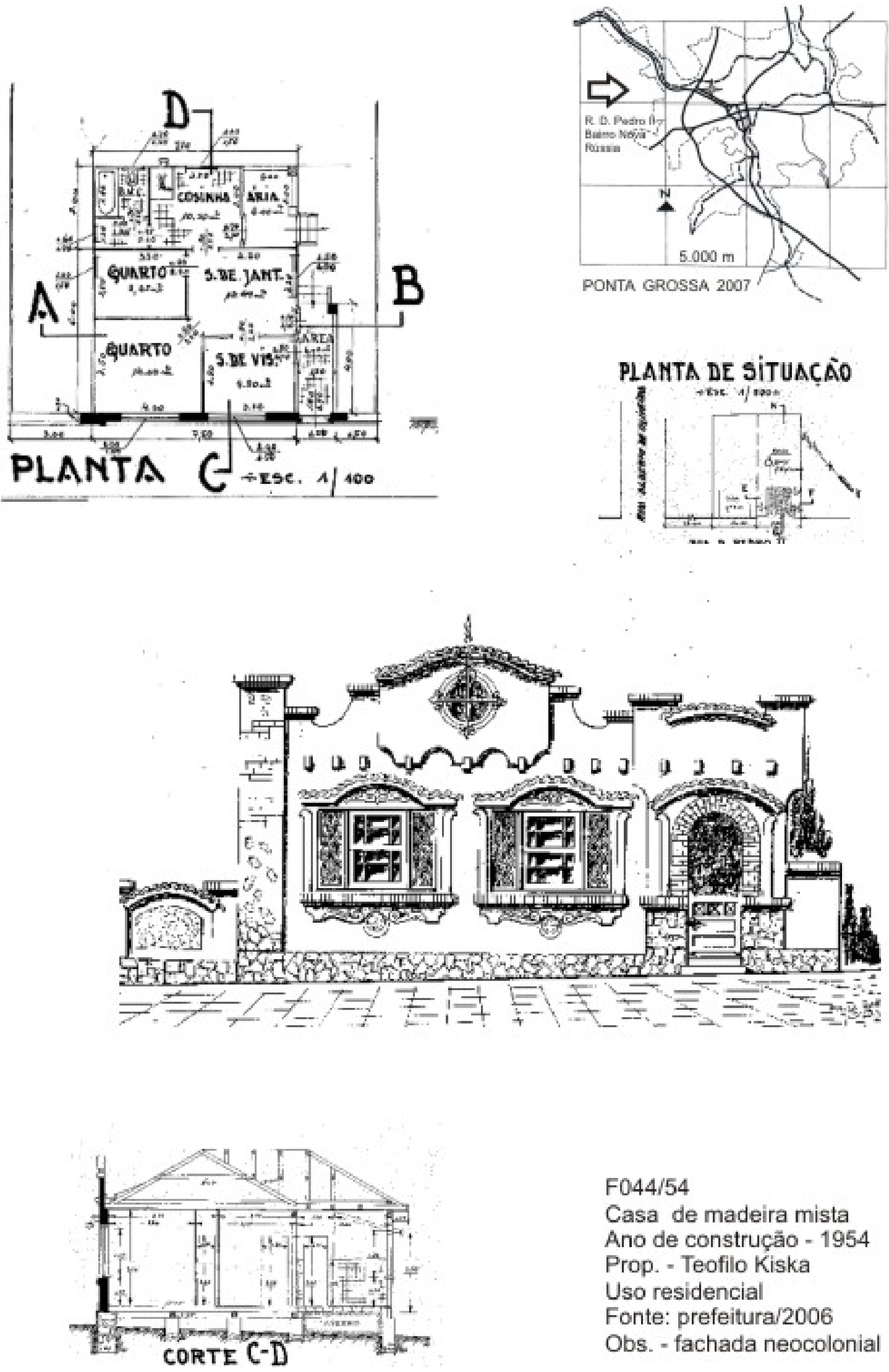

F044/54

Casa de madeira mista Ano de construçäo - 1954

Prop. - Teofilo Kiska

Uso residencial

Fonte: prefeitura/2006

Obs. - fachada neocolonial 

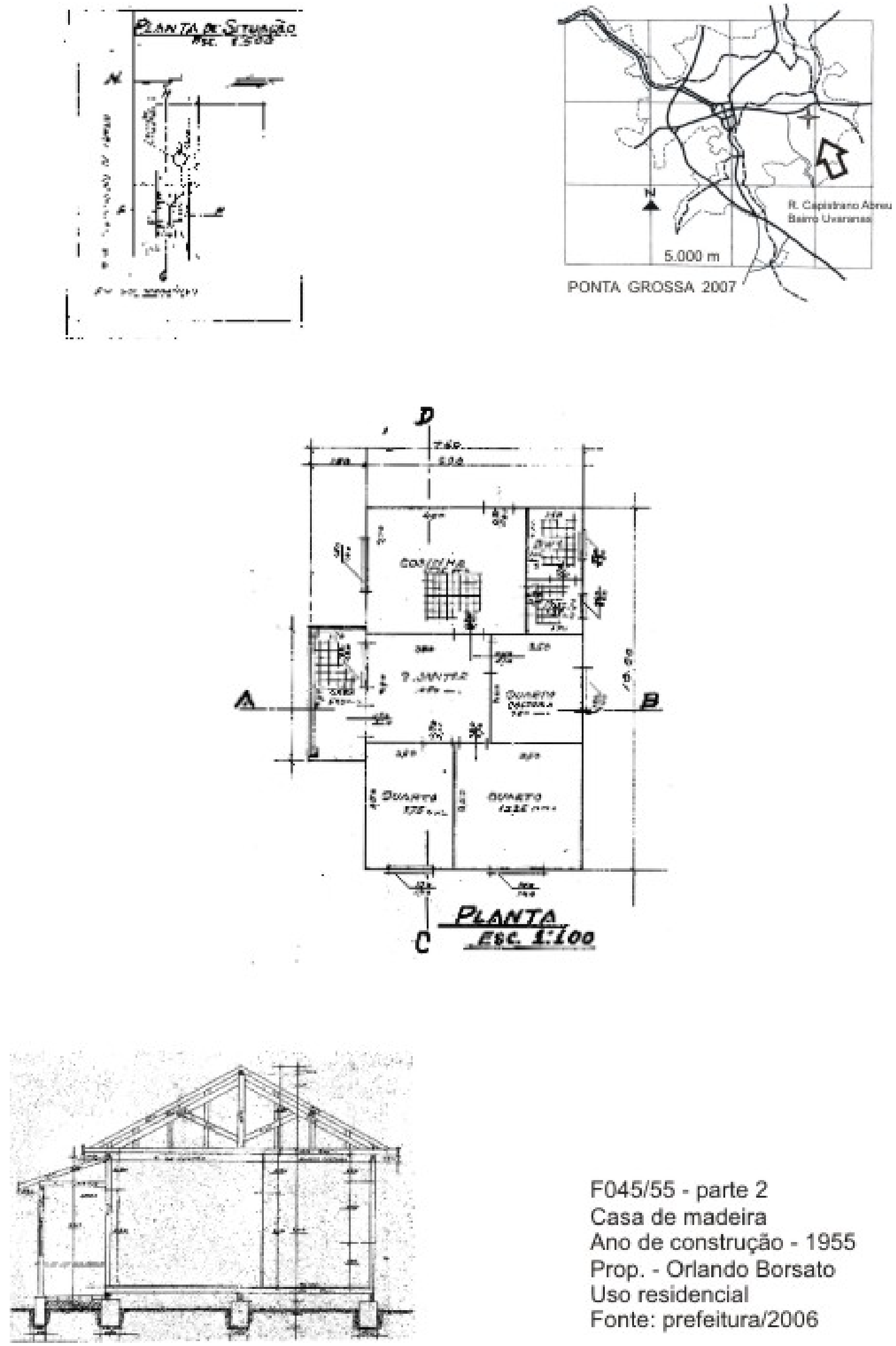

F045/55 - parte 2

Casa de madeira

Ano de construçăo - 1955

Prop. - Orlando Borsato

Uso residencial

Fonte: prefeitura/2006 

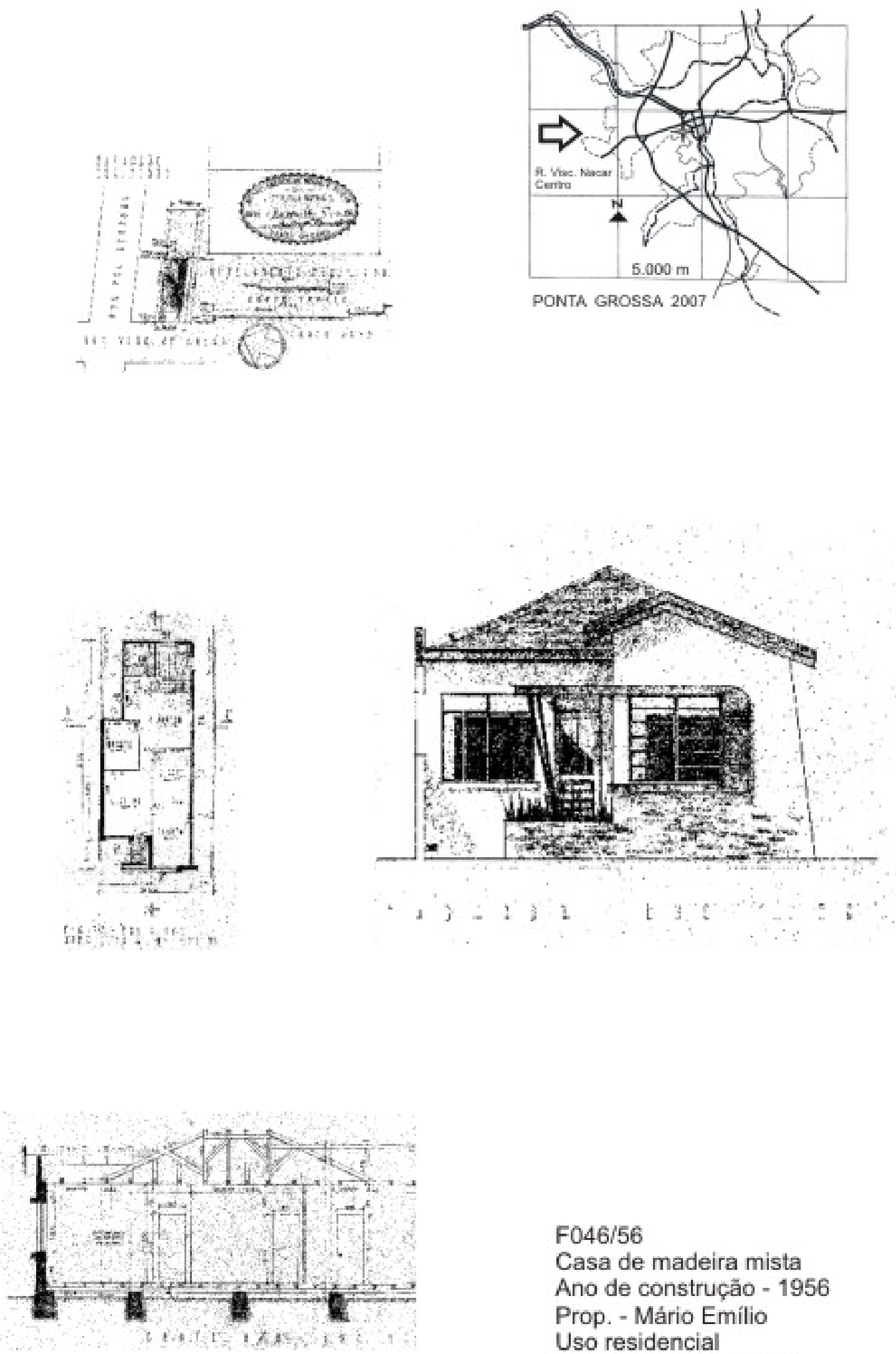

F046/56

Casa de madeira mista

Ano de construçăo - 1956

Prop. - Mário Emílio

Uso residencial

Fonte: prefeitura/2006 

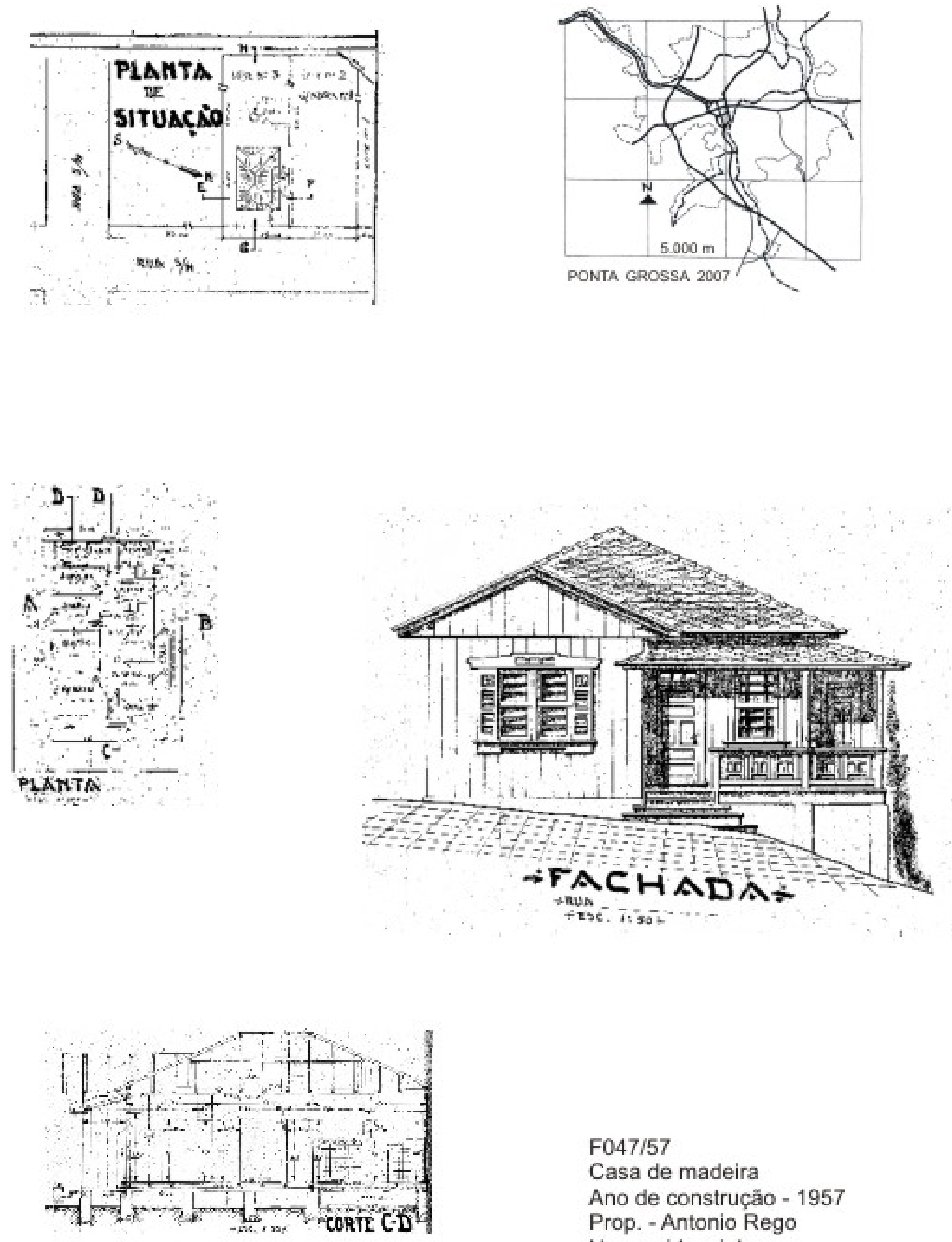

F047/57

Casa de madeira

Ano de construçăo - 1957

Prop. - Antonio Rego

Uso residencial

Fonte: prefeitura/2006

Obs. - típico bangalô 

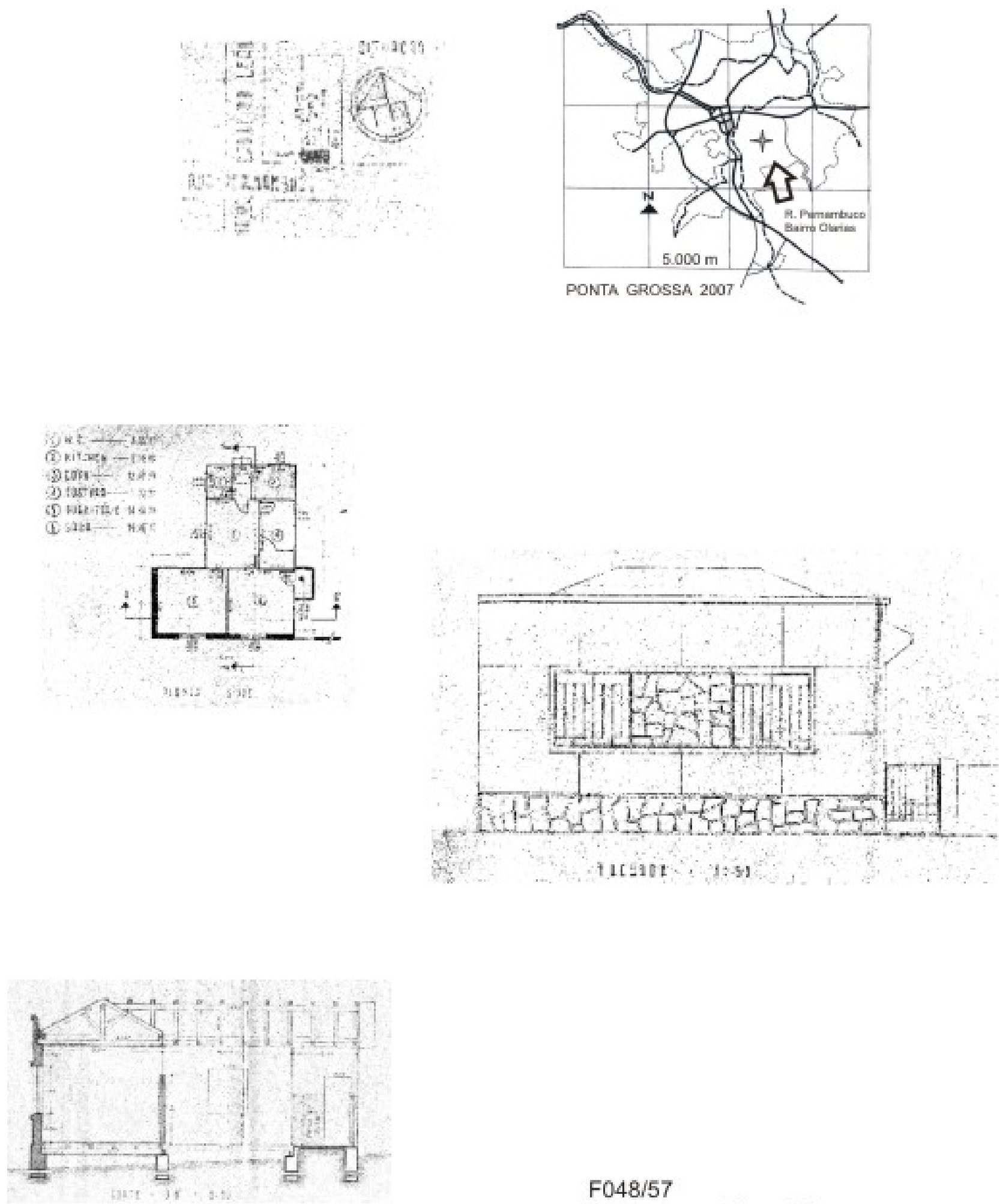

F048/57

Casa de madeira mista

Ano de construçăo - 1957

Prop. - Claudio lanchuki

Uso residencial

Fonte: prefeitura/2006 

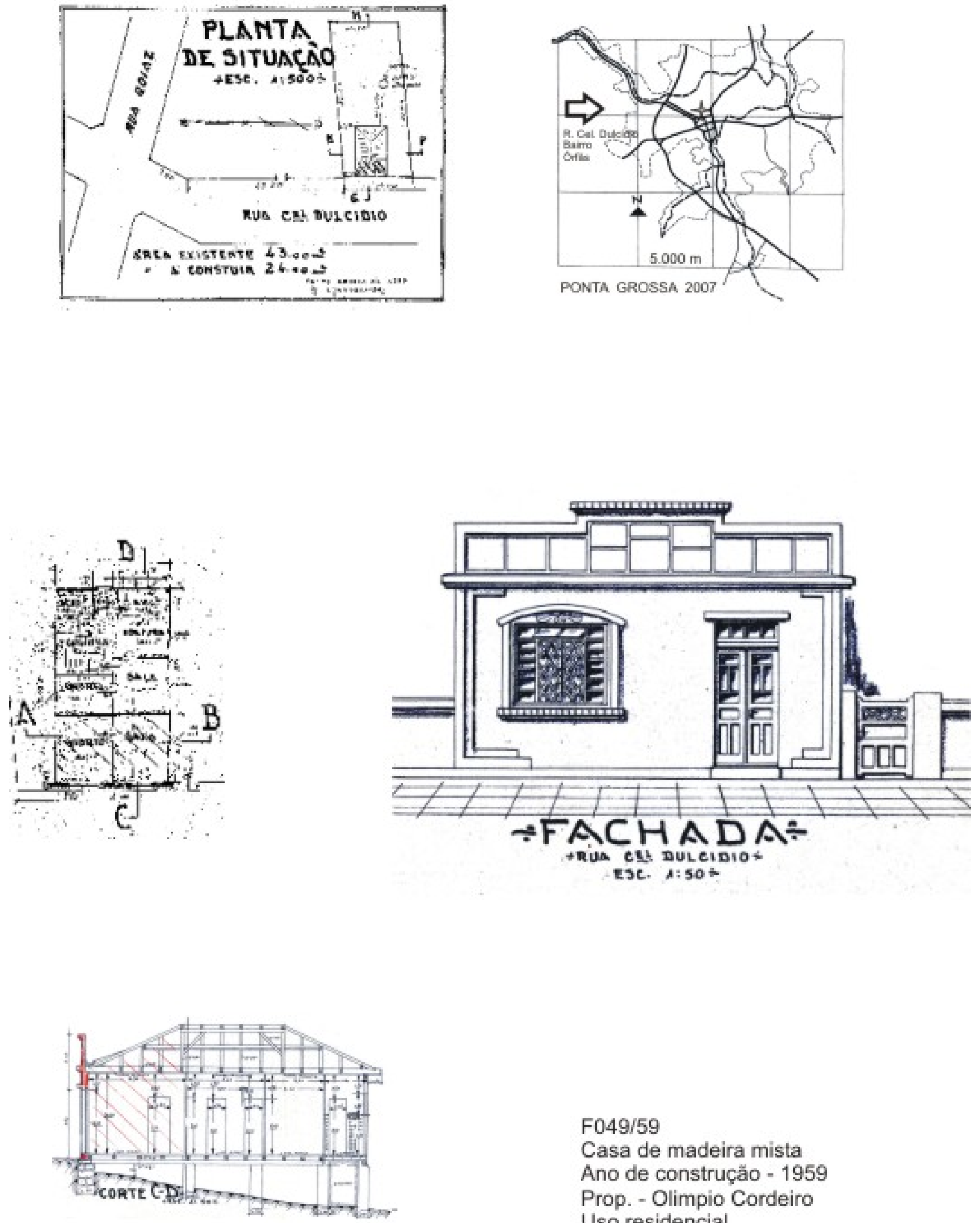

F049/59

Casa de madeira mista

Ano de construção - 1959

Prop. - Olimpio Cordeiro

Uso residencial

Fonte: prefeitura/2006 
Capítulo 6

LEVANTAMENTO DE EXEMPLARES DE CASAS DE MADEIRA EXISTENTES NA CIDADE DE PÓNTA GROSSA NO ANO DE 2006 


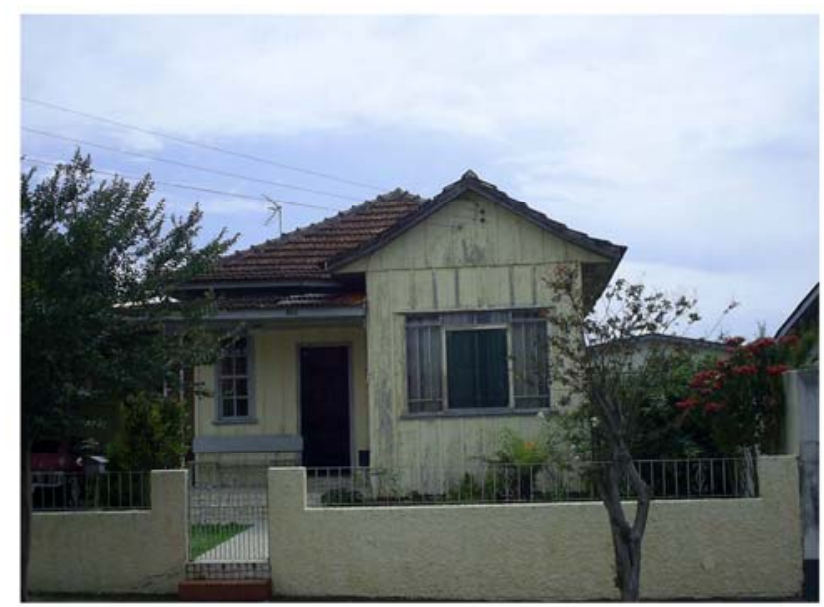

foto AK 2006

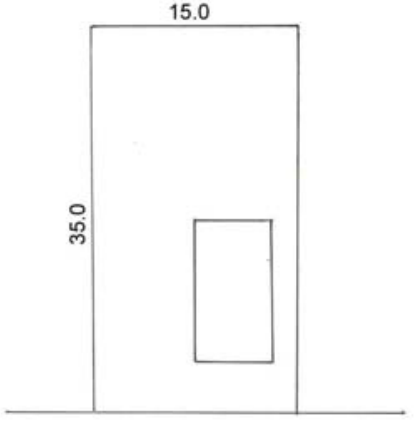

RUA FREIRE ALEMÃO, 440 OFICINAS

SITUAÇÃO

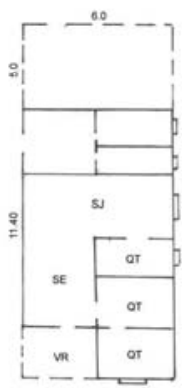

PLANTA

PROPRIETÁRIO - ALEXANDRE PAITCH ANO DE CONSTRUÇÃO - 1952 


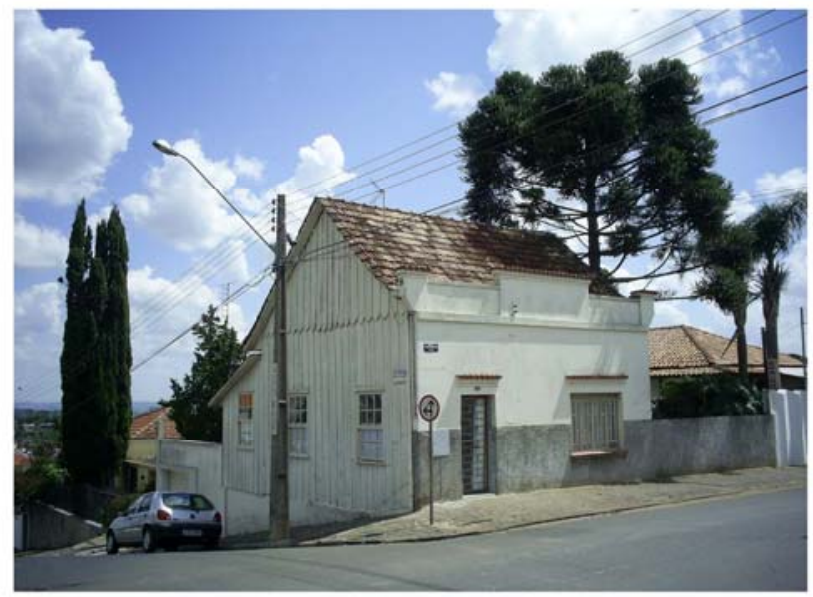

foto AK 2006

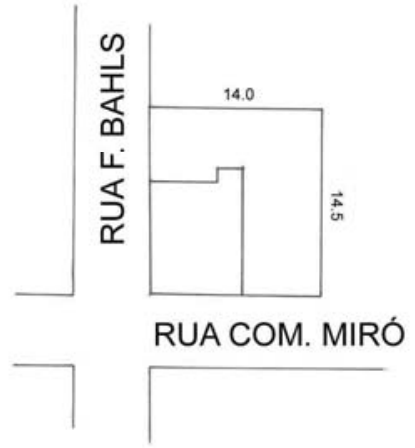

SITUAÇÃO

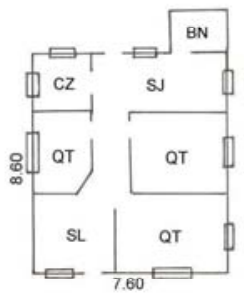

PLANTA

PROPRIETÁRIO - ALICE LEPKA RIBEIRO

ANO DE CONSTRUÇÃO - INÍCIO SÉC. 20 


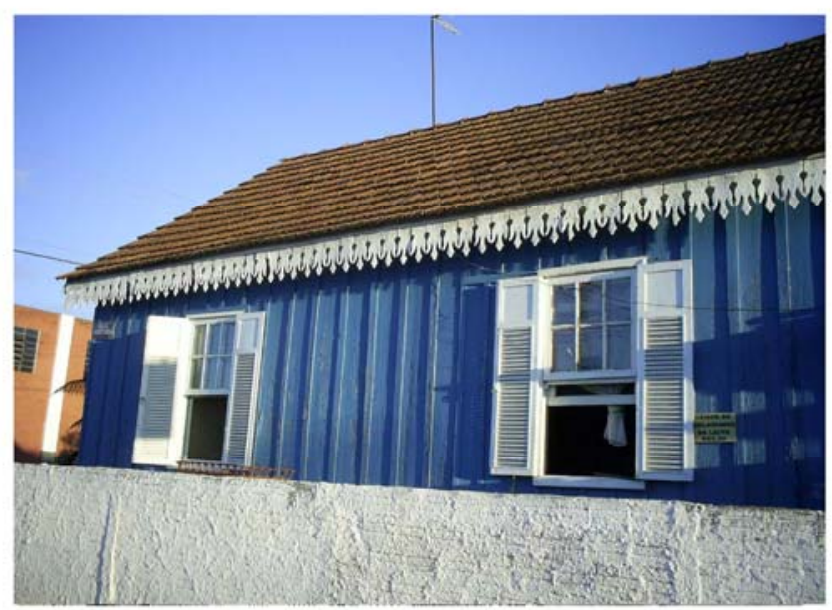

foto AK 2006
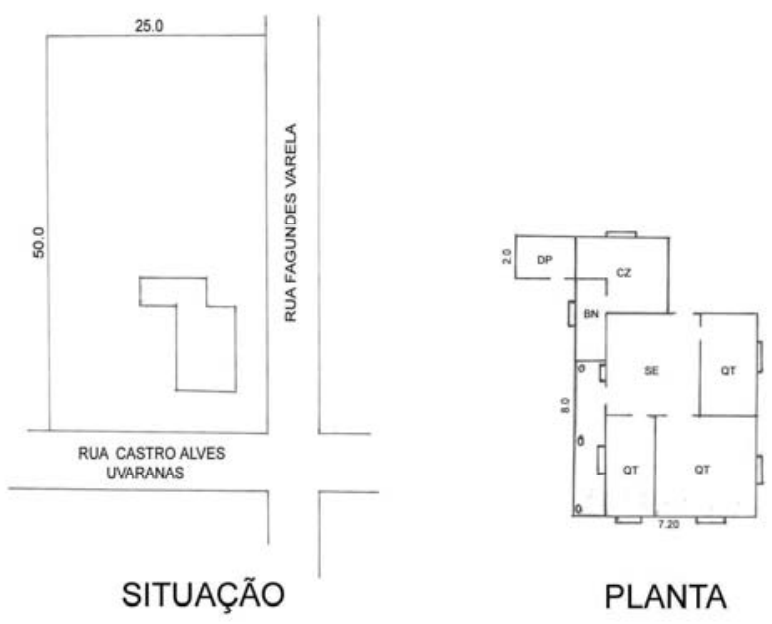

PLANTA

PROPRIETÁRIO - ANDRÉ FERREIRA

ANO DE CONSTRUÇÃO - 1937

LEVANTAMENTO DAS CASAS DE MADEIRA DE PONTA GROSSA - PARANÁ- 2006 


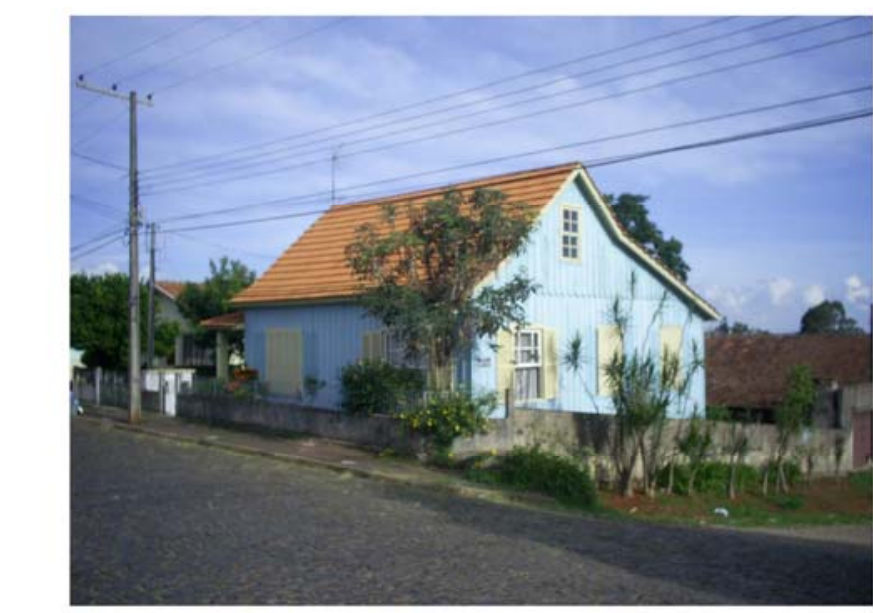

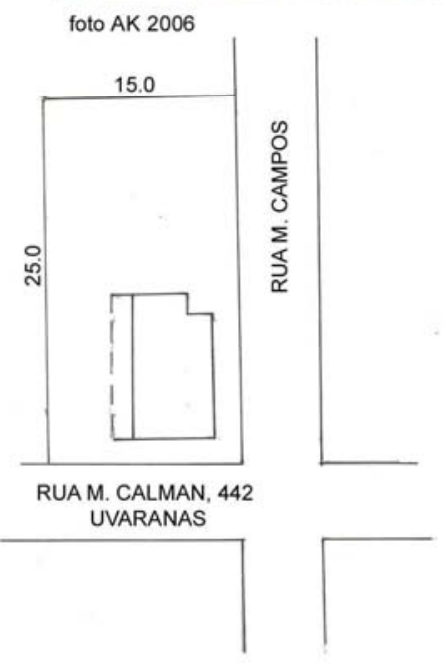

SITUAÇÃO
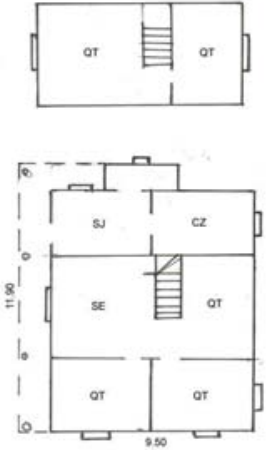

PLANTA

PROPRIETÁRIO - CLEMENTE DE BORTOLI ANO DE CONSTRUÇÃO - 1925

OBS. - CASA DE CHÂCARA 


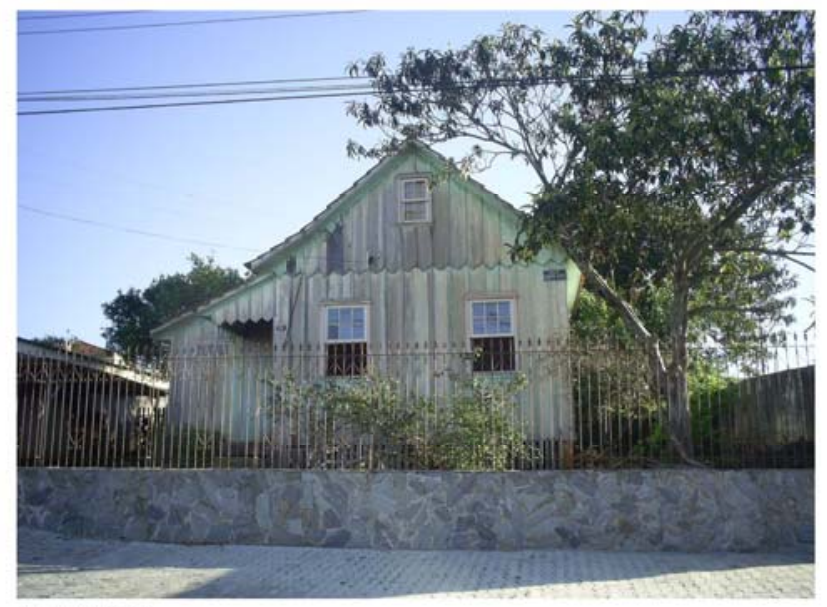

foto AK 2006
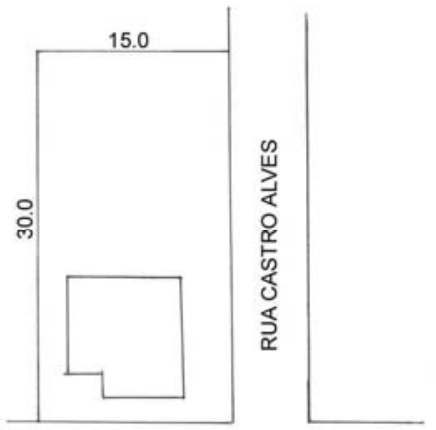

RUA XV DE SETEMBRO

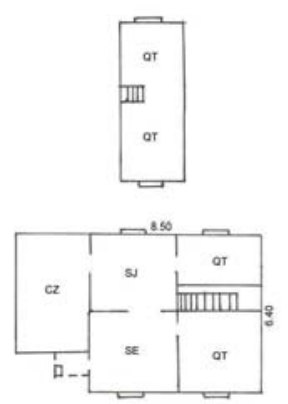

SITUAÇÃO

PLANTA

PROPRIETÁRIO - ESTEVÃO GONÇALVES ANO DE CONSTRUÇÃO - 1942 


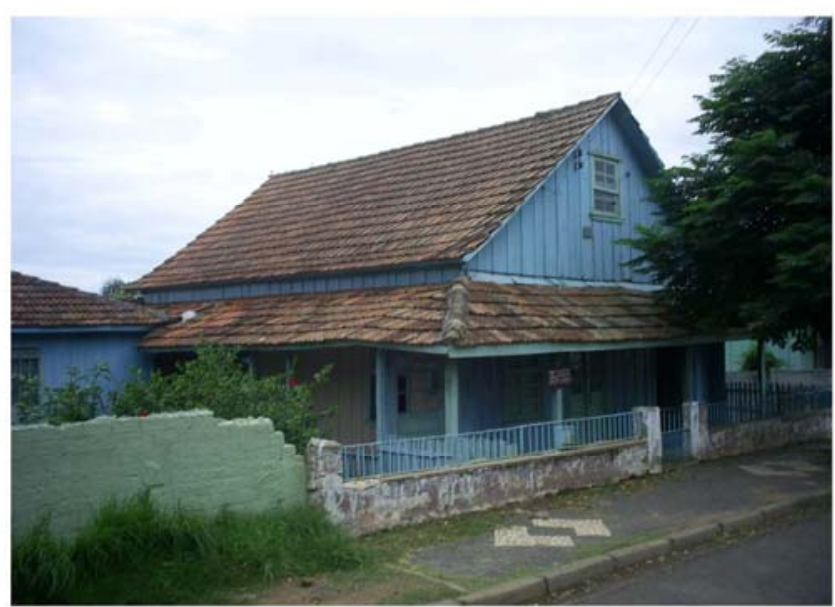

foto AK 2006

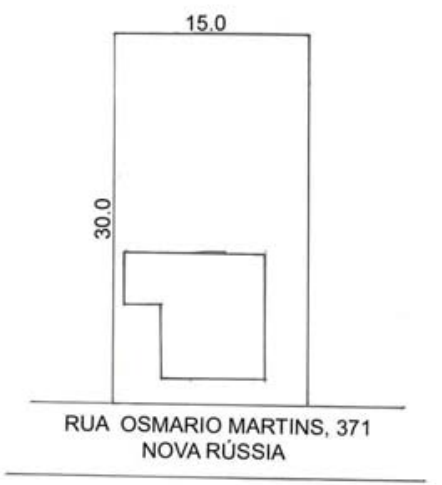

SITUAÇÃO
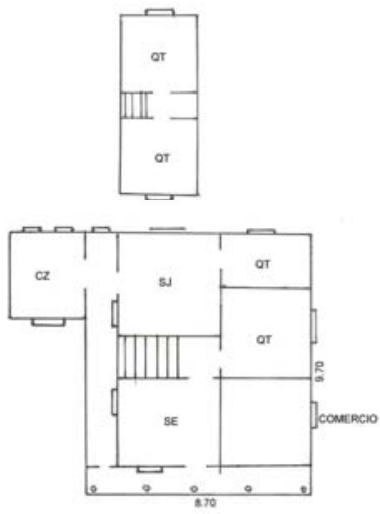

PLANTA

PROPRIETÁRIO - FRANCISCO ASTUFKA

ANO DE CONSTRUÇÃO - 1922 


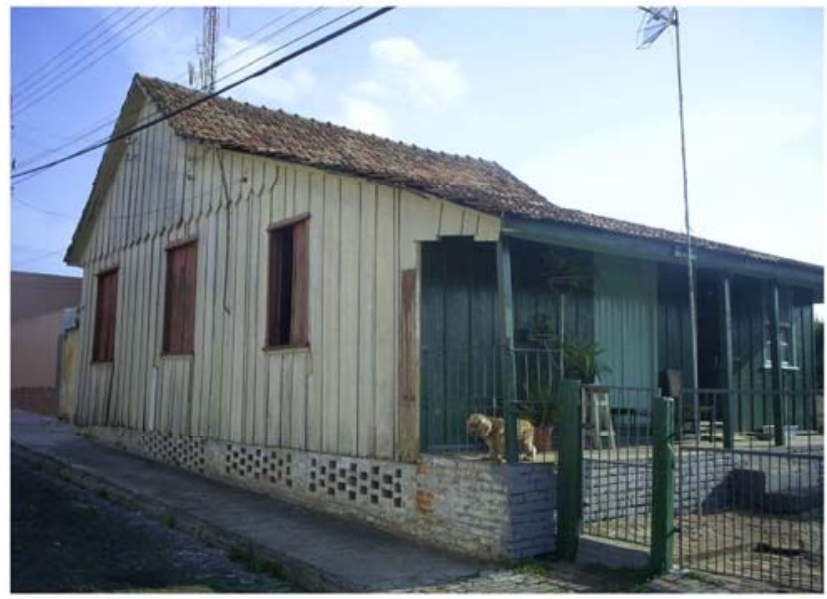

foto AK 2006
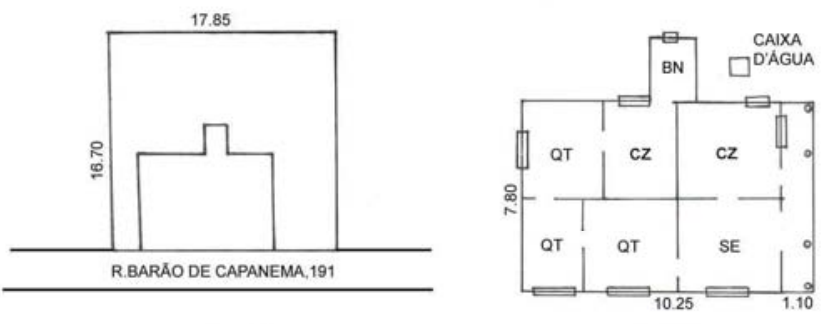

SITUAÇÃO

PLANTA

PROPRIETÁRIO - LUIZ GALVÃO

ANO DE CONSTRUÇÃO - S.D. 


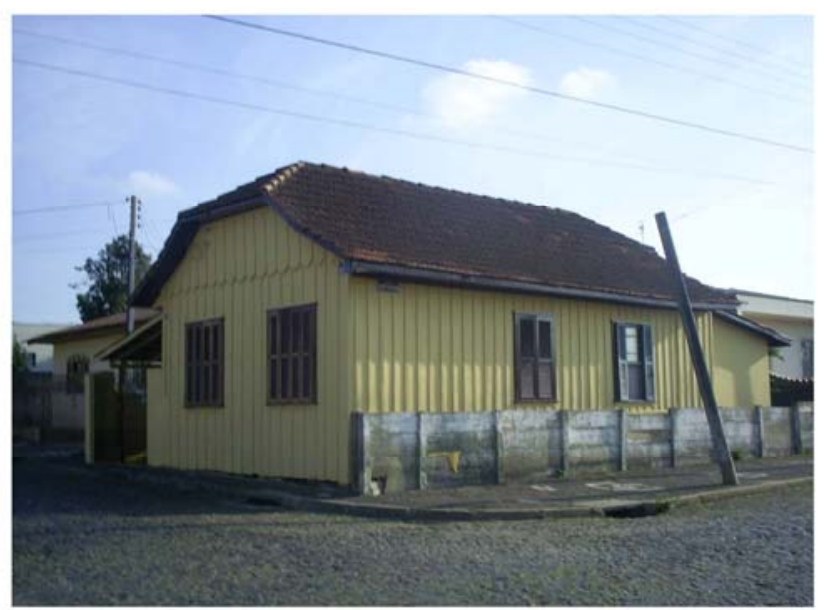

foto AK 2006

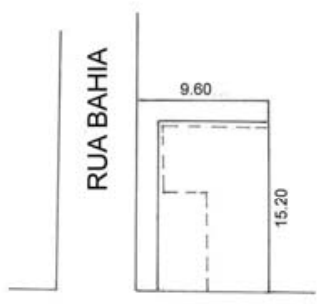

RUA COUTO MAGALHÃES
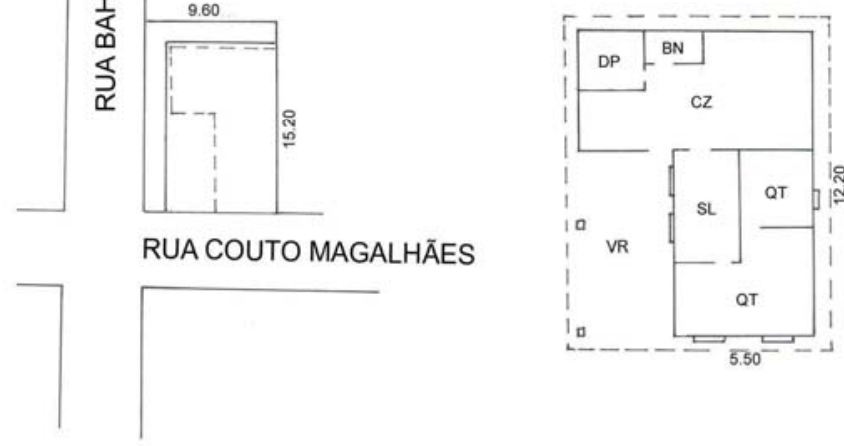

SITUAÇÃO

PLANTA

PROPRIETÁRIO - MARIA ALVEZ SANTOS ANO DE CONSTRUÇÃO - S.D. 


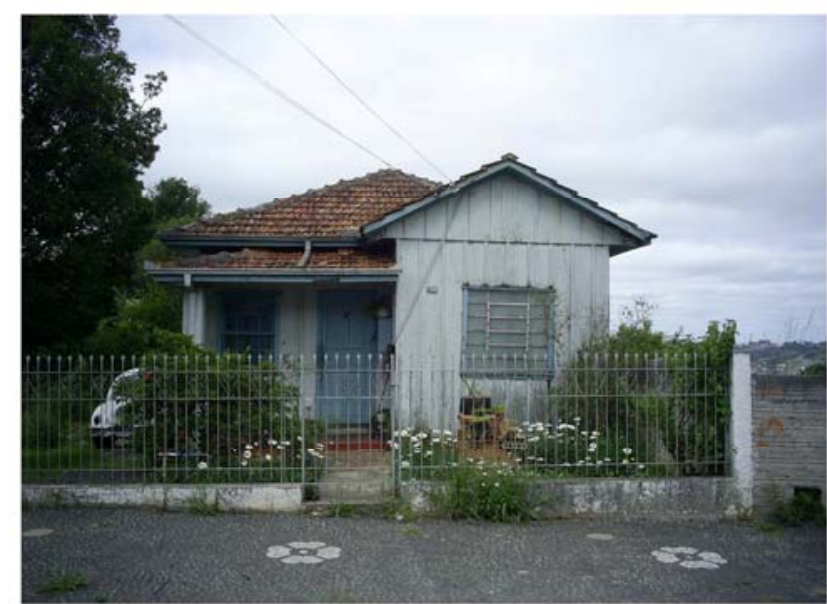

foto AK 2006

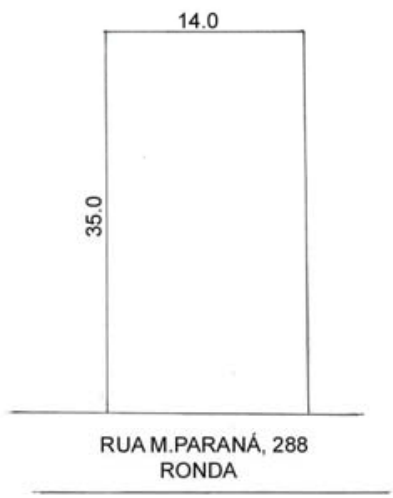

SITUAÇÃO

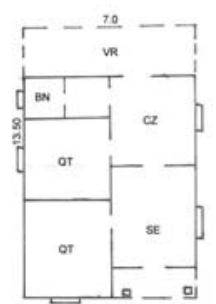

PLANTA

PROPRIETÁRIO - MARIA PAVOSKI

ANO DE CONSTRUÇÃO - 1959 


\section{BIBLIOGRAFIA}

Brazil, South in: Encyclopédia of Vernacular Architecture of the World. Ed. Paul Oliver, Un. Cambridge. 1977.

IMAGUIRE Jr., Key. A Arquitetura no Paraná: Uma Contribuição Metodológica para a História da Arte. Dissertação de Mestrado. UFPr. Curitiba. 1982.

- A Casa de Araucária - Arquitetura Paranista.Tese de Concurso para Professor Titular do Curso de Arquitetura da UFPr. Curitiba. 1982.

SANCHEZ, Fernanda et alli - Arquitetura em madeira - uma tradição paranaense. Curitiba. Ed. UFPr. 1987

VALENTINI, Jussara. A Arquitetura do Imigrante Polonês na Região de Curitiba. Curitiba. Instituto Histórico Geográfico e Etnográfico Paranaense. 1982.

MIRANDA, Nego et alii. Igrejas de Madeira do Paraná. Curitiba. Edição do autor. 2005.

ZANI, Antonio Carlos. Arquitetura de madeira: reconhecimento de uma cultura arquitetônica norteparanaense. Tese de doutorado na FAU/USP. São Paulo. 1997.

CLARO, Anderson. A produção de casas de madeira em Santa Catarina. Dissertação de mestrado na FAU/USP. São Paulo. 1991.

BARBOSA, Gino Caldatto. Chalé de Madeira. A moradia popular de Santos. Dissertação de mestrado na FAU/USP. São Paulo. 1998.

BARBOSA, Ney Caldatto. Arquitetura vernácula latino-americana. Dissertação de Mestrado na FAU/USP. São Paulo. 1999.

WEIMER, Gunter. A arquitetura. Porto Alegre. Editora UFRGS. 1992.

Architettura e Societá - América Latina nel XX sécolo. Enciclopédia Temática Aperta Grande Voici. Milão. Ed. Jaca Book. 1996.

SUTIL, Marcelo Saldanha. O espelho e a miragem: ecletismo, moradia e modernidade na Curitiba do início do século. Dissertação de mestrado na UFPr. Curitiba. 1996.

. Um Olhar para o futuro. Curitiba. Boletim da Casa Romário Martins. 2005. 
WOLF, Sílvia Ferreira Santos. Jardim América. São Paulo. Edusp. 2001.

CIFFONI, Ana Lúcia et alli. Centro Histórico. Espaços do passado e do presente. Curitiba. Boletim da Casa Romário Martins. 2006.

CHAVES, Niltonci Batista - org. - Visões de Ponta Grossa. Ponta Grossa - Livros1, 2 e 3. UEPG. 2001.

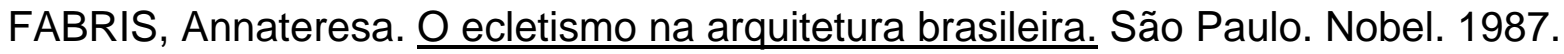

LEMOS, Carlos. Alvenaria Burguesa. São Paulo. Nobel. 1989.

- Arquitetura Brasileira. São Paulo. Melhoramentos. 1979.

SAIA, Luís. Morada Paulista. São Paulo. Perspectiva. 1972.

- Notas sobre a evolução da morada paulista. São Paulo. Acróple. 1957.

FREYRE, Gilberto. A casa brasileira. Rio de Janeiro. Grifo Edições. 1970.

SANTOS, Paulo Ferreira. Quatro séculos de arquitetura. Rio de Janeiro. Fundação Educacional Rosemar Pimentel. 1977.

SEGAWA, Hugo. Arquiteturas no Brasil. São Paulo. Edusp. 1999. 1981.

BRUAND, Yves. Arquitetura Contemporânea no Brasil. São Paulo. Ed. Perspectiva.

SEGRE, Roberto. América Latina: Fim de milênio. Raízes e perspectivas de sua arquitetura. São Paulo. Studio Nobel. 1991.

REIS FILHO, Nestor Goulart. Quadro da arquitetura no Brasil. São Paulo. Perspectiva. 1983.

- O Lote Urbano e a arquitetura no Brasil. São Paulo. FAU/USP. 1969.

- Evolução urbana do Brasil. São Paulo. Livraria Pioneira. Sd

COSTA, Lúcio et alli. Documentação Necessária, in: Arquitetura Civil I, II, e III, Revista do Patrimônio Histórico e Artístico Nacional. São Paulo. FAU/USP. 1975. 
ROTH, Leland. Entender la arquitectura. Barcelona. Gustavo Gilli. 1993.

DUDEQUE, Irã Taborda. Espirais de Madeira - uma história da arquitetura de Curitiba. São Paulo. Studio Nobel. 2001.

GNOATO, Luís Salvador Petrucci. Arquitetura e urbanismo de Curitiba. Tese de doutorado na FAU/USP. São Paulo. 2002. 